\title{
Hydrologic Consequences of
}

Hot-Rock/Snowpack Interactions at

Mount St. Helens Volcano, Washington, 1982-84

THOMAS C. PIERSON, Editor

U.S. GEOLOGICAL SURVEY OPEN-FILE REPOR'T 96-179

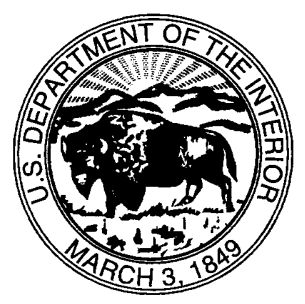




\title{
DEPARTMENT OF THE INTERIOR
}

\author{
BRUCE BABBIT, Secretary
}

U.S. GEOLOGICAL SURVEY

Gordon P. EaTon, Director

For sale by

U.S. Geological Survey, Information Services

Federal Center, Box 25286,

Denver, CO 80225

The report is also available in digital form through the World Wide Web URL: http://vulcan.wr.usgs.gov/Volcanoes/

Any use of trade names in this publication is for descriptive purposes only and does not imply endorsement by the U.S. Geological Survey

Graphics and manuscript layout by Christine Janda 


\section{CONTENTS}

Introduction

1

Thomas C. Pierson and Richard B. Waitt

1. Nature of Depositional Contacts between Pyroclastic Deposits and Snow or Ice

Joseph S. Walder

2. Transformation of Water Flood to Debris Flow following the Eruption-Triggered Transient-Lake Breakout from the Crater on March 19, 1982

Thomas C. Pierson

3. Sediment Transport in the Hyperconcentrated Phase of the March 19, 1982, Lahar Randal L. Dinehart

4. Dome-Collapse Rockslide and Multiple Sediment-Water Flows Generated by a Small Explosive Eruption on

February 2-3, 1983 53

Thomas C. Pierson and Richard B. Waitt

5. Rock Avalanches, Rockfalls, and Associated Processes Induced by Spreading of the Lava Dome, March 1984 Jon J. Major and Patrick T. Pringle

6. Eruption-Triggered Lahar on May 14, 1984 Patrick T. Pringle and Kenneth A. Cameron

\section{Appendixes}

1.A

1.B 


\section{CONTENTS}

\section{ILLUSTRATIONS}

\section{INTRODUCTION}

FIGURE 1. Photograph showing bombardment of slopes of Sakurajima volcano with incandescent rock fragments during nighttime

2. Photograph showing pyroclastic surges descending snow- and ash-covered slopes of the south sector of Mount St. Helens at a velocity of about 50 meters per second during first moments of the May 18, 1980, explosive eruption

3. Photograph showing small rockslide-avalanche in progress from Mount St. Helens lava dome, June 10, 1985

4. Photograph showing lobe of rock avalanche deposit showing thorough mixing of rock debris and snow .

5. Location map of Mount St. Helens area showing major streams draining the volcano .......... 6

6. Photograph showing snow-covered lava dome and crater of Mount St. Helens on March 7, 1985

7. Map of Mount St. Helens crater and Pumice Plain, which acts as head of the North Fork Toutle River

\section{CHAPTER 1}

FIGURE $\quad 1.1$ Photograph showing pyroclastic deposits lying on snow; Mount St. Helens, Washington ..... 10

1.2 Photograph showing pyroclastic deposits lying on snow; Redoubt Volcano, Alaska ............. 11

1.3 Schematic cross section through a pyroclastic deposit of mean thickness $L$ overlying snow and ice

1.4 Photograph showing results of experiment to illustrate differential melting on an irregular interface

1.5 Definition of coordinate system for Fourier-series description of step in contact between snow and overlying pyroclasts

1.6 Photograph showing ice-cemented mixed avalanche deposits on Drift Glacier, Redoubt

Volcano, Alaska

\section{CHAPTER 2}

FIGURE 2.1 Flow path of the March 19, 1982, eruption-triggered flood and subsequent debris flow

2.2 Position of highest transient-lake level, as interpreted from pumice-block strandlines and other shoreline features mapped from aerial photography of March 23, 1982.

2.3 Photograph showing view to the northeast out of the crater breach, where the water flood left the crater floor and entered the deeply incised ravines on the north flank

2.4 Photograph showing view into crater from head of Loowit Ravine

2.5 Photograph showing oblique aerial view (looking south) of the crater floor and breach, the eroded topography of the volcano's lower north flank (the Steps), and the head of the Pumice Plain (Step Fan) 


\section{ILLUSTRATIONS—Continued}

FIGURE 2.6 Longitudinal profile of flood flow path

$A$. On crater floor (from east spillway to head of Loowit Ravine) ................................. 26

$B$. Continuation of $A$ on north flank of the volcano (along axis of Loowit Ravine) ........ 26

2.7 Photograph of unit 1 debris-flow deposit at head of Pumice Plain, about 6 kilometers downstream from flood source ............................................................................. 27

2.8 Photograph showing lobe of Unit 2 debris-flow deposit at head of Pumice Plain ................. 27

2.9 Cumulative frequency curves of samples of debris-flow deposits (clasts larger than 64 millimeters not sampled) from upper North Fork Toutle River .....

2.10 Photograph showing thin (few centimeters thick) Unit 2 debris-flow deposit on lower

Pumice Plain; boulders stranded when finer-grained slurry continued flowing downstream

2.11 Photograph showing gullying left by erosion of 1980 pumiceous pyroclastic-flow deposits by debris flow on the lower Pumice Plain

2.12 Cross sections of North Fork Toutle River channel where it is cut into the 1980 debrisavalanche deposit at distances of about 13 and 20 kilometers downstream from the transient lake

2.13 Stratigraphic relations of Unit 1 to Unit 2 at distal end of channel reach carrying debris flow

\section{CHAPTER 3}

FIGURE 3.1 Course of the March 19, 1982 lahar past gaging stations on the Toutle River and Cowlitz River

3.2 Photograph of standing waves in the Toutle River upstream from the Highway 99 bridge ....

3.3 Photograph showing newly deposited sand at right side of Toutle River channel, as

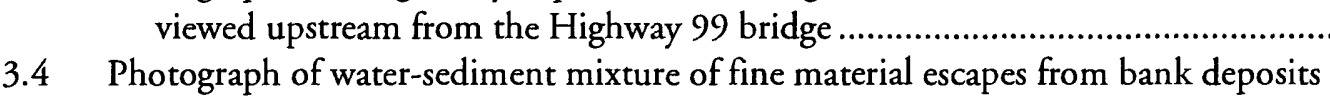
and returns to main flow.

3.5 Sediment concentration and stream discharge derived from measurements of the hyperconcentrated phase of the lahar at the Toutle River gaging stations.

3.6 Sediment concentration in two sand-size classes for the hyperconcentrated phase of the lahar, fit with an exponential recession curve

3.7 Sediment concentration of the lahar-generated flood wave measured at the gaging station at the Cowlitz River at Castle Rock

\section{CHAPTER 4}

FIGURE 4.1 Flow paths and deposits of sediment-water flows triggered by an explosive burst at Mount St. Helens on February 3, 1983 during a dome-building eruption

4.2 Photograph of southward oblique aerial view of crater, Loowit Ravine, and Pumice Plain on February 3, 1983, showing darkened, debris-covered east crater wall and path of mixed avalanche and succeeding flows

4.3 Seismograph records for parts of the 2339 (February 2, 1983) and the 0256 (February 3, 1983) eruptive bursts from seismic stations YEL and EDM

4.4 Photograph of northwestward view of dome on February 3, 1983, showing rockslide deposit and mixed-avalanche deposit on crater floor

4.5 Plan view of flow paths and deposits in crater and breach areas 


\section{ILLUSTRATIONS-Continued}

FIGURE 4.6 Photograph showing rough-surfaced mixed-avalanche deposit, 80 centimeters thick, overlying snow in lower crater breach at head of Loowit Ravine

4.7 Photograph showing outer margin of west depositional lobe on Pumice Plain

4.8 Components of mixed-avalanche deposit:

$A$. Plot of sample bulk density versus distance from avalanche source

(rock buttress on east crater wall)

$\boldsymbol{B}$. Rock fragments in mixed-avalanche deposit as a fraction of total solids (rock + ice) versus distance from avalanche source

4.9 Grain-size frequency histograms for mixed-avalanche, mixed-slushflow, and debris-flow deposits

4.10 Photograph showing nested nature of mixed-avalanche, mixed-slushflow, and water-flow deposits, visible from subtle tonal and textural changes, and watereroded channel, in crater breach at head of Loowit Ravine.

\section{CHAPTER 5}

FIGURE 5.1 Drainage network at Mount St. Helens

5.2 Photograph of oblique aerial view of Mount St. Helens crater showing lava dome and March 29, 1984, rock-avalanche fan

5.3 Seismograph record of March 29, 1984, from seismic station HOA

5.4 Photograph showing time-lapse photograph of incandescent rockfalls on March 31, 1984, resulting from spalling of newly extruded lava

5.5 Photograph of oblique southward aerial view of March 29, 1984, rock-avalanche fan .......... 75

5.6 Geologic map of rock avalanche-rockfall complex .......................................................... 76

5.7 Photograph showing undulating surface of snow at the base of unit A ............................... 77

5.8 Photograph showing exposure of unit B1 illustrating the poorly sorted, loose, dry texture of the deposit

5.9 Profiles of the north part of the Mount St. Helens dome on January 31, 1984, and April 14, 1984

\section{CHAPTER 6}

FigurE 6.1 Path of May 14, 1984, lahar and lahar runout and locations of selected measured cross sections.

6.2 Panorama from Johnston Ridge, about 7 kilometers north of the crater showing approximate extent of May 14 mixed snow and rock avalanche and slushflow and paths of various lobes of the lahar

6.3 Photograph of upstream view showing lahar recessional flow in the North Fork Toutle channel at about 1013 on May 14, 1984 ....

6.4 Photograph showing side view of a recessional-flow knickpoint 14 kilometers from vent at about 1014

6.5 Photograph of downstream view of North Fork Toutle River at 1016 ( 9 minutes after passage of lahar flow front) showing a series of oblique and normal wave fronts (hydraulic jumps?)

6.6 Photograph showing close up of bow-shaped wave front (hydraulic jump?)

6.7 Photograph showing upstream view of the North Fork Toutle River and sinuous, dunelike features (bed forms?) $16 \mathrm{~km}$ downstream from the vent immediately after passage of recessional surge shown in figures 6.5 and 6.6 


\section{ILLUSTRATIONS-Continued}

FIGURE 6.8 Sampling of the sediment-discharge peak at 1046, 24 kilometers downstream of the crater (at measured cross section NF335)

6.9 Longitudinal profile of the North Fork Toutle River from the crater to Elk Rock showing $A$, transition interval from slushflow to debris flow, and $B$, the transition interval from debris flow to hyperconcentrated flow

6.10 Sequential schematic stratigraphic sections showing upstream-downstream textural changes and depositional facies associated with the May 14, 1984 lahar

6.11 Photograph of aerial oblique view eastward at 1530 showing confluence of Steam Creek with North Fork Toutle River, about 9 kilometers downstream of the crater

6.12 Photograph showing diamict deposited as backfill in hanging tributary shown in fig. 6.11 (8 kilometers from the crater)

6.13 Photograph of downstream aerial oblique view of Steam Creek (about 6 kilometers from the lava dome) at 1336 showing ponding 3 hours after passage of the lahar flow front.

6.14 Photograph of terrace-capping deposits on the right bank of the North Fork Toutle River about 16 kilometers from the lava dome show evidence of the beginning of the transition from debris flow to hyperconcentrated flow

6.15 Cross section of dacite-breccia fragile clast rafted by the May 14, 1984 lahar, 16 kilometers from the lava dome

6.16 Sediment concentration (by weight) changes in a series of dip samples obtained on May 14, 1984, near the periphery of the lahar runout flow 24 kilometers from the Lava Dome (near cross section NF335).

6.17 Photograph showing downstream oblique view of knickpoint cut into debris-flow surface, 16 kilometers from the lava dome

6.18 Diagrammatic formation of bed forms in transition reach: $A$, Surging waves and scour during recessional flow on fresh lahar deposit; and $B$, knickpoint bed form and pumice-rich veneer remaining after tail of lahar drains away

6.19 Photograph showing depth of peak flow at (A) mudline 4 kilometers from the lava dome and (B) streamlined ridges and smoothed surface scoured by the May 14, 1984, debris flow

6.20 Selected cross-section plots of the North Fork Toutle River basin showing net erosion and deposition caused by the May 14, 1984, lahar....

6.21 Section of a seismogram from the Elk Rock Three seismograph (ERT), located about 24 kilometers downstream of the vent near the North Fork Toutle River

\section{APPENDIX 1.A}

FIGURE 1.A Definition of coordinate system for heat-flow analysis

1.B Inversion of lapace transform 


\section{CONTENTS}

\section{TABLES}

\section{CHAPTER 2}

TABLE 2.1 Erosion index values for monumented cross sections on the North Fork Toutle River

2.2 Characteristics of flood channels at Mount St. Helens and Mount Rainier where water floods have transformed to debris flows

\section{CHAPTER 3}

TABLE 3.1 Peak stream discharges at gaging stations along the course of the lahar of May 19, 1982 ......... 46

3.2 Average velocity of flood-wave front along the course of the lahar of March 19, 1982, in the Toutle River, Washington

3.3 Sediment discharges of lahar of March 19-20, 1982, in the Toutle River

3.4 Sediment discharge in sand-size classes at two-gaging stations along the course of lahar of March 19-20, 1982, in the Toutle River

3.5 Comparison of stream discharge and sediment transport on February 20 and March 20, 1982, at Toutle River at Highway 99

\section{CHAPTER 4}

TABLE 4.1 Properties and composition of mixed-avalanche deposit.....

4.2 Grain-size parameters of mixed-avalanche, mixed-slushflow, and debris-flow deposits.

\section{CHAPTER 6}

TABLE 6.1 Flow observations and erosional and depositional features for the May 14, 1984, lahar

6.2 Velocity, discharge, and associated channel data for the May 14, 1984, lahar 


\section{CONTENTS}

\section{CONVERSION FACTORS}

\begin{tabular}{|c|c|c|}
\hline Multiply & By & To obtain \\
\hline \multicolumn{3}{|c|}{ Length } \\
\hline millimeter $(\mathrm{mm})$ & 0.03937 & inch \\
\hline centimeter & 0.3937 & inch \\
\hline $\operatorname{meter}(\mathrm{m})$ & 3.281 & foot \\
\hline kilometer & 0.6214 & mile \\
\hline \multicolumn{3}{|c|}{ Area } \\
\hline square meter $\left(\mathrm{m}^{2}\right)$ & 10.76 & square foot \\
\hline & 1.196 & square yard \\
\hline \multirow{3}{*}{ square kilometer $\left(\mathrm{km}^{2}\right)$} & 0.0002471 & square acre \\
\hline & 0.3861 & square mile \\
\hline & \multicolumn{2}{|l|}{ Volume } \\
\hline liter $(\mathrm{L})$ & 0.2642 & gallon \\
\hline cubic centimeter & 0.06102 & cubic inch \\
\hline \multirow[t]{3}{*}{ cubic meter $\left(\mathrm{m}^{3}\right)$} & 35.31 & cubic foot \\
\hline & 1.308 & cubic yard \\
\hline & 0.0008107 & acre-foot \\
\hline cubic kilometer $\left(\mathrm{km}^{3}\right)$ & 0.2399 & cubic mile \\
\hline \multicolumn{3}{|c|}{ Volume per unit time (includes flow) } \\
\hline \multirow{4}{*}{$\begin{array}{l}\text { meter per second }(\mathrm{m} / \mathrm{s}) \\
\text { cubic meter per second }\left(\mathrm{m}^{3} / \mathrm{s}\right)\end{array}$} & 3.281 & foot per second \\
\hline & 35.31 & cubic foot per second \\
\hline & 15,850 & gallon per minute \\
\hline & Mass & \\
\hline kilogram $(\mathrm{kg})$ & 2.205 & pound avoirdupois \\
\hline \multirow[t]{2}{*}{ megagram $(\mathrm{Mg})$ or metric ton } & 1.102 & short ton $(2,000 \mathrm{lb})$ \\
\hline & Thermal energy & \\
\hline joule $(\mathrm{J})$ & $9.478 \times 10^{-4}$ & British thermal unit \\
\hline joule per kilogram $(\mathrm{J} / \mathrm{kg})$ & $4.298 \times 10^{-4}$ & British thermal unit per pound avoirdupois \\
\hline $\begin{array}{l}\text { joule per degree Kelvin } \\
\text { per kilogram }\left(\left[\mathrm{J} /{ }^{\circ} \mathrm{K}\right] / \mathrm{kg}\right)\end{array}$ & $2.388 \times 10^{-4}$ & $\begin{array}{l}\text { British thermal unit per degree Rankine } \\
\text { per pound avoirdupois }\end{array}$ \\
\hline & Temperature & \\
\hline degree Celsius $\left({ }^{\circ} \mathrm{C}\right)$ & ${ }^{\circ} \mathrm{F}=1.8\left({ }^{\circ} \mathrm{C}\right)+32$ & degree Fahrenheit \\
\hline
\end{tabular}




\title{
HYDROLOGIC CONSEQUENCES OF HOT-ROCK/SNOWPACK INTERACTIONS AT MOUNT ST. HELENS VOLCANO, WASHINGTON, 1982-84
}

\author{
By Thomas C. Pierson and Richard B. WaitT
}

\section{INTRODUCTION}

\section{CONTENTS}

Background

Types of hot-rock/snowpack interactions .

Processes of explosive eruptions....

Processes of lava-dome mass failures

Types and characteristics of sediment-water flows

Volcanic activity and research at Mount St. Helens

Acknowledgments

References cited

\section{BACKGROUND}

Emplacement or flowage of hot pyroclastic rock debris on or into thick snowpacks on volcanoes can trigger hazardous rapid flows of sediment (including ice grains) and water. Such rapid flows can extend far beyond the flanks of a volcano, as has been observed at volcanoes in many parts of the world (Major and Newhall, 1989). Commonly these sediment-water flows achieve discharges and velocities that produce catastrophic consequences more than $100 \mathrm{~km}$ downstream from source areas. The hazardous nature of such flows was most recently demonstrated in 1985 at Nevado del Ruíz volcano in Colombia, where snowmelt-generated sediment-water flows killed about 23,000 people (Lowe and others, 1986; Naranjo and others, 1986; Pierson and others, 1990).
Snow-covered stratovolcanoes like those in the Cascade Range and in Alaska commonly erupt explosively and produce potentially unstable lava domes. On such volcanoes volcanic explosions and mass failures from lavadomes are two primary mechanisms by which a hot rock having a large surface area is brought into contact with snow. Through this contact heat is effectively transferred to the snow, and large volumes of rapidly melted snow can trigger a variety of flows involving sediment (initially the hot volcanic debris) and water. Once triggered, the sediment-water flows are likely to erode and incorporate additional material from older deposits and thus increase in volume. In addition to providing the heat to melt snow, stratovolcanoes commonly provide other conditions favorable to the initiation of sediment-water flows: (1) high topographic relief and steep slopes; (2) the presence of poorly consolidated or unconsolidated, erodible pyroclastic rocks on slope surfaces; and (3) weakened structural integrity caused by hydrothermal alteration of rocks forming the edifice.

The details of interactions between hot pyroclastic rock fragments and snowpacks are poorly understood. Hydrologic consequences of eruptive activity are probably fairly common at snow-clad volcanoes but have largely gone unnoticed in the past owing to the remoteness of most such volcanoes, to the small-scale, short-lived nature of most of the phenomena, and to the sometimes enigmatic nature of deposits that once consisted partly of ice particles. 


\section{TYPES OF HOT-ROCK/SNOWPACK INTERACTIONS}

Dynamic mixing of hot pyroclastic material with snow seems to be a critical factor in effective heat transfer and the production of large sediment-water flows. Highly energetic processes that can occur from explosive eruptions and from mechanical failure of lava domes cause mixing through impact and penetration of snow by hot rock fragments and through turbulent shear at flow boundaries. Less energetic interactions between hot rock and snow, such as the laminar flow of lava over snow surfaces or the fall of hot tephra on snow with little or no penetration, produce relatively little meltwater (Major and Newhall, 1989). During the period 1982-84 hot-rock/snowpack interactions at Mount St. Helens were predominantly of the highly energetic type.

\section{PROCESSES OF EXPLOSIVE ERUPTIONS}

Explosive eruptions can add large quantities of heat and can apply destabilizing mechanical stresses to slopes adjacent to volcanic vents. Primary physical processes that can melt or destabilize snow and ice during these eruptions include: (1) explosive ejection of hot ballistic fragments, which can penetrate the snowpack to various depths, cause some physical mixing, and apply mass loading to slopes (fig. 1); (2) pyroclastic surges and pyroclastic flows, which thermally and mechanically erode and apply shear stresses to overridden snow surfaces (fig. 2); and (3) acoustic or seismic shock from volcanic explosions, which can momentarily cause a decrease in frictional resistance to failure in snow slopes. Even small explosive eruptions can be highly effective in fostering hot-rock/snowpack interactions because low-energy

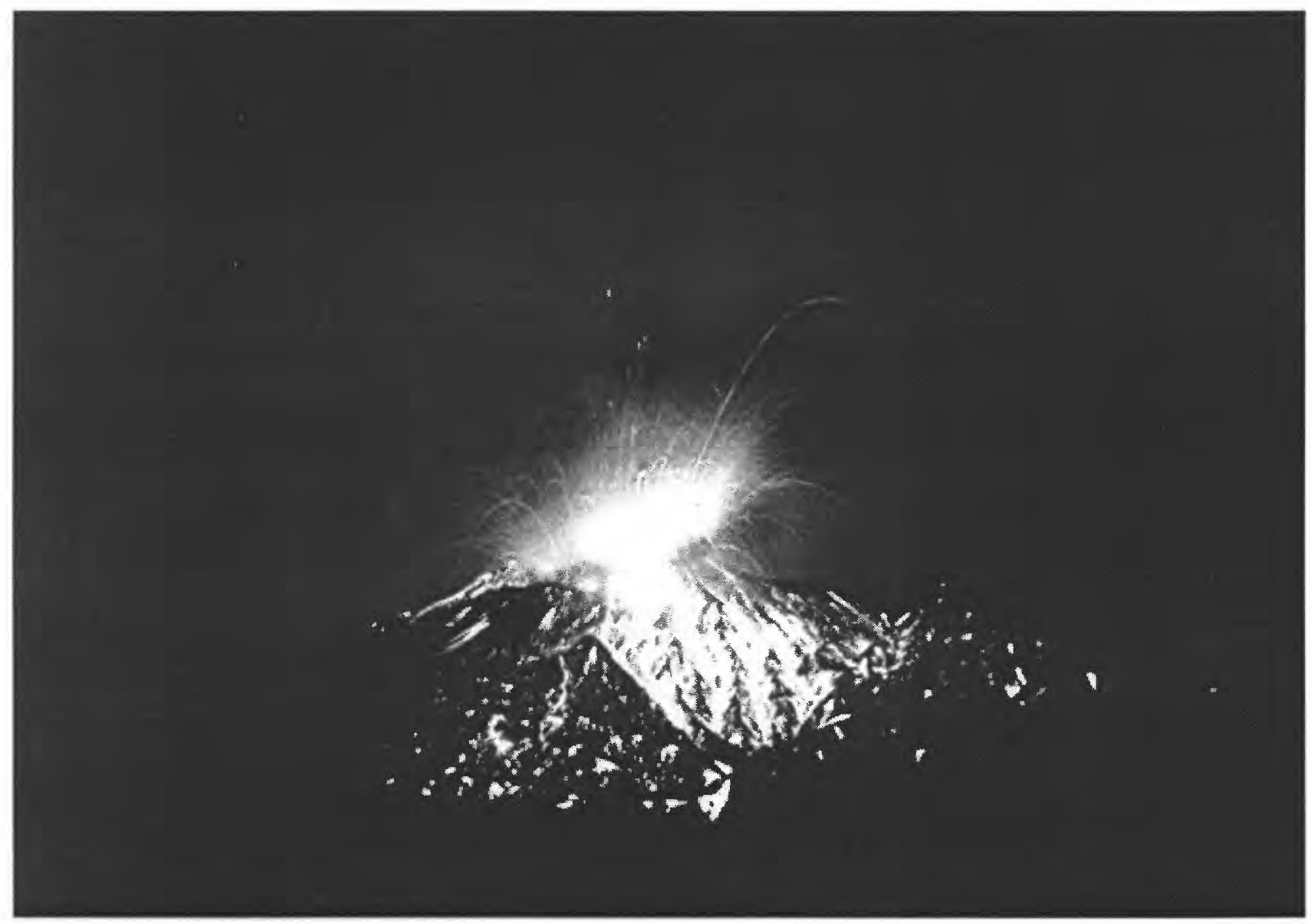

FIGURE 1.-Bombardment of slopes of Sakurajima volcano with incandescent rock fragments during nighttime eruption on February 11,1983 . This volcano is not snow-covered, but photograph shows density of ballistic surface impacts and the subsequent dry flow of hot particles (incandescent streams in valleys) during an explosive eruption. Photograph courtesy of Kosuke Kamo, Sakurajima Volcano Observatory, Japan. 
explosions may not disperse pyroclastics very widely, resulting in a focusing of hot debris on snow-covered slopes near the vent. Recent examples of explosive eruptions producing large sediment-water flows on snowcovered volcanoes include Mount St. Helens in 1980 (Pierson, 1985; Major, and Voight, 1986; Fairchild, 1987; Scott, 1988; Waitt, 1989) and Nevado del Ruíz in 1985 (Lowe and others, 1986; Naranjo and orhers, 1986; Pierson and others, 1990).

\section{PROCESSES OF LAVA-DOME MASS FAILURES}

Stratovolcanoes that erupt silicic magmas commonly produce lava domes. These bulbous masses of highly viscous lava grow as lava is erupted onto the surface or as it is injected into the interior. As a dome grows, the cooling exterior forms a brittle carapace that encloses a ductile, gas-pressurized lava core (Iverson, 1990). During periods of growth, or when a dome deforms under its own weight, gravitational stresses can cause mechanical failure of an unstable part of the dome (fig. 3). Such mass failures may be accompanied by minor explosions from the pressurized interior of the dome. The failed mass commonly moves out away from the dome as a hot, disintegrating rock avalanche, which usually transforms into a type of pyroclastic flow known as a block-and-ash flow. If the surrounding ground is snow covered, hot rock debris can effectively mix with the snow (fig. 4). Dome-collapse rock avalanches and explosions generated block-and-ash flows at Redoubt Volcano, Alaska, that triggered very large sediment-water flows in late 1989 and early 1990 (Major and others, 1990; Dorava and Meyer, 1994; Trabant and others, 1994; Waitt and others, 1994).

\section{TYPES AND CHARACTERISTICS OF SEDIMENT-WATER FLOWS}

Rapid release of meltwater on the flanks of a volcano will generally result in streams of water (or slurries of

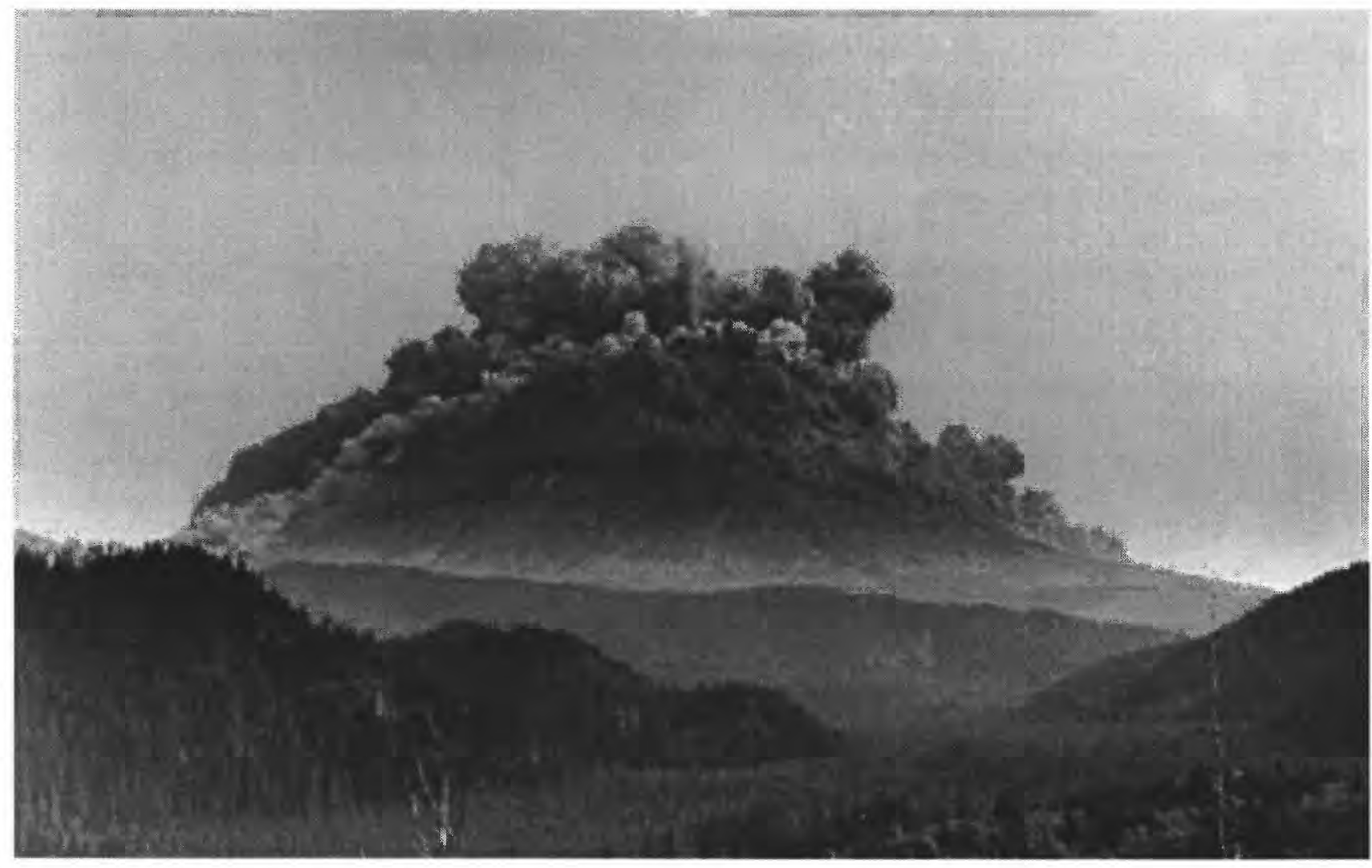

Figure 2.-Pyroclastic surges (dark turbulent clouds with steep flow fronts) descending snow- and ash-covered slopes of the south sector of Mount St. Helens at a velocity of about 50 meters per second during first moments of the May 18, 1980, explosive eruption (Pierson, 1985). Highly mobile sediment-water flows were generated. Photograph courtesy of Harold Fosterman. 
water and pyroclastic rock fragments) flowing downhill over easily erodible material_snow or loose, unconsolidated rock debris. Initial meltwater flows can readily scour and incorporate these types of material. Flow volume then increases due to this erosional bulking and can increase by up to an order of magnitude (Gallino and Pierson, 1985; Pierson and others, 1990). In the opposite sense, flows overtaking and mixing with streamflow in a river channel can become diluted (Pierson and Scott, 1985). Sediment-water mixtures containing ice also may be diluted as ice grains melt due to heat from incorporated volcanic debris or, to a lesser extent, from heat generated by friction during flow (Pierson and others, 1990).

A variety of types of sediment-water flow are possible, depending on the relative proportions of water and solid particles. Flow rheology depends on the grain-size distribution of the solid fraction as well as on the sediment: water ratio (Varnes, 1978; Pierson and Costa, 1987). Unsaturated (nonliquefied) granular mass flows of rock debris are classified as debris avalanches and are usually generated by gravitational collapse of some part of the volcanic edifice (Hsü, 1975; Voight, 1978; Ui, 1983; Siebert, 1984). Similar, predominantly granular flows of snow (with or without fragments of glacier ice) and admixed rock debris, classified as mixed avalanches, can occur as a consequence of explosive eruptions (Pierson and Janda, 1994; Waitt and others, 1994). Normal snow avalanches also can be triggered. Flows involving saturated (liquefied) slurries of rock debris and water are termed debris flows (Costa, 1984; Johnson, 1984). Such flows have significant shear strength and are capable of transporting large boulders. If large flows involve mostly water, they are generally simply described as floods, although flows that have sufficient entrained sediment to provide a small amount of shear strength and to dampen turbulence are termed byperconcentrated flows (Beverage and Culbertson, 1964; Pierson and Scott, 1985; Scott, 1988). Hyperconcentrated flows commonly occur as the more

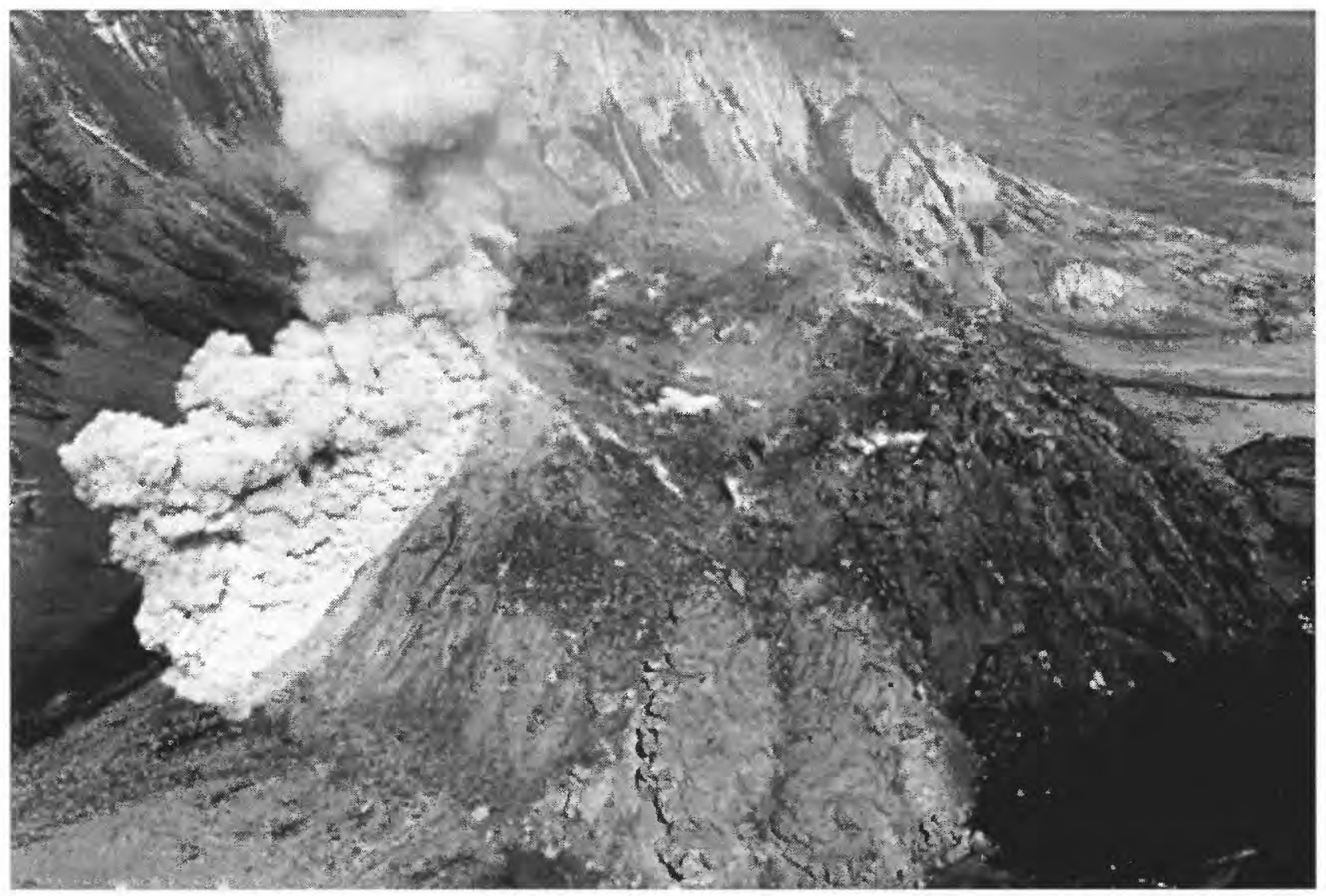

FigURE 3.-Small rockslide-avalanche (block and ash flow) in progress from Mount St. Helens lava dome, June 10, 1985. Avalanche comprises a hot, granular, basal flow and a hot, turbulent ash cloud. Lava dome is approximately 300 meters high. 
dilute downstream runout flows of some large debris flows. Flows involving undifferentiated debris flows, hyperconcentrated flows, or muddy floods, or all three at volcanoes are termed lahars (Smith and Lowe, 1991).

\section{VOLCANIC ACTIVITY AND RESEARCH AT MOUNT ST. HELENS}

Mount St. Helens (fig. 5) has been the most active Cascades volcano and a prolific producer of snowmeltgenerated sediment-water flows throughout post-glacial time (Scott, 1988). During the first minutes of the cataclysmic eruption on May 18,1980, devastating lahars

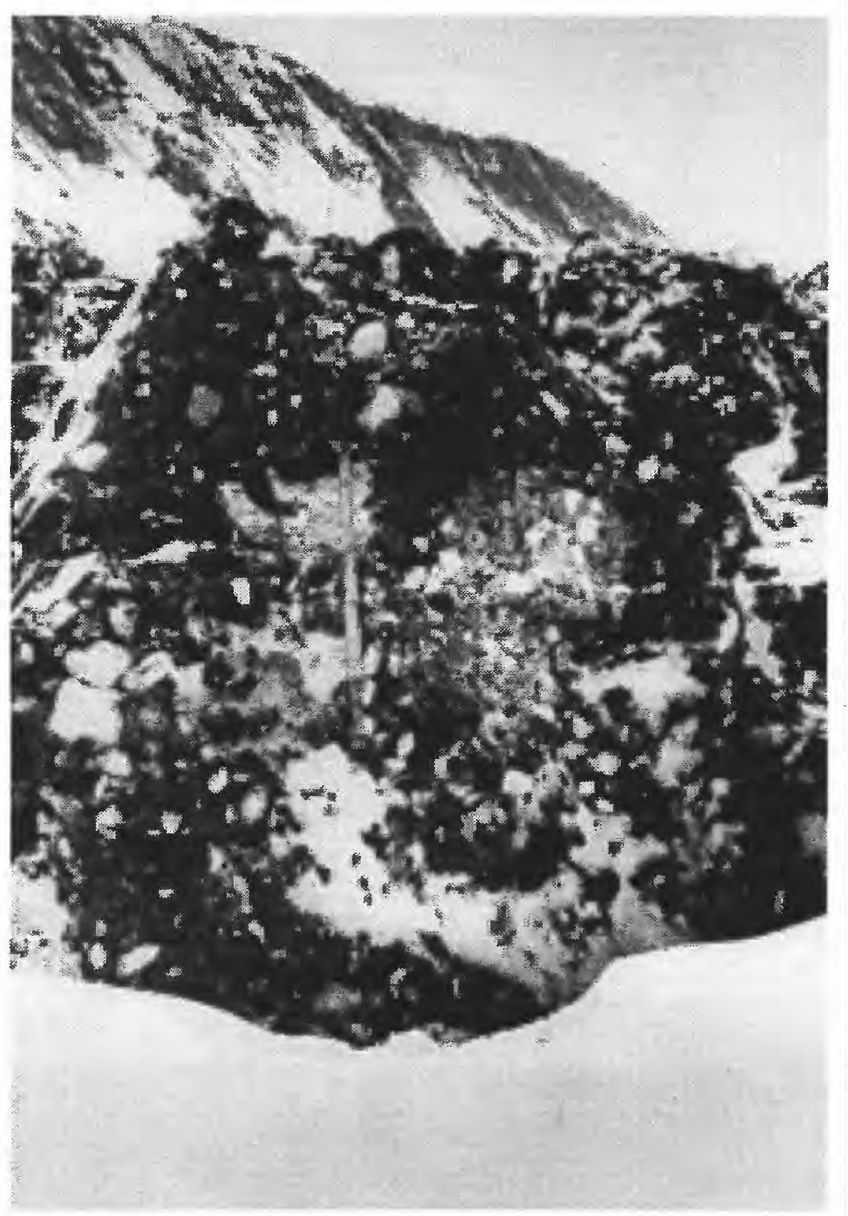

FIGURE 4.-Lobe of rock avalanche deposit showing thorough mixing of rock debris and snow. This cold rock avalanche originated from the west crater wall at Mount St. Helens on January 13, 1989, and flowed partway across the snowcovered crater floor. Ice-axe handle is approximately 80 centimeters long. Photograph courtesy of Kenneth Cameron. were generated suddenly on the east, south, and west flanks of the volcano. Field evidence indicated that the main cause was interaction of turbulent, high-velocity pyroclastic surges (and possibly underriding pyroclastic flows) with the snowpack. Yet some of the evidence is contradictory (Pierson, 1985; Major and Voight, 1986; Scott, 1988; Waitt, 1989), and the exact cause of the rapid snowmelt is not fully understood. Research on the 1980 flows was carried out only intermittently over months and years. Critical evidence, such as erosive features of snow surfaces or deposits containing snow or glacier ice, disappeared within weeks; therefore present understanding of the 1980 flows is unavoidably incomplete.

Between 1981 and 1986, the crater at Mount St. Helens (fig. 6) was an excellent place to examine hotrock/snowpack interactions and resultant sediment-water flows because (1) the shaded northern exposure of the crater allowed perennial snow to accumulate on the steep crater walls, talus slopes, and much of the crater floor, (2) those snow-covered surfaces were close to the dome, and (3) relatively frequent small explosive eruptions and minor dome collapses occurred. Eighteen small explosive eruptions, some accompanied by partial mass failures from the growing lava dome, were recorded during this period. A number of different interactions between hot rocks and snowpack were recorded by deposits and snowsurface morphologic features, and diverse types of sediment-water flows were triggered. Helicopter access allowed the field evidence of source areas and flow deposits to be quickly examined by U.S. Geological Survey teams, usually within a day of each event. Rapid response afforded unprecedented opportunities to examine the transient geologic records and to interpret the nature of these hot-rock/snowpack interactions.

The chapters of this volume examine the consequences of relatively small explosive eruptions and hot dome-collapse avalanches occurring in the presence of a snowpack at an active stratovolcano. Chapter 1 presents a theoretical and experimental analysis of the nature of depositional contacts between hot pyroclastic deposits and snow or ice. Chapters 2 through 6 present aspects of four volcanic events that occurred at Mount St. Helens and caused varying amounts of snowmelt in 1982,1983 , and 1984. One small eruption melted snow so rapidly and in such volume that a transient meltwater lake formed, then breached, sending sediment-water flows as far as $90 \mathrm{~km}$ downstream. Seismic monitoring, eyewitness accounts, and detection of eruptive plumes by civil-aviation radar supplemented geologic and 


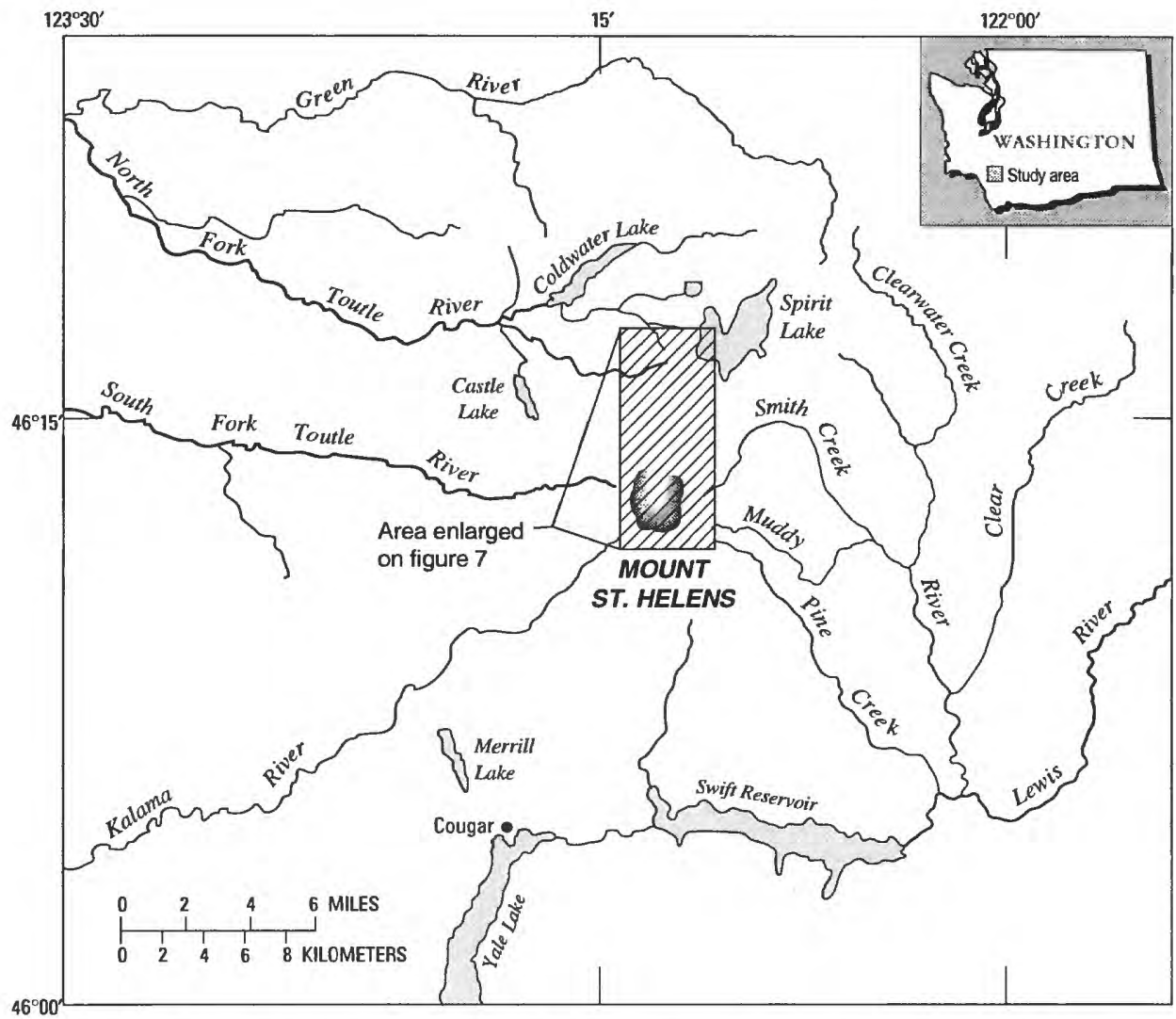

Figure 5.-Location map of the Mount St. Helens area showing major streams draining the volcano Inset rectangle shows area of map in figure 7.

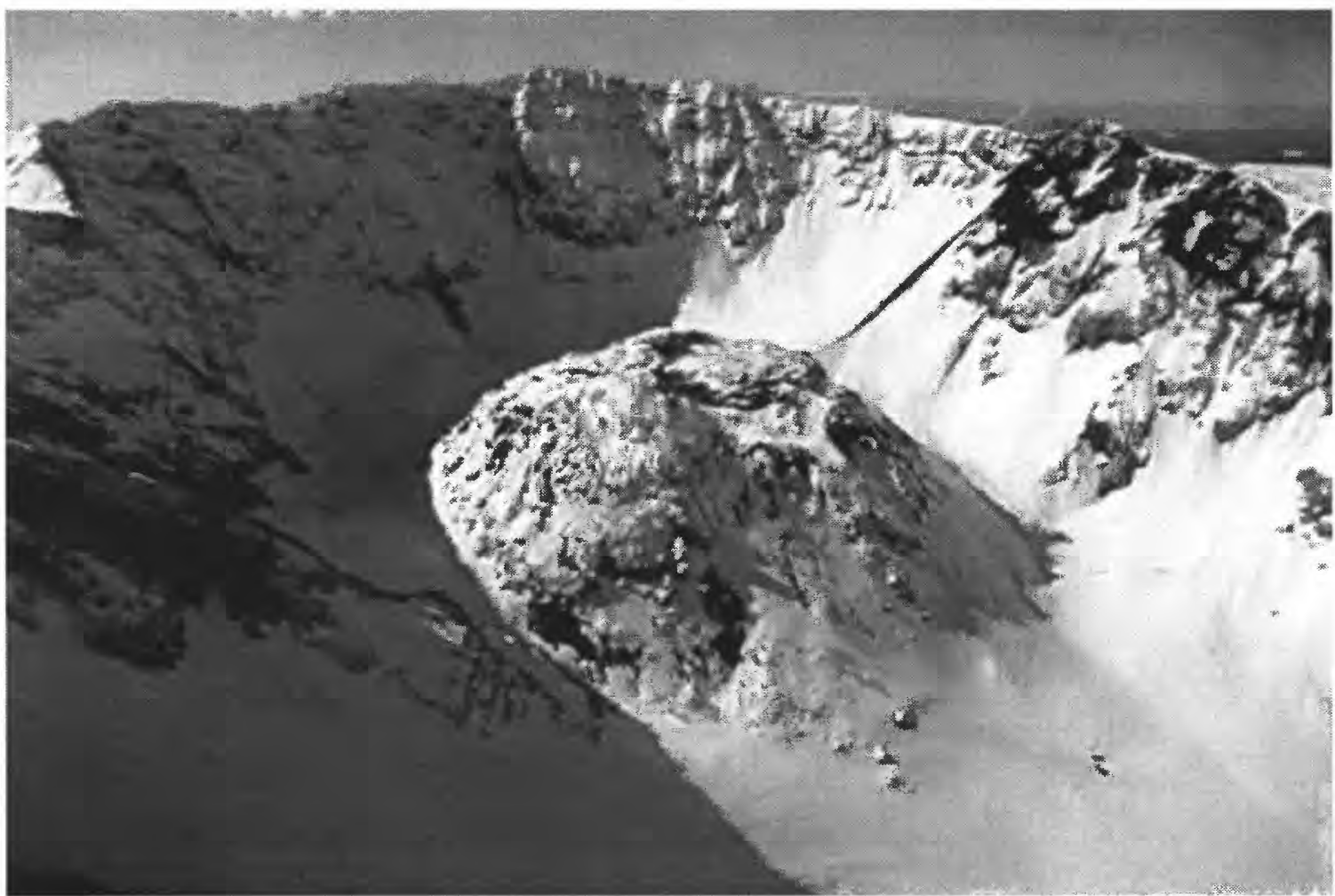

FiguRE 6.-Snow-covered lava dome and crater of Mount St. Helens on March 7, 1985. Lava dome is approximately 300 meters high. 
hydrologic field evidence. Although some of the events produced effects and generated sediment-water flows that seemed similar, no two events were the same.

Locations of key geographic features near the Mount St. Helens crater are depicted in figure 7. Chapters in this volume use the place names shown, which include both formal and informal names of features. The drainage features are continuing to evolve on this young landscape;

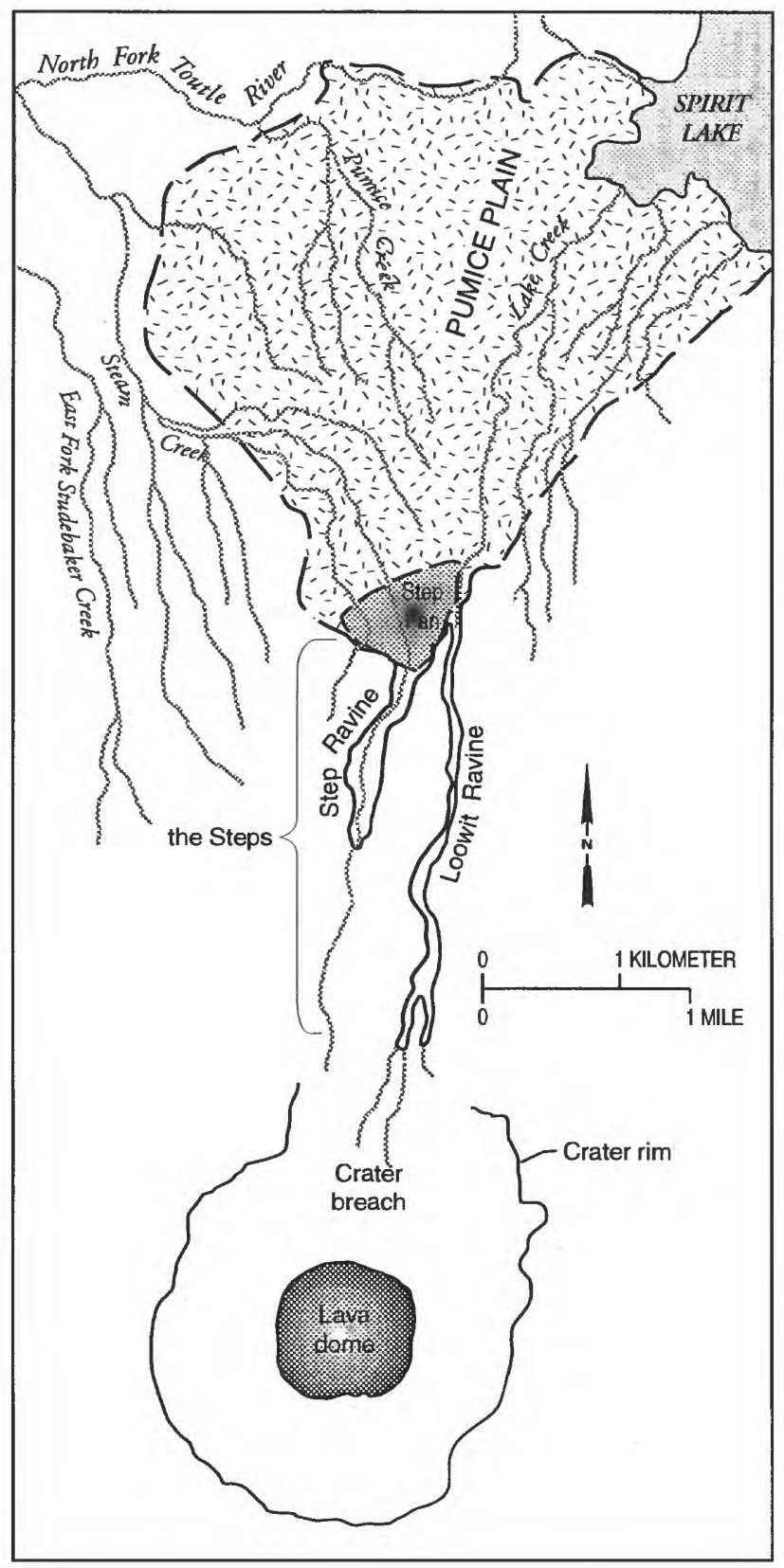

Figure 7.--Map of Mount St. Helens crater and Pumice Plain, which acts as head of the North Fork Toutle River. Geographic features and locations are indicated using both formal and informal geographic names. the features are drawn (fig. 7) approximately as they were in of 1984.

\section{ACKNOWLEDGMENTS}

Winter field investigations at an active volcano in mountainous terrain would not be possible without pilots, radio dispatchers, seismic observers, electronic technicians, and other colleagues in crucial support roles. Most areas affected by eruptions at Mount St. Helens in 1981-86 were accessible only by helicopter, and pilots made skillful landings under sometimes challenging conditions. Night-flight airplane pilots and observers, volcano-monitoring crews, and seismic interpreters provided information on the eruptions and provided a measure of safety for field crews in or near the crater. Some interpretations have been influenced by discussions over the years with colleagues both within and outside the U.S. Geological Survey. The editor and authors wish to thank all these unnamed individuals for their assistance.

\section{REFERENCES CITED}

Beverage, J.P., and Culbertson, J.K., 1964, Hyperconcentrations of suspended sediment: American Society of Civil Engineers Proceedings, Journal of the Hydraulics Division, v. 90, no. HY-6, pt. 1, p. 117-128.

Costa, J.E., 1984, Physical geomorphology of debris flows, in Costa, J.E., and Fleisher, P.J., eds., Developments and applications of geomorphology: Berlin, Springer-Verlag, p. 268-317.

Gallino, G.L., and Pierson, T.C., 1985, Polallie Creek debris flow and subsequent dam-break flood of 1980, East Fork Hood River basin, Oregon: U.S. Geological Survey WaterSupply Paper 2273, 22 p.

Dorava, J.M., and Meyer, D.F., 1994, Hydrologic hazards in the lower Drift River basin associated with the 1989-1990 eruptions of Redoubt Volcano, Alaska: Journal of Volcanology and Geothermal Research, v. 62, p. 387-407.

Fairchild, L.H., 1987, The importance of lahar initiation process, in Costa, J.E., and Wieczorek, G.F., eds., Debris flows/avalanches: Process, recognition, and mitigation: Geological Society of America, Reviews in Engineering Geology, v. 7, p. 51-62.

Hsü, K.J., 1975, Catastrophic debris streams (Sturzstroms) generated by rockfalls: Geological Society of America Bulletin, v. 86, no. 1, p. 129-140.

Iverson, R.M., 1990, Lava domes modeled as brittle shells that enclose pressurized magma, with application to Mount 
St. Helens, in Fink, Jonathan, ed., Lava flows and domes; emplacement mechanisms and hazard implication: Berlin, Springer-Verlag, p. 47-69.

Johnson, A.M., 1984, Debris flow, in Brunsden, Denys, and Prior, D.B., eds., Slope instability: Chichester, England, Wiley, p. 257-361.

Lowe, D.R., Williams, S.N., Leigh, Henry., Connor, C.B., Gemmell, J.B., and Stoiber, R.E., 1986, Lahars initiated by the 13 November 1985 eruption of Nevado del Ruíz, Colombia: Nature, v. 324, no. 6092, p. 51-53.

Major, J.J., and Newhall, C.G., 1989, Snow and ice perturbation during historical volcanic eruptions and the formation of lahars and floods: Bulletin of Volcanology, v. 52, no. 1, p. 1-27.

Major, J.J., and Voight, Barry, 1986, Sedimentology and clast orientations of the 18 May 1980 southwest-flank lahars, Mount St. Helens, Washington: Journal of Sedimentary Petrology, v. 56, no. 5, p. 691-705.

Major, J.J., Janda, R.J., Pierson, T.C., Waitt, R.B., LaHusen, R., Scott, W.E., Trabant, D., Brabets, T., and Miller, T.P., 1990, Debris flows and floods generated by eruption of Redoubt Volcano, Alaska-Consequences of interaction between snow and ice and volcanic debris [abs.]: Geological Society of America Abstracts with Programs, v. 22 , no. 7, p. 55 .

Naranjo, J.L., Sigurdsson, H., Carey, S.N., and Fritz, W.J., 1986, Eruption of Nevado del Ruíz Volcano, Colombia, on 13 November 1985-Tephra fall and lahars: Science, v. 233 , p. $961-963$.

Pierson, T.C., 1985, Initiation and flow behavior of the 1980 Pine Creek and Muddy River lahars, Mount St. Helens, Washington: Geological Society of America Bulletin, v. 96 , no. 8 , p. 1056-1069.

Pierson, T.C., and Costa, J.E., 1987, A rheologic classification of subaerial sediment-water flows, in Costa, J.E., and Wieczorek, G.F., eds., Debris flows/avalanches; process, recognition, and mitigation: Geological Society of America, Reviews in Engineering Geology, v. 7, p. 1-12.

Pierson, T.C., and Janda, R.J., 1994, Volcanic mixed avalanches: A distinct eruption-triggered mass-flow process at snow-clad volcanoes: Geological Society of America Bulletin, v. 106, p. 1351-1358.

Pierson, T.C., Janda, R.J., Thouret, J.C., and Borrero, C.A., 1990, Perturbation and melting of snow and ice by the 13 November 1985 eruption of Nevado del Ruíz, Colombia, and consequent mobilization, flow, and deposition of lahars: Journal of Volcanology and Geothermal Research, v. 41, p. 17-66.
Pierson, T.C., and Scott, K.M., 1985, Downstream dilution of a lahar-transition from debris flow to hyperconcentrated streamflow: Water Resources Research, v. 21, no. 10, p. 1511-1524.

Scott, K.M., 1988, Origins, behavior, and sedimentology of lahars and lahar-runout flows in the Toutle-Cowlitz River system [Mount St. Helens, Washington]: U.S. Geological Survey Professional Paper 1447-A, 74 p.

Siebert, Lee, 1984, Large volcanic debris avalanchescharacteristics of source areas, deposits, and associated eruptions: Journal of Volcanology and Geothermal Research, v. 22, no. 3/4, p. 163-197.

Smith, G.A., and Lowe, D.R., 1991, Lahars-volcanohydrologic events and deposition in the debris-flow/ hyperconcentrated-flow continuum, in Fisher, R.V., and Smith, G.A., eds., Sedimentation in volcanic settings: SEPM (Society for Sedimentary Geology) Special Publication 45, p. 59-70.

Trabant, D.C., Waitt, R.B., and Major, J.J., 1994, Disruption of Drift glacier and origin of floods during the 1989-1990 eruptions of Redoubt Volcano, Alaska: Journal of Volcanology and Geothermal Research, v. 62, p. 369-385.

Ui, Tadahide, 1983, Volcanic dry avalanche depositsidentification and comparison with nonvolcanic debris stream deposits: Journal of Volcanology and Geothermal Research, v. 18, no. 1/4, p. 135-150.

Varnes, D.J., 1978, Slope movement types and processes, in Schuster, R.L., and Krizek, R.J., eds., Landslides; analysis and control: Washington, D.C., National Research Council, Transportation Research Board Special Report 176, p. 11-33.

Voight, Barry (ed.), 1978, Rockslides and avalanches, 1.natural phenomena: Developments in geotechnical engineering 14a: Amsterdam, Elsevier, 833 p.

Waitt, R.B., 1989, Swift snowmelt and floods (lahars) caused by great pyroclastic surge at Mount St. Helens volcano, Washington, 18 May 1980: Bulletin of Volcanology, v. 52 , no. 2, p. 138-157.

Waitt, R.B., Gardner, C.A., Pierson, T.C., Major, J.J., and Neal, C.A., 1994, Unusual ice diamicts emplaced during December 15, 1989 eruption of Redoubt Volcano, Alaska: Journal of Volcanology and Geothermal Research, v. 62, p. 409-428. 


\title{
NATURE OF DEPOSITIONAL CONTACTS BETWEEN PYROCLASTIC DEPOSITS AND SNOW OR ICE
}

\author{
BY JOSEPH S. WALDER
}

\section{CONTENTS}

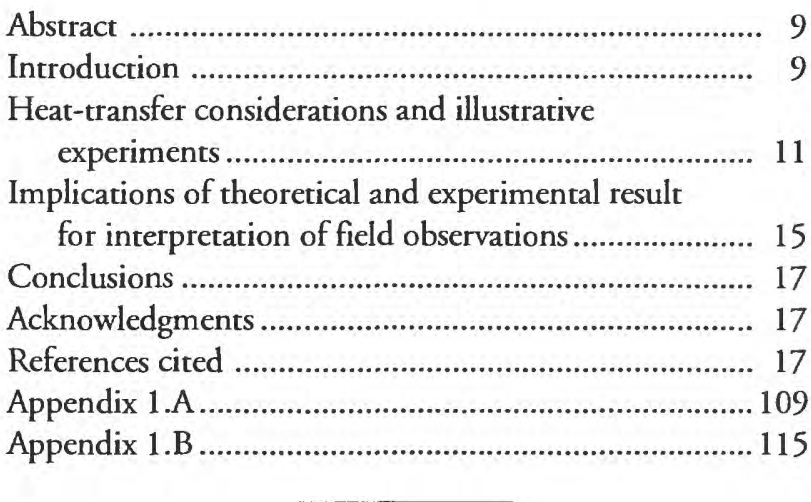

\begin{abstract}
Pyroclastic flows and surges moving over snow or ice commonly scour their substrates, as shown by deposits containing snow and glacier ice and by ravines cut into glacier surfaces. Yet observed contacts between pyroclastic deposits and snow or ice are in at least some places and at some scales sharply defined and smooth. Traditional stratigraphic principles provide equivocal guidance in interpreting such contact geometries: Do they reflect passive deposition without erosion, or uniform planing of the substrate by the flowing mass? I show that inferring process from form in this situation is problematic because of the unique circumstance of a substrate that can be melted by the overlying deposit. Analysis of heat transfer between a hot deposit and a frozen substrate indicates that for plausible values of initial deposit temperature, the depth of melting can easily be as much as the thickness of the deposit. Furthermore, the amplitude of irregularities on the
\end{abstract}

contact between pyroclastic debris and substrate is inevitably modified by spatial variability in melt rate: closely spaced irregularities (those with wavelength less than $2 \pi$ times the deposit thickness) tend to be destroyed, whereas more widely spaced ones tend to be amplified. Simple experiments illustrate the validity of the theoretical predictions, which are also consistent with observations made at Mount St. Helens and Redoubt Volcano. Accordingly, for the particular case at hand, an observed contact cannot be that which existed at the time of deposition, so one cannot make unequivocal inferences about amount or mechanics of interfacial scour on the basis of contact geometries.

\section{INTRODUCTION}

Pyroclastic flows moving over snow or ice commonly scour their substrates, as evidenced by deposits containing blocks of snow and ice, and by ravines cut into the surfaces of glaciers that mantle volcanoes (Mellors and others, 1988; Pierson and others, 1990; Thouret, 1990; Waitt and others, 1994; Major and Newhall, 1989). Yet contacts between pyroclastic deposits and snow or ice vary greatly: some contacts show substantial small-scale relief (fig. 1.1), whereas others are free of irregularities and are almost planar (fig. 1.2). One would hope to use such contact relations to learn about the mechanics of interaction between the pyroclastic flow and the frozen substrate, but application of traditional stratigraphic principles leads to somewhat of a quandary in this regard. One possible line of argument involves postulating process and predicting form, as follows: As a mass of rock clasts flows down a slope, some particles will collide with the slope; by analogy with the processes that form 


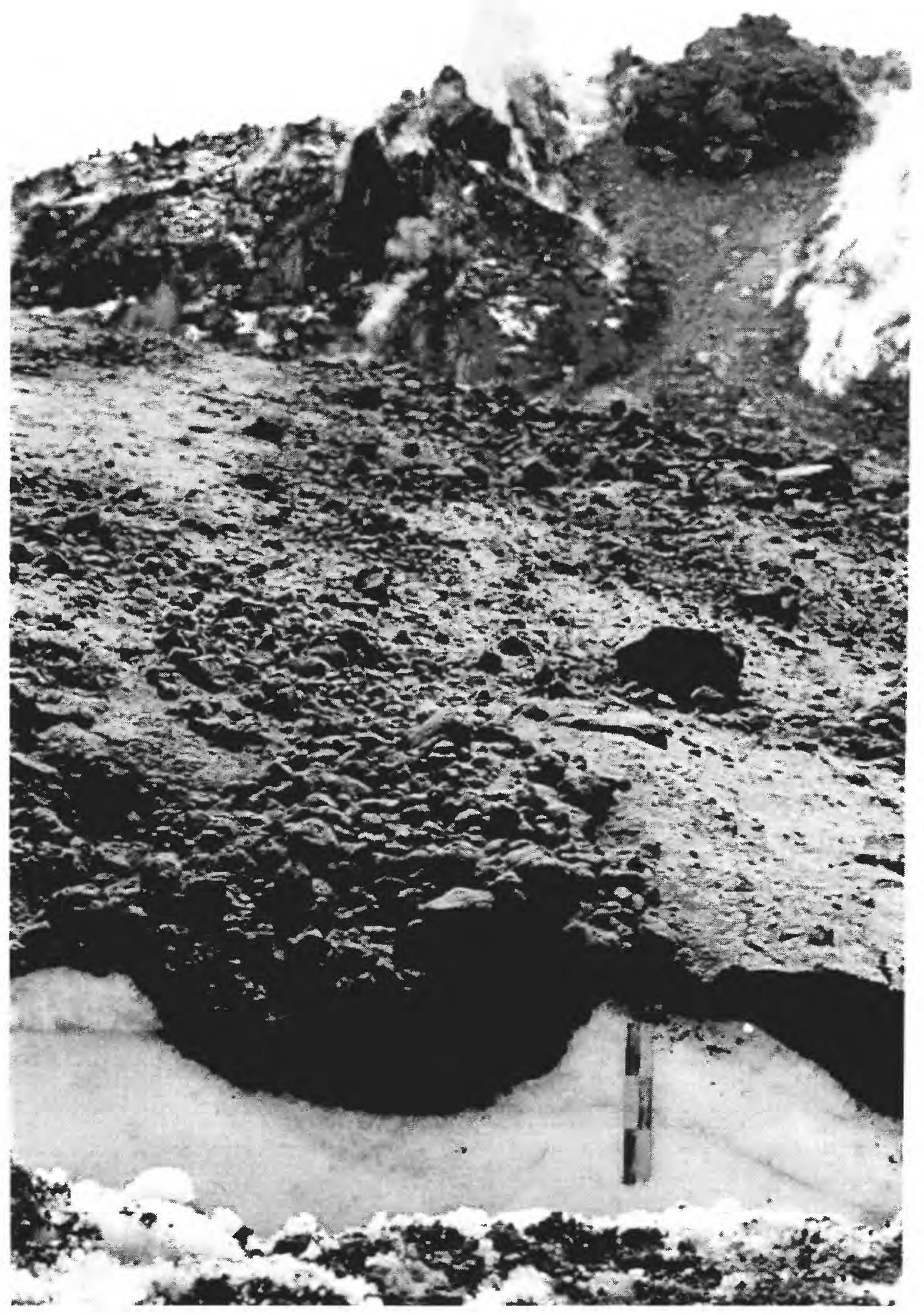

FiguRE 1.1.-Pyroclastic deposits lying on snow. Mount St. Helens, Washington. Cross section of linear ridge within pyroclastic deposit deposited on snow, May 9, 1986. The ruler is $15 \mathrm{~cm}$ long. Photograph by R.B. Waitt, U.S. Geological Survey. 
striations or sole marks in muddy sediment (Allen, 1985), one might reasonably expect the frozen substrate to be scoured as a result. A smooth contact between the pyroclastic deposit and the substrate then must reflect uniform erosion of the substrate. An alternative, but equally plausible, line of argument takes a different tack, beginning with form and inferring process: The presence of grooves in the snow/ice substrate reflects vigorous erosion of that substrate, whereas the absence of grooves means that the substrate was not scoured, and that the hot rock clasts flowed more or less passively over the snow or ice. Both lines of argument have been presented to me by colleagues and reviewers of this manuscript, with strong opinions as to the inadequacy of the "opposing" view; I therefore conclude that the issue is not a simple one!

I believe that the element missing from both of the above arguments is a clear recognition of the consequences of having a substrate that can be thermally eroded-or more simply, melted-by an overlying deposit even when that deposit is at rest. Postdepositional modification of the contact geometry is inevitable in this circumstance; the pertinent physics are summarized in the next section and elaborated in the analysis in Appendix 1.A. A perplexing, somewhat negative conclusion is that post-depositional modification of the contact is typically so great that neither of the aforementioned interpretations is likely to have much bearing on the effort to understand the mechanics of the interaction between hot flowing clasts and a frozen substrate. Carefully designed experiments are needed to reach that goal and are in progress.

\section{HEAT-TRANSFER CONSIDERATIONS AND ILLUSTRATIVE EXPERIMENTS}

Consider the situation depicted in figure 1.3 , which shows a hypothetical cross section through a pyroclastic deposit and its substrate (either snow or ice) at the instant

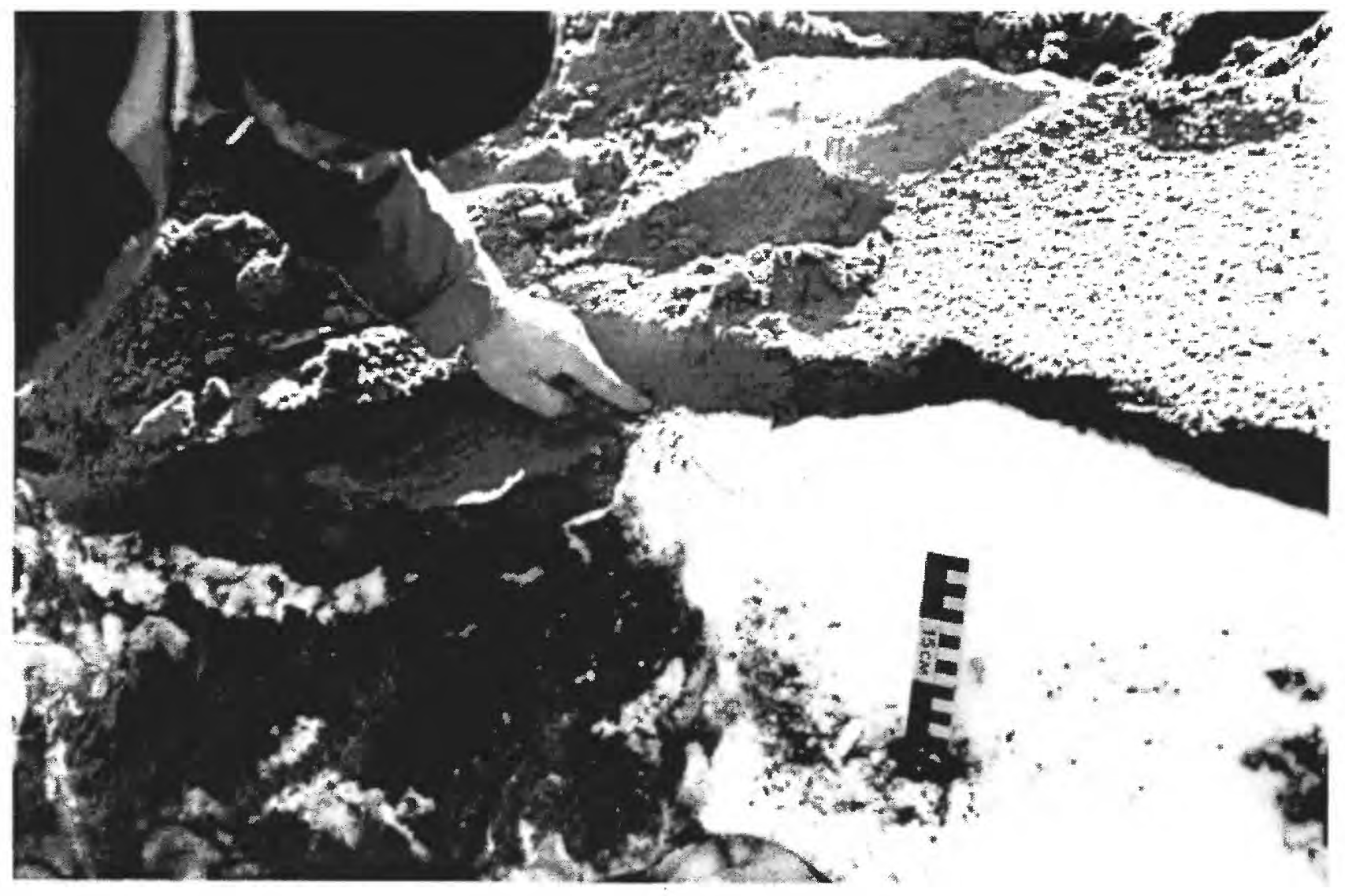

Figure 1.2.-Pyroclastic deposits lying on snow. Redoubt Volcano, Alaska. The exposure shown was excavated at a site visited within several hours of an eruption on March 23, 1990. Photograph by R.G. McGimsey, U.S. Geological Survey. 
at which the pyroclastic flow has come to rest. In the absence of direct knowledge of the mechanics of erosion, the least restrictive assumption one can make is that if the substrate is eroded by the pyroclastic flow, the eroded interface will be irregular, with some areas of the substrate scoured more deeply than others. My goal here is to assess whether, once flow ceases, topography at the interface (that is, the contact) will be modified by melting of the substrate, and if so, whether irregularities on the contact will tend to be enhanced or muted. I emphasize that the focus here is solely on post-depositional modification of the contact.

A hot pyroclastic deposit can melt a substantial quantity of snow or ice. An upper bound on the amount of melting caused by a pyroclastic layer of uniform thickness $L$ is easily found if one assumes that all thermal energy of the deposit goes into melting. Equating the specific heat change of the deposit to the latent heat required to melt, one finds

$$
\frac{l_{\mathrm{m}}}{L} \approx \frac{\rho_{\mathrm{p}} c_{\mathrm{p}} \Delta T}{(1-\varnothing) \rho_{\mathrm{i}} H}
$$

where $l_{\mathrm{m}}$ is the thickness of melted substrate, $\rho_{\mathrm{p}}$ is the density of the deposit, $c_{\mathrm{p}}$ is the specific heat of the deposit, $\emptyset$ is the substrate porosity (zero for pure ice), $\rho_{i}$ is the density of ice, $H$ is the heat of fusion, and $\Delta T=T_{\mathrm{d}}-T_{\mathrm{m}}$, with $T_{\mathrm{d}}$ the initial temperature of the deposit and $T_{\mathrm{m}}$ the melting temperature of snow or ice; measuring temperatures in degrees Celsius $\left({ }^{\circ} \mathrm{C}\right)$, one has $T_{\mathrm{m}}=0$ and thus $\Delta T=T_{\mathrm{d}}$. To estimate $l_{\mathrm{m}} / L$, take $\rho_{\mathrm{p}} / \rho_{\mathrm{i}}=1.5$ (corresponding to a moderately inflated deposit), $\emptyset=0.5$ (corresponding to dense, old snow),

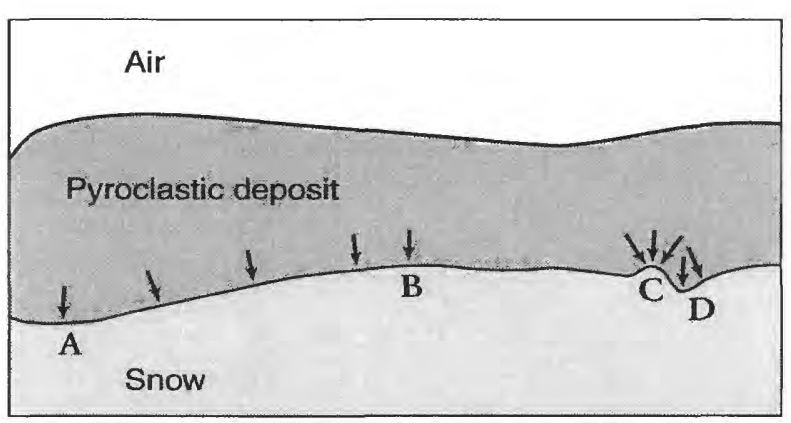

FIGURE 1.3.-Schematic cross section through a pyroclastic deposit of mean thickness $L$ overlying snow or ice. Heatflow vectors are shown schematically. A and B represent trough and peak, respectively, of a long-wavelength irregularity on the pyroclast/snow contact; $\mathrm{C}$ and $\mathrm{D}$ are peak and trough for a short-wavelength irregularity.
$H=3.35 \times 10^{5} \mathrm{~J} / \mathrm{kg}$, and $c_{\mathrm{p}} \approx 10^{3}\left(\mathrm{~J} /{ }^{\circ} \mathrm{K}\right) / \mathrm{kg}$, whence

$$
\frac{l_{\mathrm{m}}}{L} \approx 9 \times 10^{-3} T_{\mathrm{d}},
$$

where $T_{\mathrm{d}}$ is expressed in degrees Celsius; thus $l_{\mathrm{m}}=L$ for $T_{\mathrm{d}} \approx 110^{\circ} \mathrm{C}$. Pyroclastic deposits are commonly emplaced at temperatures of $600^{\circ} \mathrm{C}$ or greater (Banks and Hoblitt, 1981; Cas and Wright, 1987), and thus $l_{\mathrm{m}} / L \approx 6$ is a plausible upper bound. Even taking into account likely variations in $\rho_{\mathrm{p}} / \rho_{\mathrm{i}}$, along with the fact that sufficiently hot pyroclastic deposits might vaporize, rather than melt, underlying snow (Walder, 1992), it is clear that a substantial thickness of the substrate could be removed, with $l_{\mathrm{m}} / L-1$ a plausible orderof-magnitude estimate.

Simple experiments of the sort described below, in which a layer of hot sand was poured onto artificial snow (actually shaved ice), give amounts of melting consistent with the estimate above. This estimate is also consistent with observations related to the March 19, 1982, eruption of Mount St. Helens, Washington, USA (Waitt and others, 1983; Waitt and MacLeod, 1987; Pierson, chap. 2, this volume). During this eruption, pumice was deposited on the snow-covered crater floor and crater walls. Rapid melting resulted in the formation of a lake within the crater; the lake subsequently breached its dam and drained. Based on subsequent estimates of the lake volume and study of the pumice deposits, the thickness of snow melted was roughly equal to the thickness of the pumice deposit. Finally, note that melting may continue for a substantial period of time; observations at Nevado del Ruíz, Colombia, indicated runoff from snow and ice melted by pyroclastic deposits lasted for at least two days after deposition (Pierson and others, 1990).

I therefore conclude that, barring exceptional circumstances, any observed contact between pyroclastic deposits and either snow or ice cannot be the contact that existed instantaneously at the time of deposition. Yet with the exception of a brief comment by Mellors and others (1988), this retrospectively "obvious" result does not seem to have been explicitly recognized by field workers at snow- and ice-clad volcanoes. It is the first indication that traditional stratigraphic- and sedimentologic methods are at best suspect, and at worst inapplicable, in studying (formerly) hot deposits on snow or ice.

The argument presented above shows that the absolute position of the contact must change due to postdepositional melting, but says nothing about whether the shape of the contact will be changed. A simple 

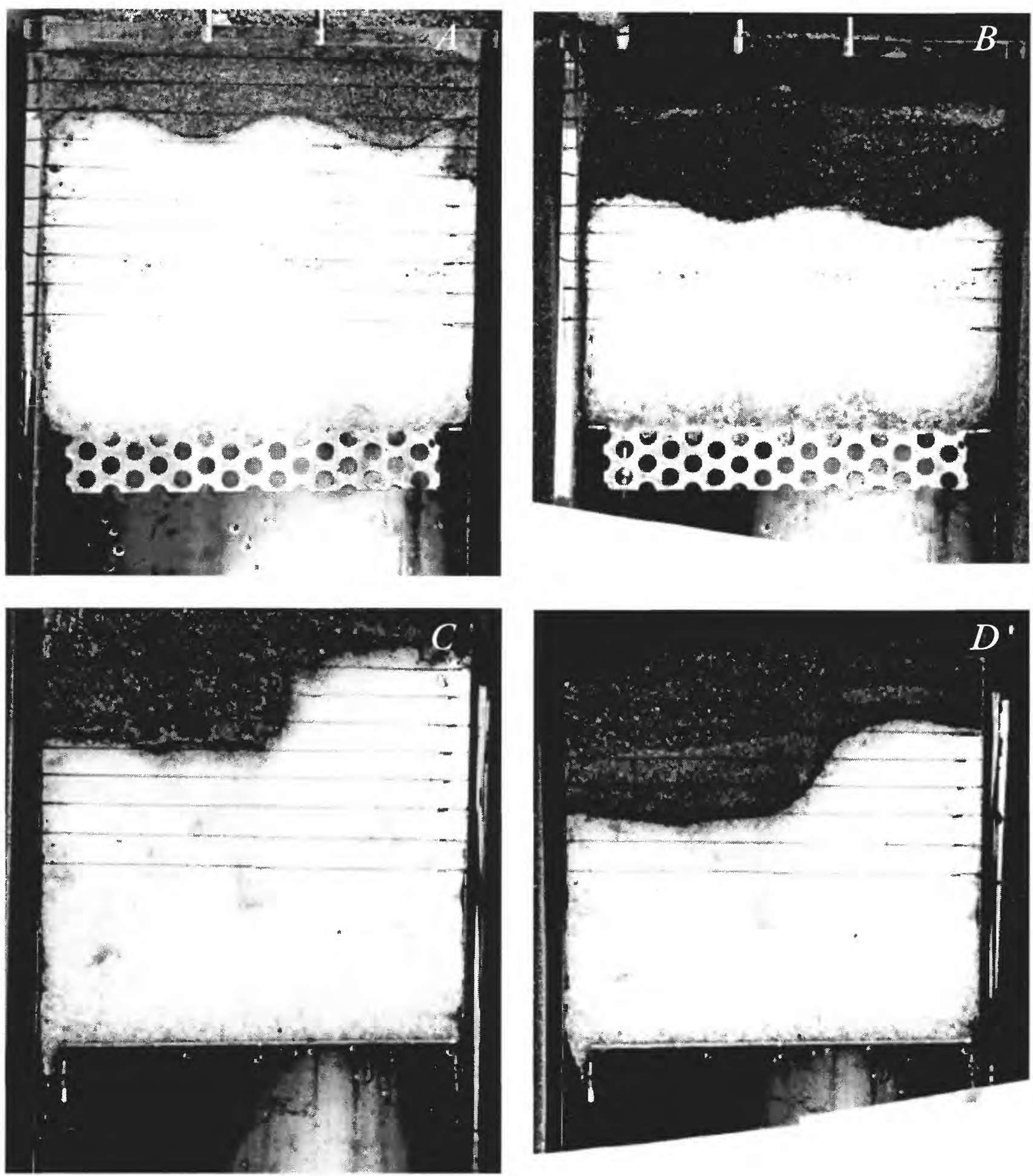

Figure 1.4.- Results of experiment to illustrate differential melting on an irregular interface. Hot sand $\left(150^{\circ} \mathrm{C}\right)$ was poured onto a bed of slightly packed, finely shaved ice. The plexiglas box containing the shaved ice was fitted with a false bottom to allow meltwater drainage. Horizontal lines on the box are at 10 -millimeter intervals. $A$, Initial state for a wavy irregularity. $B$, Modified wavy irregularity after 10 minutes contact with hot sand. Amplitude of the relief has been decreased by about one-third as peaks and troughs have migrated vertically downward. $C$, Initial state for a step-like irregularity. $D$, Modified step-like irregularity after 10 minutes contact with hot sand. Amplitude of the step has increased slightly, and the slope of the step has been reduced. 
experiment, described next, demonstrates that such change should in fact occur.

A plexiglas box was filled nearly to the top with "shaved ice" made with an Echols Microflake II ice shaver, a machine used commercially for making a confection commonly known in the United States as "Hawaiian ice." The ice shavings were quite fine, not gritty, and at above-freezing temperatures looked and tended to clump much like wet snow; to break up the largest clumps, the shaved ice was put through a $5.6-\mathrm{mm}$ sieve while filling the box, which was fitted with a false bottom to allow meltwater drainage. The shaved ice so prepared had a density of approximately $500 \mathrm{~kg} / \mathrm{m}^{3}$. The surface of the shaved ice was then shaped and slightly compacted, and the box was wrapped on three sides with foam insulation, the fourth side being left unobstructed to allow viewing. Hot, dark-colored sand was then poured onto the shaved ice up to the top of the box and photographs were taken to show temporal change of the contact between sand and shaved ice. In some experiments, a layer of foam insulation was placed on top of the sand, but this made no difference in the results, reinforcing the conclusion that heat loss to the melting substrate far exceeded loss to the atmosphere.

Figure 1.4 shows typical results of the experiments, which were of two sorts. For the case illustrated by Figs. $1.4 A$ and $1.4 B$, a piece of corrugated metal was pressed against the surface of the shaved ice to create a roughly sinusoidal form that had an amplitude of about $10 \mathrm{~mm}$ and a wavelength of about $75 \mathrm{~mm}$. The sand had an initial temperature of $150^{\circ} \mathrm{C}$ and a mean thickness of about $40 \mathrm{~mm}$. Melting caused the peaks and troughs of the contact to translate vertically downward. The amplitude of the relief on the contact was reduced by a factor of about one-third after about 10 minutes, by which time the sand had become noticeably wet.

For the experiment illustrated by Figs. $1.4 C$ and $1.4 D$, a nearly vertical step was cut into the shaved ice, the height of the step being 20 to $40 \mathrm{~mm}$ in the several runs with this geometry. The temperature of the sand was in the range $150^{\circ} \mathrm{C}$ to $200^{\circ} \mathrm{C}$, with a thickness of 20 to $40 \mathrm{~mm}$ over the upper step surface. In all runs with a vertical step, there was a slight increase with time in the step amplitude. The sand eventually became wet because of meltwater drawn up by capillary suction; little change in amplitude of the step occurred once capillary rise became noticeable. More noticeable than the change in the step amplitude was a change in its shape, which was invariably altered to a ramp.

The alterations in contact shape in these experiments can be explained by considering heat transfer between the hot sand and the shaved ice. (The same line of reasoning will apply for pyroclastic deposits resting on snow.) One may reasonably expect that whether or not contact irregularities are enhanced by melting depends on their spacing $\lambda$. In line with standard results in heatconduction theory (Carslaw and Jaeger, 1959), the time scale for the deposit to lose all of its heat is about $L^{2} / \kappa$, whereas the time scale for local heat redistribution (fig. 1.3) is about $\lambda^{2} / \kappa$, where $\kappa$ is the deposit's thermal diffusivity; accordingly, one may expect peaks on the contact to capture heat from troughs if $\lambda / L$ is less than about one, whereas for more widely spaced irregularities, the depth of melting should depend simply on the local deposit thickness (eq. 1.1). This qualitative expectation is supported by results of the analysis in Appendix 1.A, where I show that for small-amplitude irregularities that is, for the case in which initial irregularities at the contact are much less than the mean thickness of the pyroclastic deposit-irregularities with wavelength $\lambda<2 \pi L$ will tend to be destroyed, whereas those with $\lambda>2 \pi L$ will tend to be enhanced. For the experiment illustrated in figures $1.4 A$ and $1.4 B, \lambda \approx L$, and therefore one would expect the irregularities to be damped, as indeed was observed. For the experiment shown in figures $1.4 C$ and $1.4 D$, even though the amplitude of the step is obviously not small compared to the mean thickness of the sand, the small-amplitude theory is still qualitatively applicable. To see this, note that the shape of an ideal vertical step may be represented by a Fourier series:

$$
A(x)=\frac{2 h}{\pi} \sum_{m=0}^{\infty}\left(\frac{1}{2 m+1}\right) \sin \frac{(2 m+1) \pi x}{W}
$$

where $b$ is the height of the step, $W$ is the width of the box, and $A(x)$ is the (mathematical) amplitude of the contact at a horizontal position $x$ (fig. 1.5). Equation 1.3 has the property that $A(x)=-h / 2$ for $-W / 2<x<0$, $A(x)=h / 2$ for $0<x<W / 2$, and $A(x)=0$ for $x=0$. Thus the shape represented by equation 1.3 contains components of wavelength $\lambda_{m}=2 \mathrm{WI}(2 m+1)$, $m=0,1,2,3 \ldots$. For large enough $m, \lambda_{m} / L<2 \pi$, so those short-wavelength components will be damped. Conversely, the longest wavelength components $\left(\lambda_{m} / L<2 \pi\right)$ will tend to be enhanced. Because the shortwavelength components are what give the step its corners, the step should tend to become ramp-like, as observed.

The foregoing discussion leads to the conclusion that 
in general the shape, as well as the absolute position, of any contact between a pyroclastic deposit and an underlying substrate of either snow or ice will be substantially altered by melting; in particular, melting may exaggerate some irregularities on the contact while at the same time damping or destroying others. Almost certainly, then, the observed contact relation no longer contains information pertaining to scour of the substrate, and any attempt to make inferences about extent or mechanics of scour based on the contact relation is likely to be illusory. This frustrating conclusion seems unavoidable.

\section{IMPLICATIONS OF THEORETICAL AND EXPERIMENTAL RESULTS FOR INTERPRETATION OF FIELD OBSERVATIONS}

Field observations illustrate some of the phenomena discussed in the preceding section, as well as some potential pitfalls of traditional stratigraphic interpretation. A useful initial example is provided by the observations of Mellors and others (1988) at Mount St. Helens of effects of a hot-rock avalanche from the dome that formed within the crater left by the 1980 eruption. The avalanche occurred on May 9, 1986, while substantial spring snowpack remained. Mellors and others (1988, p. 18-19) observed linear ridges within pyroclastic-flow deposits and noticed that some of these

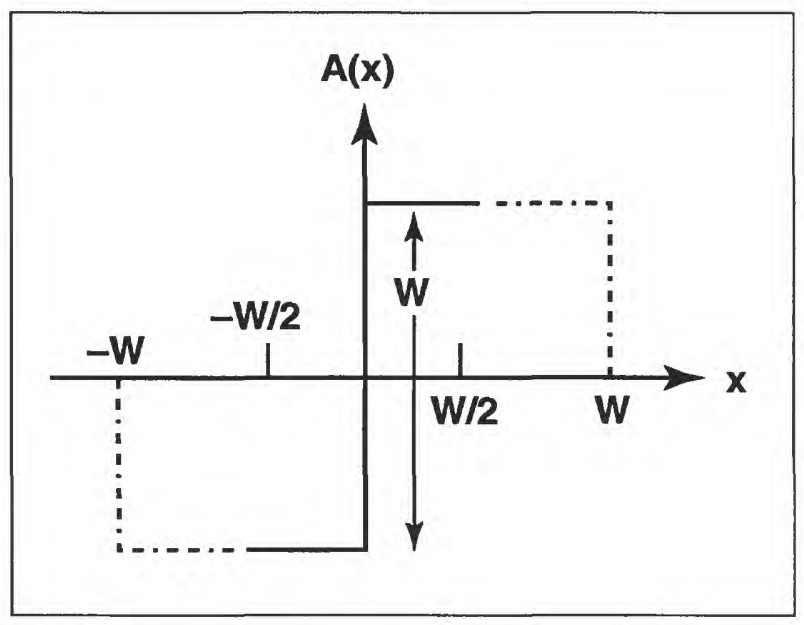

FiguRE 1.5.-Definition of coordinate system for Fourier-series description of step in contact between snow and overlying pyroclasts. ridges "coincided with furrows in the snow," as shown in figure 1.1. They went on to suggest that "differential erosion and melting of underlying snow may have contributed to this topography."

The observed contact relation in figure 1.1 could in principle have resulted simply from differential erosion. On the basis of the heat-transfer considerations discussed in the preceding section, however, one would also expect differential melting after deposition; an initial furrow beneath a ridge of hot material should tend to become both deeper and broader-that is, a V-shaped furrow should tend to become U-shaped - because of the same sort of spatial variability of heat conduction that altered a step to a ramp in the experiments illustrated by figures 1.4C and 1.4D. Thus in the example drawn from Mellors and others (1988), differential erosion-or indeed any amount of erosion-cannot be unequivocally inferred simply on the basis of the contact geometry.

Observations from Redoubt Volcano in Alaska also illustrate the sort of interpretational ambiguities associated with hot deposits that melt their substrate. The eruption of December 14-15, 1989, produced unusual diamicts containing clasts of rock and glacier ice (Pierson and Janda, 1994; Waitt and others, 1994). When first observed (within a few days of the eruption), these deposits already were solidly frozen; the matrix largely comprised ice, apparently from eroded snow and refrozen meltwater. This deposit blanketed most of the piedmont lobe of Drift Glacier [informal name of Sturm and others (1988)], which drains northward from the summit crater, as well as parts of glaciers on other flanks of the volcano. Pierson and Janda (1994) and Waitt and others (1994) estimated that only about 10 to 20 percent of the deposit consisted of rock; accordingly, its presence on moderately steep slopes (more than $10^{\circ}$ ) strongly suggests that its liquid-water content at the time of deposition must have been small — otherwise the material would have easily flowed (cf. Nobles, 1966). It is hard to avoid the conclusion that the diamict was on average relatively cold, probably only slightly warmer than the freezing point, when it ceased to flow. [Local hot spots due to large rock clasts may have existed, however, and caused melting that reworked the surface of the diamict (Waitt and others, 1994).] Therefore, little melting of the substrate would be expected, consistent with my observations at Drift Glacier in July 1990, when subsequent volcanic activity had cut numerous deep ravines into the ice. Exposures along such ravines (fig. 1.6) showed the still-frozen diamict partly filling some crevasses, but bridging others; a plausible 
interpretation is that the deposits had filled the snowfree upper parts of crevasses without melting the subjacent snow. Local relief at the contact between diamict and glacier ice was as much as a few meters, consistent with the scale of local irregularities that probably existed on the undisturbed glacier. Thus, the contact between the diamict and the underlying glacier ice probably underwent little, if any, post-depositional thermal modification. The same conclusion was reached by Waitt and others (1994).

The icy diamict deposits at Redoubt Volcano were subsequently blanketed by snow, which was in turn overridden and scoured by pyroclastic flows and surges that left deposits on top of the diamict. Contacts between pyroclastic deposits and diamict were relatively smooth compared to those between the diamict and glacier ice, an observation that lead Waitt and others (1994) to conclude that the "mechanically resistant" diamict" had undergone little if any erosion by the moving pyroclasts. By way of comparison, glacier ice, which is probably about as "mechanically resistant" as the icy diamict, is known to develop furrow-like erosional scours during passage of hot flows that leave no deposits (Pierson and others, 1994; Waitt and others, 1994).

The interpretation of Waitt and others (1994) is plausible, but there are alternatives. The diamict might have been continuously protected from flowing pyroclasts by a layer of snow that subsequently melted, thereby lowering the pyroclastic deposit onto the diamict. Yet another possibility is that the moving pyroclasts scoured completely through the blanket of snow and then moved directly over the diamict; in this case, melting of the diamict during passage of the pyroclasts, as well as after depostion thereof, might have occurred. Such melting would smooth out much of any erosional roughness that might have been created. It is difficult to see how the nature of the pyroclast-diamict contact permits an unambiguous reconstruction of physical processes at the pyroclast-diamict boundary.

Finally, I mention my observations near the western edge of the Drift Glacier's piedmont lobe, where pyroclastic deposits rested on snow. Such contacts showed very little small-scale relief and were much like

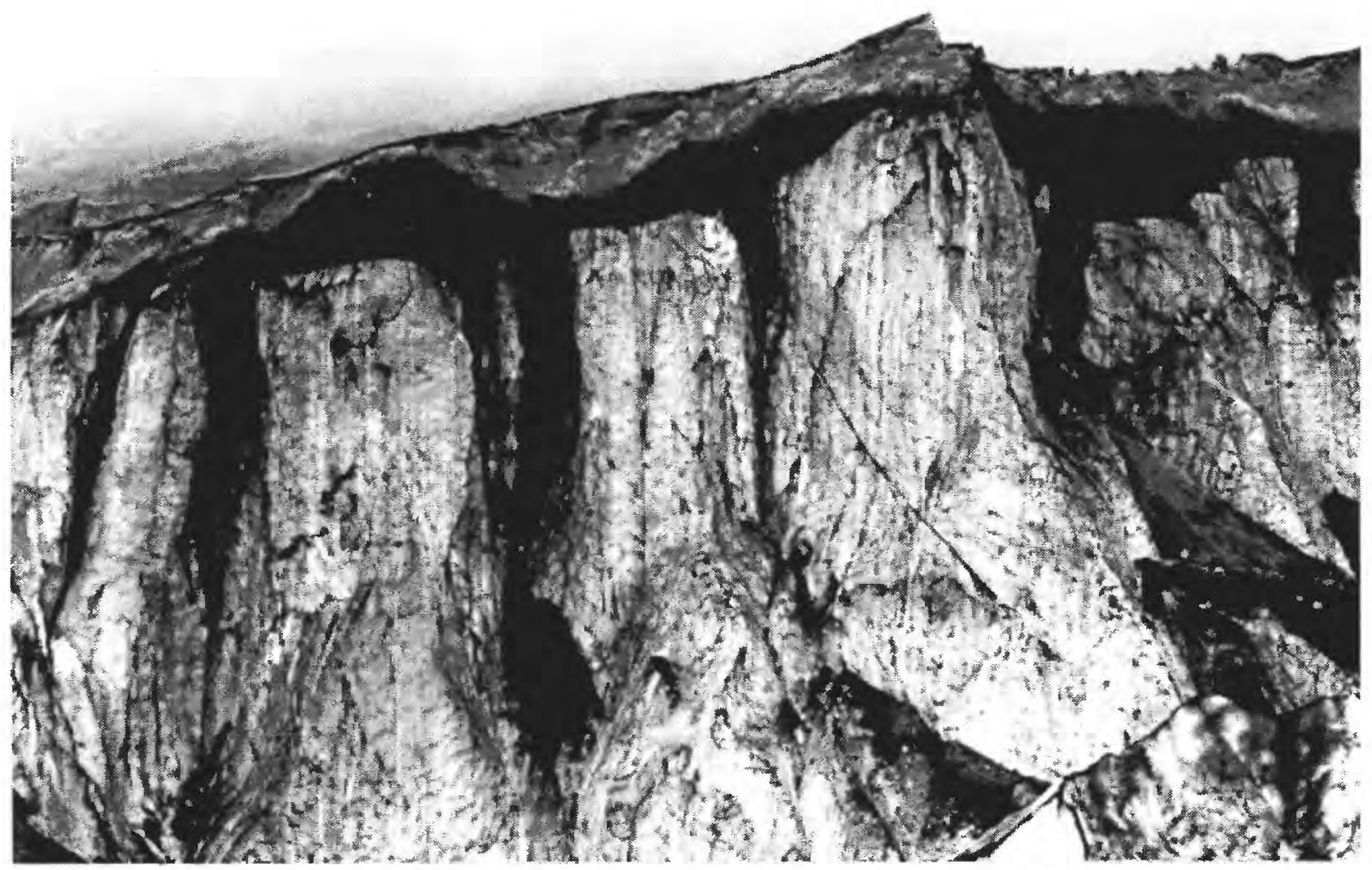

Figure 1.6.-Ice-cemented mixed-avalanche deposits on Drift Glacier, Redoubt Volcano, Alaska. The exposure is along a deep ravine carved into the glacier by repeated eruptions. Glaciological constraints (Paterson, 1994) suggest the exposed crevasses are probably about 20 meters deep. 
that shown in Fig. 1.2. (I did not find exposures that would permit assessment of the relief over horizontal distances of many meters.) Snow immediately beneath the deposits, over a thickness of about $0.5 \mathrm{~m}$, was typically rather hard, appeared to contain a lot of refrozen meltwater, and sometimes had a dirty cast. This hard snow was in places underlain by discontinuous ice lenses several centimeters thick, and these were in turn underlain by soft, clean snow. Because the thick blanket of pyroclastic deposits effectively insulates the snow from solar radiation and heat transfer from the atmosphere (Driedger, 1981), another heat source must be invoked to explain the apparent melting. I suggest that the pyroclastic deposits melted underlying snow to a depth of about $0.5 \mathrm{~m}$ subsequent to deposition (assuming a snow density of about $500 \mathrm{~kg} / \mathrm{m}^{3}$ ), and that the melt water percolated downward before refreezing. Such a large amount of melting would have destroyed any contact features that could have provided information about mechanical interaction of the pyroclastic flow and the snow substrate. Alternatively, the refrozen meltwater within the snowpack might have been derived from melting of snow that fell on top of the pyroclastic deposits.

\section{CONCLUSIONS}

Eruptions of snow- and ice-clad volcanoes often cause substantial disruption of that snow and ice. To try to understand the mechanical interaction between a hot clastic flow and a snow- or ice substrate, inspecting the subsequent deposits and the contact geometry would seem to be standard, useful field methods. Unfortunately, traditional modes of stratigraphic and sedimentologic interpretation are questionable for the particular, and perhaps peculiar, case of pyroclastic deposits laid down on snow or ice. Post-depositional melting will tend to destroy precisely the sort of features, such as grooves or other indicators of scour, that might yield useful information. There seems to be no way around this phenomenon in the field.

Laboratory studies, albeit at much smaller scale than actual volcanic events, do hold promise for understanding the physics of interaction between hot clastic flows and snow or ice. Deposits can be literally frozen in place immediately after emplacement (for example, with a blast of liquid nitrogen) and subsequently dissected. Such laboratory sedimentologic studies, along with appropriate measurements made while hot flows are in motion, are in progress (Walder, 1992, 1995).

\section{ACKNOWLEDGMENTS}

I wish especially to thank Cynthia Gardner, Paul Delaney, and Roger Denlinger for their incisive reviews of earlier versions of this paper. Discussions with Jon Major and Chris Paola while at Redoubt Volcano, and with Richard Iverson, Richard Waitt and Edward Wolfe at the Cascades Volcano Observatory, helped clarify my thinking. Waitt and Wolfe each provided a photograph used in this chapter.

\section{REFERENCES CITED}

Allen, J.R.L., 1985, Principles of physical sedimentology: London, George Allen and Unwin, $272 \mathrm{p}$.

Banks, N.G., and Hoblitt, R.P., 1981, Summary of temperature studies of 1980 deposits, in Lipman, P.W., and Mullineaux, D.R., eds., The 1980 eruptions of Mount St. Helens, Washington: U.S. Geological Survey Professional Paper 1250, p. 295-313.

Baer, M.R., and Nunziato, J.W., 1986, A two-phase mixture theory for the deflagration-to-detonation transition (DDT) in reactive granular materials: International Journal of Multiphase Flow, v. 12, no. 6, p. 861-889.

Carrier, G.F., and Pearson, C.E., 1976, Partial differential equations-theory and technique: New York, Academic Press, $320 \mathrm{p}$.

Carslaw, H.S., and Jaeger, J.C., 1959, Conduction of heat in solids (2d ed.): Oxford, Clarendon Press, 510 p.

Cas, R.A.F., and Wright, J.V., 1987, Volcanic successions, modern and ancient-A geological approach to processes, products and successions: London, Allen and Unwin, $528 \mathrm{p}$.

Driedger, C.L., 1981, Effect of ash thickness on snow ablation, in Lipman, P.W., and Mullineaux, D.R., eds., The 1980 eruptions of Mount St. Helens, Washington: U.S. Geological Survey Professional Paper 1250, p. 757-760.

Levinson, Norman, and Redheffer, R.M., 1970, Complex variables: San Francisco, Holden-Day, 429 p.

Major, J.J., and Newhall, C.G., 1989, Snow and ice perturbation during historical volcanic eruptions and the formation of lahars and floods: a global review: Bulletin of Volcanology, v. 52, p. 1-27.

Mellors, R.A., Waitt, R.B., and Swanson, D.A., 1988, Generation of pyroclastic flows and surges by hot-rock avalanches from the dome of Mount St. Helens volcano, USA: Bulletin of Volcanology, v. 50, no. 1, p. 14-25.

Nobles, L.H., 1966, Slush avalanches in northern Greenland and the classification of rapid mass movements, in International symposium on scientific aspects of snow and ice avalanches, Davos, Switzerland, 1965: International Association of Scientific Hydrology Publication 69, p. 267-272.

Paterson, W.S.B., 1994, The physics of glaciers (3rd ed.): Oxford, Pergamon Press, 480 p. 
Pierson, T.C., and Janda R.J., 1994; Volcanic mixed avalanches: A distinct eruption-triggered mass-flow process at snowclad volcanoes: Geological Society of America Bulletin, v. 106 , no. 10 , p. $1351-1358$.

Pierson, T.C., Janda, R.J., Thouret, J.C., and Borrero, C.A., 1990, Perturbation and melting of snow and ice by the 13 November 1985 eruption of Nevado del Ruíz, Colombia, and consequent mobilization, flow, and deposition of lahars: Journal of Volcanology and Geothermal Research, v. 41, p. 17-66.

Ryan, M.P., Banks, N.G., Hoblitt, R.P., and Blevins, J.Y.K., 1990, The in-situ thermal transport properties and the thermal structure of Mount St. Helens eruptive units, in Ryan, M.P. ed., Magma transport and storage: New York, John Wiley and Sons, p. 137-155.

Sturm, Matthew, Benson, C.S., and MacKeith, Peter, 1988, Recent glacier-volcano interactions on Mt. Redoubt, Alaska: Alaska Department of Natural Resources, Division of Geological and Geophysical Surveys, Report of Investigations, v. 88-9, $18 \mathrm{p}$.

Thouret, J.-C., 1990, Effects of the November 13, 1985 eruption on the snow pack and ice cap of Nevado del Ruíz volcano, Colombia, in Williams, S.N., ed., Nevado del
Ruíz Volcano, I: Journal of Volcanology and Geothermal Research, v. 41, no. 1-4, p. 177-201.

Waitt, R.B., Jr., Pierson, T.C., MacLeod, N.S., Janda, R.J., Voight, Barry, and Holcomb, R.T., 1983, Eruptiontriggered avalanche, flood and lahar at Mount St. Helenseffects of winter snowpack: Science, v. 221, no. 4618, p. 1394-1397.

Waitt, R.B., Gardner, C.A., Pierson, T.C., Major, J.J., and Neal, C.A., 1994, Unusual ice diamicts emplaced during the December 15, 1989 eruption of Redoubt Volcano, Alaska: Journal of Volcanology and Geothermal Research, v. 62 , nos. $1-4$, p. $409-428$.

Walder, J.S., 1992, Movement of pyroclastic flows over "snow": An experimental and theoretical study [abs.]: Eos (Transactions, American Geophysical Union), v. 73, no. 43 (supplement), p. 612.

Walder, J.S., 1995, Role of fluidization in pyroclast/snow interactions and lahar generation [abs.]: Eos (Transactions, American Geophysical Union), v. 76, no. 46 (supplement), p. F199.

Whitaker, Stephen, 1977, Fundamental principles of heat transfer: Malabar, Florida, R.E. Krieger Publishing Co., $556 \mathrm{p}$. 


\title{
2:
}

\section{TRANSFORMATION OF WATER FLOOD TO DEBRIS FLOW FOLLOWING THE ERUPTION- TRIGGERED TRANSIENT-LAKE BREAKOUT FROM THE CRATER ON MARCH 19, 1982}

\author{
By Thomas C. Pierson
}

\section{CONTENTS}

Abstract

Introduction

Lake-breakout flood

Transient-lake formation

Transient-lake breakout

Discharge estimation

Flow transformation of the flood

Channel environment for flow transformation

Sedimentologic evidence for transformation to

debris flow

Continued erosion and bulking by debris flow

Factors for transformation to debris flow

Factors for the March 19, 1982 flood

Factors for other flow events

Mount St. Helens crater-Loowit Ravine, smaller discharge

North Fork Toutle River valley-Breakout of small landslide-dammed lake

Mt. Rainier-Glacier-outburst floods................ 33

Summary and conclusions .......................................... 33

Acknowledgments ................................................... 35

References cited 35

\section{ABSTRACT \\ A critical but poorly understood aspect of flash floods in mountainous terrain is their potential to incorporate large}

volumes of eroded sediment and to transform to debris flows, thereby increasing in flood volume, peak discharge, flow velocity, erosional capacity, and hazard to life and property. A well-documented example of such a flow transformation occurred at Mount St. Helens on March 19, 1982, when an explosive eruption rapidly melted snow and ice, producing a transient lake that grew to a volume of 3 to $4 \times 10^{6}$ cubic meters before rapidly draining. The consequent flood, which was released in two major flood waves, transformed from water flow to debris flow as it progressed down the steep, deeply incised north flank of the volcano. Peak flood discharge approximately quadrupled and flow volume tripled in this transformation, which was accomplished over a distance of less than three kilometers.

Critical factors for the transformation of a water flood to debris flow in this type of setting seem to be high discharge (relative to channel capacity) and channel-bank height, slope, and erodibility. In this and several other examples, transformations have occurred after the initial water floods passed bank-to-bank through narrow channel reaches bounded by high ( $>20$ meters), oversteepened $\left(>45^{\circ}\right)$ banks consisting of noncohesive sands and gravels_-reaches where large-scale bank failures could introduce substantial volumes of unconsolidated sediment directly into the flow.

\section{INTRODUCTION}

Flash floods or sudden releases of large volumes of water, such as from dam failures, are in themselves 
significantly hazardous hydrologic events. Under certain circumstances, however, water floods have eroded and incorporated sufficient sediment to transform to debris flows (O’Shea, 1954; Richardson, 1968; Jackson, 1979; Yesenov and Degovets, 1979; Blown and Church, 1985; Clague and others, 1985; Laenen and others, 1987; Driedger and Fountain, 1989). A flow transformation ${ }^{1}$ from water to a dense, viscous slurry of water and rock debris can increase flood volume, peak discharge, flow velocity, and erosion capacity (bed shear stress) all by at least a factor of 5 (Pierson, 1980; Costa, 1984; Gallino and Pierson, 1985; Pierson and others, 1990). Whether such transformations occur is of particular interest to those modeling dam-break floods in mountainous terrain (for example, Swift and Kresch, 1983; Laenen and Orzol, 1987; Laenen and others, 1987). At present (1994), the factors responsible for transformation to debris flow are not understood and debris-flow transformations cannot be predicted.

A laterally directed blast from the south side of the Mount St. Helens lava dome heralded the onset of the March 19, 1982, eruption, during which hot volcaniclastic debris dynamically interacted on a massive scale with crater snow (Waitt and others, 1983; Waitt and MacLeod, 1987). A meltwater transient lake formed within tens of minutes and then drained rapidly, producing a lahar-a rapidly flowing mixture of water and sediment from a volcano (Smith and Lowe, 1991). The lahar initially had the characteristics of a water flood; it subsequently eroded and incorporated enough sediment to transform to a debris flow, which continued flowing downstream for 25 kilometers before transforming to hyperconcentrated flow (Waitt and others, 1983; Pierson and Scott, 1985). The debris-flow phase of the lahar continued to erode and incorporate sediment along most of this flowpath.

The fresh deposits left by the events of March 19 provided an opportunity to document the conditions under which a transformation from water flow to debris flow occurred. This chapter documents in more detail than in previous accounts the formation of the transient lake that produced the flood, and it examines the factors

\footnotetext{
1 "Flow transformation" is used here to connote fundamental changes in rheology and flow behavior caused by an increase in sediment concentration. In contrast to this use, Fisher (1983) has limited the term to describe changes in the flow state (laminar or turbulent flow) and flow continuity (homogeneous or segregated flow).
}

constraining flood discharge. Channel characteristics then are described for the reaches in which transformation occurred and in which the debris flow continued to evolve. The purpose of the study was to determine which factors seemed most directly related to the transformation of a water flood to a debris flow.

\section{LAKE-BREAKOUT FLOOD}

\section{TRANSIENT-LAKE FORMATION}

The initial explosion of the March 19, 1982, eruption was directed against the steep south crater wall, where it dislodged most of the snow over a $120^{\circ}$ sector on that 500-m-high slope (Waitt and MacLeod, 1987). Snow and hot blast debris avalanched down off the crater wall, coalescing to form a $10^{6}$ to $10^{7} \mathrm{~m}^{3}$ mixed avalanche of snow and hot debris (see Pierson and Janda, 1994) that traveled around the dome and north out of the crater, reaching as far as $9 \mathrm{~km}$ from its source (Waitt and others, 1983) (fig. 2.1). More explosions followed within the next 2 to 3 minutes, during which time dacite pumice began erupting. Hot pumice landed directly on the south crater floor and on the crater walls, from where it slid onto the crater floor. Heat from the pumice rapidly melted snowpack and snow-avalanche deposits on the crater floor, and large quantities of meltwater also flowed directly off the crater walls (Waitt and MacLeod, 1987).

Meltwater ponded over a thick snowpack in the moat formed at the south end of the crater between the lava dome and the crater walls, and it was filled with rapidly accumulating meltwater and juvenile deposits from the eruption. The water eventually formed a lake about $0.3 \mathrm{~km}^{2}$ in area that varied from 8 to $15 \mathrm{~m}$ in depth and contained 3 to $4 \times 10^{6} \mathrm{~m}^{3}$ of water and floating pumice (fig. 2.2). The transient lake was partly impounded by the lava dome and by talus cones impinging from the east and west crater walls, but no obvious evidence of damming by other deposits was preserved at the outlets following lake drainage (Waitt and others, 1983).

Altitudes of the highest pumice-block strandline around the transient-lake shore generally ranged between about $1,938 \mathrm{~m}$ and $1,942 \mathrm{~m}$; maximum lake level was approximately $1,942 \mathrm{~m}$. Locally, pumice deposited directly by dome explosions or by landslides down the crater walls was present above the highest strandline. The area of the transient lake was covered by 4 to $8 \mathrm{~m}$ of juvenile pumice blocks, lapilli, ash, and sparse lithic fragments (Waitt and others, 1983). Collapse structures 


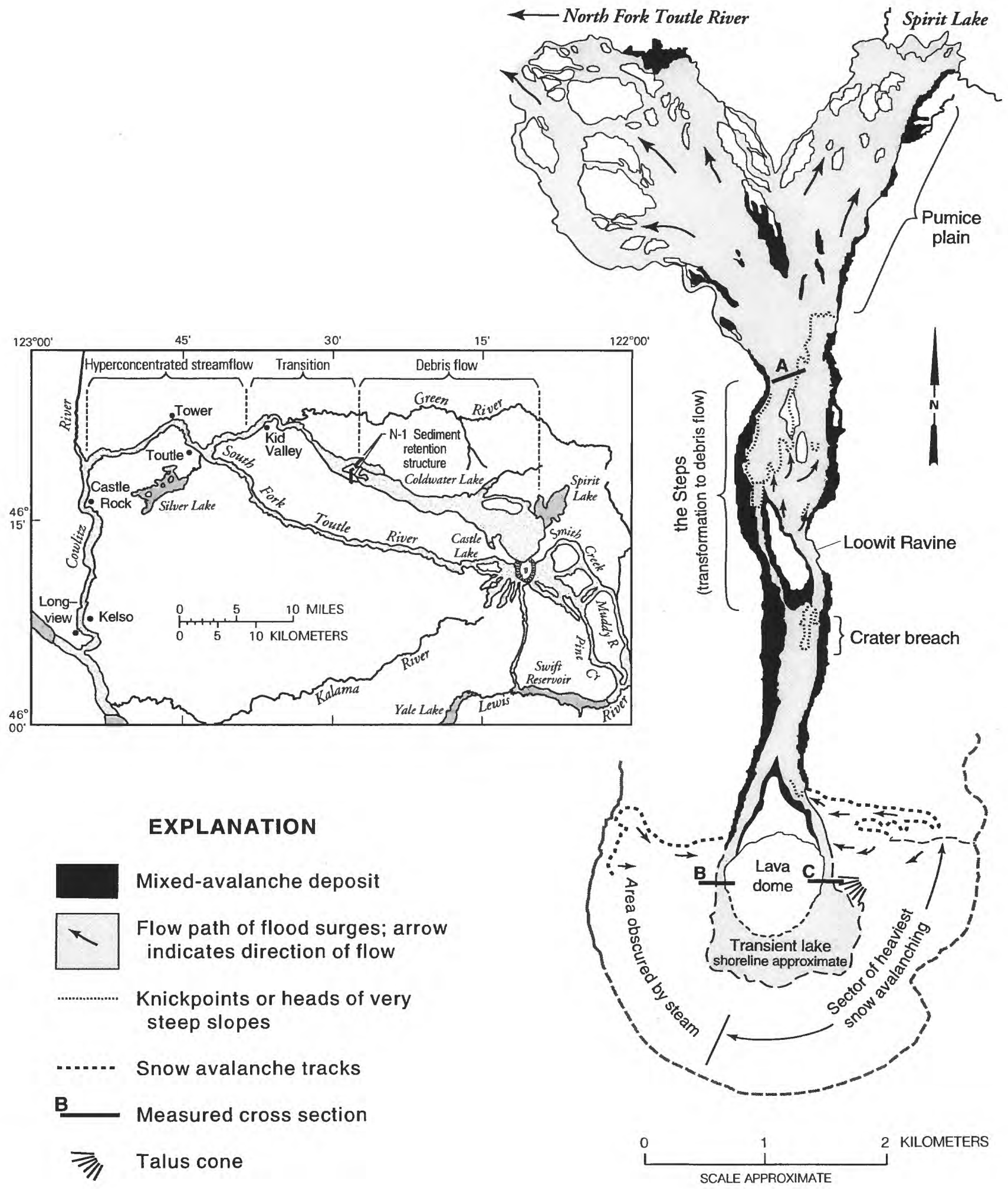

Figure 2.1.-Flow path of the March 19, 1982, eruption-triggered flood and subsequent debris flow. Flow transformation to debris flow occurred on the north flank of the volcano (the Steps). Subsequently, the debris flow transformed into a hyperconcentrated water flood farther downstream. Map traced from uncorrected aerial photographs. 


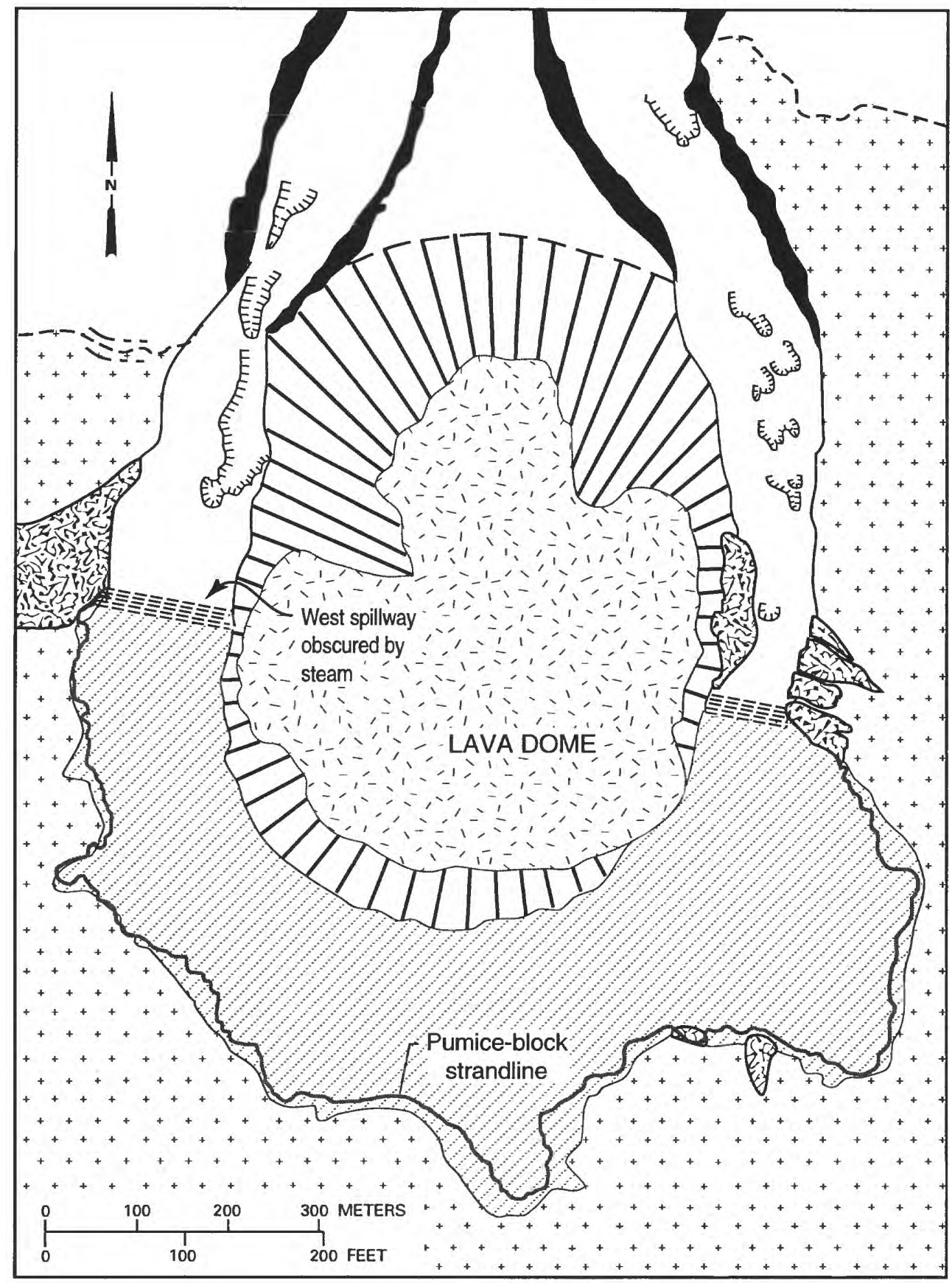

EXPLA N A I I N

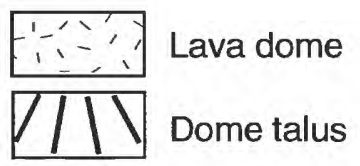

Mixed-avalanche deposit

ミsミs: Spillway location
Transient lake (maximum extent) $\because \ldots$ Crater wall darkened by

स.

Cataract headcuts in channel

FIGURE 2.2.-Position of highest transient-lake level, as interpreted from pumice-block strandlines and other shoreline features mapped from aerial photography of March 23, 1982. 
up to $100 \mathrm{~m}$ in diameter formed in the snowpack beneath these deposits.

\section{TRANSIENT-LAKE BREAKOUT}

The transient lake drained approximately simultaneously through two vertically sided outlet channels up to 30-m deep on either side of the lava dome. The lack of physical evidence for the formation of natural dams suggests that the lake formed by hydraulic ponding - meltwater was supplied faster than it could drain out (Waitt and others, 1983). However, outflow was probably hindered significantly by floating pumice blocks, which may have jammed in the outlets. There were remnants of meters-thick subaerial pumice deposits preserved immediately above both outlets (Fig. 2.2), the lower parts of which were eroded away by lake outflow. Above $3-5 \mathrm{~m}$ of relatively dense volcanic deposits on the lake-floor were 1-3 $\mathrm{m}$ of rounded, openwork, very low-density pumice blocks, which had floated on the lake surface (Waitt and others, 1983). Rounding was apparently accomplished by abrasion during jostling while floating. Outflow through the spillways must have been at least partly impeded by rafts of interlocking pumice blocks several meters thick. Slush from descending snow avalanches also may have decreased the fluidity of the outflow (Waitt and others, 1983). In addition, some water percolated into and through the crater-floor snowpack, exiting at the east and west outlets through tunnels in the snow. Strandlines of pumice blocks also formed at levels lower than 1,938-1,942 m, indicating that drainage of the transient lake was not steady.

\section{DISCHARGE ESTIMATION}

Transient-lake breach geometry was determined from a large-scale topographic map (scale 1:2,000, 2-m contour interval) drawn from June 23, 1982 aerial photography and from low-level aerial photographs taken four days after the eruption. Cross sections of the outlets were intermediate in shape between triangles and trapezoids; the east breach had a top width of about 135 $\mathrm{m}$, a bottom width of about $15 \mathrm{~m}$, and a height of about $10 \mathrm{~m}$, and the west breach had a top width of about 158 $\mathrm{m}$, a bottom width of, at most, $50 \mathrm{~m}$, and a height of about $7 \mathrm{~m}$. Discharge equations for triangular and for trapezoidal breaches were used to bracket maximum possible discharge through the two outlets. Use of either equation infers that maximum possible instantaneous discharge can be calculated by assuming critical flow through the outlets. The trapezoidal equation used here is a general form of the broad-crested weir equation, modified for dambreaks through trapezoidal sections (Price and others, 1977; Costa, 1988):

$$
Q_{\mathrm{p}}=0.3 g^{0.5} H^{1.5}(0.4 b+0.6 T)
$$

The general equation for critical flow through triangular channels (King, 1954, p. 8-10) is:

$$
Q=0.57(g / 2)^{0.5} z H^{2.5}
$$

For both equations

$Q$ is discharge $\left(Q_{\mathrm{p}}\right.$ is maximum possible discharge),

$g$ is the acceleration of gravity,

$1 / z$ is average slope of the breach side wall,

$H$ is height of the water surface above breach base upstream from spillway prior to failure,

$b$ is the width of the breach base, and

$T$ is top width of the breach at the reservoir water level.

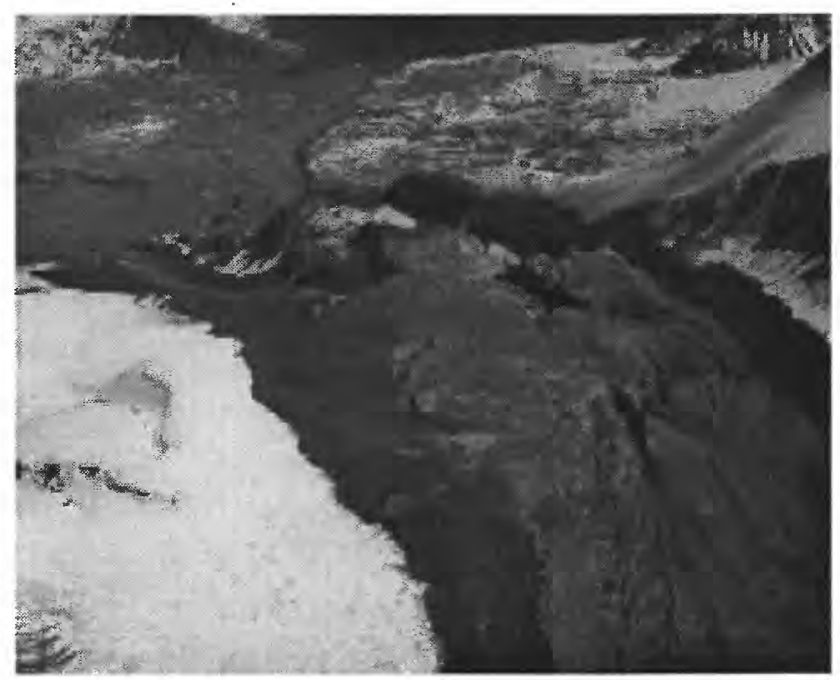

Figure 2.3.-View to the northeast out of the crater breach, where the water flood left the crater floor and entered the deeply incised ravines on the north flank. Dark bands at flow margins in foreground are mixed-avalanche deposits, which are about 500 meters apart, measuring from outer edges. The flood swath and Spirit Lake are visible in the distance. 
The two equations yielded discharges of 2,585 and 2,689 , rounded to $2,600 \mathrm{~m}^{3} / \mathrm{s}$ for flow through the east spillway, and 1,828 and 1,688 , rounded to $1,800 \mathrm{~m}^{3} / \mathrm{s}$ for flow through the west spillway. If the spillways were partly clogged by pumice blocks, initial cross-sectional dimensions may have been smaller than the final dimensions, and the computed discharges would be maximum values. Had the outflows been synchronous, maximum lake discharge would have been about $4,400 \mathrm{~m}^{3} / \mathrm{s}$, but the peak outflows from these two breaches are assumed not to have coincided, because two distinct flood surges were interpreted farther downstream. Therefore, the maximum outflow rate from the transient lake was between 2,600 and $4,400 \mathrm{~m}^{3} / \mathrm{s}$.

\section{FLOW TRANSFORMATION OF THE FLOOD}

The flood followed the path of the mixed avalanche around the dome, coalesced into a single channel, and flowed north across the crater floor and out the crater breach (figs. 2.1, 2.3, 2.4). On both sides of the dome the flood cut channels $10 \mathrm{~m}$ to $20 \mathrm{~m}$ deep and about $120 \mathrm{~m}$ wide. Trains of cataracts as much as $40 \mathrm{~m}$ deep formed in both channels. North of the dome the unified flood channel was about $200 \mathrm{~m}$ wide. While confined in the crater (average gradient $0.164 \mathrm{~m} / \mathrm{m}$ ), the flood incorporated much of the avalanche deposit, the preeruption snowpack, and the crater-floor deposits that it scoured, but it remained a water flood, as evidenced by deposit sedimentology.

\section{CHANNEL ENVIRONMENT FOR FLOW TRANSFORMATION}

After exiting the crater, the flood split again and entered two deeply incised and slightly steeper channels (average gradient $0.184 \mathrm{~m} / \mathrm{m}$ ), that guided it down the north flank of the volcano, still largely following the avalanche path (figs. 2.1, 2.5, 2.6). The small canyon on the east side of the flow path, Loowit Ravine, was completely overwhelmed by the flood, and the channel

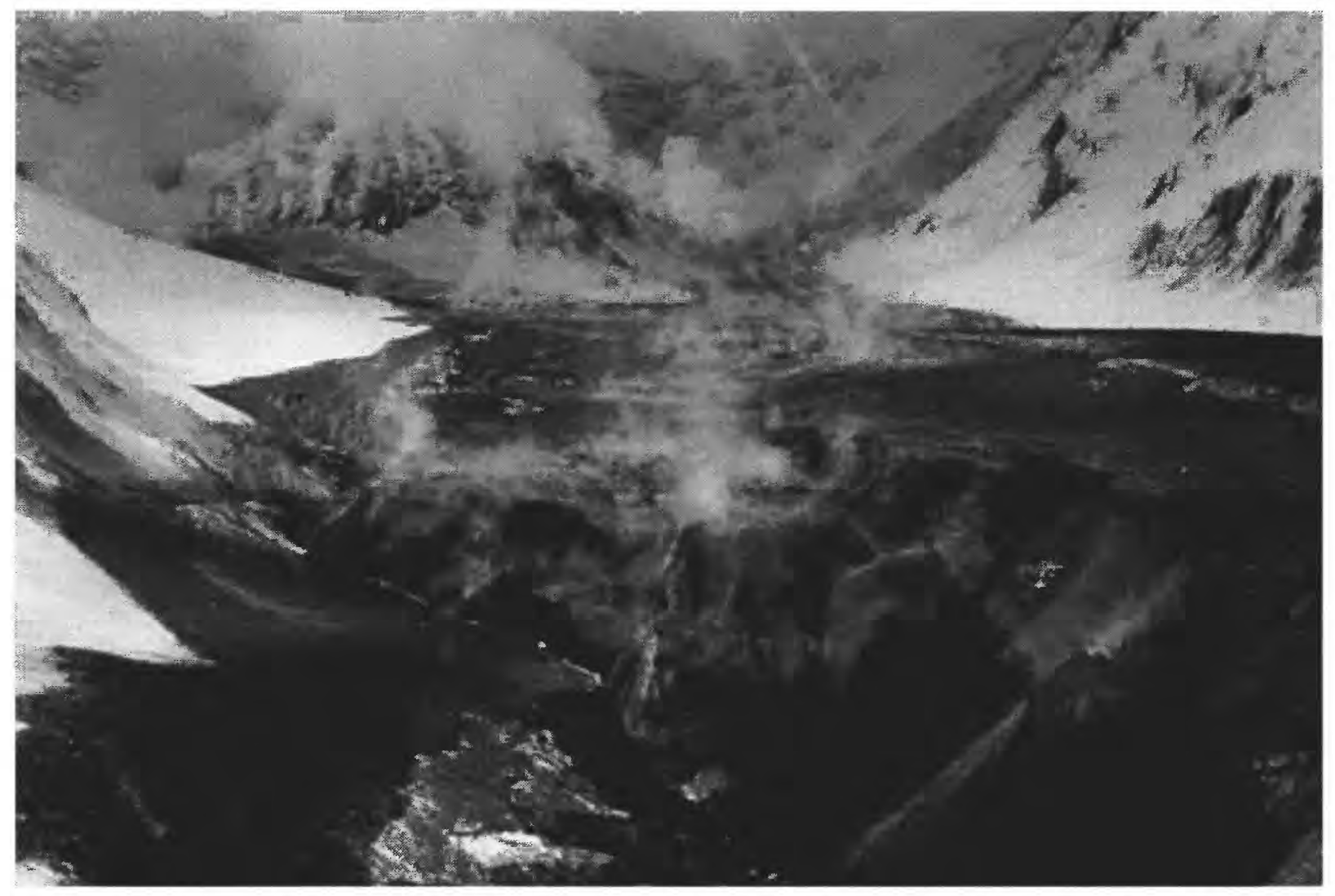

FigURE 2.4.-View south into crater from head of Loowit Ravine. Lava dome, west spillway of transient lake (berween dome and crater wall), and part of the darkened (eroded) rear crater wall are visible. Crater-floor flood channel visible in foreground. Flood and avalanche swath is about 500 meters wide. 


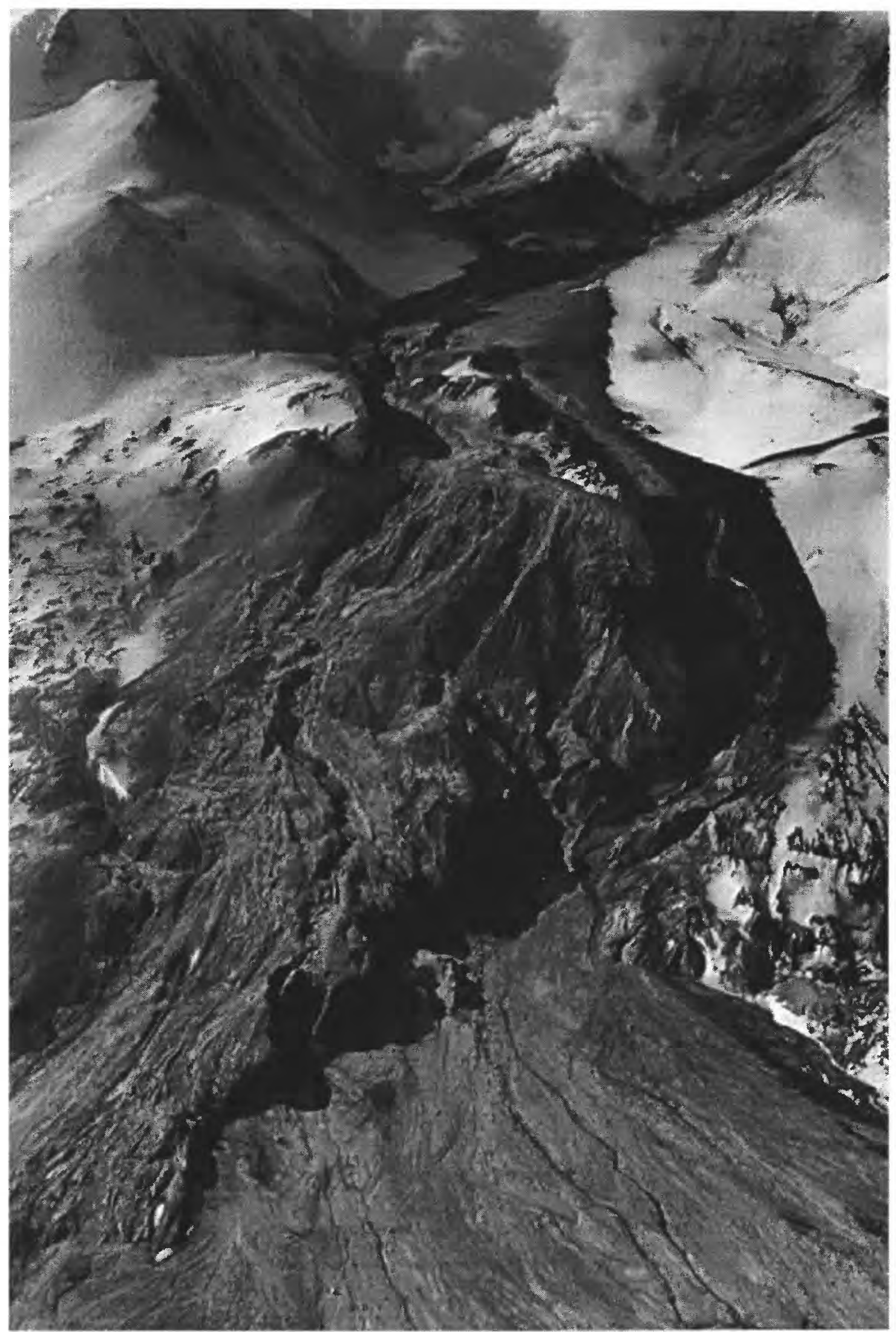

Figure 2.5.-Oblique aerial view (looking south) of the crater floor and breach, the eroded topography of the volcano's lower north flank (the Steps), and the head of the Pumice Plain (Step Fan). Flood and avalanche swath on crater floor is about 500 meters wide. 
and a wide swath of surrounding ground surface were scoured. Step Ravine, on the west side, carried a large part of the mixed avalanche but only a small fraction (probably less than 10 percent) of the flood.

The first kilometer of Loowit Ravine has a gradient of $0.141 \mathrm{~m} / \mathrm{m}$ and is deeply and narrowly incised in unconsolidated volcaniclastic deposits. Ravine sides are $50 \mathrm{~m}$ to $70 \mathrm{~m}$ high and almost continuously steeper than $45^{\circ}$, which means they are steeper than the angle of repose of the material. Post-flood reconnaissance indicated that massive bank failures occurred in this reach during the flood. On exiting the deeply incised reach, much of the flow then plunged over a 70 -m-high waterfall and continued down a less deeply incised channel (gradient $0.149 \mathrm{~m} / \mathrm{m}$ ). In this lower reach of Loowit Ravine, flow continued to scour and spilled over into the lower end of
Step Ravine. For the entire length of Loowit Ravine, channel banks ranged from about $10 \mathrm{~m}$ to $70 \mathrm{~m}$ high, and for at least 74 percent of its length, banks were steeper than $45^{\circ}$. The largest share of incorporated sediment probably came from mass failures of these high, steep banks.

At the head of the pyroclastic debris fan (Pumice Plain) where both ravines debouched (fig. 2.1), characteristic debris-flow deposits were present instead of fluvial gravels, indicating that flow transformation had occurred over a distance of only $2.7 \mathrm{~km}$. Lithologically and texturally distinct depositional units, Unit 1 and Unit 2 (figs. 2.7, 2.8), were in sharp contact wherever they occurred together. The units are inferred to have been deposited by two separate flow pulses (Flow 1 and Flow 2), which are assumed to have originated from
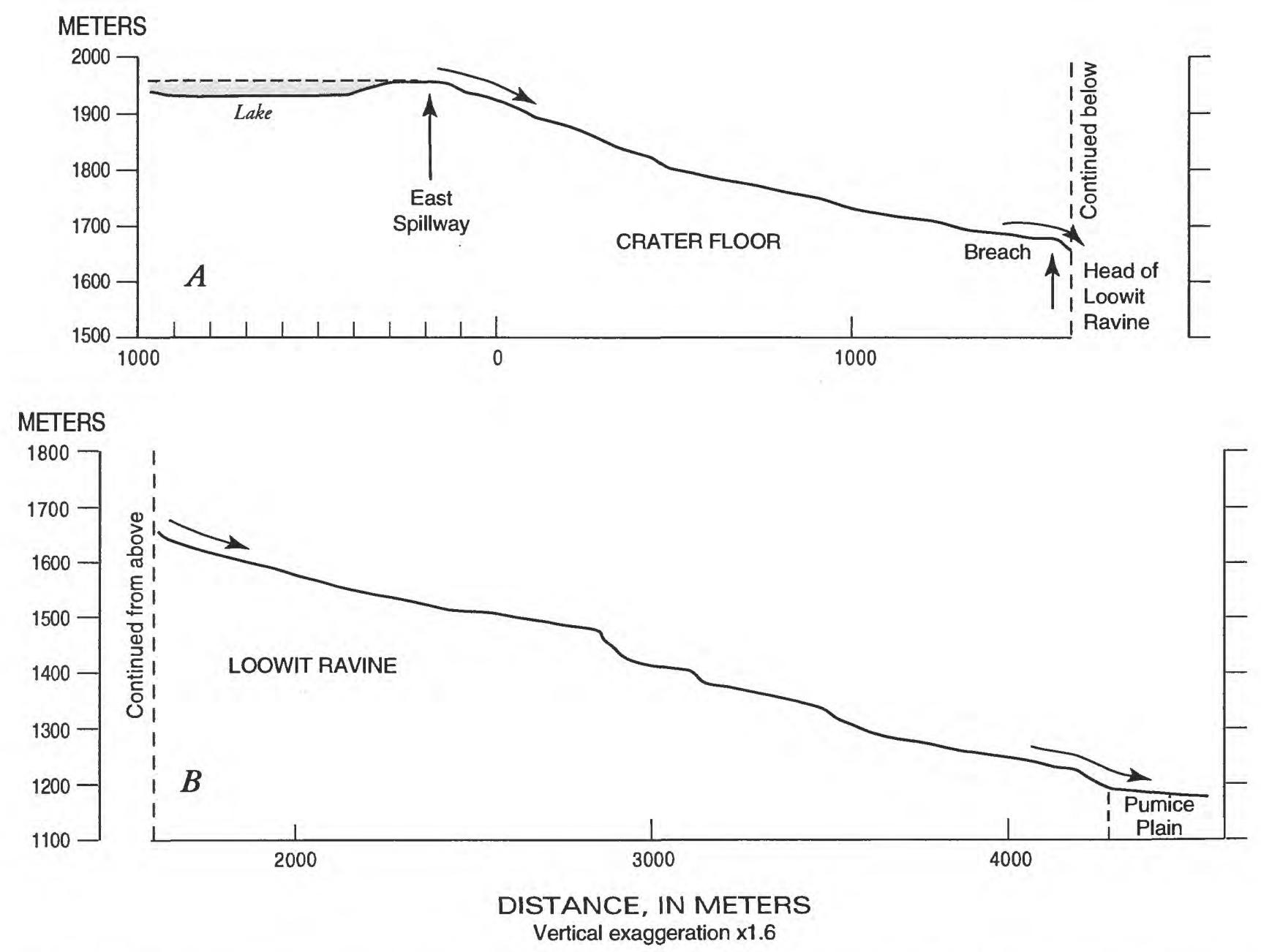

FIGURE 2.6.-Longitudinal profile of flood flow path: $A$, on crater floor (from east spillway to head of Loowit Ravine) and $B$, continuation of $A$ on north flank of the volcano (along axis of Loowit Ravine). 


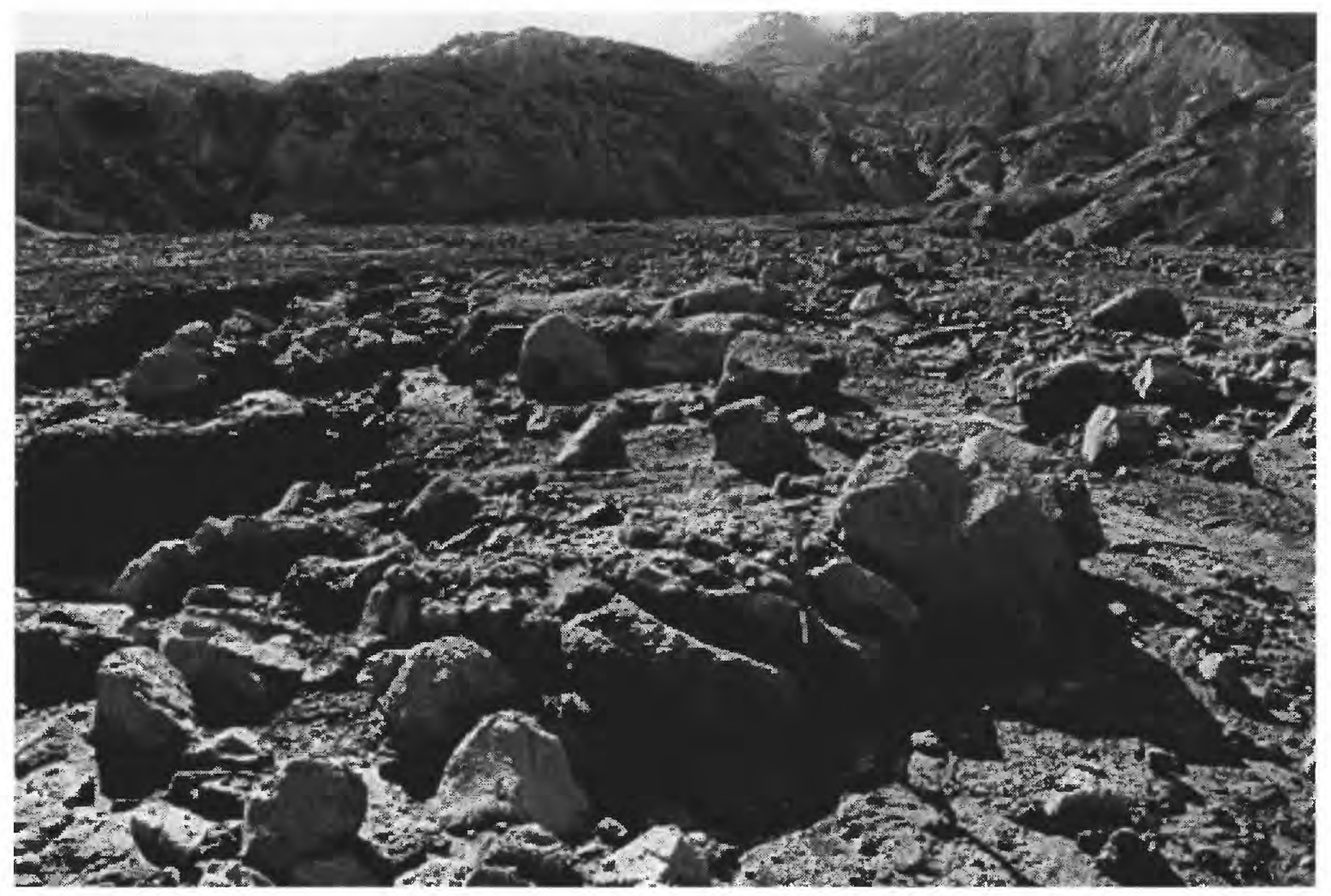

Figure 2.7.-Unit 1 debris-flow deposit at head of Pumice Plain, about 6 kilometers downstream from flood source. Shovel ( 75 centimeters long) is resting against a flow lobe, a primary debris-flow depositional feature.

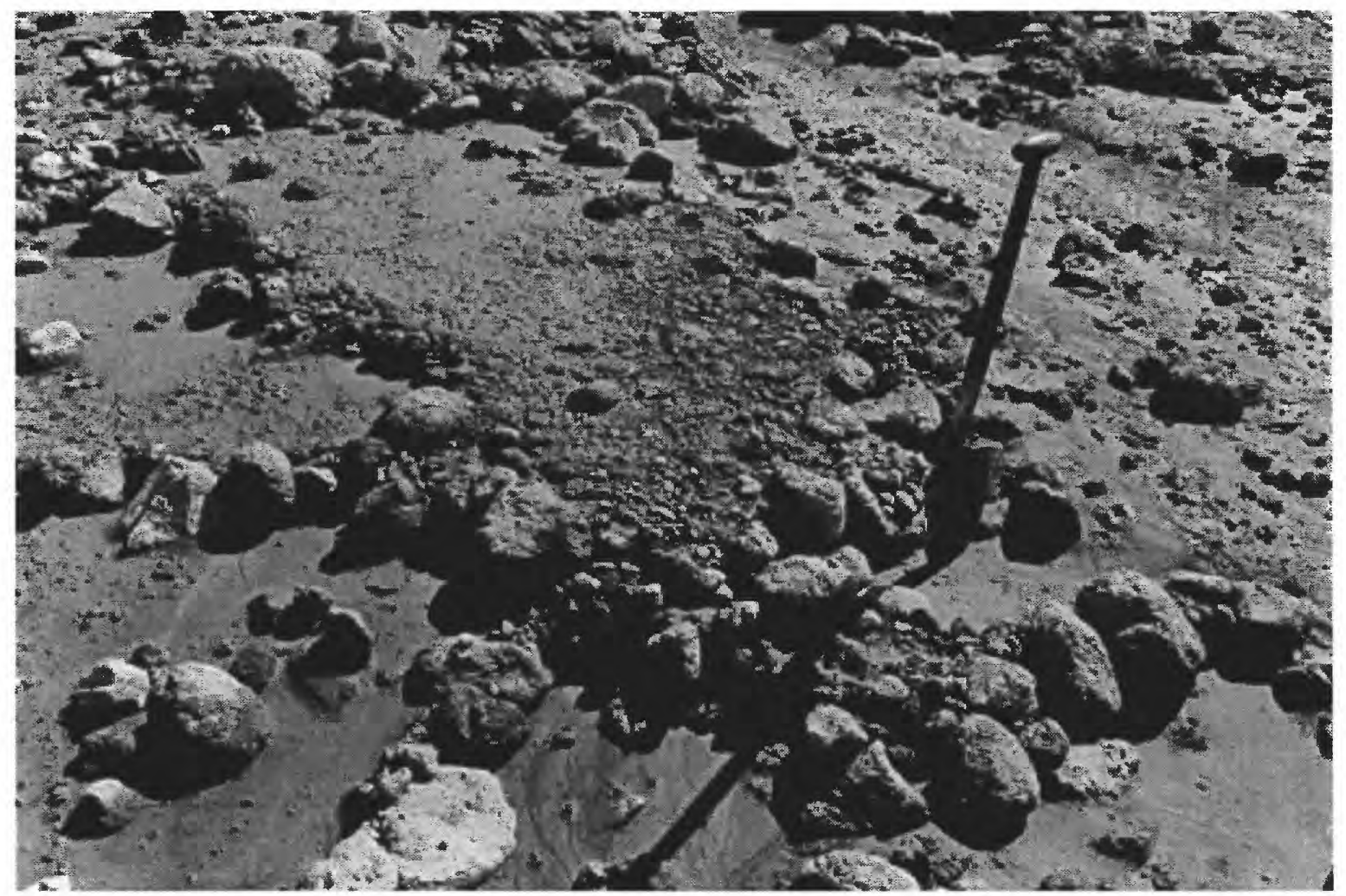

Figure 2.8.-Lobe of Unit 2 debris-flow deposit at head of Pumice Plain. Shovel is 75 centimeters long. 
unsynchronized breaching of the transient lake through the two outlets. Flow 1 descended both ravines and scoured much of the lower interfluve between the ravines; Flow 2 had a smaller discharge and was confined to Loowit Ravine. When first examined in the field, less than 24 hours after deposition, the two distinct (and now frozen) debris-flow deposits overlay or cut across the mixed-avalanche deposit. The debris-flow units were, in turn, locally overlain or cut by thin fluvial deposits, which were apparently emplaced by small dilute discharges during the waning stages of the flood. This depositional sequence is typical of debris-flow tails (Pierson, 1986).

Flow exiting Step Ravine (Flow 1) left mudlines that defined a channel cross section about $230 \mathrm{~m}$ wide and about $4 \mathrm{~m}$ deep (cross section $A$, fig. 2.1), but not all the flow was conveyed past this cross section. Flow also exited Loowit Ravine, but a flow cross section was not established there. If a mean velocity of $10 \mathrm{~m} / \mathrm{s}$ is assumed for the Step Ravine section (a conservative velocity for flow of this magnitude in a steep channel, see Janda and others, 1981; Gallino and Pierson, 1985; Pierson, 1985; Pierson and others, 1990), an instantaneous discharge of $9,200 \mathrm{~m}^{3} / \mathrm{s}$ is obtained for that part of the flow. Farther out on the Pumice Plain where all of Flow 1 combined to form an irregular unconfined sheet of flowing debris roughly $1,800 \mathrm{~m}$ wide, mudlines left on remnants of the mixed-avalanche deposit indicated a flow depth of as much as $3 \mathrm{~m}$. If mean depth were $1.0 \mathrm{~m}$ and mean velocity $5 \mathrm{~m} / \mathrm{s}$ (also a conservative value for a large flow), peak discharge for Flow 1 across the upper Pumice Plain would be $9,000 \mathrm{~m}^{3} / \mathrm{s}$. These rough estimates indicate that debris-flow peak discharge was on the order of $10^{4}$ $\mathrm{m}^{3} / \mathrm{s}$ for Flow 1, at least double the maximum possible outflow discharge from the transient lake. Total volume of the debris flow as it traversed the upper Pumice Plain, assuming a sediment concentration by volume of at least 0.70 from the incorporation of eroded debris and adding this amount to the water flood (Pierson and Scott, 1985), would have been about 10.0 to $13.3 \times 10^{6} \mathrm{~m}^{3}$, approximately three times the original volume of the transient lake.

\section{SEDIMENTOLOGIC EVIDENCE FOR TRANSFORMATION TO DEBRIS FLOW}

Debris-flow sediments differ from normal fluvial sediments in their characteristic lack of stratification, poorly sorted texture, random or poorly developed clast fabric, fluid shear strength (evidenced by transportation of large clasts over low gradients and steep terminal lobes), and boulder levees (Costa, 1984). These criteria were largely met in the deposits present on the Pumice Plain (Pierson and Scott, 1985). The differences between the two deposits also provide evidence for two distinct flow pulses (fig. 2.9).

The stratigraphically lower Pumice Plain deposit (Unit 1) was a dark- to medium-gray, muddy, sandy gravel consisting predominantly of lithic (nonvesicular) volcanic rock debris. Sampled deposits (excluding clasts $>64 \mathrm{~mm}$ ) were unstratified, ungraded, and very poorly sorted $\left(\sigma_{\mathrm{I}}>3.0 \phi\right)$. Unit 1 was deposited as a 10 - to 50 -cm-thick sheet over much of the Pumice Plain (average gradient $0.04 \mathrm{~m} / \mathrm{m}$ ), but boulders as large as $2 \mathrm{~m}$ in diameter were stranded on broad areas of this fan (Pierson and Scott, 1985), which was evidence that the flow depth was greater than the deposit thickness. Lobate flow fronts and boulder levees were preserved on the west edge of the Pumice Plain where this unit was not overridden by Flow 2. Similarities in color and lithology between Unit 1 and the mixed-avalanche deposit indicate that the first flood surge from the crater obtained much of its sediment load by remobilizing the mixed-avalanche deposit that lay in its path.

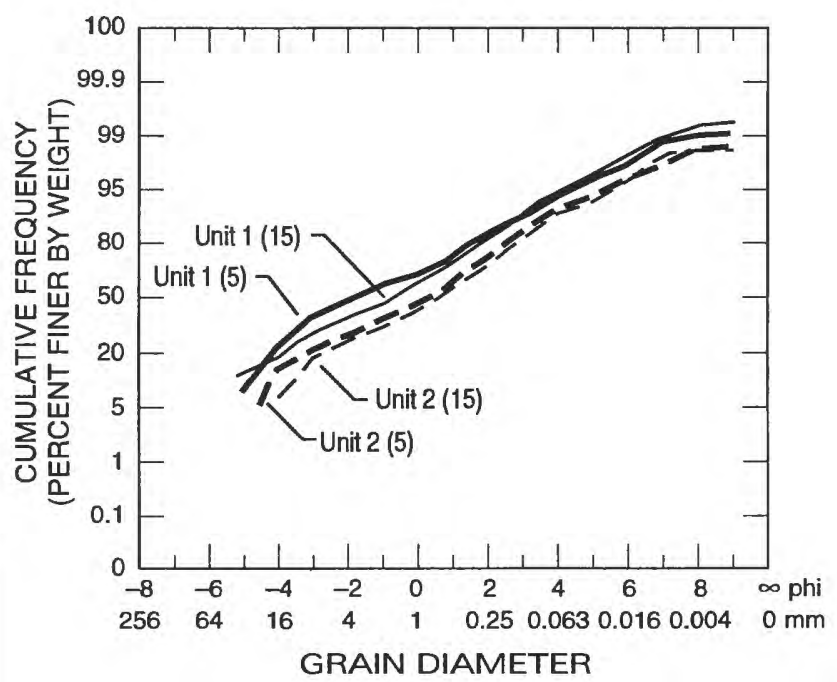

Figure 2.9.-Cumulative frequency curves of samples of debris-flow deposits (clasts larger than 64 millimeters not sampled) from upper North Fork Toutle River. Numbers in parentheses are distances in kilometers from transient lake in the crater. Y-axis is normal probability scale. Grain diameter in phi units is the negative logarithm to base 2 of grain diameter in millimeters. 
The second Pumice-Plain deposit (Unit 2) was a grayish brown, pumice-rich, muddy, gravelly sand, having more fine material in its matrix than Unit 1 (fig. 2.9). Like Unit 1 , sampled deposits (excluding clasts $>64 \mathrm{~mm}$ ) were unstratified, ungraded, and very poorly sorted. Unit 2 was generally thinner $(5$ to $20 \mathrm{~cm}$ ) than Unit 1 , but the flow that deposited it also had sufficient depth and competence to transport numerous boulders (fig. 2.10). Pumice fragments in this deposit were mostly yellowish brown, weathered clasts that had been scoured from the crater floor and north-flank channels.

\section{CONTINUED EROSION AND BULKING BY DEBRIS FLOW}

Average erosion measured over two North Fork Toutle River channel cross sections on the Pumice Plain (LO030 and LO040) was $0.5 \mathrm{~m}$ and $1.2 \mathrm{~m}$ net scour (table 2.1). Where debris flow was unconfined, significant erosion did not occur (fig. 2.10), but where flow was confined, it incised the pumiceous fan deposits and formed steep-sided gullies (fig. 2.11). Parts of both debris flows entered Spirit Lake (fig. 2.1); the rest followed anastomosing channels down the North Fork Toutle River valley. The multiple channels eventually coalesced about $13 \mathrm{~km}$ downstream.

Peak flow depths (Flow 1) in the North Fork Toutle River channel from $13 \mathrm{~km}$ to $26 \mathrm{~km}$ downstream from the crater ranged from about $4 \mathrm{~m}$ to $8 \mathrm{~m}$, and net downcutting of the channel (with no widening) averaged about $1 \mathrm{~m}$ to $3 \mathrm{~m}$ (table 2.1), locally exceeding $6 \mathrm{~m}$ (fig. 2.12). Along this reach, which has an average gradient of 0.020 , the North Fork Toutle River channel was incised into the highly erodible 1980 debrisavalanche deposit (Voight and others, 1983; Pierson and Scott, 1985). Peak flow velocities, indirectly computed using superelevations at two cross sections at the upper

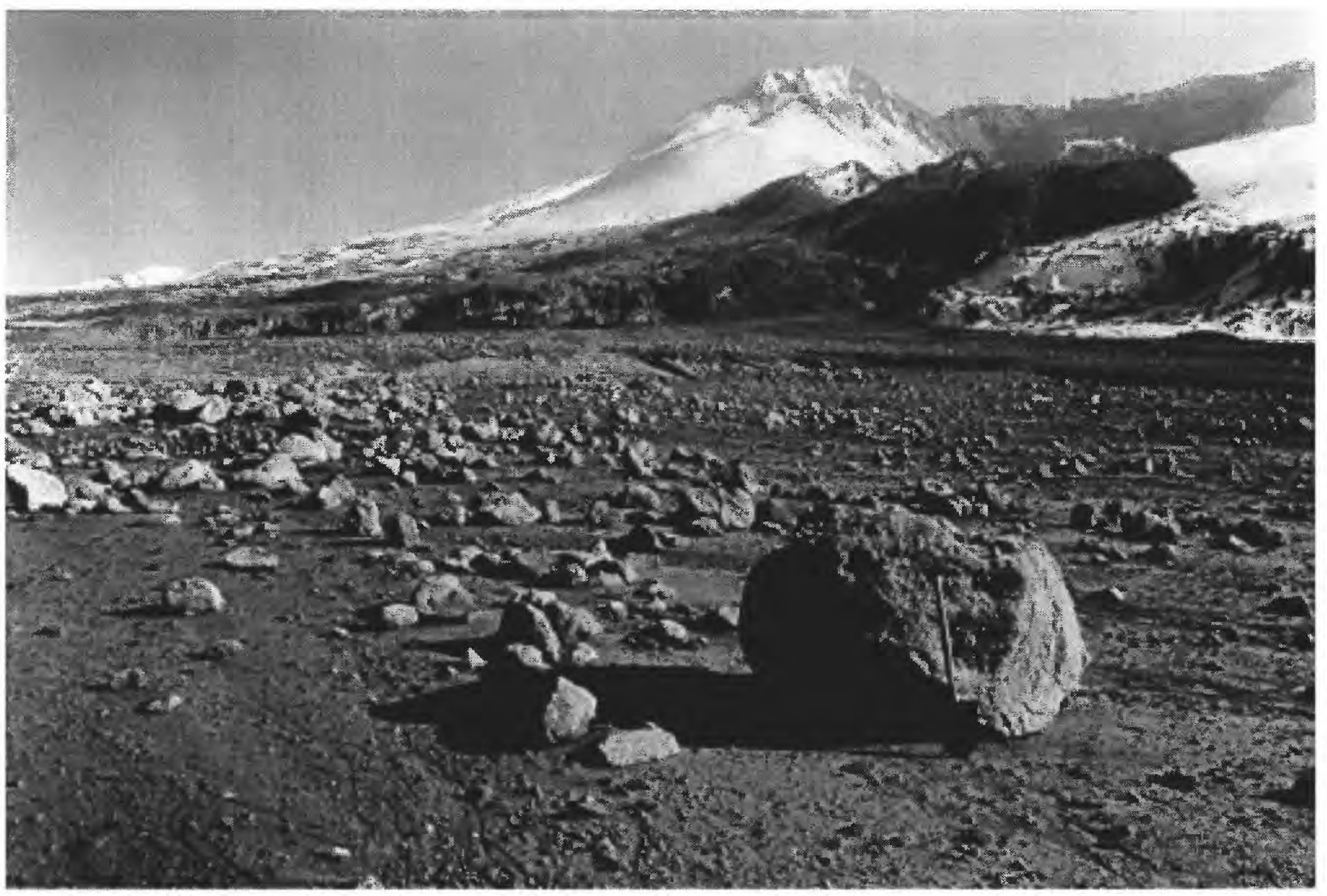

FIGURE 2.10.-Thin (few centimeters thick) Unit 2 debris-flow deposit on lower Pumice Plain; boulders stranded when finer-grained slurry continued flowing downstream. Shovel is 75 centimeters long. 
TABLE 2.1.-Erosion index values (positive = net erosion) for monumented cross sections on the North Fork Toutle River. Cross-sectional area changes computed from preeruption surveys in early March and again following the eruption on March 20, 1982

[Data supplied by D.F. Meyer, U.S. Geological Survey.]

\begin{tabular}{ccccc}
\hline Cross section & $\begin{array}{c}\text { Channel distance } \\
\text { downstream from } \\
\text { crater (kilometers) }\end{array}$ & $\begin{array}{c}\text { Channel width } \\
\text { (meters) }\end{array}$ & $\begin{array}{c}\text { Change in } \\
\text { cross section area } \\
\text { (square meters) }\end{array}$ & $\begin{array}{c}\text { Erosion index } \\
\text { (meters) }\end{array}$ \\
\hline LO 030 & 4.2 & 538 & 618 & 1.2 \\
LO 040 & 6.4 & 238 & 122 & $0.5^{2}$ \\
NF 130 & 15.7 & 111 & 313 & 2.8 \\
NF 310 & 21.1 & 424 & 688 & 1.6 \\
NF 320 & 22.5 & 280 & 455 & 1.6 \\
NF 350 & 25.1 & 486 & 104 & 0.2 \\
\hline
\end{tabular}

2 This channel carried only a minor part of the flow, so value not directly comparable to other cross sections, which carried all the flow.

end of the reach, were $8.5 \mathrm{~m} / \mathrm{s}$ and $10.0 \mathrm{~m} / \mathrm{s}$. Although peak flow decreased through this reach from $6,800 \mathrm{~m}^{3} / \mathrm{s}$ to $3,700 \mathrm{~m}^{3} / \mathrm{s}$ (Pierson and Scott, 1985), total volume (both flows) increased to about 1.1 to $1.9 \times 10^{7} \mathrm{~m}^{3}$, nearly five times the original lake outflow volume (R.J. Janda, U.S. Geological Survey, written commun., 1983; Pearson, 1986, p. 90) as the flows continued to bulk up with eroded wet sediment. Along this entire reach, Units 1 and 2 were separated by a sharp stratigraphic contact and maintained distinctive textural differences (fig. 2.13).

Downstream from the toe of the 1980 debrisavalanche deposit, flow entered the catch basin of the $\mathrm{N}-1$ sediment dam (fig. 2.1), which induced deposition of about $7.7 \times 10^{6} \mathrm{~m}^{3}$ of debris slurry (Pearson, 1986, p. 90). From that point on, the remaining debris flow (mostly Flow 2) began to transform through dilution to hyperconcentrated streamflow (Waitt and others, 1983; Pierson and Scott, 1985).

\section{FACTORS FOR TRANSFORMATION TO DEBRIS FLOW}

For flowing water to increase its volumetric sediment concentration from less than 0.20 to 0.65 or more and, thus, become a debris flow, a number of conditions must be satisfied: (1) enough sediment, in proportion to available water, must be available for incorporation; (2) sediments must be sufficiently poorly sorted to trap pore water and facilitate partial liquefaction of the sediment-water mass; and (3) there must be an adequate mechanism for effectively mixing the sediment and water.

\section{FACTORS FOR THE MARCH 19, 1982 FLOOD}

On March 19, 1982, necessary and sufficient conditions for transformation of water flood to debris flow were present in the $2.7-\mathrm{km}$-long Loowit Ravine, on the north flank of the volcano (fig. 2.1). Approximately 7 to $9 \times 10^{6} \mathrm{~m}^{3}$ of sediment were added to the floodwater at a minimum average rate of $2.5 \times 10^{6} \mathrm{~m}^{3} / \mathrm{km}$ as the flood exited the crater. The added sediments were loose and very poorly sorted, and the steep channel gradient (including one large waterfall) ensured turbulent mixing. It is noteworthy that transformation did not occur along the $1.7-\mathrm{km}$-long channel still within the crater, which was actually steeper than the two individual subreaches of Loowit Ravine (0.164 compared to 0.141 and 0.149 ) and which had bed and bank material that was equally as erodible as the material in the banks in Loowit Ravine. Although the crater reach was slightly shorter than Loowit Ravine, other floods have transformed to debris flows along an even shorter channel reach at Mt. Rainier (table 2.2).

The key differences, between reaches that induce transformation of water flow to debris flow and those that do not, seem to be related to channel morphology. 


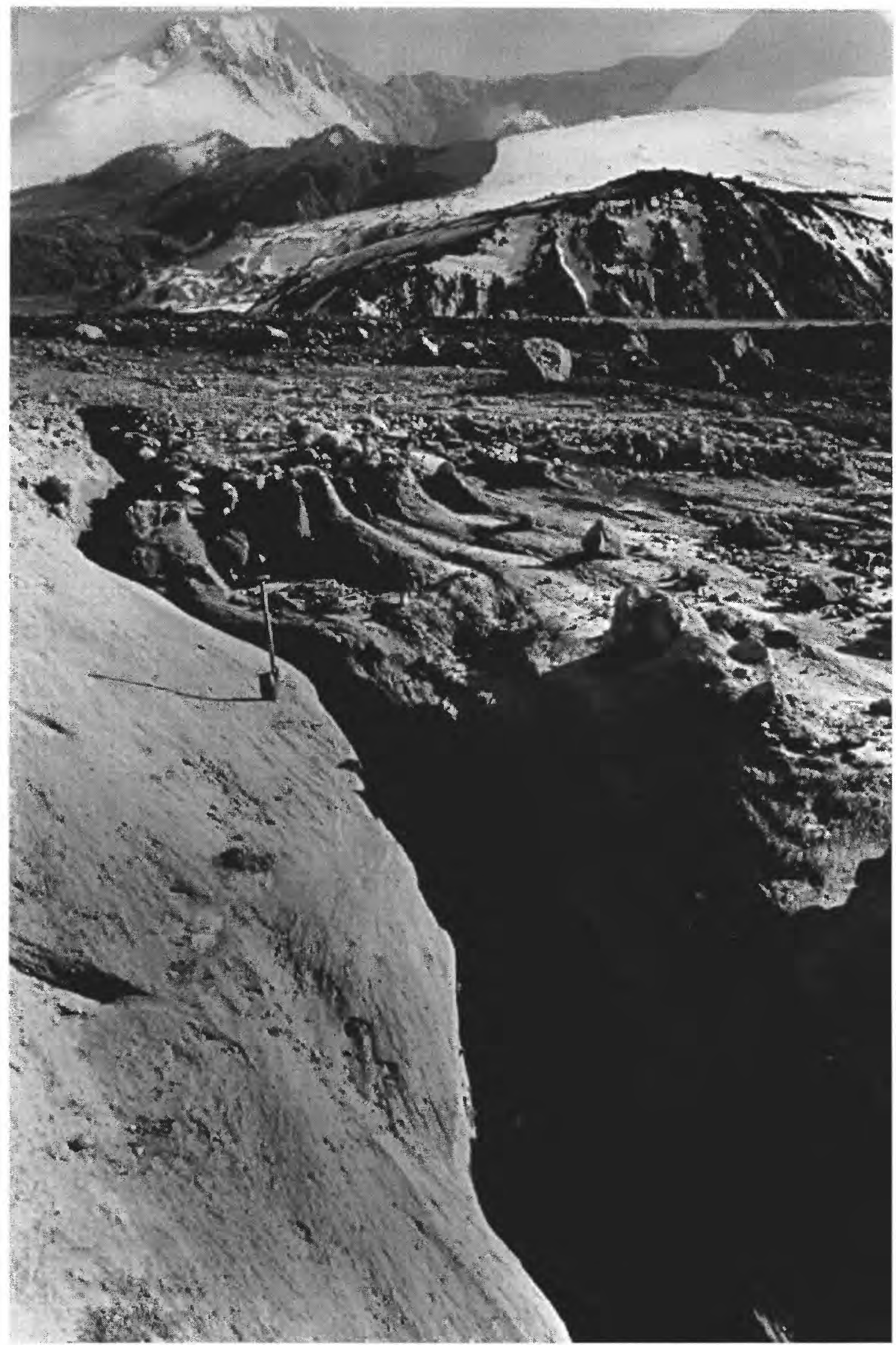

FIGURE 2.11.-Gullying left by erosion of 1980 pumiceous pyroclastic-flow deposits by debris flow on the lower Pumice Plain. Shovel is 75 centimeters long. 
TABLE 2.2.-Characteristics of flood channels at Mount St. Helens and Mount Rainier, where water floods have transformed to debris flows

\begin{tabular}{|c|c|c|c|c|c|c|}
\hline Event & $\begin{array}{l}\text { Approximate } \\
\text { peak Q } \\
\text { (cubic meters } \\
\text { per second) }\end{array}$ & $\begin{array}{l}\text { Reach } \\
\text { length } \\
\text { (meters) }\end{array}$ & $\begin{array}{l}\text { Reach } \\
\text { gradient } \\
\text { (meters per } \\
\text { meter) }\end{array}$ & $\begin{array}{c}\text { Bed/bank } \\
\text { material }\end{array}$ & $\begin{array}{c}\text { Average } \\
\text { bank height } \\
\text { (meters) }\end{array}$ & $\begin{array}{c}\text { Bank } \\
\text { conditions }\end{array}$ \\
\hline $\begin{array}{l}\text { Mount St. Helens, } \\
3-19-82 \text {, } \\
\text { Loowit Ravine }\end{array}$ & $\begin{array}{l}1500- \\
4500\end{array}$ & 2,670 & 0.184 & $\begin{array}{l}\text { Unconsolidated } \\
\text { gravelly sand }\end{array}$ & $10-70$ & $\begin{array}{l}74 \text { percent } \\
\text { of reach has } \\
\text { banks steeper } \\
\text { than } 45^{\circ}\end{array}$ \\
\hline $\begin{array}{l}\text { Mount St. Helens, } \\
2-4-83 \text {, } \\
\text { Loowit Ravine }\end{array}$ & $\begin{array}{l}<500 \\
\text { (est.) }\end{array}$ & 2,670 & 0.184 & $\begin{array}{l}\text { Unconsolidated } \\
\text { gravelly sand }\end{array}$ & $10-70$ & $\begin{array}{l}\text { Same as } \\
3-19-82\end{array}$ \\
\hline $\begin{array}{l}\text { Elk Rock dam- } \\
\text { break flood, } \\
8-27-80\end{array}$ & 450 & 6,500 & 0.027 & $\begin{array}{l}\text { Unconsolidated } \\
\text { gravelly sand }\end{array}$ & $40-60$ & $\begin{array}{l}80 \text { percent of } \\
\text { reach for first } \\
2 \mathrm{~km} \text { has } \\
\text { banks steeper } \\
\text { than } 45^{\circ}\end{array}$ \\
\hline $\begin{array}{l}\text { Mr. Rainier, } \\
\text { Tahoma Creek, } \\
7-26-88\end{array}$ & 550 & $-1,000$ & 0.14 & $\begin{array}{l}\text { Unconsolidated } \\
\text { sandy gravel, } \\
\text { locally ice-cemented }\end{array}$ & $20-30$ & $\begin{array}{l}\text { Banks near } \\
\text { vertical }\end{array}$ \\
\hline
\end{tabular}

Loowit Ravine was deeply incised, having bank heights that ranged from 10 to $70 \mathrm{~m}$ overall and that were higher than $50 \mathrm{~m}$ along most of the first $1,000 \mathrm{~m}$. Channel narrowness, relative to the discharge of flow passing through, allowed the flood to undercut and destabilize both banks. More than 74 percent of the total reach length (and almost all of the first $1,000 \mathrm{~m}$ ) had banks of unconsolidated volcaniclastic deposits that had slopes steeper than $45^{\circ}$. This steepness means that the slopes were very susceptible to mass failure when undercut. Post-flood reconnaissance revealed that numerous bank failures had occurred. In contrast, the channel in the crater floor was 10 to $40 \mathrm{~m}$ deep but offered fewer unstable banks and little bank erosion occurred there. Large-scale mass failure of the high, oversteepened channel banks in Loowit Ravine seems to have been critical in transforming the water flood to debris flow. Temporary ponding of flow by bank collapses may have occurred, as has been inferred for debris-flow transformations at Mt. Shasta (Osterkamp and others, 1986), but because of the steep channels and high discharge, any such ponding could only have been momentary.

\section{FACTORS FOR OTHER FLOW EVENTS}

Three other examples of transformation from water flood to debris flow at Mount St. Helens and Mt. Rainier have occurred within the last decade (table 2.2), and high, unstable channel banks seem to have been important at these sites, as well. Peak discharges and channel gradients were variable and not particularly high, so especially steep channels or anomalously high flood discharges apparently were not required to effect the transformation. All the reaches did have poorly sorted, unconsolidated bed and bank materials that were highly erodible, and the channels were cut in recent, unvegetated materials. Additionally, all of the reaches had narrow cross sections 
that had high $(>20 \mathrm{~m})$, oversteepened $\left(>45^{\circ}\right)$ banks. High flows in these channels impinged upon and destabilized the banks, causing large volumes of sediment to collapse into the channels.

\section{MOUNT ST. HELENS CRATER-LOOWIT RAVINE, SMALLER DISCHARGE}

A much smaller water flood generated by an explosive eruption in February 1983 (Pierson and Waitt, chap. 4, this volume) followed the same flow path as did the flood of March 19, 1982 (table 2.2). This flood, that had a peak discharge of probably a few hundred cubic meters per second, remained a water flood in the crater reach and transformed to a debris flow in Loowit Ravine. However, the debris-flow volume was so small that the

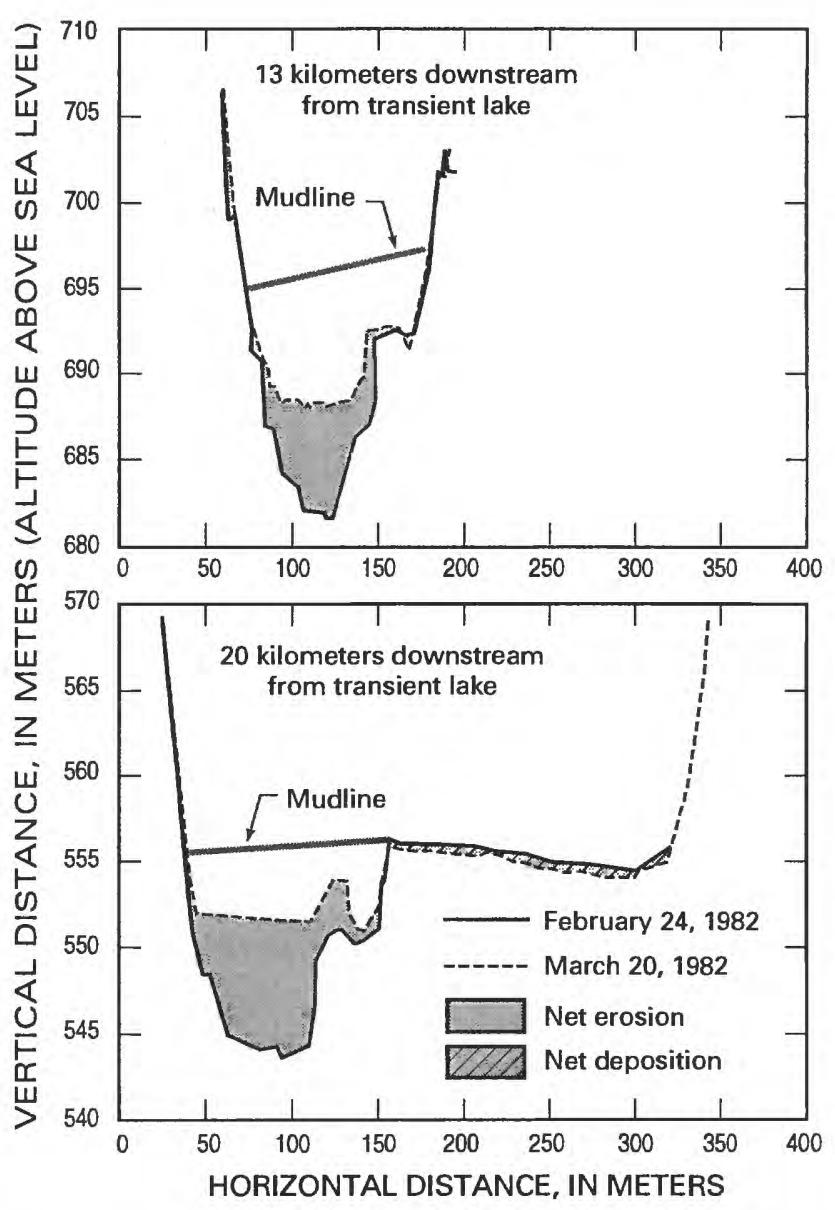

FigURE 2.12.-Cross sections of North Fork Toutle River channel where it is cut into the 1980 debris-avalanche deposit at distances of about 13 kilometers and 20 kilometers downstream from the transient lake. Average gradient between the cross sections is 0.020 . flow did not travel beyond the Pumice Plain.

\section{NORTH FORK TOUTLE RIVER VALLEY- BREAKOUT OF SMALL LANDSLIDE-DAMMED LAKE}

Near the downstream end of the 1980 debrisavalanche deposit, Elk Rock Lake breached on August 27, 1980 and produced a flood wave that was hyperconcentrated (volumetric sediment concentration 42 percent) $30 \mathrm{~km}$ farther downstream (Randy Dinehart, U.S. Geological Survey, written commun., 1980). The flood wave almost certainly reached debris-flow concentration initially. Peak discharge at the spillway was estimated to have been $450 \mathrm{~m}^{3} / \mathrm{s}$ (table 2.2) (Jennings and others, 1981). The flood started by flowing down a narrow, 2-km-long, 0.027-gradient channel reach, where more than 80 percent of the channel banks were 40 to $60 \mathrm{~m}$ high and steeper than $45^{\circ}$.

\section{MT. RAINIER-GLACIER-OUTBURST FLOODS}

Glaciers at Mt. Rainier have long been producing glacier-outburst floods that transform to debris flows (Richardson, 1968; Driedger and Fountain, 1989). One that originated from South Tahoma Glacier on July 26, 1988 (Walder and Driedger, 1994) had a peak discharge of about $550 \mathrm{~m}^{3} / \mathrm{s}$ at a point several kilometers downstream from the glacier (table 2.2). Transformation occurred in a 1-km-long, 0.14-gradient reach bounded by 20 - to $30-\mathrm{m}$-high, near-vertical banks consisting of partly ice-cemented glacial till .

\section{SUMMARY AND CONCLUSIONS}

The March 19, 1982, explosive eruption at Mount St. Helens produced a prodigious volume of meltwater in a matter of tens of minutes. The topography of the crater floor, combined with the eruption of a large amount of low-density pumice, created a situation where meltwater was accumulated and then released in two major flood waves. After flowing out of the crater, the meltwater flood waves transformed to debris flows in a steep, narrow, 2.7-km-long channel reach on the north flank of the volcano. During the transformation, peak discharge and flow volume more than doubled. Once transformed, the debris-flow flood (still in two separate flood waves) continued to erode and bulk up in volume 

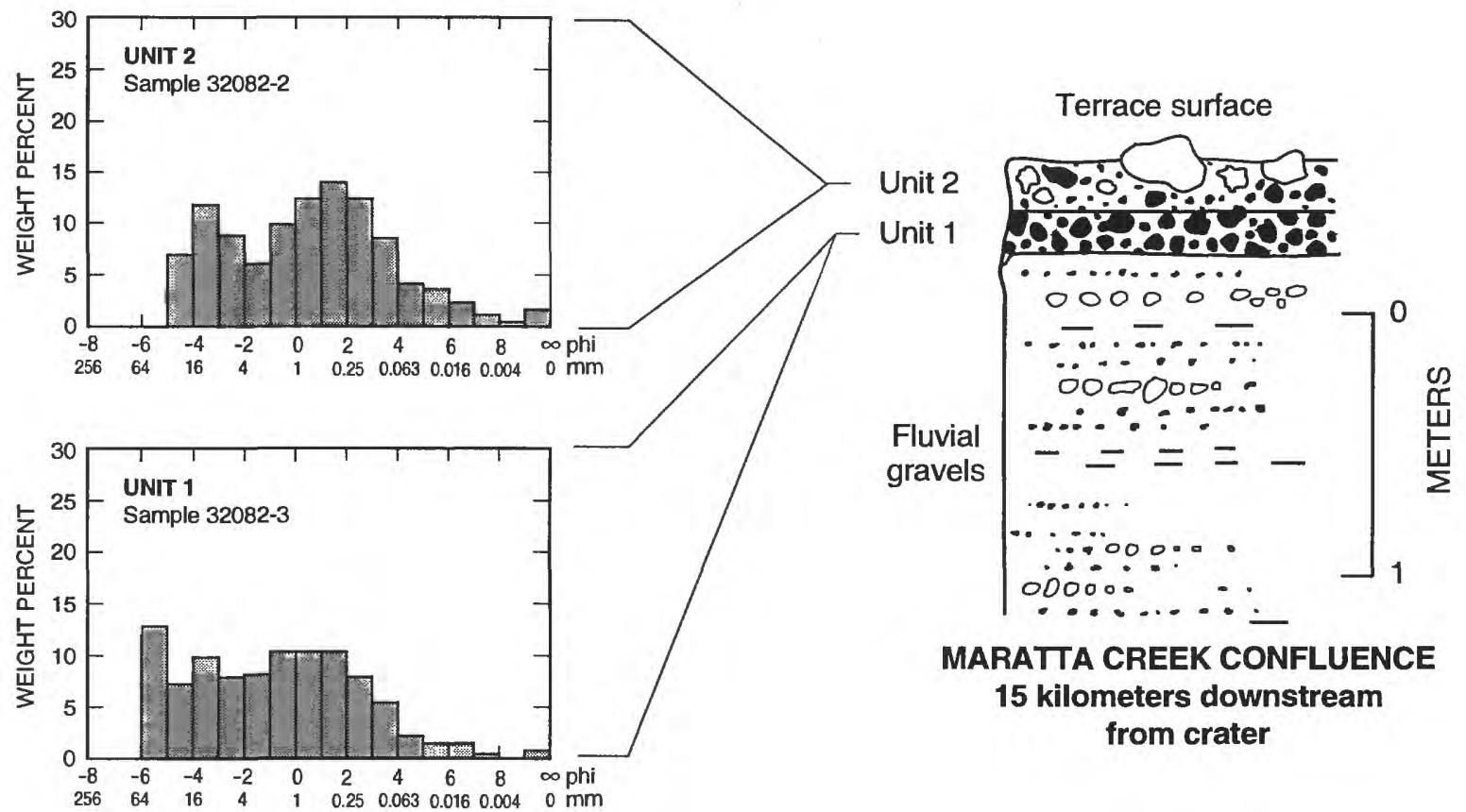

\section{MARATTA CREEK CONFLUENCE 15 kilometers downstream from crater}
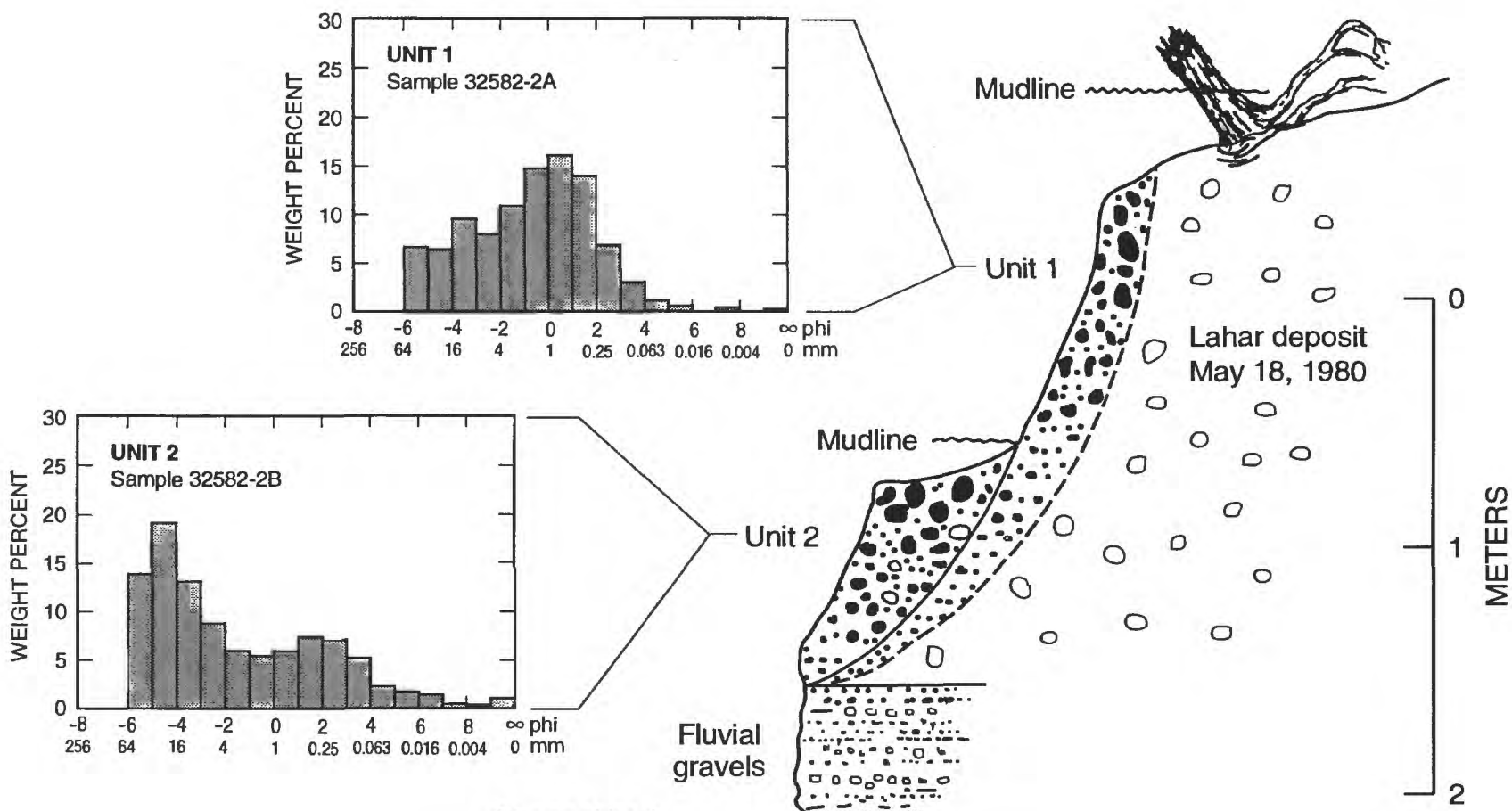

Channel bed March 25, 1982

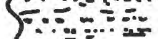

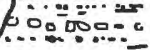

NEAR TOE OF DEBRIS-AVALANCHE DEPOSIT 28 kilometers downstream from crater

FiguRE 2.13.- Stratigraphic relations of Unit 1 to Unit 2 at distal end of channel reach carrying debris flow. Histograms of sample matrix and small-clast grain-size distributions are shown; clasts larger than 64 millimeters not sampled. 
for the next $25 \mathrm{~km}$, eventually reaching a flow volume roughly 5 times that of the initial flood.

The March 19, 1982 water flood transformation to debris flow is one of several to have occurred at northwest volcanoes in the last decade. Not all of these other cases occurred in especially steep channels and none had large $\left(>500 \mathrm{~m}^{3} / \mathrm{s}\right)$ discharges. But, like the March 19, 1982 flood, all of them did occur after the initial water floods passed through narrow channel reaches bounded by high $\left(>20 \mathrm{~m}\right.$ ), oversteepened $\left(>45^{\circ}\right)$ banks consisting of poorly sorted, unconsolidated, and unvegetated deposits. Therefore, channels that have such morphology and bank materials may be prime sites for transformation of water floods to debris flows.

\section{ACKNOWLEDGMENTS}

This study has benefitted from numerous discussions with U.S. Geological Survey colleagues at the Cascades Volcano Observatory. Waite Osterkamp and Jim O'Connor provided very helpful reviews of the manuscript.

\section{REFERENCES CITED}

Blown, Iain, and Church, Michael, 1985, Catastrophic lake drainage within the Homathko River basin, British Columbia: Canadian Geotechnical Journal, v. 22, no. 4, p. 551-563.

Clague, J.J., Evans, S.G., and Blown, I.G., 1985, A debris flow triggered by the breaching of a moraine-dammed lake, Klattasine Creek, British Columbia: Canadian Journal of Earth Sciences, v. 22, no. 10, p. 1492-1502.

Costa, J.E., 1984, Physical geomorphology of debris flows, in Costa, J.E., and Fleisher, P.J., eds., Developments and applications of geomorphology: Berlin, Springer-Verlag, p. 268-317.

Costa, J.E., 1988, Floods from dam failures, in Baker, V.R., Kochel, R.C., and Patton, P.C., eds., Flood geomorphology: New York, Wiley, p. 439-463.

Driedger, C.L., and Fountain, A.G., 1989, Glacier outburst floods at Mount Rainier, Washington State, U.S.A., in Wold, Bjorn, ed., Proceedings of the symposium on snow and glacier research relating to human living conditions: Annals of Glaciology, v. 13, p. 51-55.

Fisher, R.V., 1983, Flow transformations in sediment gravity flows: Geology, v. 11, no. 5, p. 273-274.
Gallino, G.L., and Pierson, T.C., 1985, Polallie Creek debris flow and subsequent dam-break flood of 1980, East Fork Hood River basin, Oregon: U.S. Geological Survey WaterSupply Paper 2273, $22 \mathrm{p}$.

Jackson, L.E., Jr., 1979, A catastrophic glacial outburst flood (jokulhlaup) mechanism for debris flow generation at the Spiral Tunnels, Kicking Horse River basin, British Columbia: Canadian Geotechnical Journal, v. 16, no. 4, p. 806-813.

Janda, R.J., Scott, K.M., Nolan, K.M., and Martinson, H.A., 1981, Lahar movement, effects, and deposits, in Lipman, P.W., and Mullineaux, D.R., eds., The 1980 eruptions of Mount St. Helens, Washington: U.S. Geological Survey Professional Paper 1250, p. 461-478.

Jennings, M.E., Schneider, V.R., and Smith, P.E., 1981, Computer assessments of potential flood hazards from breaching of two debris dams, Toutle River and Cowlitz River systems, in Lipman, P.W., and Mullineaux, D.R., eds., The 1980 eruptions of Mount St. Helens, Washington: U.S. Geological Survey Professional Paper 1250, p. 829-836.

King, H.W., 1954, Handbook of hydraulics for the solution of hydraulic problems (4th ed.): New York, McGraw-Hill, 274 p. [revised by E.F. Brater.]

Laenen, Antonius, and Orzol, L.L., 1987, Flood hazards along the Toutle and Cowlitz Rivers, Washington, from a hypothetical failure of Castle Lake blockage: U.S. Geological Survey Water-Resources Investigations Report 87-4055, 29 p.

Laenen, Antonius, Scott, K.M., Costa, J.E., and Orzol, L.L., 1987, Hydrologic hazards along Squaw Creek from a hypothetical failure of the glacial moraine impounding Carver Lake near Sisters, Oregon: U.S. Geological Survey Open-File Report 87-41, 48 p.

O'Shea, B.E., 1954, Ruapehu and the Tangiwai Disaster: New Zealand Journal of Science and Technology, sec. B, v. 36, no. 2, p. 174-189.

Osterkamp, W.R., Hupp, C.R., and Blodgett, J.C., 1986, Magnitude and frequency of debris flows, and areas of hazard on Mount Shasta, northern California: U.S. Geological Survey Professional Paper 1396-C, 21 p.

Pearson, M.L., 1986, Sediment yields from the debris avalanche for water years 1980-1983, in Keller, S.A.C., ed., Mount St. Helens—Five years later: Cheney, Eastern Washington University Press, p. 87-107.

Pierson, T.C., 1980, Erosion and deposition by debris flows at Mt. Thomas, North Canterbury, New Zealand: Earth Surface Processes, v. 5, no. 3, p. 227-247.

Pierson, T.C., 1985, Initiation and flow behavior of the 1980 Pine Creek and Muddy River lahars, Mount St. Helens, Washington: Geological Society of America Bulletin, v. 96, no. 4, p. 1056-1069. 
Pierson, T.C., 1986, Flow behavior of channelized debris flows, Mount St. Helens, Washington, in Abrahams, A.D., ed., Hillslope processes: Boston, Allen and Unwin, p. 269-296. [Binghamton Symposia in Geomorphology_-International Series, v. I6.]

Pierson, T.C., and Costa, J.E., I987, A rheologic classification of subaerial sediment-water flows, in Costa, J.E., and Wieczorek, G.F., eds., Debris flows/avalanches; process, recognition, and mitigation: Geological Society of America, Reviews in Engineering Geology, v. 7, p. 1-12.

Pierson, T.C., and Janda, R.J., 1994, Volcanic mixed avalanches-a distinct eruption-triggered mass-flow process at snow-clad volcanoes: Geological Society of America Bulletin, v. 106, no. I0, p. 135I-1358.

Pierson, T.C., Janda, R.J., Thouret, J.-C., and Borrero, C.A., 1990 , Perturbation and melting of snow and ice by the 13 November 1985 eruption of Nevado del Ruiz, Colombia, and consequent mobilization, flow, and deposition of lahars: Journal of Volcanology and Geothermal Research, v. 41, p. 17-66.

Pierson, T.C., and Scott, K.M., I 985, Downstream dilution of a lahar; transition from debris flow to hyperconcentrated streamflow: Water Resources Research, v. 21, no. I0, p. I51 I-I524.

Price, J.T., Lowe, G.W., and Garrison, J.M., I977, Unsteady flow modeling of dam-break waves, in Proceedings of dambreak flood routing model workshop, Bethesda, MD, 1977: Washington, D.C., U.S. Water Resources Council, Hydrology Committee, p. 89-130. [available from National Technical Information Service, Springfield, VA 22161 as NTIS Report PB-275-437.]

Richardson, Donald, 1968, Glacier outburst floods in the Pacific Northwest, in Geological Survey research I968: U.S. Geological Survey Professional Paper 600-D, p. D79-D86.
Smith, G.A., and Lowe, D.R., 1991, Lahars-Volcanohydrologic events and deposition in the debris flowhyperconcentrated flow continuum, in Fisher, R.V., and Smith, G.A., eds., Sedimentation in volcanic settings: SEPM (Society for Sedimentary Geology) Special Publication 45, p. 59-70.

Swift, C.H., III, and Kresch, D.L., 1983, Mudflow hazards along the Toutle and Cowlitz Rivers from a hypothetical failure of Spirit Lake blockage: U.S. Geological Survey Water-Resources Investigations Report 82-4125, I0 p.

Voight, Barry, Janda, R.J., Glicken, Harry, and Douglass, P.M., 1983, Nature and mechanics of the Mount St. Helens rockslide-avalanche, 18 May 1980: Geotechnique, v. 33, no. 3, p. 243-273.

Waitt, R.B., and MacLeod, N.S., I987, Minor explosive eruptions at Mount St. Helens dramatically interacting with winter snowpack in March-April 1982, in Schuster, J.E., ed., Selected papers on the geology of Washington: Washington Department of Natural Resources, Division of Geology and Earth Resources Bulletin 77, p. 355-379.

Waitt, R.B., Jr., Pierson, T.C., MacLeod, N.S., Janda, R.J., Voight, Barry, and Holcomb, R.T., 1983, Eruptiontriggered avalanche, flood, and lahar at Mount St. HelensEffects of winter snowpack: Science, v. 22I, no. 4618, p. I394-I397.

Walder, J.S., and Driedger, C.L., 1994, Geomorphic change caused by outburst floods and debris flows at Mount Rainier, Washington, with emphasis on Tahoma Creek valley: U.S. Geological Survey Open-File Report 93-4093, $93 \mathrm{p}$.

Yesenov, U.Ye., and Degovets, A.S., 1979, Catastrophic mudflow on the Bol'shaya Almatinka River in 1977: Soviet Hydrology-Selected Papers, v. I8, no. 2, p. I58-I60. 


\title{
SEDIMENT TRANSPORT IN THE HYPER- CONCENTRATED PHASE OF THE MARCH 19, 1982, LAHAR
}

\author{
By Randal L. DineharT ${ }^{1}$
}

\section{CONTENTS}

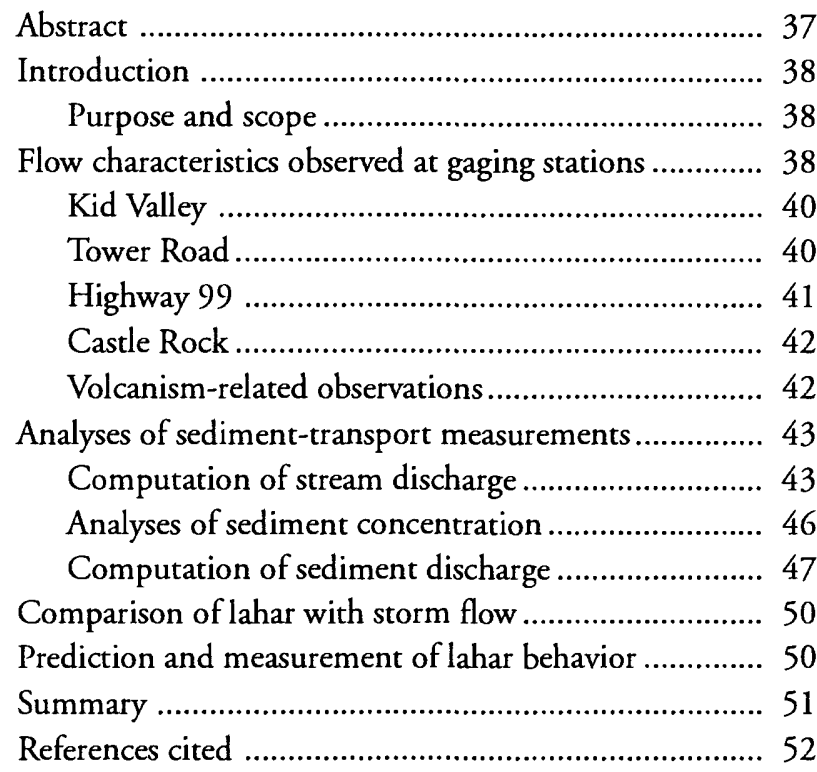

\begin{abstract}
Hyperconcentrated lahars occur rarely, and are even more rarely observed. Synoptic measurements of an eruptiontriggered lahar from Mount St. Helens were made on March 19-20, 1982, at three gaging stations encompassing 37 kilometers on the Toutle River. Measurements were made of surface velocity, stream depths and widths, stream discharge, stream temperature, and river stage; flow samples (depth integrated or dipped) were collected periodically. Decreasing
\end{abstract}

\footnotetext{
${ }^{1}$ Current address: U.S. Geological Survey, Water Resources Division, Placer Hall, 6000 “J" Street, Suite 2012, Sacramento, CA 95819
}

amounts of sediment, from 4.9 to 3.1 million megagrams, were transported past the three gaging stations, and 1.8 million megagrams of sediment were deposited in the Toutle River between the gaging stations at Kid Valley and Highway 99.

Much of the sediment transport occurred at hyperconcentrated levels ( 40 to 80 percent sediment by weight) during passage of the lahar, and the flow characteristics were different from commonly observed sediment transport in several respects. An extraordinary amount of sand was transported at stream discharges typical of storm flow. The high-density flow supported large quantities of woody debris and hot, pumiceous dacite clasts. Rapid deposition of sand, dramatic transitions in flow regimes, and dampened flow turbulence were described in eyewitness accounts at each gaging station.

Rapid fluctuations in channel cross-section geometry and in flow composition were measured as the lahar passed the gaging stations. Peak stream discharge decreased by more than 50 percent between Kid Valley and Highway 99. The peak sediment concentrations also decreased from an estimated $1,600,000$ milligrams per liter at Kid Valley to 980,000 milligrams per liter at Highway 99. The fine-material concentration persisted in the range 250,000 to 350,000 milligrams per liter for three hours, which enabled the watersediment mixture to transport unusually large sediment loads. Computations of sediment discharge for sand and fine-material size classes showed that sand discharges decreased in a downstream direction; however, fine-material discharges were similar at three Toutle River gaging stations. These trends confirmed the observed magnitude of sand deposition along the channel and accounted for the paucity of fine material in the lahar deposits. 


\section{INTRODUCTION}

On the evening of March 19, 1982, the explosive phase of a dome-building eruption at Mount St. Helens generated a snowmelt water flood that transformed to a lahar and entered the North Fork Toutle River as a debris flow (Waitt and others, 1983; Pierson and Scott, 1985; Pierson, chap. 2, this volume). The debris flow phase of the lahar evolved into a hyperconcentrated flow (40-80 percent sediment by weight; $530,000-1,590,000 \mathrm{mg} / \mathrm{L}$, Beverage and Culbertson, 1964). The front of the lahar transformed from debris flow to hyperconcentrated flow along a channel reach 27 to $43 \mathrm{~km}$ from the crater and source area (Pierson and Scott, 1985). The debris flow had transformed before reaching the U.S. Geological Survey (USGS) gaging station on the North Fork Toutle River at Kid Valley and traveled about $50 \mathrm{~km}$ downstream from the gage before dilution below hyperconcentration. Hyperconcentrated phases of lahars were termed "laharrunout flow" by Pierson and Scott (1985) and Scott (1988). The term lahar has been assigned broader meaning than it had previously, which now includes the debris-flow and the hyperconcentrated phases (Smith and Lowe, 1991).

Stream-gaging stations were established along the Toutle River following the mudflow-producing eruption of Mount St. Helens on May 18, 1980, in order to monitor sediment discharge from the rapidly eroding debris avalanche near the crater. Sediment-laden storm flows were measured often for stream and sediment discharge by USGS crews at the stream gaging stations during the two years prior to March 19, 1982. Equipment and techniques were well developed, and channel geometry and flood behavior had been recorded often before the measurements of the hyperconcentrated flow.

This chapter documents the lahar observations and the analyses of hydraulic and sediment transport measurements of the lahar as it passed three gaging stations in the Toutle River. The farthest-upstream stage hydrograph of the lahar was recorded on the North Fork Toutle River at Kid Valley. Stage hydrographs of the lahar were also recorded at two gaging stations on the main stem of the Toutle River. The flow remained in the hyperconcentrated range for several hours throughout the Toutle River system. The flow was finally diluted below the hyperconcentrated range by rapid sedimentation and by mixing with streamflow of the Cowlitz River. The diluted flow was measured and sampled at a fourth gaging station located on the Cowlitz River at Castle Rock.

\section{PURPOSE AND SCOPE}

Before March 19, 1982, the flow behavior of the hyperconcentrated phase of a lahar had never been observed and measured in detail in a natural stream. In fact, hyperconcentrated flows of any kind were poorly recognized in the geologic record or in field observations. Therefore, the purpose of this description of sediment transport in the hyperconcentrated phase of the March 19, 1982, lahar is to present quantitative evidence for flow behavior based mainly on interpretation of field observations. Sediment samples of the flow, collected over time, show variations in the concentration and size distribution of sediment that may prove to be diagnostic of hyperconcentrated flows in general. Measurements of the flow passage along the Toutle River show both the high velocity of the flow and the rapid decrease in stream discharge; such flow behavior had previously been speculative or unknown. Fluid-dynamical analyses or inferences from sedimentary deposits can be found in other references (Laenen and Hansen, 1988; Scott, 1988).

\section{FLOW CHARACTERISTICS OBSERVED AT GAGING STATIONS}

Direct observations, measurements, and continuous river-stage records of the March 19, 1982 lahar were obtained at gaging stations located 49,77,86, and $92 \mathrm{~km}$ downstream from the crater (fig. 3.1). In downstream order, the gaging station names are referred to in the text as follows:

North Fork Toutle River at

Kid Valley :

Kid Valley

Toutle River at Tower Road near

Silver Lake:

Tower Road

Toutle River at Highway 99 near

Castle Rock:

Highway 99

Cowlitz River at Castle Rock:

Castle Rock

The lahar of March 19, 1982, entered the lower North Fork Toutle River when base flow was about $25 \mathrm{~m}^{3} / \mathrm{s}$. At a distance $42 \mathrm{~km}$ downstream from the mountain, the tributary Green River added about $17 \mathrm{~m}^{3} / \mathrm{s}$ to the passing flow. At a downstream distance of $61 \mathrm{~km}(17 \mathrm{~km}$ upstream from Tower Road), the South Fork Toutle River added another $15 \mathrm{~m}^{3} / \mathrm{s}$. At a downstream distance of $88 \mathrm{~km}$ (1.6 km downstream from Highway 99) the lahar 
entered the Cowlitz River where base flow was $357 \mathrm{~m}^{3} / \mathrm{s}$.

Channel conditions of the Toutle River immediately prior to the arrival of the lahar of March 19, 1982 were determined from gaging-station records. Alluvial sand $\left(D_{50}=0.5 \mathrm{~mm}\right)$ had accumulated to depths of about $1 \mathrm{~m}$ near the mouth of the Toutle River following a storm flow on February 20, 1982. Stream discharge had receded steadily after the storm, and shifting channel geometry had been measured weekly at the gaging stations. The records of channel geometry were used to estimate peak discharge of the lahar.

During March 1982, geologic and hydrologic personnel of the USGS had been monitoring the seismic activity at Mount St. Helens continuously. Immediately following the explosive eruption at 1927 Pacific Standard Time (PST) on March 19, 1982, a temperature sensor at the crater floor indicated a rise of several degrees. Concern for the possibility of snowmelt prompted the mobilization of several flood crews. Field personnel arrived at the upstream-most gaging station (Kid Valley) after the lahar peak discharge began to recede. Observations at the other gaging stations were made during most or all of the passage of the lahar. The lahar briefly filled the channel to bankfull level with the muddy, debris-laden sediment load. The chief visual characteristics of the lahar common among the three gaging stations on the Toutle River include:

1. An oily, brown-gray appearance with a smooth, reflective surface where the lahar was not modified by turbulence associated with antidune activity.

2. Floating woody debris ranging from small litter to cut logs and tree stumps with large root balls.

3. Extensive, rapid deposition of sand and gravel in lateral berms immediately after the peak discharge.

4. A progressive transition from a plane surface to standing waves to upstream-migrating antidune waves during the lahar recession.

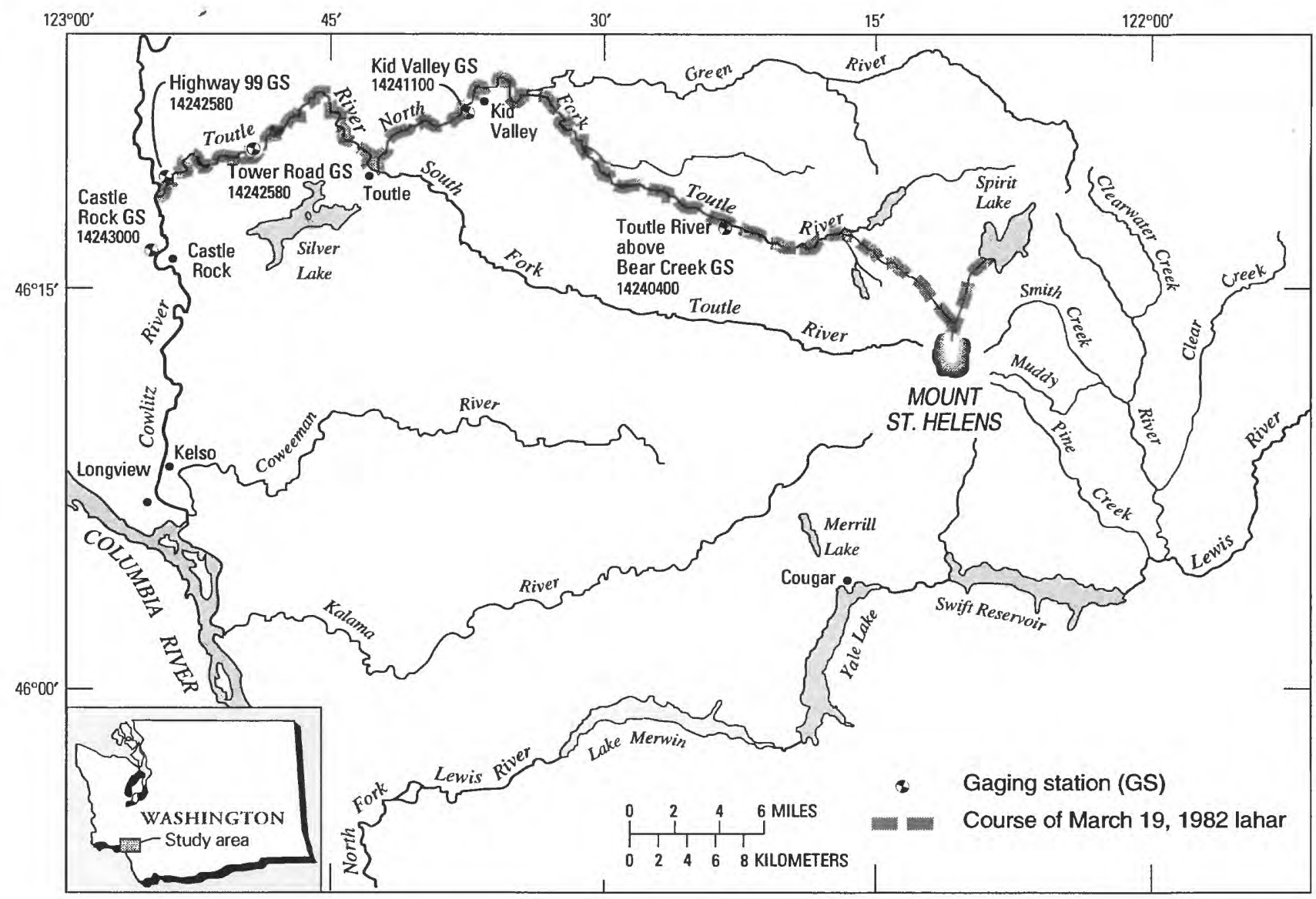

Figure 3.1.-Course of the March 19, 1982, lahar past gaging stations on the Toutle River and Cowlitz River. 
5. Relatively little deposition of woody debris along the Toutle River stream banks compared with the amount of debris transported past the gaging stations.

Hydraulic and sediment-transport measurements of the hyperconcentrated and diluted lahar were made synoptically at the four gaging stations during the flow. At all sites, measurements were made of surface velocity, stream depths and widths, stream discharge, stream temperature, and river stage; flow samples (depth integrated or dipped) were collected periodically. These measurements have been interpreted by researchers to describe the transition in modes of sediment transport (Dinehart, 1983; Pierson and Scott, 1985; Scott and Dinehart, 1985; Scott, 1988). Sediment-concentration data for the lahar are reported in Dinehart (1986).

At all sites, the rise in river stage was rapid and peak stage was attained in less than 30 minutes. During peak discharge, much of the stream surface was obscured by floating logs, tree stumps, and pumiceous dacite clasts of all sizes. The rapid rise and the hazards associated with the floating debris allowed only intermittent measurements of depth, indirect estimates of velocity, and sporadic sediment sampling during the interval of peak discharge.

\section{KID VALLEY}

Initial observations of the lahar were made at the Kid Valley gaging station $49 \mathrm{~km}$ downstream from the crater (fig. 3.1), beginning at 2315 PST on March 19, 1982, 1.3 hours after the arrival of the lahar front. The lahar was in recession from a peak stream discharge estimated at $963 \mathrm{~m}^{3} / \mathrm{s}$, the highest peak discharge at this gaging station since the great May 18, 1980, lahar. (For lahars, the stream discharge is the combined flow-rate of water and sediment past a point on the river.) Lateral berms of massive, poorly sorted medium to coarse sand [described by Scott (1988)] were deposited at streambanks before the arrival of field personnel. Dip samples (Guy and Norman, 1970) of the receding flow were collected immediately by field personnel. Technicians who placed their hands in the flowing lahar felt walnut-sized particles suspended throughout the vertical column and felt the streambed in motion (W.W. Larson and K.K. Lee, USGS, written commun., 1982). Larger clasts (as much as $0.5-\mathrm{m}$ diameter) were transported and deposited through the reach. These clasts were primarily dacite pumice, angular to subrounded, that had varying degrees of porosity. Some clasts were completely suspended in the flowing lahar near midchannel, while clasts near the bank would settle in the shallow depth and tumble intermittently until stopping. Sand continued to accumulate around the deposited pumice clasts as the lahar discharge receded. As described above, sediment samples were collected first by dip sampling, followed by standard sampling with a USD-49 sampler and standard discharge measurements.

\section{TOWER ROAD}

Field personnel at the Tower Road gaging station, $77 \mathrm{~km}$ downstream from the crater, were informed by radio that the approaching lahar was a slurry of mud, and they prepared to observe and sample the lahar. Three observers stood at the right streambank, while the fourth collected sediment samples and measured depth and velocity from a cablecar suspended over the stream. The first pieces of woody debris passed the Tower Road gaging station at 2349 PST on March 19, 1982. The flow reached peak stage in 19 minutes, at 0008 PST on March 20 , and then stream discharge began gradually to recede. Sediment samples were first collected by taping pint bottles to the hanger bar above the USD-74 suspendedsediment sampler and lowering the bottle through the flow. As concentrations decreased, depth-integrated samples were collected with bottles inside the sampler.

Although small fluctuations of stage were recorded at the time of peak flow, no evidence of a secondary pulse in the lahar was apparent. After the peak stage, an increasing percentage of sediment in the lahar rapidly changed the appearance of the stream surface as deposition rates accelerated. The arrival and passage of the lahar was described in detail for the Tower Road gaging station by the author and another field person (unpublished data; S.A. Gustafson, USGS, written commun., 1982) and those observations were summarized by Pierson and Scott (1985) and Scott (1988). A part of the summary by Pierson and Scott (1985, p. 1520-1521) follows:

“...river stage began to rise steadily with little visible change in water turbidity. Within 3 $\mathrm{min}$, the surface of the river was covered with logs and woody debris, but the water was still not muddy. The only significant noise 
from the flow was from debris striking the banks. Seven minutes later discharge was $275 \mathrm{~m}^{3} / \mathrm{s}$, and the flow was noticeably muddier; suspended sediment concentration was measured at $60,000 \mathrm{mg} / \mathrm{L}$, and water temperature had risen to $7.2^{\circ} \mathrm{C}$.

Peak discharge (about $650 \mathrm{~m}^{3} / \mathrm{s}$ ) occurred only $19 \mathrm{~min}$ after the arrival of the flood wave..."

Suspended sediment concentration at 0014 was $158,000 \mathrm{mg} / \mathrm{L}$, and at about this time downstream pointing V-shaped standing waves began to develop. Wave crests were originally about $0.3 \mathrm{~m}$ high, and distance between crests was about $6 \mathrm{~m}$. Between 0020 and 0030 hours the $V$-shaped waves extended all the way across the channel and grew to as high as $2.5 \mathrm{~m}$. At this time the surface of the flow was thickly covered with pumice lapilli and blocks, and deposition of sand-size material was occurring on the river banks; suspendedsediment concentration was about $500,000 \mathrm{mg} / \mathrm{L}$.

About 10 minutes after deposition on the banks began, the large oblique standing waves started breaking vigorously in the upstream direction. Observers noted that they looked like breaking antidunes, only not oriented transverse to the flow. This turbulence roughly corresponded with the time of peak sediment concentration $(1,160,000 \mathrm{mg} / \mathrm{L} ; 67$ percent solids by weight, 43 percent by volume) and it was accompanied by a constant very loud roar, similar to a jet engine. Also, at this time the sound of boulders moving as bed load below the surface could be distinguished. While the antidune activity was vigorous, the flow surface had a smooth, oily appearance. Throughout the recession the flow surface carried pumice and fine woody debris while antidunes continued to form and disappear. Deposition of sand continued. Unlike the upstream debris-flow deposits that remained fluid for days after deposition, these hyperconcentrated-flow deposits drained immediately after deposition and within seconds were firm enough to walk on.

The standing waves of the flow appeared V-shaped in plan view, possibly because of the pronounced lateral velocity gradient in the cross section. Refraction of the waves near the stream banks appeared to accentuate the V-shape. The lateral velocity gradient caused debris in the center of the channel to travel faster than debris floating near the banks. After berm deposition had begun and the lahar discharge had waned noticeably, two of the Tower Road observers drove to the gaging station at Highway 99 to begin measurements at that site.

\section{HIGHWAY 99}

The arrival and peak flow of the lahar was not directly observed at the Highway 99 gaging station, which is $86 \mathrm{~km}$ downstream from the crater. An abrupt increase in river stage was recorded on the continuous chart trace at 0030 PST on March 20, 1982. Observers arrived at about 0130 PST and immediately collected sediment samples using a US D-49 depth-integrating sediment sampler that had a $0.64-\mathrm{cm}$ inlet nozzle. Analyses of sediment data indicated that sampling began about the time of peak sediment concentration. Time between samples ranged from 5 to 15 minutes, because sampling attempts were often delayed by the presence of samplerthreatening woody debris.

Extensive standing waves occurred during the lahar recession at Highway 99, which was similar to the transition of flow regimes observed at Tower Road. Between 10 and 20 standing waves were counted along the approach to the Highway 99 bridge (fig. 3.2). The train of waves would cyclically break upstream, then the stream surface would become nearly plane, and then it would begin to undulate and form standing waves again. Absence of light-colored froth, small eddies, and water bubbles associated with storm flow was taken as evidence of reduced flow turbulence.

A visible contrast of the hyperconcentrated flow with typical storm flows was evidenced by the greater ease of sampling on March 20,1982. The $28.2-\mathrm{kg}$ sediment sampler, which was suspended by cable from a stationary point on the bridge, remained steady in the hyperconcentrated flow. During a typical storm flow of similar depth, immersion of the sampler in the highvelocity flow would cause the sampler to swing erratically. Steadiness of the sampler in the hyperconcentrated flow because of limited flow separation along the sampler body would be consistent with the observations of reduced flow turbulence.

Bank deposition occurred at the outside of the channel bend approaching the bridge. The deposition formed a shallow beach at the right side of the bridge opening, and it eventually extended about $30 \mathrm{~m}$ from the original bank (fig. 3.3). Surface waves broke obliquely across the newly deposited banks, propagating short-crested waves in an upstream direction, which resembled undular bores common to shore flow on sandy ocean beaches. Wave action decreased as the receding flow began to incise the 
newly deposited banks. Patches of mottled, tan color and some surface relief marked locations where the fluid mixture of water and fine sediments was escaping from the sandy bank deposits (fig. 3.4). The new banks repeatedly collapsed, which eroded the beach at the right, outside of the bend. The sediment deposited on the bed at the Highway 99 cross section was removed only after several months of common streamflow, during which the channel thalweg returned to the right from the left side of the bridge opening.

\section{CASTLE ROCK}

At the gaging station at Castle Rock, $92 \mathrm{~km}$ downstream from the crater, the hyperconcentrated lahar from the Toutle River was substantially diluted by the clear stream discharge of the Cowlitz River. Nonetheless, the peak sediment concentration $(157,000 \mathrm{mg} / \mathrm{L})$ was three times higher than the highest sediment concentration measured previously during storm flow at that gaging station $(47,200 \mathrm{mg} / \mathrm{L})$. The logs and woody debris arrived at the Castle Rock bridge at 0115 PST on March 20, 1982, hampering measuring procedures for about 30 minutes (W.P. Johnson, USGS, written commun., 1982). The water surface displayed sediment boils throughout the passage of the flood wave, and the streambed elevation fluctuated about $1 \mathrm{~m}$ because of migrating sand dunes.

\section{VOLCANISM-RELATED OBSERVATIONS}

Dacite clasts in the lahar were hot to the touch at Kid Valley, at the Toutle River below the confluence with the South Fork Toutle River (M.A. Uhrich, USGS, written commun., 1982) and at Tower Road. Several dacite clasts removed from the flowing lahar were too hot to hold bare-handed, and one retrieved clast melted the plastic coating on a glove. The air temperature at Kid Valley

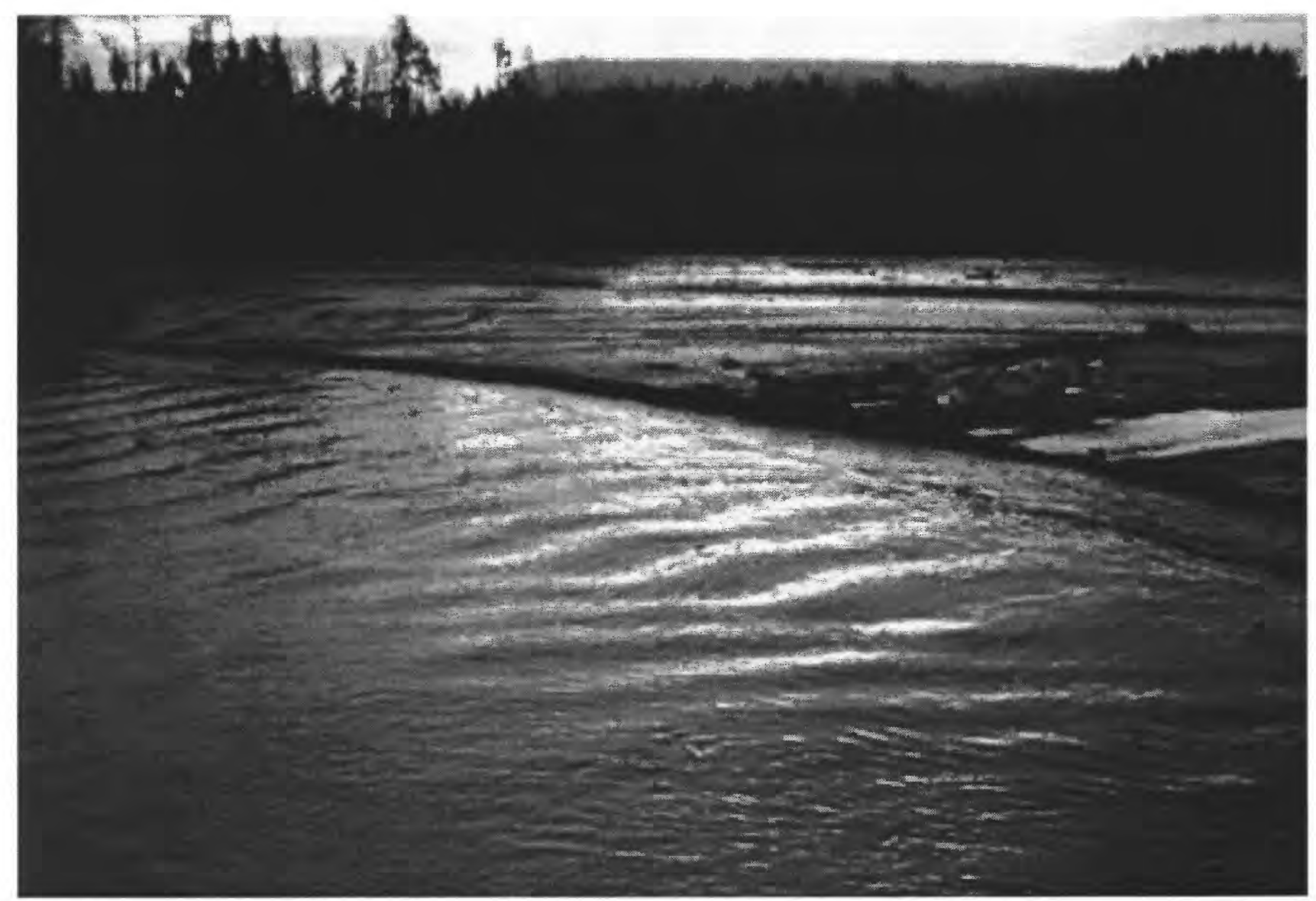

Figure 3.2.-Standing waves in the Toutle River upstream from the Highway 99 bridge. Picture taken during waning of the hyperconcentrated phase of the lahar. Flow is from left to right in foreground. 
was $5.5^{\circ} \mathrm{C}$ at 0500 PST. The cool air temperatures allowed steam to form around the hot clasts and to rise briefly from the lahar surface.

A water sample was collected at Tower Road about 1.5 hours before lahar arrival, and water temperature was $6.5^{\circ} \mathrm{C}$. Flow temperature increased to $10.5^{\circ} \mathrm{C}$ about 2 hours after lahar arrival. At Kid Valley, the first measured temperature of the lahar was $16.5^{\circ} \mathrm{C}$ at midnight, and flow temperature declined to $8.0^{\circ} \mathrm{C}$ by 0700 PST. At Highway 99, flow temperature was probably near $6^{\circ} \mathrm{C}$ before lahar arrival (as at Tower Road), and rose to between $11^{\circ} \mathrm{C}$ and $15^{\circ} \mathrm{C}$ after flow arrival. A strong odor of wet earth was associated with the lahar, but no sulfurous odors were noted. At Kid Valley, airborne ash particles drifted past observation lights like fine snow, and similar fine ash was seen at the town of Toutle by the Tower Road observers.

\section{ANALYSES OF SEDIMENT- TRANSPORT MEASUREMENTS}

Graphs of stream discharge and sediment concentration derived from measurements at gaging stations on the Toutle River are presented in figure 3.5. Downstream attenuation was observed in peak stream discharge, peak sediment concentration, and total sediment discharge. Because calculation of stream and sediment discharge of a lahar is unique in hydrologic analyses, the collection and analysis of the data are discussed in the following three sections.

\section{COMPUTATION OF STREAM DISCHARGE}

Stream discharge was computed for the lahar from a combination of stage readings and intermittent discharge

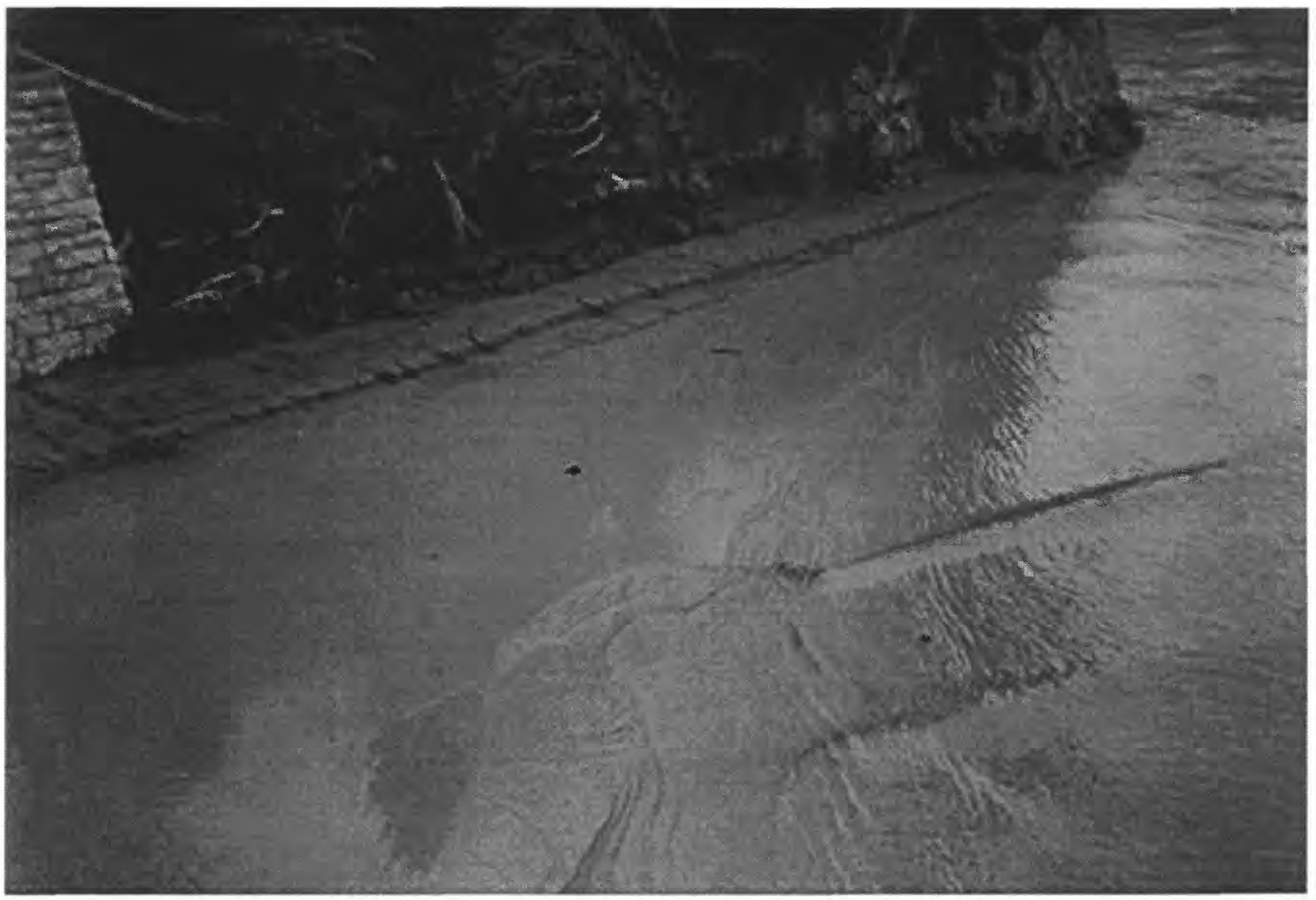

FigURE 3.3.-Newly deposited sand at right side of Toutle River channel, as viewed upstream from the Highway 99 bridge. The shallow flow formed small bores over the wide (30 meters), planar deposits. Main flow is from upper right to lower left. 
estimates and measurements. River stage was measured by periodic wire-weight gage readings and by nitrogen manometers linked to analog and digital continuous recorders. The wire-weight readings are direct measurements of the water-surface elevation relative to a known datum; the river stage recorded by the nitrogen manometer is based on the height of a column of clear water above the sensing orifice in the stream. The manometer readings were exaggerated by the extreme fluid density of the lahar, so the manometer stage records do not correspond directly to changes in the water-surface elevation. Peak sediment concentrations lagged the peak river stage at Tower Road by 34 minutes. The peak stages that were recorded by the manometers at Tower Road and at Highway 99 before the peak sediment concentration are, therefore, close to the true water-

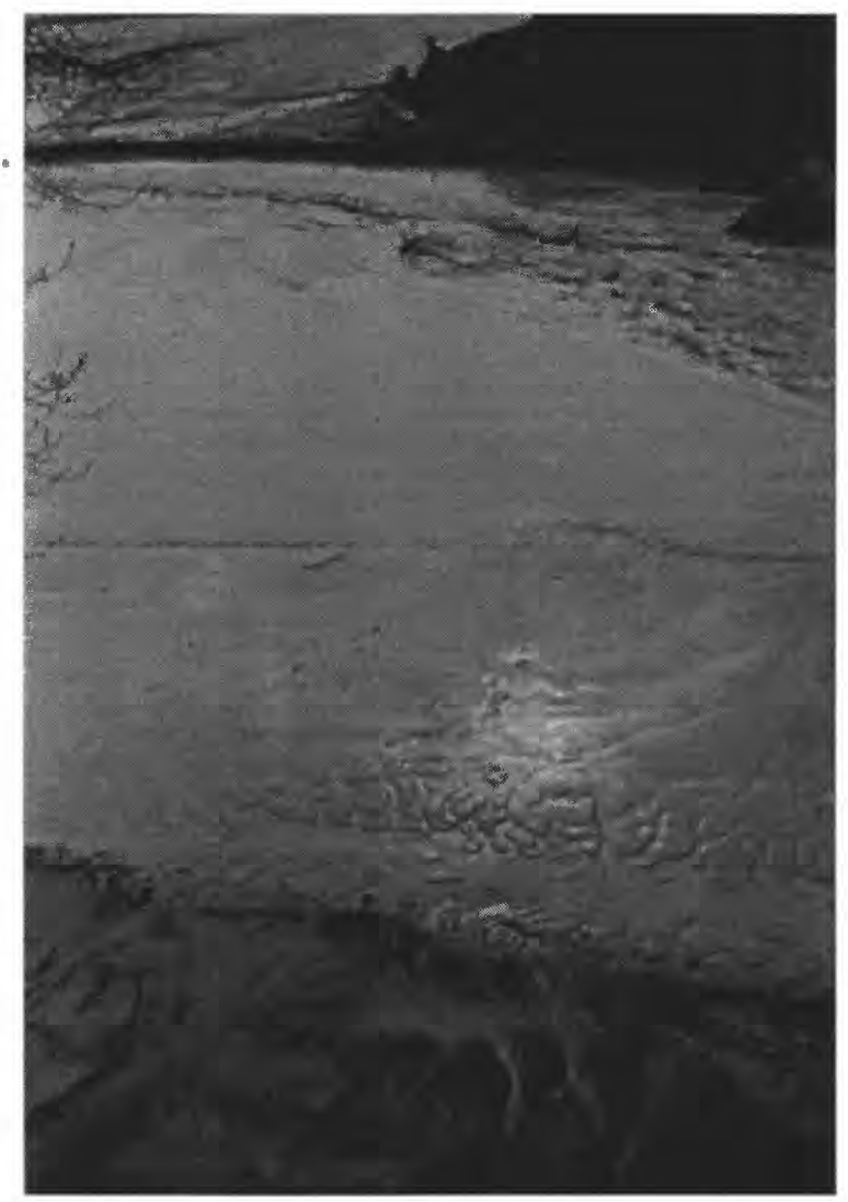

FIGURE 3.4.-Water-sediment mixture of fine material escapes from bank deposits (bottom of photograph) and returns to main flow (top of photograph). View is across upstream side of Highway 99 bridge over Tourle River, taken during waning of lahar. Main flow is from left to right. surface elevations. Subsequent stage records that were obviously affected by increased fluid density were corrected to wire-weight readings.

Standard discharge measurements were attempted during the hyperconcentrated phase of the lahar. Depth measurements were accomplished with sounding weights, but velocity measurements with Price AA current meters were unsuccessful in the sandy, dense lahar. The bucket wheels clogged with sediment and woody debris and rotated very slowly or not at all. As the lahar discharge receded and sediment concentrations decreased, velocity measurements were made with current meters.

Changes in water-surface elevation during the passage of the lahar were due partly to sediment deposition on the streambed. The measured mean bed elevations at the three Toutle River cross sections were raised between 0.5 and $0.7 \mathrm{~m}$ above bed elevations measured before the lahar occurred. Therefore, the stage-discharge relation existing at the arrival of the lahar changed continuously during recession of the lahar when deposition and subsequent incision occurred. The rate at which the stage-discharge relation changed as the lahar discharge receded could not be determined, and interpolative methods were used to compute stream discharge.

The approximate cross-sectional area at the time of peak discharge was computed by extending the area from previous discharge measurements to high-water levels at the cross sections. The streambed geometry was assumed to be stable at the time of peak discharge. This assumption was based on the low sediment concentration sampled at Tower Road at the time of peak discharge. A range of velocities (derived from estimated surface velocities or empirical velocity-area relations) was multiplied by the peak cross-sectional area to obtain peak stream discharge. Where numerous discharge measurements are available for gaging stations with unstable cross sections, the area of the cross section may be related to the mean velocity for the discharge measurement to extrapolate a mean velocity for a greater cross-sectional area. Peak discharge was estimated at Kid Valley by rating curve extension, and at Tower Road and Highway 99 by rating curve extension and velocity-area methods. The peak stream discharges are summarized in table 3.1. (The peak discharge at Castle Rock was greater than the peak discharge at Highway 99 because of the greater base flow in the Cowlitz River.)

To prepare stream-discharge hydrographs, the time and magnitude of peak discharges were plotted, and the discharge recession curve was interpolated between the 


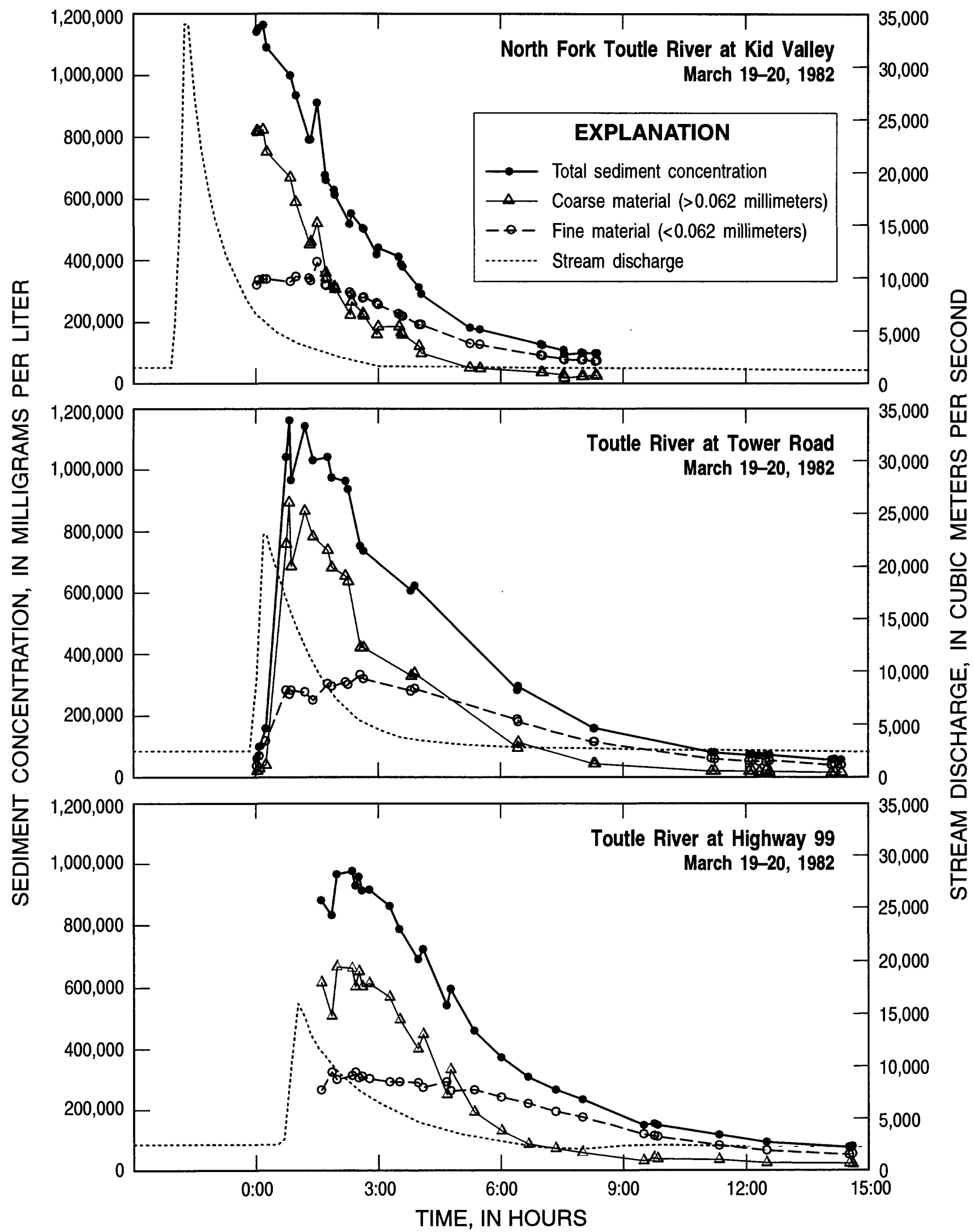

FiguRE 3.5.-Sediment concentration and stream discharge derived from measurements of the hyperconcentrated phase of the lahar at the Toutle River gaging stations. 
TABLE 3.1. - Peak stream discharges at gaging stations along the course of the labar of March 19, 1982

\begin{tabular}{lc}
\hline Location & $\begin{array}{c}\text { Stream discharge } \\
\text { (cubic meters per second) }\end{array}$ \\
\hline North Fork Toutle River at Kid Valley & 963 \\
Toutle River at Tower Road & 651 \\
Toutle River at Highway 99 & 453 \\
Cowlitz River at Castle Rock & 513 \\
\hline
\end{tabular}

peak discharge and subsequent discharge measurements. The time of peak stage (equal to the time of peak discharge) was observed directly only at Tower Road, at 19 minutes after the first arrival of debris and beginning of stage rise. A similar time of 20 minutes for the interval between lahar arrival and peak discharge was assigned to the Kid Valley discharge hydrograph, on the basis of the Tower Road observation. A time interval of 25 minutes was assigned to the Highway 99 discharge hydrograph, which coincided with the first recorded peak on the stage hydrograph for that station.

To interpolate the discharge recession curve for the gaging station records, an initial rapid decrease in discharge was assumed for the first 30 minutes after the peak discharge, based on observations of the lahar at Tower Road. An exponentially decreasing line was drawn from the estimated peak discharge through the discharge measurements made 3 to 6 hours after the peak discharge. The actual rate of recession was uncertain because the streambed rose measurably during recession as the stream discharge of the lahar decreased through sediment deposition.

Sediment deposition from the lahar was the primary cause of downstream attenuation in peak stream discharge. Stream discharge decreased by about onehalf of the peak discharge between Kid Valley and Highway 99. As sediment from the lahar was deposited, the stream discharge decreased. As described under Computation of Sediment Discharge, a large proportion of the stream discharge was sand that decreased rapidly in concentration during channel deposition.

The velocity of the flood wave between the four gaging stations was determined by identifying the time of debris arrival or initial stage rise at each gaging station. Because the extreme lahar density distorted the stage recordings by manometer, the arrival times were the most reliable times available. The arrival times and velocities are summarized in table 3.2. From Kid Valley to Tower Road, the front of the flow traveled $4.4 \mathrm{~m} / \mathrm{s}$, and slowed slightly to $4.1 \mathrm{~m} / \mathrm{s}$ between Tower Road and Highway 99 . The Toutle River enters the larger, slower moving Cowlitz River at 1.6 river $\mathrm{km}$ downstream from Highway 99. The flood wave traveled $2.4 \mathrm{~m} / \mathrm{s}$ between Highway 99 and Castle Rock.

\section{ANALYSES OF SEDIMENT CONCENTRATION}

The highest measured sediment concentrations were about 1 million $\mathrm{mg} / \mathrm{L}$ at the three Toutle River gaging stations; the highest measured sediment concentration at Castle Rock was $157,000 \mathrm{mg} / \mathrm{L}$. Hyperconcentrations are, by definition, greater than 40 percent sediment by weight (Beverage and Culbertson, 1964), which is equivalent to $530,000 \mathrm{mg} / \mathrm{L}$. Therefore, the lahar that passed the Toutle River sites was hyperconcentrated. Sediment samples were collected at the Toutle River gaging stations with standard samplers described by Guy and Norman (1970), except for periods when the sampler nozzles would clog with large sediment particles. At those times, dip samples were collected with open-mouth pint bottles (Guy and Norman, 1970). Some dip sampling was necessary at Kid Valley and Tower Road, but all sediment samples from Highway 99 and Castle Rock were collected with standard samplers. Sediment concentration and particle size were determined according to methods described by Guy (1969).

The peak sediment concentration at the four gaging stations decreased in downstream order. A peak concentration of $1,600,000 \mathrm{mg} / \mathrm{L}$ at Kid Valley was extrapolated from samples collected 70 minutes after the approximate time of the peak concentration. The peak concentrations at Tower Road $(1,170,000 \mathrm{mg} / \mathrm{L})$ and at Highway $99(980,000 \mathrm{mg} / \mathrm{L})$ were interpolated from samples collected about the time of peak concentration.

The peaks in sediment concentration occurred between 25 and 80 minutes after the peak discharges at the Toutle River gaging stations. Sediment concentration 
TABLE 3.2.-Average velocity of flood-wave front along the course of the lahar of March 19, 1982 in the Toutle River, Washington

\begin{tabular}{lccccc}
\hline Location & Time & $\begin{array}{c}\text { Difference } \\
\text { (minutes) }\end{array}$ & $\begin{array}{c}\text { River } \\
\text { kilometer }\end{array}$ & $\begin{array}{c}\text { Difference } \\
\text { (kilometers) }\end{array}$ & $\begin{array}{c}\text { Velocity } \\
(\mathrm{m} / \mathrm{s})\end{array}$ \\
\hline Kid Valley & 2155 & 116 & 38.8 & & 4.4 \\
Tower Road & 2351 & & & 28.3 & 4.1 \\
Highway 99 & 0030 & 39 & 10.5 & 8.9 & 2.9 \\
Castle Rock & 0115 & 45 & 1.6 & & \\
\hline
\end{tabular}

also lagged peak stream discharge during storm flow in the Toutle River during 1981 and 1982. The primary sediment sources were several tens of kilometers from the gaging stations where the concentrations were measured, and the distance between sediment source and measuring point is a major factor in the lagging of peak sediment concentration behind peak discharge (Williams, 1989).

Sediment-concentration graphs for the Toutle River sites (fig. 3.5) show an order of magnitude decrease in concentration within 10 hours of peak concentration. During that period, more than 100 samples were collected at the Toutle River sites. The total sediment concentration and the coarse-material (sizes from $0.062 \mathrm{~mm}$ to $2.0 \mathrm{~mm}$ ) concentration followed similar rise and decay curves. The coarse material reached peak concentrations that were twice the fine material (sizes finer than $0.062 \mathrm{~mm}$ ) and receded in concentration more rapidly. Fine-material concentration persisted in the range 250,000 to $350,000 \mathrm{mg} / \mathrm{L}$ for three hours during the main passage of the lahar.

Particle-size distributions in the coarse-material size range were obtained for all sediment samples collected during the flow. Concentration graphs of individual size classes (fig. 3.6) were fitted well by exponential-decay curves (Dinehart, 1983). The concentration of the coarser sands receded more rapidly, indicating that the hyperconcentrated phase was characterized by differential settling. By contrast, sediment samples of debris flows show that most particle sizes deposit at a uniform rate.

The persistence of fine-material concentration in a range narrower than sand concentration during flow passage was noted by Dinehart (1983). The finite source of sediment in the fine-material size range may have limited the attainment of fine-material concentrations higher than $350,000 \mathrm{mg} / \mathrm{L}$. Because the settling velocity of silts and clays is less than that of sands, it is reasonable to deduce that fine material was transported through the Toutle River with less deposition and thus with less reduction in concentration. The fine material also continued to drain from coarse-material deposits and return to the stream for transport (Scott, 1988).

The sediment-concentration graph for Castle Rock (fig. 3.7) shows that most of the suspended-sediment load transported past this gaging station was fine material. Although much of the sediment load at the upstream gaging stations was sand, the deposition of sand along the Toutle River attenuated suspended-sand discharge at Castle Rock. Sediment discharge of fine material past Highway 99 was about the same as the total suspendedsediment discharge past Castle Rock for March 20, 1982. Substantial sand deposition occurred between the two stations, especially at the mouth of the Toutle, and some sand presumably became unsampled bedload in the Cowlitz River. In the following section, sediment discharges in various size classes are compared to show the amount of sediment deposition between stations.

\section{COMPUTATION OF SEDIMENT DISCHARGE}

Sediment discharge at each gaging station (tables 3.3, 3.4) was computed by subdividing the stream discharge and the concentration graphs into appropriate time intervals. The sediment discharge for each interval was 


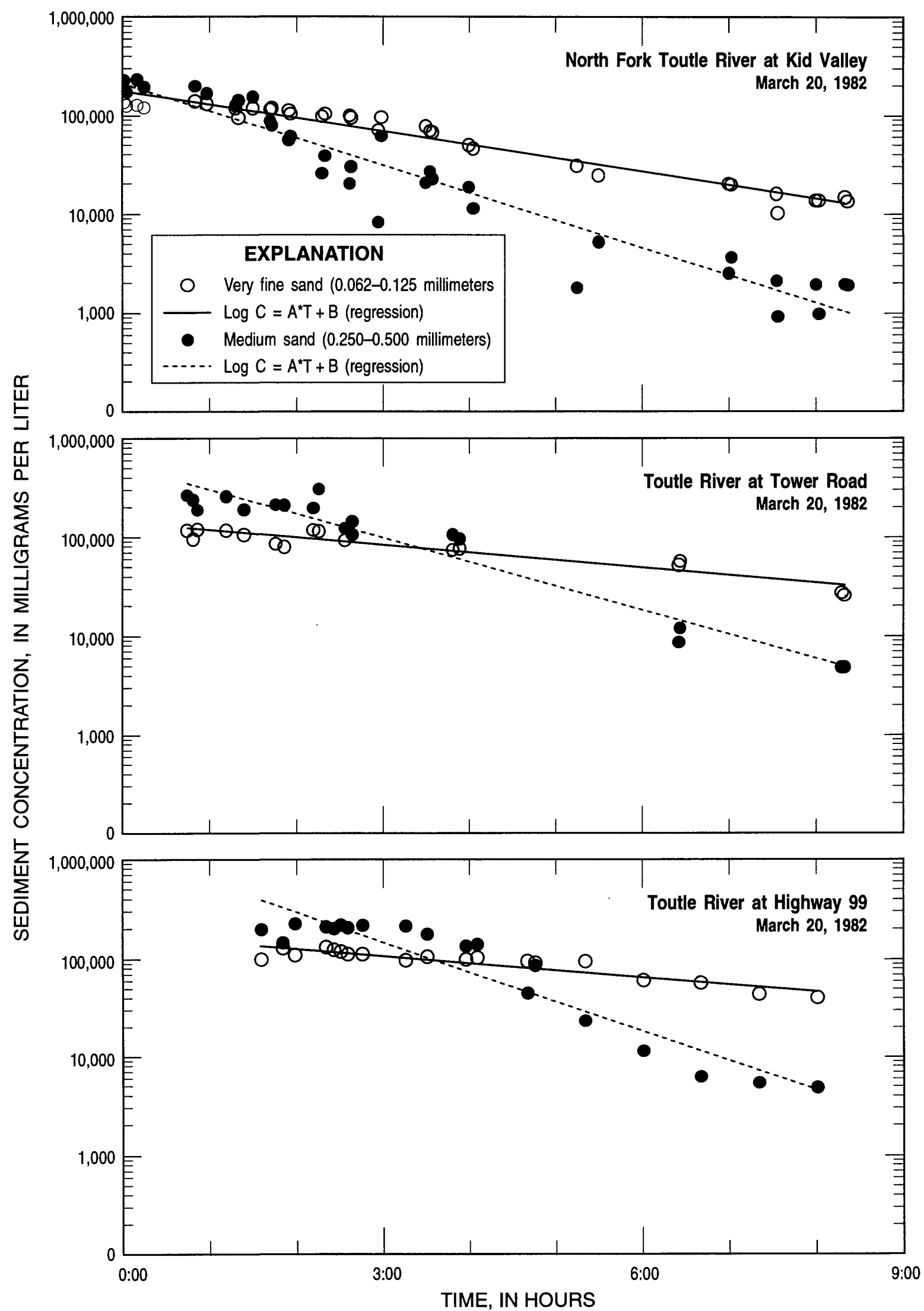

FIGURE 3.6.-Sediment concentration in two sand-size classes for the hyperconcentrated phase of the lahar, fit with an exponential recession curve. 
computed by the equation

$$
Q_{s}=C Q_{(w+s)} a
$$

where $Q_{s}$ is sediment discharge, $C$ is sediment concentration in $\mathrm{mg} / \mathrm{L}, \mathrm{Q}_{(\mathrm{w}+\mathrm{s})}$ is stream discharge of the water-sediment mixture, and $\mathrm{a}$ is a coefficient for units of measurement and time interval. The values for each interval were summed to obtain the suspended-sediment discharge for the day. This procedure was applied to concentration curves of total suspended sediment, sand fraction, fine fraction, and (for Tower Road and Highway 99) sediment-size classes from $0.062 \mathrm{~mm}$ to $1.00 \mathrm{~mm}$. In table 3.3, the total suspended-sediment discharge at Kid Valley for March 19 plus March 20 is compared with the totals at Tower Road and Highway 99 for March 20 only, using data from Dinehart (1986). The sediment discharge at Kid Valley on March 19 before the lahar was 0.2 percent of the 2-day total. During the last hour of March 20,1982, the lahar was in complete recession everywhere, and sediment discharges for that time interval were again less than 1 percent of the total sediment discharge for the flow.

Although only 50 to 70 percent of the sediment sampled in the lahar at Kid Valley was sand size and larger (Dinehart, 1986), the lahar deposits near the site were
95 percent sand size and larger (Scott, 1988). The difference in sediment proportions is due to the passage of much of the fine material through the Toutle River to the Cowlitz River without deposition. Sediment discharge values (table 3.3) show a 46-percent loss in sand discharge between Kid Valley and Highway 99. A 10 -percent loss in fine-material discharge was measured for the same reach.

Sediment discharges for four sand-size classes also were computed from concentration curves based on particle-size analyses of sediment samples from Tower Road and Highway 99 (Dinehart, 1986). Downstream differences in sediment discharge ranged from 2 to 14 percent (table 3.4). The sand loss computed from totals of individual sand-size classes from $0.062 \mathrm{~mm}$ to $1.00 \mathrm{~mm}$ was $201,000 \mathrm{Mg}$, whereas the loss computed from the entire sand fraction was $280,000 \mathrm{Mg}$. Erratic variation in the sand-concentration curves and the additional, uncomputed sediment discharge for size classes greater than $1.00 \mathrm{~mm}$ can account for the disparity. The samples collected during the lahar may not have defined the true trends in sand concentrations, but the downstream differences in sediment discharge of individual sand-size classes all confirm the magnitude of sediment deposition between the two gaging stations.

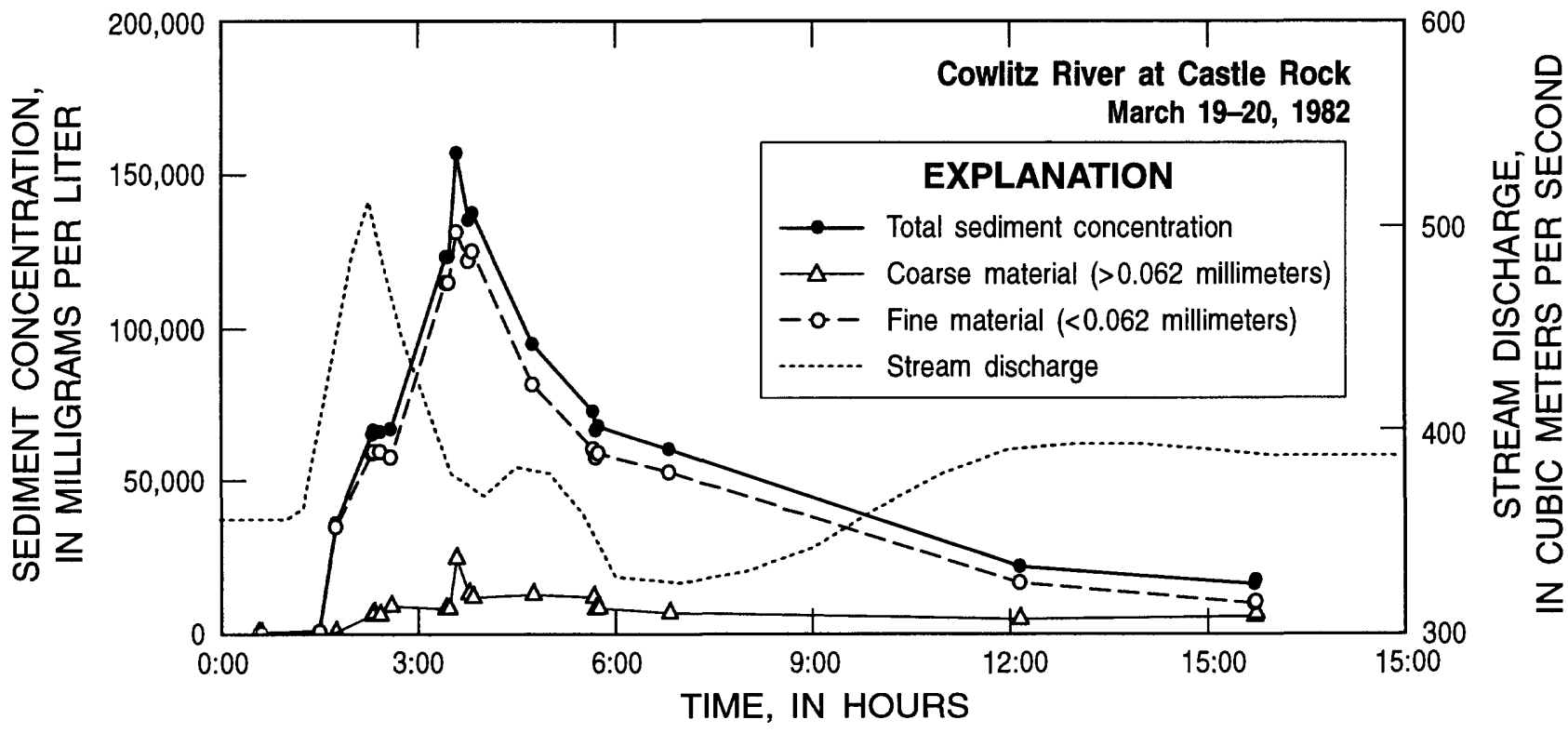

FigURE 3.7.-Sediment concentration of the lahar-generated flood wave measured at the gaging station on the Cowlitz River at Castle Rock. Most of the suspended-sediment load transported past this gaging station was fine material. 
TABLE 3.3.-Sediment discharges of lahar of March 19-20, 1982, in the Toutle River (in megagrams (Mg]). Discharges of fine and sand sediment may not equal total sediment discharge, because all discharges were computed independently from separate concentration curves

\begin{tabular}{lccc}
\hline Location & $\begin{array}{c}\text { Total sediment } \\
\text { discharge }\end{array}$ & $\begin{array}{c}\text { Fine sediment } \\
\text { discharge (less } \\
\text { than 0.062 mm) }\end{array}$ & $\begin{array}{c}\text { Sand sediment } \\
\text { discharge (greater } \\
\text { than 0.062 } \mathrm{mm} \text { ) }\end{array}$ \\
\hline Kid Valley & $4,930,000$ & $1,420,000$ & $3,500,000$ \\
Tower Road & $3,550,000$ & $1,390,000$ & $2,160,000$ \\
Highway 99 & $3,130,000$ & $1,250,000$ & $1,880,000$ \\
$\begin{array}{l}\text { Difference from Kid Valley } \\
\text { to Highway 99 }\end{array}$ & $1,800,000$ & 170,000 & $1,620,000$ \\
\hline
\end{tabular}

TABLE 3.4.-Sediment discharge in sand-size classes at two gaging stations along the course of labar of March 19-20, 1982 in the Toutle River (in megagrams [Mg])

\begin{tabular}{ccccc}
\hline $\begin{array}{c}\text { Size class } \\
(\mathrm{mm})\end{array}$ & Tower Road & Highway 99 & Difference & $\begin{array}{c}\text { Percent } \\
\text { difference }\end{array}$ \\
\hline $0.062-0.125$ & 431,000 & 370,000 & 61,000 & 14 \\
$0.125-0.250$ & 589,000 & 575,000 & 14,000 & 2 \\
$0.250-0.500$ & 624,000 & 543,000 & 81,000 & 13 \\
$0.500-1.00$ & 318,000 & 273,000 & 45,000 & 14 \\
\hline
\end{tabular}

\section{COMPARISON OF LAHAR WITH STORM FLOW}

The hyperconcentrated phase of the March 19, 1982, lahar was highly effective in transporting sediment from Mount St. Helens. A storm flow on February 20, 1982, in the Toutle River basin transported about 2 million more megagrams of sediment past the Highway 99 gaging station than did the March 19, 1982, lahar (table 3.5). Although the sediment discharge was 1.7 times greater than the lahar, the daily mean stream discharge was 7.5 times greater than on March 20. The high concentration of fine material that persisted during the hyperconcentrated phase probably accounted for the greater total sediment discharge. Fine-material concentration in the storm flow probably did not exceed $150,000 \mathrm{mg} / \mathrm{L}$, on the basis of samples collected during the brief period of peak discharge (Dinehart, 1986). In the lahar, fine material at concentrations near 250,000 to $350,000 \mathrm{mg} / \mathrm{L}$ were transported by a smaller volume of streamflow because unreworked deposits were eroded near the crater. Additional fine material was acquired by the lahar as it eroded extensive fine-grained reservoir deposits impounded behind the 1980 sediment-retention structure (fig. 3.1). The resulting dense, yet highly mobile, mixture of water and fine sediments reduced the fall velocities of coarser sediments so that sand concentrations remained far greater than observed at the higher stream discharges of typical sediment-laden storm flows.

\section{PREDICTION AND MEASUREMENT OF LAHAR BEHAVIOR}

The lahar from Mount St. Helens reached the mouth of the Toutle River with unexpected rapidity. Traveling $86 \mathrm{~km}$ in 5 hours, the lahar front moved at an average 
TABLE 3.5.-Comparison of stream discharge and sediment transport on February 20 and March 20, 1982, at Toutle River at Highway 99

\begin{tabular}{cccc}
\hline & $\begin{array}{c}\text { Daily } \\
\text { mean } \\
\text { discharge } \\
\left(\mathrm{m}^{3} / \mathrm{s}\right)\end{array}$ & $\begin{array}{c}\text { Daily } \\
\text { suspended- } \\
\text { sediment } \\
\text { discharge }(\mathrm{Mg})\end{array}$ & $\begin{array}{c}\text { Daily } \\
\text { mean sediment } \\
\text { concentration } \\
(\mathrm{mg} / \mathrm{L})\end{array}$ \\
\hline February 20 & 603 & $5,430,000$ & 81,100 \\
March 20 & 80 & $3,130,000$ & 234,000 \\
\hline
\end{tabular}

velocity of $4.8 \mathrm{~m} / \mathrm{s}$. This is nearly twice the velocity of $2.5 \mathrm{~m} / \mathrm{s}$ that had been estimated for a debris flow originating from a pyroclastic flow on snow at Mount St. Helens (Dunne and Leopold, 1981). Although the kinematic viscosity of a sediment-laden flow increases with increasing silt and clay concentration (Simons and others, 1963), the increased viscosity did not retard flow velocity significantly. The lahar front traveled from Kid Valley to Highway 99 in about the same time as flood waves of several previous storm flows.

Travel times of debris flows in the Toutle River were predicted from digital models (Swift and Kresch, 1983; Laenen and Hansen, 1988). Long travel times for Toutle River debris flows that were computed by Swift and Kresch (1983) appeared to result from overly large assigned values of the consistency index " $\mu$." Laenen and Hansen (1988) modeled the March 19, 1982 lahar and reported that the travel times, among other hydrologic parameters, were sensitive to the values of " $\mu$ " and Manning's " $\mathrm{n}$." Their model indicated that flood waves for storm flows of the same magnitude would take approximately twice as long as the modeled lahars to travel from Kid Valley to Highway 99. However, the hyperconcentrated flood wave traveled at a celerity very near that of five storm-flow flood waves that were measured during 1980 and 1981 (Dinehart, 1982).

Behavior of a flow like the March 19, 1982, lahar is difficult to predict because hyperconcentrated lahars occur rarely and are even more rarely observed. In environments where lahars may be expected and an opportunity for observation is presented, several types of nonstandard measurements are desirable. Constant sampling of the flowing lahar will provide a useful sediment-concentration time series. Measurements of flow depth throughout lahar passage can be used to estimate rates of deposition. Recorded observations of water temperature, flow regime, and bank deposits are also valuable. High-angle video recordings of the flow will provide evidence for estimates of surface velocity and flow regime. For volcaniclastic sediments, laboratory analyses may include clay mineralogy and measurements of the specific gravities of various size classes. These measurements will yield a more accurate description of the dynamic changes in sediment transport that occur during lahar passage.

\section{SUMMARY}

Rapid snowmelt in the crater of Mount St. Helens, caused by a minor volcanic eruption on March 19, 1982, eroded sediment that was transported rapidly down the Toutle River. Immediate deployment of field personnel to three gaging stations along the Toutle River enabled the hyperconcentrated phase of the flowing lahar to be measured in detail. The sediment transport and stream discharge data indicated that sand deposition was extensive along the course of the lahar. Particle-size distributions of sediment samples were used to determine the changes in concentration of various sediment-size classes. Knowledge of the settling behavior was used to interpret the lahar deposits that were examined by Scott (1988). The main results of the study are:

1. Lahars, in their hyperconcentrated phase, are overwhelmingly depositional, yet are capable of transporting large quantities of sediment several tens of kilometers from their source.

2. Standard techniques of discharge measurement are not adequate to define discharge hydrographs for a lahar passing a gaging station. Direct, continuous measurements of cross-section geometry, river stage, and flow velocity can aid in discharge estimation.

3. Fine-material concentration remained constant in a range from 250,000 to $350,000 \mathrm{mg} / \mathrm{L}$, which 
was coincident with the duration of the hyperconcentrated range of the lahar.

4. Coarse-material concentration reached higher levels than fine-material concentration.

5. Differential settling of coarse sediments was evident, and may be characteristic of hyperconcentrated flows in general.

6. The peak stage coincided with peak discharge of the flow, although streambed deposition after peak stage was greater than $0.5 \mathrm{~m}$ at the gaging stations along the Toutle River.

\section{REFERENCES CITED}

Beverage, J.P., and Culbertson, J.K., 1964, Hyperconcentrations of suspended sediment: American Society of Civil Engineers Proceedings, Journal of the Hydraulics Division, v. 90, HY6, p. 117-128.

Dinehart, R.L., 1982, Sediment-discharge characteristics of the Toutle River following the Mount St. Helens eruption [abs.]: Conference on Mount St. Helens-Effects on water resources, Jantzen Beach, Or., 1981, Proceedings, p. 149.

Dinehart, R.L., 1983, Patterns of sediment concentration in hyperconcentrated flows at Mount St. Helens [abs.]: Eos, American Geophysical Union, Transactions, v. 64, no. 45, p. 707.

Dinehart, R.L., 1986, Sediment data for streams near Mount St. Helens, Washington, v. 2- water years 1981-83: U.S. Geological Survey Open-File Report 85-632, 438 p.

Dunne, Thomas, and Leopold, L.B., 1981, Flood and sedimentation hazards in the Toutle and Cowlitz River system as a result of the Mount St. Helens eruption, 1980 - Review and assessment for the Federal Emergency Management Agency (FEMA): Federal Emergency Management Agency, 92 p.

Guy, H.P., 1969, Laboratory theory and methods for sediment analysis: U.S. Geological Survey Techniques of WaterResources Investigations, book 5, chap. C1, 58 p.

Guy, H.P., and Norman, V.W., 1970, Field methods for measurement of fluvial sediment: U.S. Geological Survey Techniques of Water-Resources Investigations, book 3, chap. C2, $59 \mathrm{p}$.
Laenen, Antonius, and Hansen, R.P., 1988, Simulation of three lahars in the Mount St. Helens area, Washington, using a one-dimensional, unsteady-state streamflow model: U.S. Geological Survey Water-Resources Investigations Report 88-4004, $20 \mathrm{p}$.

Pierson, T.C., and Scott, K.M., 1985, Downstream dilution of a lahar: transition from debris flow to hyperconcentrated streamflow: Water Resources Research, v. 21, no. 10, p. 1511-1524.

Scott, K.M., 1988, Origins, behavior, and sedimentology of lahars and lahar-runout flows in the Toutle-Cowlitz River system, Mount St. Helens, Washington: U.S. Geological Survey Professional Paper 1447-A, 74 p.

Scott, K.M., and Dinehart, R.L., 1985, Sediment transport and deposit characteristics of hyperconcentrated streamflow evolved from lahars at Mount St. Helens, Washington: International Workshop on Flow at Hyperconcentrations of Sediment, Beijing, China, 1985, Beijing, China.

Simons, D.R.,Richardson, E.V., and Haushild, W.L., 1963, Some effects of fine sediment on flow phenomena, U.S. Geological Survey Professional Paper 1498-G, 47 p.

Smith, G.A., and Lowe, D.R., 1991, Lahars-Volcanohydrologic events and deposition in the debris flowhyperconcentrated flow continuum, in Fisher, R.V., and Smith, G.A., eds., Sedimentation in volcanic settings: SEPM (Society for Sedimentary Geology) Special Publication 45, p. 59-70.

Swift, C.H., III, and Kresch, D.L., 1983, Mudflow hazards along the Toutle and Cowlitz Rivers from a hypothetical failure of Spirit Lake blockage: U.S. Geological Survey Water-Resources Investigations Report 82-4125, $10 \mathrm{p}$.

Waitt, R.B., Pierson, T.C., MacLeod, N.S., Janda, R.J., Voight, Barry, and Holcomb, R.T., 1983, Eruption-triggered avalanche, flood, and lahar at Mount St. Helens-effects of winter snowpack: Science, v. 221, p. 1394-1397.

Williams, G.P., 1989, Sediment concentration versus water discharge during single hydrologic events in rivers: Journal of Hydrology, v. 111, p. 89-106. 


\title{
$4:$ \\ DOME-COLLAPSE ROCKSLIDE AND MULTIPLE SEDIMENT-WATER FLOWS GENERATED BY A SMALL EXPLOSIVE ERUPTION ON FEBRUARY 2-3, 1983
}

\author{
By Thomas C. Pierson and Richard B. WaitT
}

\section{CONTENTS}

Abstract

The eruption of February 2-3, 1983 53

Eyewitness accounts 55

Eruption seismicity .. 55

Study methods 55

Volcanic processes affecting snowpack ............................ 55

Ballistic shower ........................................................ 57

Rockslide from lava dome ....................................... 57

Ash cloud ................................................................ 57

Tephra fall .............................................................. 57

Flows mobilized by pyroclast-snow interactions ......... 57

Mixed avalanche …………………………………..... 57

Mixed slushflow …………………………………... 62

Water flow and debris flow ...................................... 62

Sequence and timing of flows ............................................ 66

Source and effects of meltwater .....................................66 66

Similarity to events of March 19, 1982 .......................... 67

Mixed avalanche initiation mechanisms ......................... 67

Summary ………………………………………..... 67

References cited ............................................................ 68

\begin{abstract}
There is mounting evidence that significantly hazardous hydrologic consequences can result from small volcanic eruptions when ice and snow are present near the vent. Such was the case at Mount St. Helens during a small, dome-building eruption on February 2-3, 1983. Two explosive eruptive bursts
\end{abstract}

began the eruption in the snow-filled crater, each sending plumes to about 6,100 meters in altitude. The plume from the initial burst, beginning at 2339 Pacific Standard Time on February 2, was dark-colored and was probably accompanied by minor ejection of ballistic fragments. The second burst began at 0256 on February 3 and had a plume that was lighter in color. Within about 5 minutes the second burst successively caused: (1) a ballistic shower that rapidly loaded the east crater wall with hot volcaniclastic debris; (2) a $10^{5}$-cubic-meter avalanche of wet snow and hot rock fragments from the ballistic impact area; and (3) a gravitational collapse of part of the lava dome, resulting in a hot rockslide, $10^{4}$ to $10^{5}$ cubic meters in volume, onto the snow-covered crater floor. For the next onehalf hour, sustained meltwater production at relatively low discharge saturated and remobilized part of the avalanche deposit and then eroded a channel through the avalanche deposit and into the crater floor. Some meltwater flow transformed to a debris flow in a steep, deeply incised northflank channel that drained the crater.

Ballistic impacts of hot pyroclastic debris apparently triggered the initial snow avalanches, although the exact triggering mechanism is not clear. Heat from the rockslide deposit, conducted to the underlying snowpack and possibly supplemented by radiant heating from the incandescent rockslide headwall, produced the sustained meltwater flow that followed. It was the smaller, less energetic of two explosive eruptive bursts that mobilized the sediment-water flows, indicating that the risk of snowmelt-generated flows may be more directly related to the relative effectiveness of hot-rock emplacement on snow slopes than to eruption magnitude. From a hydrologic perspective therefore, a larger eruption is not necessarily more hazardous than a smaller one. 


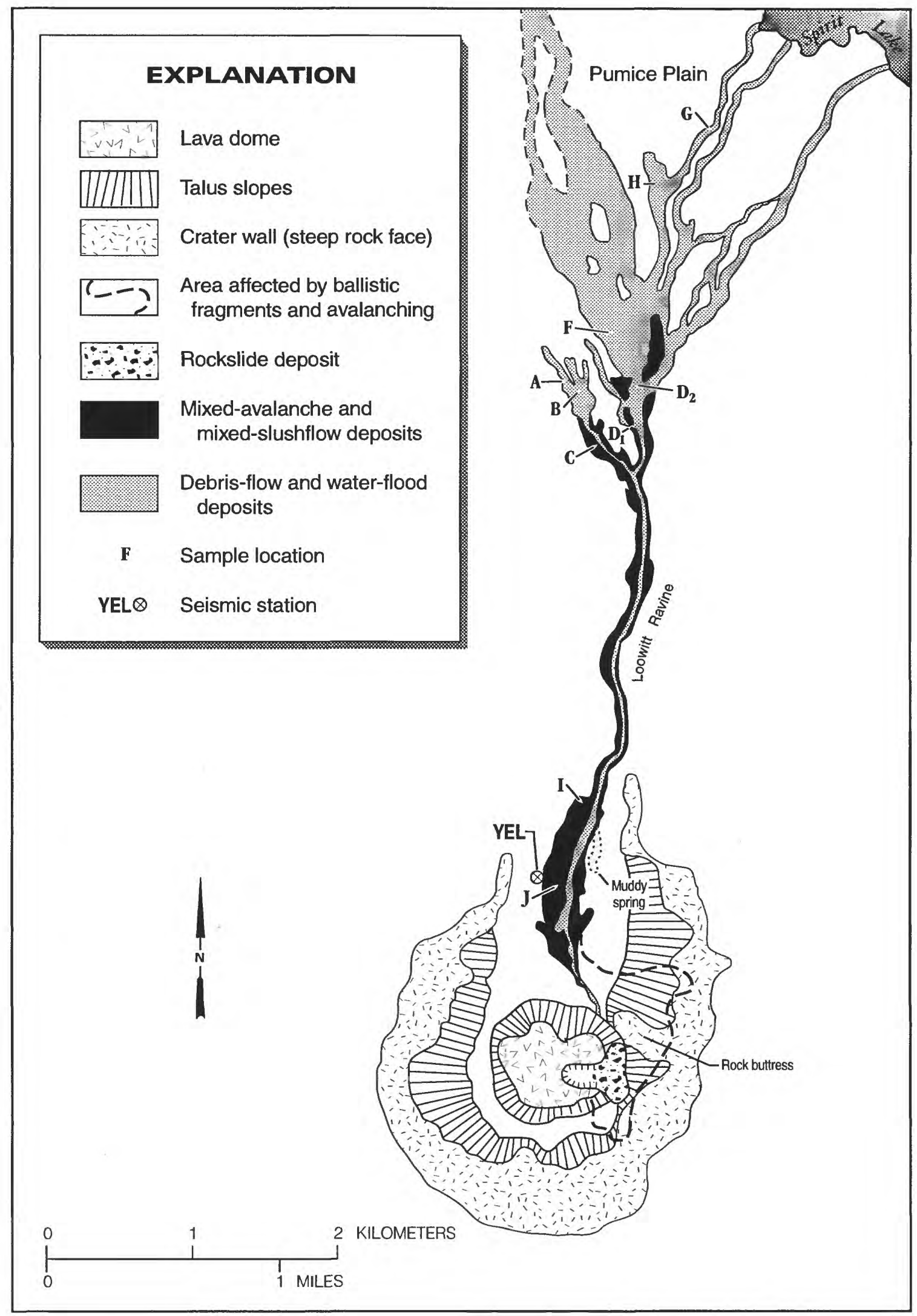

FiguRE 4.1.-Flow paths and deposits of sediment-water flows triggered by an explosive burst at Mount St. Helens on February 3, 1983, during a dome-building eruption. Seismic station YEL is shown; station EDM is located just off the map, 2.5 kilometers east of the lava dome. 


\section{THE ERUPTION OF FEBRUARY 2-3, 1983}

At the onset of a sustained dome-building eruption in early February 1983, a hot rockslide from the lava dome and a sequence of flows consisting of snow grains, volcaniclastic sediment, and water (figs. $4.1,4.2$ ) were triggered by the second of two relatively similar explosive bursts from the side of the dome that were separated by about 3.5 hours. Prior to these events, the steep crater walls were coated by snow and ice, and the crater floor was covered by as much as several meters of snow. A storm on January 27 had added $15 \mathrm{~cm}$ of new snow at Spirit Lake and at least as much in the crater. For five days before the beginning of the eruption, temperatures in the crater stayed slightly below freezing. At a few minutes after midnight on February 3, the air temperature at Spirit Lake (at about $1,040 \mathrm{~m}$ altitude) was $-0.6^{\circ} \mathrm{C}$ (U.S. Army Corps of Engineers, radio log, February 3, 1983). When the standard lapse rate of $0.6^{\circ} \mathrm{C} / 100 \mathrm{~m}$ is applied, air temperature at the level of the crater walls would have been about $-7^{\circ} \mathrm{C}$ to $-9^{\circ} \mathrm{C}$ at the time of the explosive events.

\section{EYEWITNESS ACCOUNTS}

Personnel at the Spirit Lake pumping barge $8 \mathrm{~km}$ from the dome observed some of the events by moonlight (U.S. Army Corps of Engineers, radio log, February 2-3, 1983; Harder Engineering, daily logs, February 2-4, 1983; N.R. Larson, U.S. Army Corps of Engineers [retired], written commun., 1987). At about 2339 Pacific Standard Time on February 2, observers saw a large, dark eruption plume rise and drift to the northwest, obscuring the crater. Visibility improved after about 30 minutes, but nothing else unusual was observed until a second eruption plume, lighter in color than the first, rose at 0256 on February 3. The National Weather Service at Portland Airport detected both plumes at about $6,100 \mathrm{~m}$ altitude. Within about five minutes, the crater cleared again, and a pulsing incandescent glow near the top of the dome indicated to the observers that part of the dome had failed. Shortly thereafter, the view into the crater was obscured by what looked to be steam, and then a dark mass appeared to move out of the crater and down the north flank of the volcano. The next day, field crews confirmed that part of the east sector of the lava dome had collapsed as a rockslide that extended out toward the east crater wall, and a large, dark, mixed- avalanche deposit covered part of the crater floor and extended down onto the Pumice Plain, the pyroclastic debris fan at the foot of the volcano.

\section{ERUPTION SEISMICITY}

Seismometers located about $1,000 \mathrm{~m}$ north (station YEL) and 2,500 m east (station EDM) of the lava dome recorded both eruptive bursts (fig. 4.3). The YEL site was narrowly missed (within meters) by the avalanche (fig. 4.1). For the first eruptive burst, the seismic signal began abruptly, increasing from zero to full scale in 7 seconds. The YEL recorder remained at full scale for 6 minutes; the more distant EDM remained at full scale for only 90 seconds. The YEL and EDM seismic records continued with about 5 and 8 minutes of fluctuating moderate-amplitude signal and then about 50 and 21 minutes of decreasing low-amplitude signal. Gain on the YEL seismograph was set at about one-half that for the EDM seismograph.

The second eruptive burst was shorter in seismic duration and slightly less intense than the initial burst. It began more gradually, taking about 20 seconds to attain full scale, but dropped off much more abruptly. The YEL seismograph was at full scale for about 6 minutes; the EDM instrument was at full scale for about 50 seconds. Decreasing moderate-amplitude signals were recorded for 6 minutes at YEL and for only 100 seconds at EDM.

\section{STUDY METHODS}

Helicopter access allowed field crews to quickly reach deposits over a broad area, beginning at about 1000 on February 3. For the next few days, all deposits remained solidly frozen while field surveys and site examinations were carried out. Initial depositional features were well preserved throughout the field examinations. Frozen bulk samples were insulated and flown back to the laboratory for bulk-density and particle-size analyses.

\section{VOLCANIC PROCESSES AFFECTING SNOWPACK}

Several different types of volcanic processes produced pyroclastic material that interacted with the snowpack during this eruption. Interactions were most intense near 


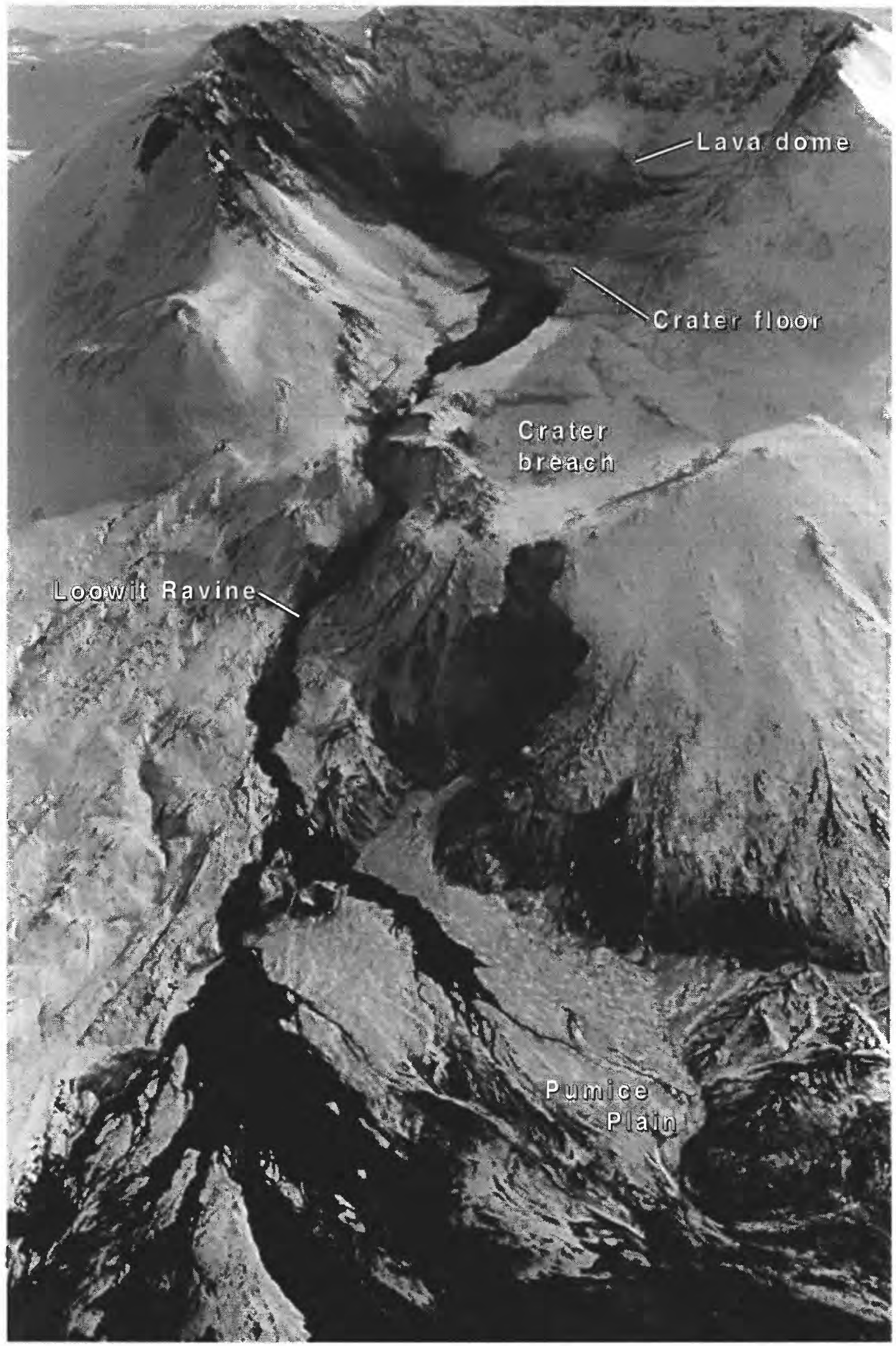

FIGURE 4.2.- Southward oblique aerial view of crater, Loowit Ravine, and Pumice Plain on February 3, 1983, showing darkened, debris-covered east crater wall and path of mixed avalanche and succeeding flows. The crater breach is about 1 kilometer wide. 
the lava dome and were relatively minor outside the crater.

\section{BALLISTIC SHOWER}

Ballistic fragments of hot vesicular dacite at least as large as $0.5 \mathrm{~m}$ in diameter were hurled explosively from a vent on the upper east side of the lava dome (at the head of what subsequently became the rockslide failure scar)(figs. 4.1, 4.4). The fragments were thrown primarily to the northeast, apparently during both of the eruptive bursts. Most of the larger blocks landed within about $350 \mathrm{~m}$ of the vent. During the 0256 burst, a dense pattern of ballistics struck the lower two-thirds of the east crater wall, centered on a prominent rock buttress just northeast of the dome (fig. 4.1). A large proportion of these ballistics were incorporated into the subsequent sediment-water flows. Melt holes from the hot clasts were as much as $1 \mathrm{~m}$ deep and were more abundant outside than inside the margins of the avalanche deposit.

\section{ROCKSLIDE FROM LAVA DOME}

The second eruptive burst on February 3 caused a rockslide of incandescent dacite from the east side of the lava dome to travel about $200 \mathrm{~m}$ out onto the snowcovered crater floor (fig. 4.4). A volume of $10^{4}$ to $10^{5} \mathrm{~m}^{3}$ spread out over an area of about $50,000 \mathrm{~m}^{2}$. The rockslide originated from a deep failure scar heading at the eruptive vent on the upper east side of the dome, into which lava later flowed to form a new lobe on the lava dome.

The pulsing red glow observed near the top of the dome probably emanated from the newly exposed headwall of the landslide scar, and the white cloud that filled the crater soon afterward presumably resulted from increased fumarolic venting from the dome and from steam produced by incandescent rocks contacting snow. The bright incandescence of the new headwall and temperatures measured in cracks in the dome just prior to the eruption indicate that much of the rockslide debris may have been as hot as $900^{\circ} \mathrm{C}$.

\section{ASH CLOUD}

A small ash cloud was generated by the rockslide. The ash-cloud deposit, symmetrical with respect to and lying on top of the rockslide deposit, consisted of thin
( 1 to $3 \mathrm{~cm}$ ), gray lapilli and ash, and it coated about $0.5 \mathrm{~km}^{2}$ of the lower crater wall and crater floor east of the dome in a nearly $90^{\circ}$ sector (fig. 4.4). The deposit overlay and postdated the main snow-avalanche scars. Lapilli proximal to the rockslide scar on the dome graded to coarse ash at the distal margin of the ash-cloud deposit. Most of the lapilli were dense lithic or poorly vesiculated fragments (dome carapace), but the deposit also contained a trace of moderately vesiculated white pumice (presumed juvenile material). The ash-cloud deposit had a relatively sharp outer boundary, indicating flowage rather than pyroclastic fall, and it generally lacked an underlying ice layer, indicating that the presumably hot ash cloud caused little melting of the snow surface and therefore had little effect on the generation of sedimentwater flows.

\section{TEPHRA FALL}

A 1 - to $2-\mathrm{km}$-wide band of thin $(<1 \mathrm{~cm})$ tephra-fall deposit extended northwestward from the lava dome. Fine lithic lapilli near the dome graded outward on the outer flank of the volcano to become coarse ash. Like the thin pyroclastic deposit east of the dome, the proximal tephra-fall deposit just northwest of the dome contained a trace of angular white pumice. The tephra deposit overlay the mixed-avalanche and slushflow deposits, but not the central water-scoured channel. It caused little to no melting of the snow surface and did not contribute to the generation of sediment-water flows.

\section{FLOWS MOBILIZED BY PYROCLAST-SNOW INTERACTIONS}

Four different types of sediment-water flows (some of which contained a significant component of granular ice) resulted from the explosive venting of hot pyroclastic rock debris during the second eruptive burst: mixed avalanche, mixed slushflow, water flow, and debris flow. Flows reached as far as $8 \mathrm{~km}$ from the dome (fig. 4.1).

\section{MIXED AVALANCHE}

The first and largest flow was a mixed avalanche (see Pierson and Janda, 1994), a wet (but apparently unsaturated) avalanche of rock debris and snow, similar to the large avalanche triggered by the March 19, 1982, eruption (Waitt and others, 1983). The main avalanche mass originated as a wet-slab snow avalanche from the 

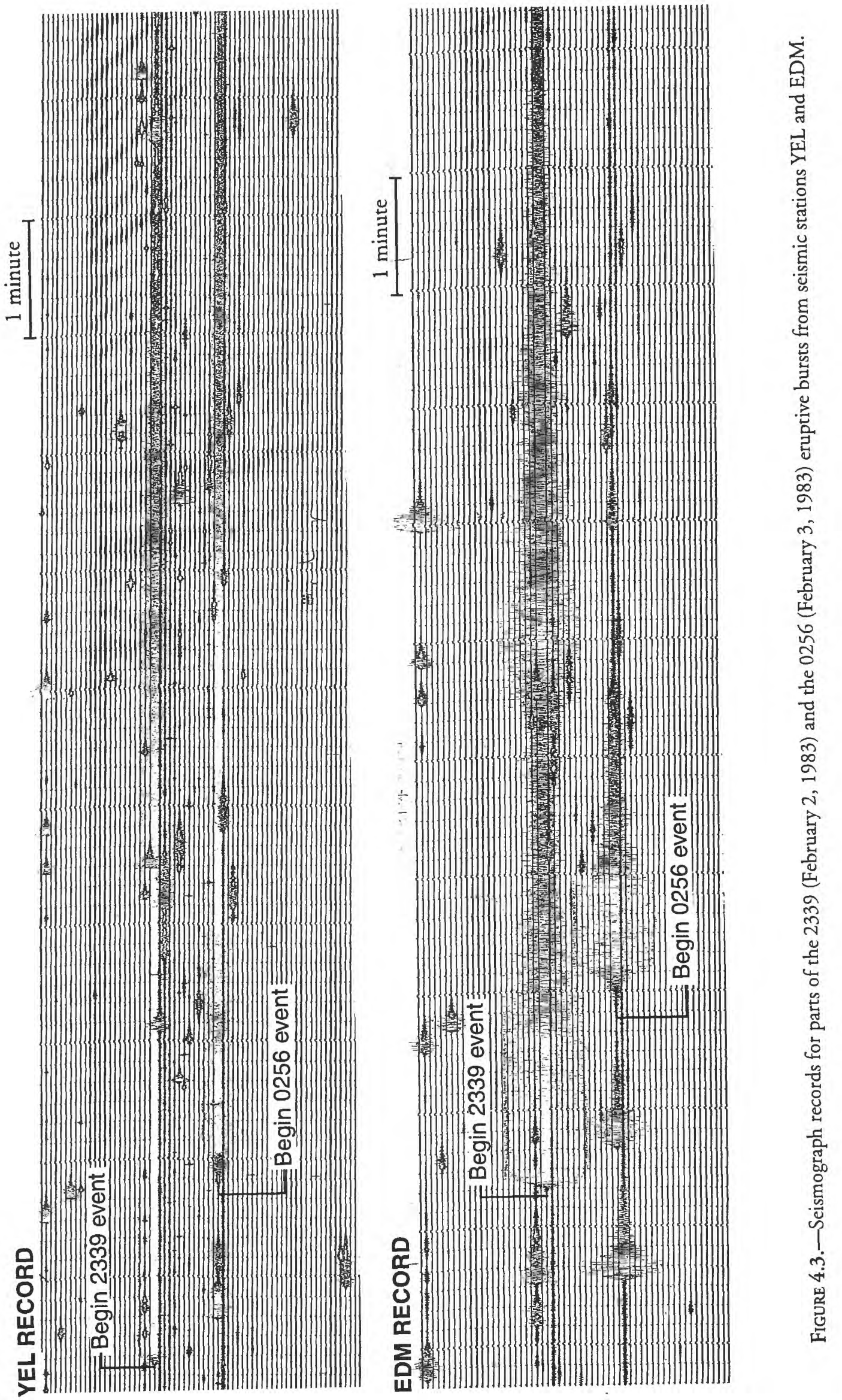
prominent crater-wall buttress northeast of the dome (fig. 4.1) after the snowpack had been bombarded by explosively ejected, hot, pyroclastic debris. The mass of wet snow and incorporated rock debris swept down and spread out on the crater floor, turned clockwise to follow the low topography, and flowed out through the crater breach (figs. 4.1, 4.2, 4.5). Most of the homogenized mixture (roughly $90,000 \mathrm{~m}^{3}$ ) was deposited on the floor of the crater and of the breach, but about 10 percent of the total volume entered Loowit Ravine on the north flank and flowed down that channel. Velocity through the initial turn in the crater was roughly $20 \mathrm{~m} / \mathrm{s}$ $(72 \mathrm{~km} / \mathrm{h})$, as estimated from $9.5 \mathrm{~m}$ of superelevation. Other small snow avalanches were subsequently released off the east crater wall north of the buttress. Only one secondary avalanche reached the main flow path, where it overlay the grooves etched by the main avalanche (fig. 4.5, labelled "late wet-slab snow avalanche").
The mixed-avalanche deposit on the crater floor and in the breach, 12 hours after deposition, was a porous, rough-surfaced sheet ( 0.5 to $2 \mathrm{~m}$ thick) of ungraded, unstratified diamict, consisting of boulder-sized chunks of refrozen, dirty snow studded with dacite boulders (fig. 4.6). It was similar to mixed-avalanche deposits described elsewhere (Pierson and Janda, 1994; Waitt and others, 1994). The mixed-avalanche deposit was firmly ice-cemented, indicating the prior presence of liquid water as a pore fluid. Many hot boulders had melted through the avalanche deposit into underlying snowpack; the larger ones remained warm 12 hours and longer after emplacement. Along most of its route, the avalanche was not significantly erosive, although thin slabs of snow crust were broken and plowed up in places along the margin. In the crater, the deposit appeared to have been emplaced in an unsaturated state; small stones and snowdebris aggregates had broken off from the deposit margin

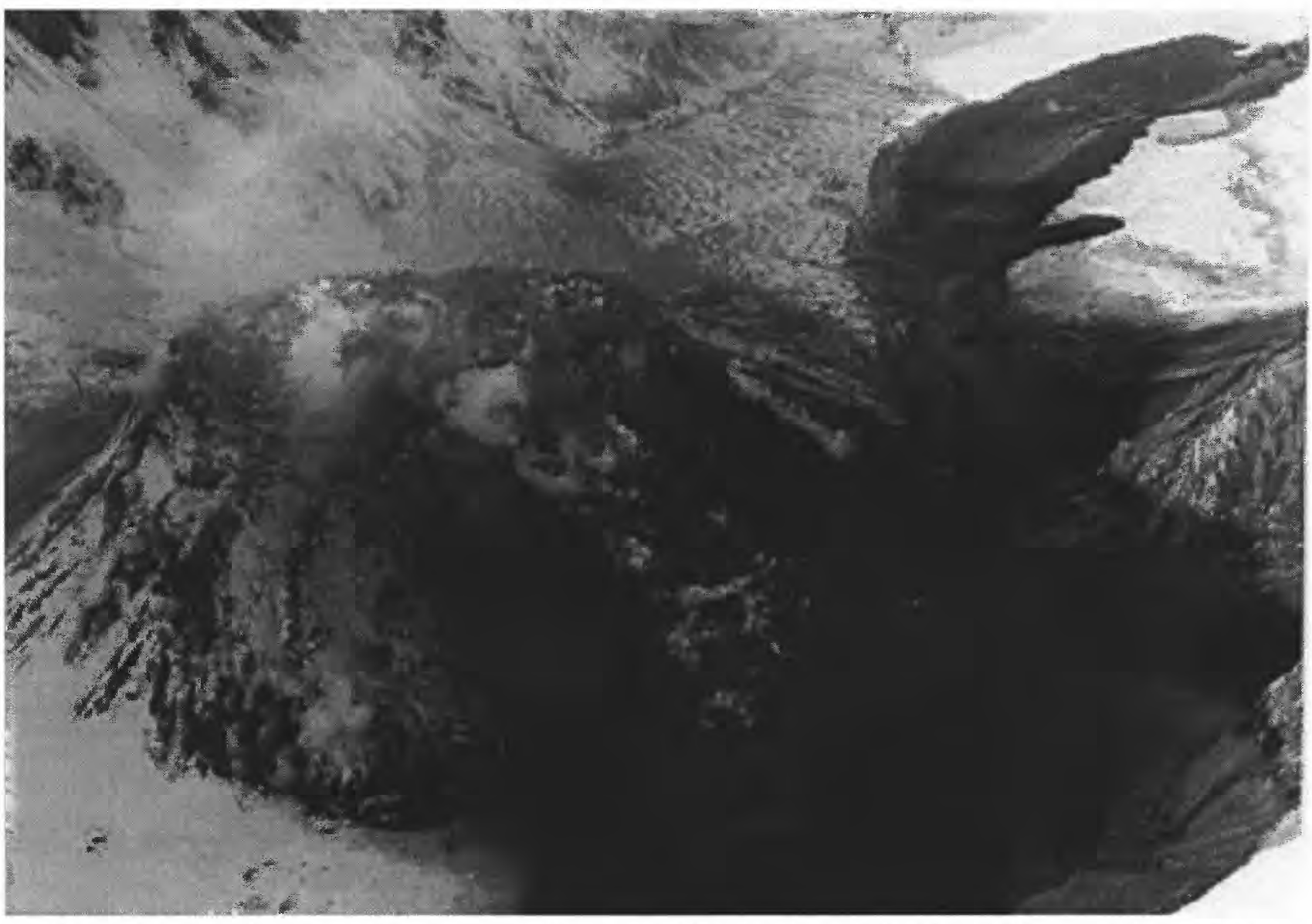

FiguRE 4.4.-Northwestward view of dome on February 3, 1983, showing rockslide deposit (foreground) and mixedavalanche deposit (background) on crater floor. Lava dome is 1,050 meters in diameter. 
in numerous places, indicating a somewhat dry, friable consistency, and no pore water had seeped from the deposit to the adjacent snow.

About $10^{4} \mathrm{~m}^{3}$ of the avalanche material flowed down Loowit Ravine and fanned out on the Pumice Plain as far as $6 \mathrm{~km}$ from the dome (fig. 4.1, 4.2). There the deposit contained lithic clasts as large as $30 \mathrm{~cm}$. As in the crater, the mixed-avalanche deposit had an irregular hummocky surface, although somewhat smoother, and had sporadic flat, very smooth-surfaced areas resulting from localized puddling of saturated slurry, indicating a higher pore-water content on the Pumice Plain than in the crater. Further evidence of a higher degree of saturation of the Pumice Plain deposits were vertical dewatering pipes_-zones of coarser material along which pore water had escaped to the surface of the deposit. In addition, seepage of muddy pore water from the deposit along the margin had stained adjacent undisturbed snow (fig. 4.7). Despite the higher pore-water content and lobate flow margins, both of which are indicative of flowage, the thicker parts of the deposit were disrupted by longitudinal shears and en echelon tensional faults that indicate translational (sliding) movement.
The mixed-avalanche deposit was initially composed of poorly sorted, hot lithic volcanic fragments ranging from clay to boulder size, snow grains as much as several millimeters in diameter, and liquid water. The day after deposition, 2- to 4-kg samples obtained from various locations (fig. 4.1) consisted of about one-quarter rock debris, about one-half granular snow and ice cement, and about one-quarter void space, by volume. Mean bulk density of the samples (excluding clasts larger than $64 \mathrm{~mm}$ ) was $1.10 \mathrm{~g} / \mathrm{cm}^{3}$ (table 4.1), but deposits in the crater and in the breach had lower bulk densities and lower proportions of rock debris than those on the Pumice Plain (table 4.1, fig. 4.8). The bulk-density increase in the Pumice Plain deposits, together with higher rock-fragment concentrations and evidence of extensive pore-water drainage at deposit margins prior to refreezing, seem to indicate that a progressive downslope melting of snow occurred in the mixed avalanche during flow.

Matrix samples of the mixed-avalanche deposit (excluding clasts $>64 \mathrm{~mm}$ ) had an average mean grain size $\left(\mathrm{M}_{\mathrm{Z}}\right)$ of $-1.1 \phi(2.2 \mathrm{~mm})$ and an average sorting coefficient $\left(\sigma_{\mathrm{I}}\right)$ of $3.3 \phi$. They were the coarsest and most

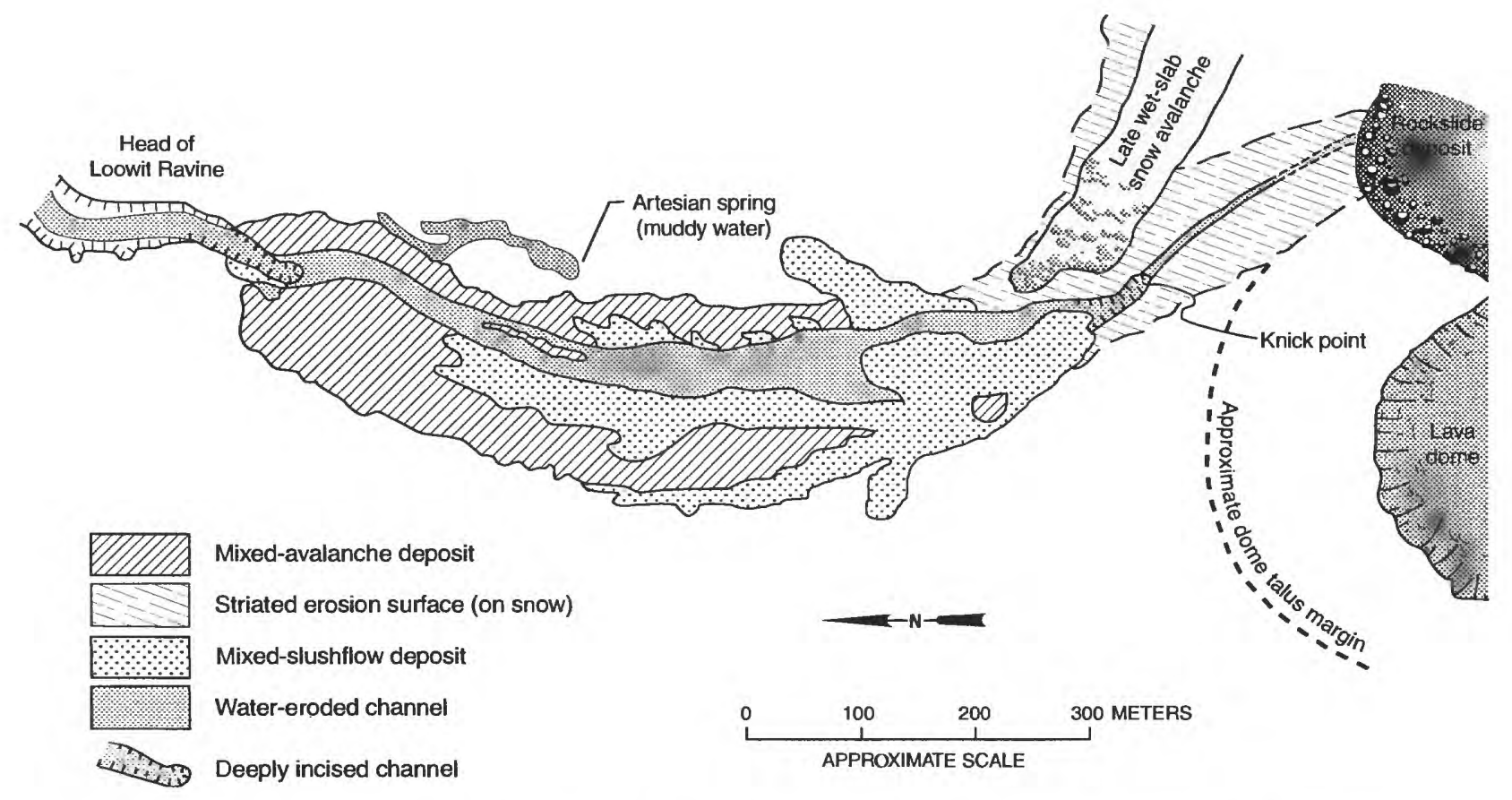

Figure 4.5.-Plan view of flow paths and deposits in crater and breach areas. Map made directly from aerial photographs taken by Oregon Air National Guard. 


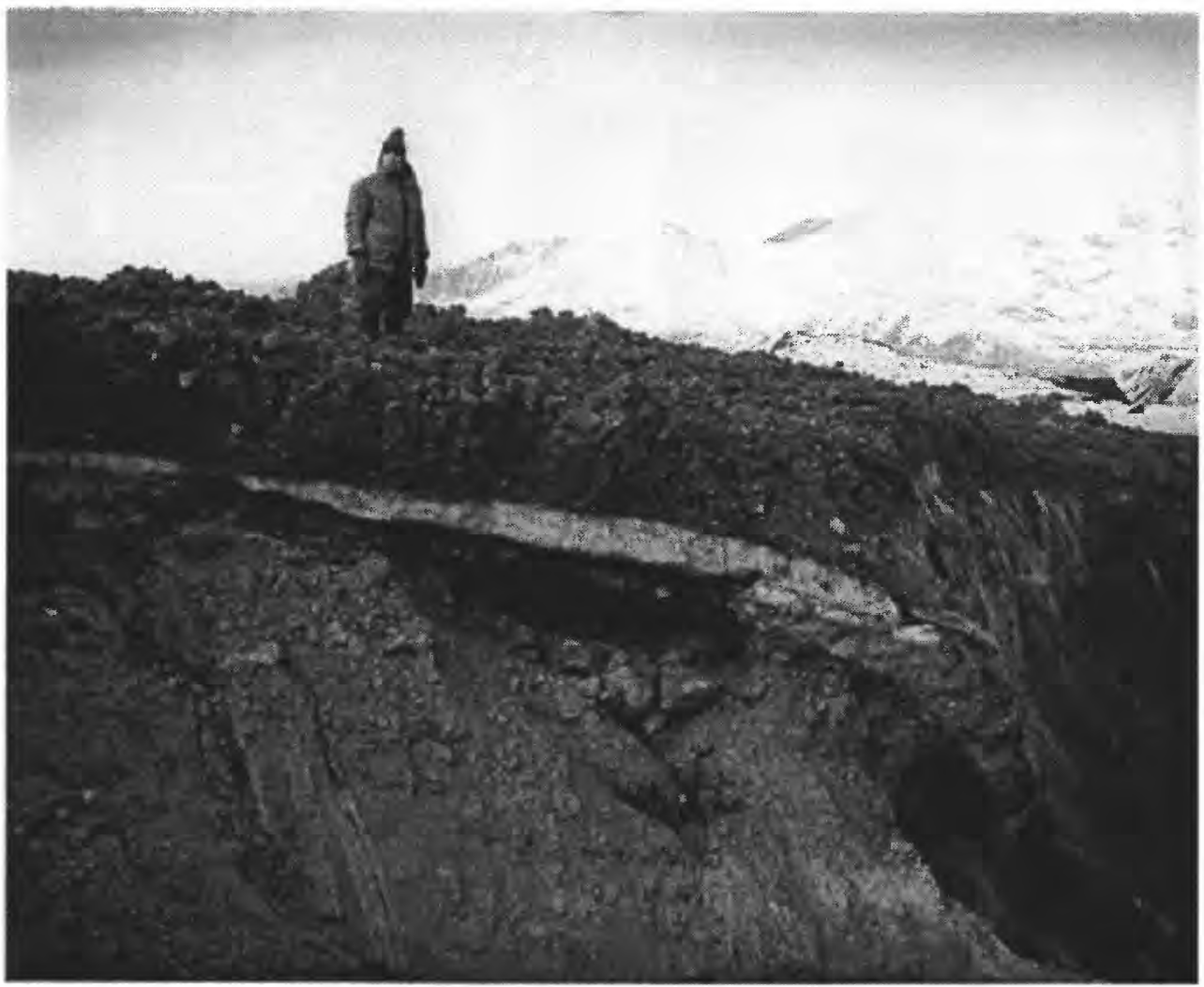

FIGURE 4.6.-Rough-surfaced mixed-avalanche deposit, 80 centimeters thick, overlying snow in lower crater breach at head of Loowit Ravine.

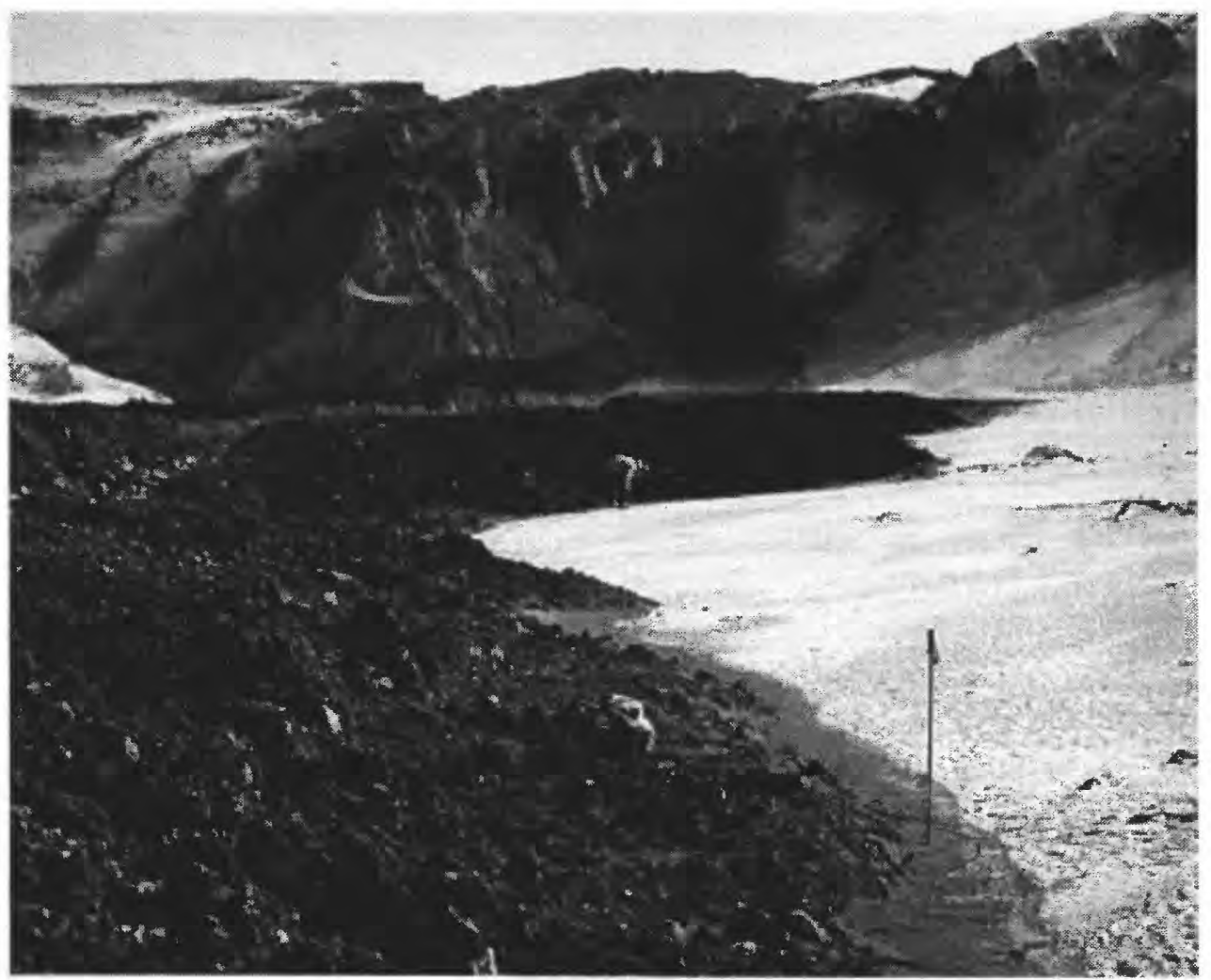

Figure 4.7.- Outer margin of west depositional lobe on Pumice Plain; view up valley showing wet mixed-avalanche deposit and snow stained by escaping muddy pore water. 
TABLE 4.1.-Properties and composition of mixed-avalanche deposit. Sample locations (designated by letter) shown in figure 4.1 [Volume computations made for particle density of $2.4 \mathrm{~g} / \mathrm{cm}^{3}$ and ice density of $0.9 \mathrm{~g} / \mathrm{cm}^{3} ; \mathrm{g}, \mathrm{grams} ; \mathrm{cm}^{3}$, cubic centimeters; km, kilometers; vol. pct., volume percent]

\begin{tabular}{ccccccc}
\hline Sample & $\begin{array}{c}\text { Distance } \\
\text { from } \\
\text { source } \\
(\mathrm{km})\end{array}$ & $\begin{array}{c}\text { Bulk } \\
\text { density } \\
\left(\mathrm{g} / \mathrm{cm}^{3}\right)\end{array}$ & $\begin{array}{c}\text { Rock } \\
\text { clasts, } \\
\mathrm{R} \\
(\text { vol. pct.) }\end{array}$ & $\begin{array}{c}\text { Ice, I } \\
\text { (vol. pct.) }\end{array}$ & $\begin{array}{c}\text { Void } \\
\text { space } \\
\text { (vol. pct.) }\end{array}$ & $\frac{\mathrm{R}}{\mathrm{R}+\mathrm{I}}$ \\
\hline $\mathrm{J} 1$ & 0.9 & 0.84 & 18 & 46 & 36 & 0.28 \\
$\mathrm{I} 1$ & 1.5 & 1.01 & 15 & 71 & 14 & 0.17 \\
$\mathrm{D} 1$ & 4.4 & 1.10 & 28 & 48 & 24 & 0.37 \\
$\mathrm{C} 1$ & 4.4 & 1.32 & 36 & 50 & 14 & 0.42 \\
$\mathrm{C} 2$ & 4.4 & 1.18 & 36 & 36 & 28 & 0.50 \\
$\mathrm{E} 1$ & 4.7 & 1.14 & 32 & 42 & 26 & 0.43 \\
\hline
\end{tabular}

${ }^{1}$ Source arbitrarily defined as base of east crater wall at the rock buttress.

poorly sorted of the sediment-water flows produced during this eruption (table 4.2, fig. 4.9). The character of the mixed-avalanche deposit changed drastically within a few weeks, due to melting of the ice component. After complete melting and drying, the deposit was only a few tens of centimeters thick and was extremely loose and friable.

\section{MIXED SLUSHFLOW}

Another deposit of water, snow, and rock debris was found refrozen and nested within levees of the mixedavalanche deposit; its form indicated that it had been a mixed slushflow-wetter and more fluid than the mixed

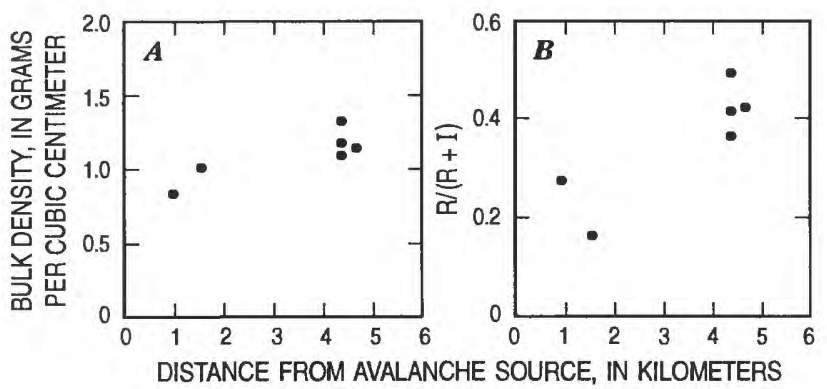

FigURE 4.8.-Components of mixed-avalanche deposit: $A$, Plot of sample bulk density versus distance from avalanche source (rock buttress on east crater wall); $B$, rock fragments in mixed-avalanche deposit as a fraction of total solids (rock + ice) versus distance from avalanche source. avalanche. Contacts between the two units were gradational in some places and sharp in others (fig. 4.5). The mixed slushflow, probably a wetter, tail-end phase of the mixed avalanche, did not seem to have been totally liquefied while flowing in the crater; its deposit, compared to the mixed-avalanche deposit, was only moderately smoother, thinner, and more digitate at its lateral margins. On the Pumice Plain, however, the mixed slushflow behaved as a fully liquefied slurry. The contacts were sharp where mixed-slushflow deposits were confined by levees of the mixed-avalanche deposit. Mixed-slushflow deposits were thinner than the mixedavalanche deposits and extended farther down the Pumice Plain, where they spread out as thin, lobate sheets beyond the confining levees. Copious amounts of muddy water seeped into the snow all along the margins of the mixedslushflow, which indicates that the mixed-slushflow deposit dewatered far more than did the mixed-avalanche deposit. Matrix samples of the mixed-slushflow deposit (particles $>64 \mathrm{~mm}$ not analyzed) had variable grain-size distributions but were finer grained and generally better sorted than the mixed-avalanche samples; they had an average mean grain size of $0.9 \phi(0.5 \mathrm{~mm})$ and average sorting coefficient of $2.7 \phi$ (table 4.2).

\section{WATER FLOW AND DEBRIS FLOW}

A flow consisting almost entirely of water followed the mixed slushflow in the crater, incising a channel 2 to $4 \mathrm{~m}$ through the mixed-slushflow deposits and the 
MIXED-AVALANCHE DEPOSITS
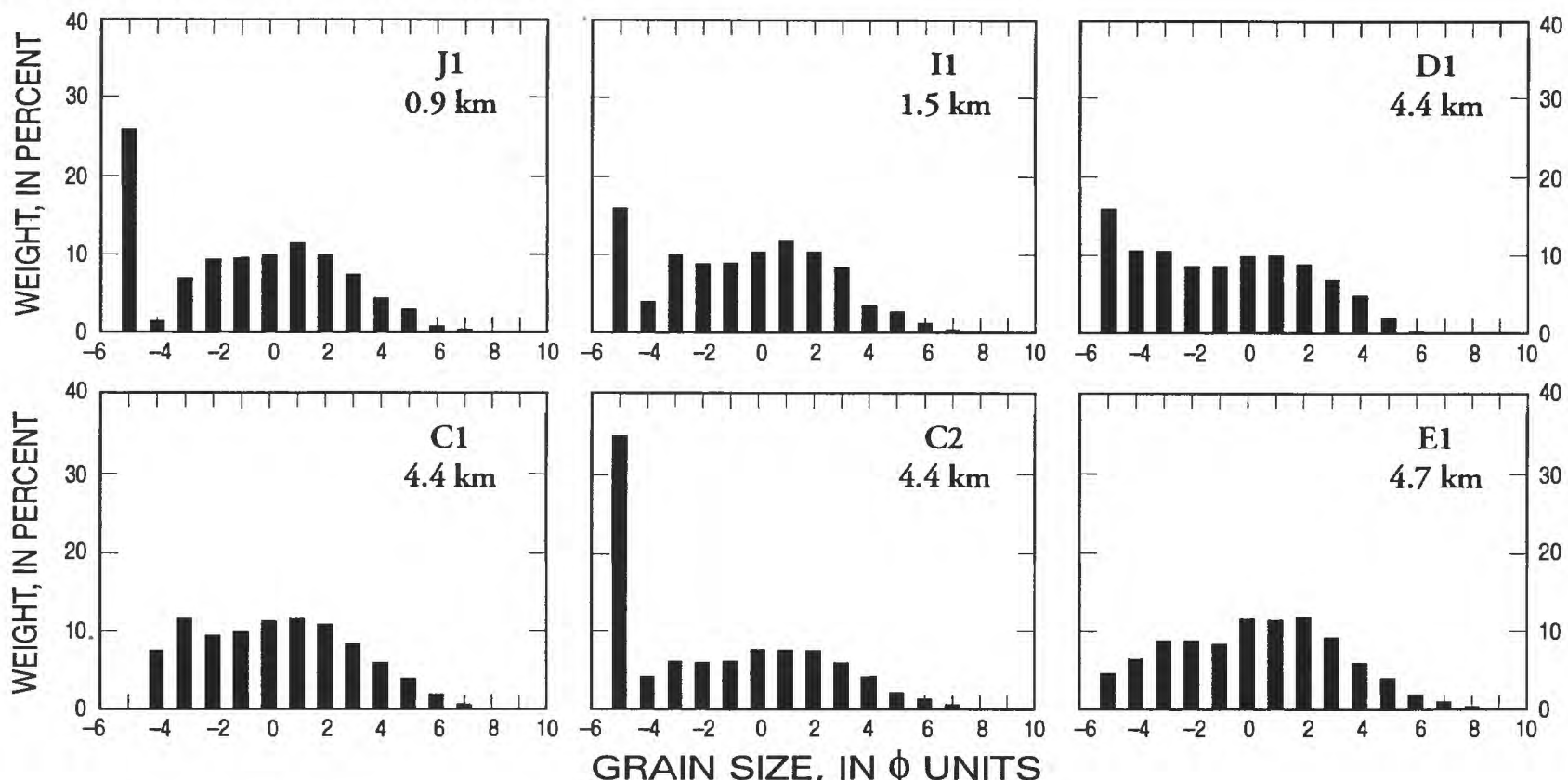

MIXED-SLUSHFLOW DEPOSITS
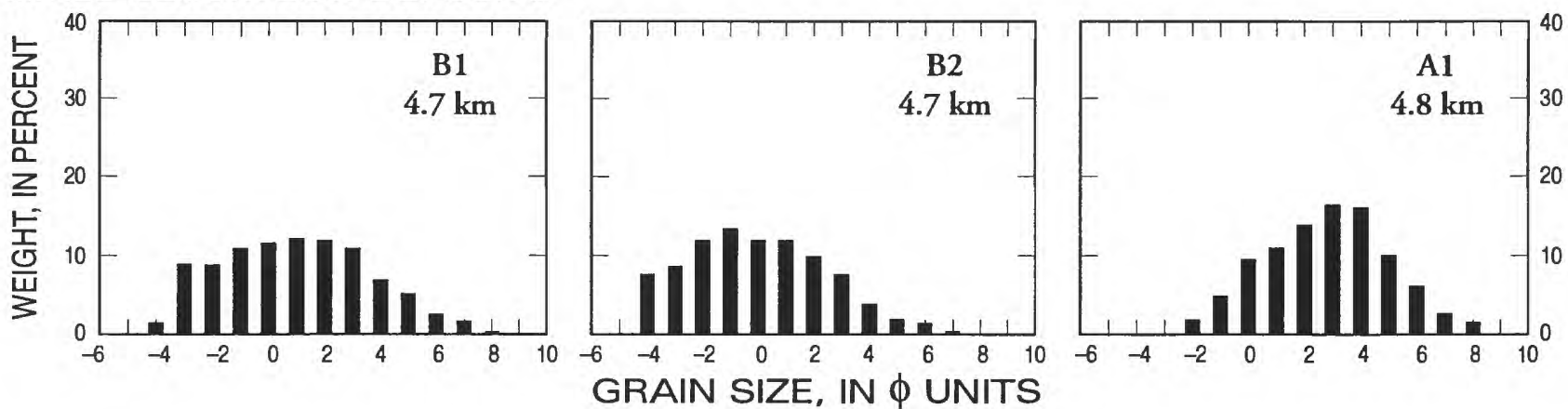

GRAIN SIZE, IN $\phi$ UNITS

\section{DEBRIS-FLOW DEPOSITS}
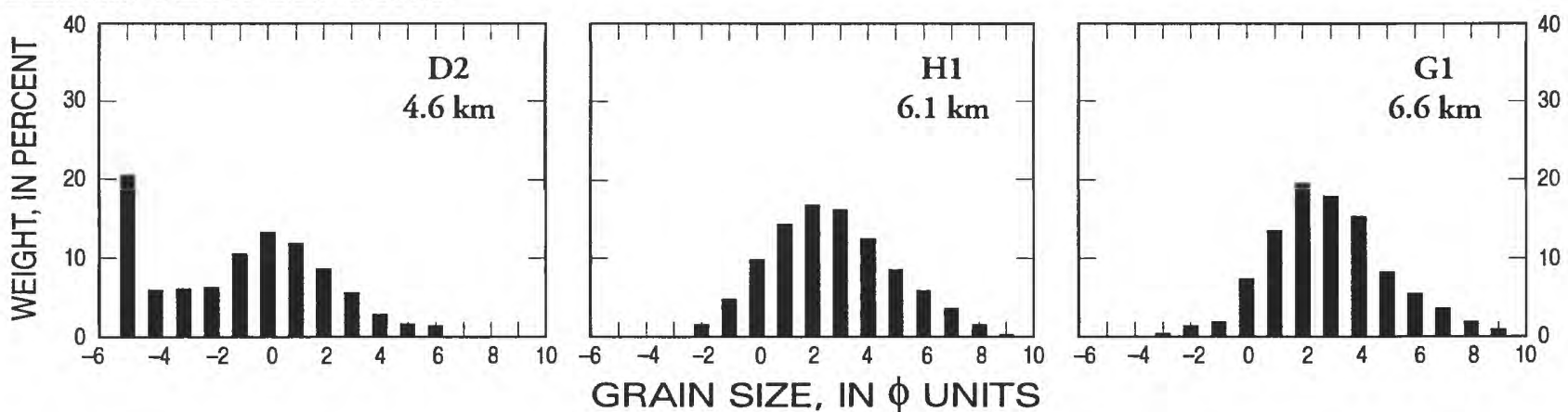

Figure 4.9.-Grain-size frequency histograms for mixed-avalanche, mixed-slushflow, and debris-flow deposits. Clasts coarser than $32 \mathrm{~mm}(-5 \phi)$ not sampled. Distances downslope from rock buttress on east crater wall are indicated. 
TABLE 4.2.-Grain-size parameters 1 of mixed-avalanche, mixed-slushflow, and debris-flow deposits [km, kilometers; $\emptyset$, negative logrithm of grain diameter in millimeters to base 2.]

\begin{tabular}{|c|c|c|c|c|c|}
\hline Sample & $\begin{array}{c}\text { Distance } \\
\text { from } \\
\text { source }^{2} \\
(\mathrm{~km})\end{array}$ & $\begin{array}{c}\text { Mean } \\
\text { grain } \\
\text { size, } \\
(\phi)\end{array}$ & $\begin{array}{c}\text { Sorting, } \\
\sigma_{I} \\
(\phi)\end{array}$ & $\begin{array}{c}\text { Skewness, } \\
\text { SK }_{\mathrm{I}}\end{array}$ & $\begin{array}{c}\text { Kurtosis, } \\
\mathrm{K}_{\mathrm{G}}\end{array}$ \\
\hline \multicolumn{6}{|c|}{ Mixed Avalanche } \\
\hline J1 & 0.9 & -1.47 & 3.38 & -0.03 & 0.65 \\
\hline I1 & 1.5 & -1.11 & 3.35 & -0.07 & 0.82 \\
\hline D1 & 4.4 & -1.52 & 3.22 & 0.09 & 0.75 \\
\hline $\mathrm{C} 1$ & 4.4 & -0.14 & 3.00 & 0.04 & 0.86 \\
\hline $\mathrm{C} 2$ & 4.4 & -1.97 & 3.46 & 0.27 & 0.67 \\
\hline E1 & 4.7 & -0.26 & 3.13 & -0.03 & 0.88 \\
\hline Average & & -1.08 & 3.26 & 0.05 & 0.77 \\
\hline \multicolumn{6}{|c|}{$\underline{\text { Slushflow }}$} \\
\hline B2 & 4.7 & -0.08 & 2.88 & 0.03 & 0.92 \\
\hline $\mathrm{B} 1$ & 4.7 & 0.54 & 2.90 & 0.05 & 0.91 \\
\hline Al & 4.8 & 2.36 & 2.38 & -0.02 & 0.99 \\
\hline Average & & 0.94 & 2.72 & 0.02 & 0.94 \\
\hline \multicolumn{6}{|c|}{ Debris Flow } \\
\hline D2 & 4.6 & -1.56 & 3.18 & -0.07 & 0.76 \\
\hline H1 & 6.1 & 2.23 & 2.45 & 0.11 & 1.02 \\
\hline G1 & 6.6 & 2.34 & 2.26 & 0.09 & 1.09 \\
\hline Average & & 1.00 & 2.63 & 0.04 & 0.96 \\
\hline
\end{tabular}

${ }^{1}$ Units of Folk and Ward (1957); see also Folk (1966, 1974).

${ }^{2}$ Source arbitrarily defined as base of east crater wall at the rock buttress.

underlying snowpack into the pumiceous crater-floor deposits (fig. 4.10). Channel sides were glazed with dirty, dense ice as thick as $5 \mathrm{~cm}$. Localized deposition of noncohesive sandy gravel as thick as $0.5 \mathrm{~m}$ on the channel floor indicates that the agent of this downcutting was normal streamflow; flow magnitude was sufficient to transport boulders as large as $1.5 \mathrm{~m}$ in diameter. The incised channel could be traced back almost to the margin of the rockslide deposit, which indicates that much of the flow was meltwater produced by heat from this debris.

On the Pumice Plain, evidence for a substantial water flow was lacking. Instead, the mixed-slushflow deposits seemed to have been eroded by dilute debris flow, as evidenced by thin mud coatings on boulders in the channels. The debris flow presumably evolved when water being discharged from the crater bulked up with debris that the water eroded as it descended Loowit Ravine. Like the mixed-slushflow, the debris flow also contained some snow granules, although these formed a smaller proportion of the solid component. Unlike the other deposits, however, the debris-flow deposit contained oxide-stained pumice derived from downcutting at the crater breach (fig. 4.2). Samples of the debris-flow deposit finer than $64 \mathrm{~mm}$ were similar to the mixed-slushflow deposits in texture, had an average 


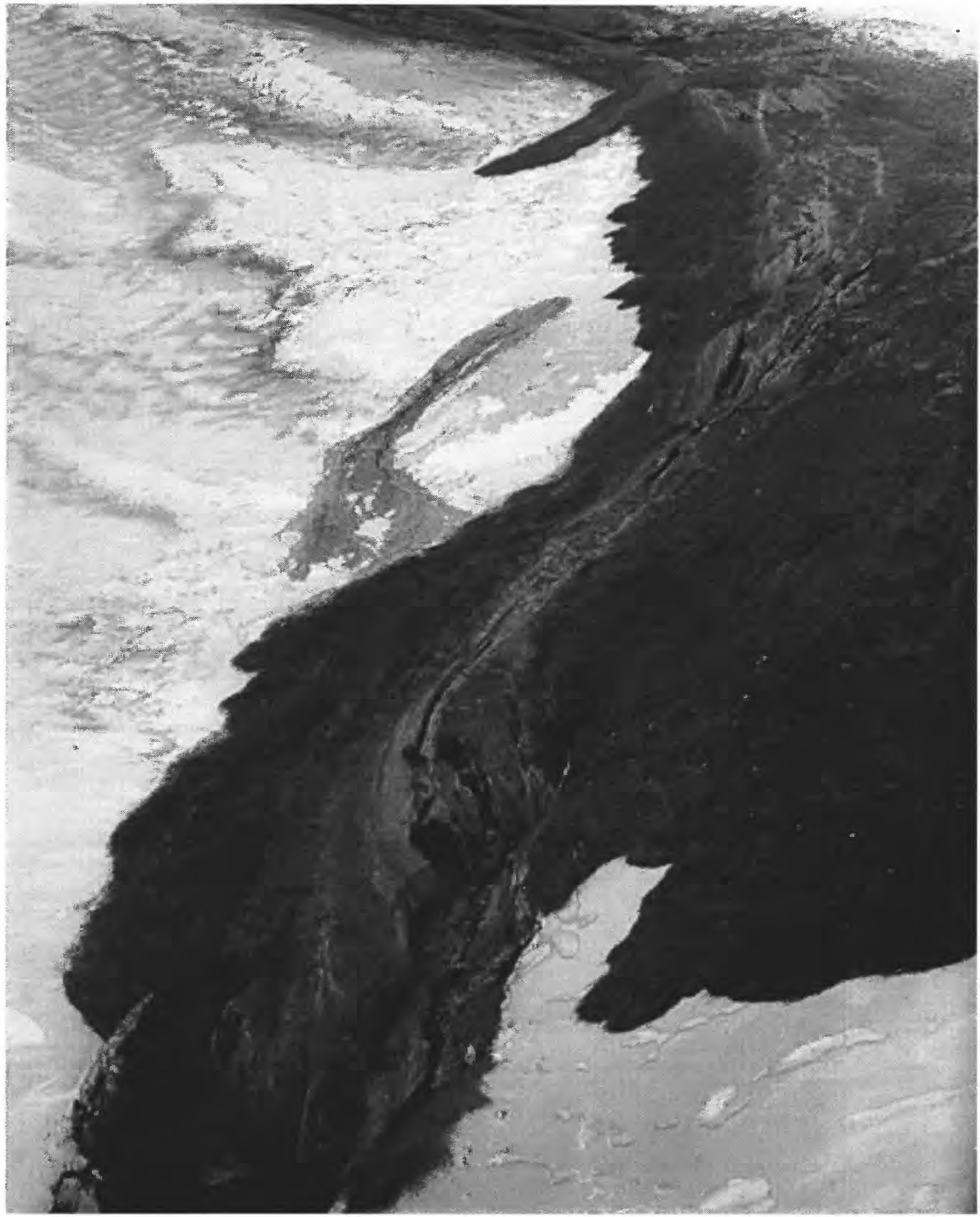

FIGURE 4.10.-Nested nature of mixed-avalanche, mixed-slushflow, and water-flow deposits, visible from subtle tonal and textural changes, and water-eroded channel, in crater breach at head of Loowit Ravine. View is upslope and southward; see figure 4.5 for scale. Some meltwater had piped through the snowpack to emerge as a muddy spring (upper center of photograph). 
mean grain size of $1.0 \phi(0.5 \mathrm{~mm})$, and had an average sorting coefficient of $2.6 \phi$ (table 4.2). The sorting values of the distal debris-flow samples indicate that the debris flow was very dilute and almost transitional to hyperconcentrated flow. The debris-flow deposits also were well drained and fairly porous; bulk density of one frozen sample (site $\mathrm{H}$ ) was $1.3 \mathrm{~g} / \mathrm{cm}^{3}$.

The debris flow issued from the steep channel of Loowit Ravine at a fairly low discharge and did not have the competence to transport boulders much beyond the confining levees of the mixed-avalanche and mixed slushflow deposits, although fine-grained slurries flowed as far as Spirit Lake (fig. 4.1). Strand lines at the head of the Pumice Plain (site D1 in fig. 4.1) showed a flow width of about $25 \mathrm{~m}$ and a peak-flow depth of a little more than $1 \mathrm{~m}$. A slope-conveyance calculation for this cross section, assuming Manning's $n=0.03$, gives an approximate discharge of $250 \mathrm{~m}^{3} / \mathrm{s}$ and a velocity of $8.8 \mathrm{~m} / \mathrm{s}$. Runup of debris on a large boulder and channel superelevation at sites $H$ and $G$ (fig. 4.1) indicated minimum velocities of 3.4 and $3.3 \mathrm{~m} / \mathrm{s}$. A relatively low discharge for the debris flow is consistent with the observation that, while descending Loowit Ravine, the debris flow did not overflow into the channel to the west as the mixed avalanche and mixed slushflow did.

\section{SEQUENCE AND TIMING OF FLOWS}

The inferred sequence and timing of flows is constrained by the seismic records, the eye-witness accounts, and the field relations of eroded areas and deposits. The mixed-avalanche deposit contained hot blocks that had been emplaced prior to deposition of the mixed avalanche, implying that the ballistic shower preceded avalanching from the crater wall. Snow striations left by the mixed avalanche terminated at the foot of the rockslide deposit, and the surface of that deposit did not seem to be eroded (fig. 4.5), indicating that the dome-collapse rockslide must have followed the mixed avalanche. Thus, the sequence must have been (1) ballistic shower, (2) mixed avalanche, and (3) dome rockslide.

All three events must have occurred within about 5 minutes of 0256 because that was the duration of the high-amplitude seismicity at the YEL seismic station in the crater; each of the three events is presumed sufficient to have caused a seismic signal but their signals would have been largely masked by the high-amplitude signals caused by the explosive venting during the second burst. The timeframe within which the three events occurred is also constrained by the eyewitness report of the appearance of the pulsing red glow (glowing rockslide headwall) "about 5 minutes" after sighting the emission plume. The 50 seconds of high-amplitude seismicity recorded by the EDM seismometer is probably the vigorous venting that caused the ballistic shower, and a 30-second, cigar-shaped seismic signal about 4 minutes later (not shown in fig. 4.3) may be the rockslide from the dome. The observed white cloud within the crater, noted after the pulsing red glow was seen on the dome, is interpreted to be steam produced by very hot rockslide debris contacting snow. This cloud then was followed by the sighting of a dark flow (time not recorded) exiting the crater.

Some type of flow, presumably the mixed slushflow or debris flow or both, continued for about one-half hour after the intense seismicity at the beginning of the 0256 eruptive burst, because both seismometers recorded a gradually diminishing, low-amplitude, high-frequency signal until about 0328 . This signal was similar to seismograms known to be caused by debris flows (Pierson, 1986). Thus, all major flow events seem to have occurred by about 0330 ; the mixed-avalanche deposit was confirmed to be in place during a pre-dawn observation flight at 0530 .

\section{SOURCE AND EFFECTS OF MELTWATER}

The main meltwater channel headed at the hot rockslide deposit. Meltwater could have been produced by a combination of (1) melting crater snowpack from beneath the hot rockslide deposit, (2) late snow avalanches that landed on the deposit, and (3) melting from the crater walls that were being subjected to radiant heating from the $-900^{\circ} \mathrm{C}$ rockslide headscarp only 700 to $800 \mathrm{~m}$ away. Rilling from running water was evident at the base of the east crater wall.

Meltwater flowing from the east side of the dome seemed to have encountered the mixed-avalanche deposit blocking its path. The upstream end of the avalanche deposit and parts adjacent to the eroded channel appeared to have been much wetter than the rest of the mixedavalanche deposit (fig. 4.5). Some meltwater was diverted under the snowpack and emerged as a spring farther downslope (fig. 4.5). The mixed-avalanche deposit seemed to have served simultaneously as a sponge and as a dam that temporarily impeded the flow of meltwater. Once sufficiently saturated, the core of the mixedavalanche deposit along the axis of meltwater flow became 
partly liquefied and remobilized as the mixed slushflow. Saturation of the original, relatively dry deposit by later meltwater would account for the gradational contact between the dry- and wet-looking deposits in the crater and for the sharp contacts between these deposits farther downslope on the Pumice Plain. Once the flow path through the mixed-avalanche deposit had been cleared, flowing meltwater began eroding into the crater floor.

\section{SIMILARITY TO EVENTS OF MARCH 19, 1982}

The February 2-3, 1983, eruption was similar to the eruption that occurred on March 19, 1982 (Waitt and others, 1983; Pierson and Scott, 1985; chap. 2, this volume), but the earlier eruption was larger and occurred without a rockslide from the dome. The other main difference between these eruptions was that meltwater produced in 1982 accumulated in a large transient lake in the crater before being released; consequently, the resulting flood and debris flow were substantially larger. Such a lake might have formed in 1983, as well, if the eruptive bursts had been aimed more southward. Egress of sediment-water flows from the southern end of the crater is partly blocked by the dome itself, and greater accumulations of snow at that end provide a potentially abundant source of meltwater.

\section{MIXED-AVALANCHE INITIATION MECHANISMS}

Five mechanisms could have triggered the snow-slope failures that produced the mixed avalanche (Pierson and Janda, 1994): (1) seismic or acoustic destabilization, (2) generation of destabilizing pore-water pressures in the snowpack from melting by imbedded ballistic fragments, (3) destabilization by stress imparted to the snow by ballistic impacts (inertial loading), (4) destabilization by the added weight of the ballistic fragments to the slope (gravitational loading), and (5) loss of snow-slab tensile strength due to decreases in cohesion (from localized melting and meltwater infiltration). The last three of these mechanisms are probably responsible for snow avalanches that commonly occur immediately after rain begins falling on snow slopes, as suggested by Conway and Raymond (1993). A single mechanism could have triggered the mixed avalanches, or several mechanisms possibly could have acted together.

The first mechanism seems improbable because the earlier 2339 eruptive burst, which was seismically and presumably acoustically more vigorous than the 0256 burst, did not produce significant avalanching. Remnant deposits of early snow avalanches (occurring prior to the mixed avalanche) were not observed, which indicates that stress-wave propagation in the snowpack from earthquakes or air-pressure waves would have been insufficient to cause snow-slope failures during the smaller 0256 eruptive burst. Furthermore, seismic or acoustic shock should have released avalanches in locations unrelated to ballistic-impact patterns on the crater wall, but in this case, snow avalanche scars were concentrated in the areas most heavily bombarded by ballistics during the 0256 eruptive burst.

The spatial coincidence of ballistic impacts with snow-avalanche failure scars supports a causal connection between ballistic impact and snowpack destabilization. The rapidity of seismic events after the beginning of the 0256 eruptive burst indicates that less than five minutes elapsed from the time ballistic fragments burrowed into the snow slopes until failures occurred. A similar, very rapid response of snow avalanching to rainfall has been documented by Conway and Raymond (1993), where snow-slab failures 30 to $50 \mathrm{~cm}$ deep occurred sometimes within minutes of the onset of rain, when liquid water and heat had penetrated only 5 to $10 \mathrm{~cm}$ into the snow. Weakening of snow-grain bonds by meltwater or buildup of pore-water pressures in the snowpack might have a destabilizing effect within 5 minutes only if the snow was already thoroughly wetted (Conway and Raymond, 1993). The slightly subfreezing temperatures on February 2-3 probably would not have allowed the upper snow layers on the crater walls to be that wet.

The rapid onset of avalanching following the beginning of the 0256 eruptive burst indicates that the avalanches were triggered by inertial loading by ballistics striking the snow surface, gravitational loading by the weight of the accumulating ballistic particles, or reduction of tensile strength in the snowpack by melting and weakening of the snow surface (or some combination of the three).

\section{SUMMARY}

Like the March 19, 1982, eruption, the February 2-3, 1983 eruption in the crater of Mount St. Helens triggered a rapid sequence of sediment-water flows involving snow, hot rock debris, and water. Also like the 1982 eruption, the 1983 eruption first produced a massive mixed avalanche that reached as far as $6 \mathrm{~km}$ 
and temporarily held back subsequently produced meltwater in the crater. In 1983, the smaller of two, otherwise similar, explosive bursts produced the flows, indicating that snowmelt flow hazards may not be directly related to eruption magnitude but rather to the relative effectiveness of hot-rock emplacement on snow slopes. Therefore, a larger eruption is not necessarily more hazardous than a smaller one. Although a single, primary avalanche-release mechanism could not be identified, avalanche triggering occurs rapidly and seems to be directly related to the ballistic fragments that hit the snow slopes.

\section{REFERENCES CITED}

Conway, Howard, and Raymond, C.F., 1993, Snow stability during rain: Journal of Glaciology, v. 39, no. 133, p. 635-642.

Fisher, R.V., and Schmincke, H.-U., 1984, Pyroclastic rocks: New York, Springer-Verlag, $472 \mathrm{p}$.

Folk, R.L. 1966, A review of grain-size parameters: Sedimentology, v. 6, no. 2, p. 73-93.

Folk, R.L., 1974, Petrology of sedimentary rocks (2nd ed.): Austin, Hemphill's, 182 p.

Folk, R.L., and Ward, W.C., 1957, Brazos River bar [Texas]-A study in the significance of grain size parameters: Journal of Sedimentary Petrology, v. 27, no. 1, p. 3-26.
Pierson, T.C., 1986, Flow behavior of channelized debris flows, Mount St. Helens, Washington, in Abrahams, A.D., ed., Hillslope processes: Boston, Allen and Unwin, p. 269-296. [Binghamton Symposia in Geomorphology_International Series, v. 16.]

Pierson, T.C., and Janda, R.J., 1994, Volcanic mixed avalanches: A distinct eruption-triggered mass-flow process at snow-clad volcanoes: Geological Society of America Bulletin, v. 106, no. 10, p. 1351-1358.

Pierson, T.C., and Scott, K.M., 1985, Downstream dilution of a lahar; transition from debris flow to hyperconcentrated streamflow: Water Resources Research, v. 21, no. 10, p. 1511-1524.

Waitt, R.B. Jr., Pierson, T.C., MacLeod, N.S., Janda, R.J., Voight, Barry, and Holcomb, R.T., 1983, Eruptiontriggered avalanche, flood, and lahar at Mount St. Helens-effects of winter snowpack: Science, v. 221, no. 4618, p. 1394-1397.

Waitt, R.B., Gardner, C.A., Pierson, T.C., Major, J.J., and Neal, C.A., 1994, Unusual ice diamicts emplaced during the December 15, 1989 eruption of Redoubt Volcano, Alaska: Journal of Volcanology and Geothermal Research, v. 62, no. 1-4, p. 409-428.

Wentworth, C.K., 1922, A scale of grade and class terms for clastic sediments: Journal of Geology, v. 30, no. 5, p. 377-392. 


\title{
ROCK AVALANCHES, ROCKFALLS, AND ASSOCIATED PROCESSES INDUCED BY SPREADING OF THE LAVA DOME, MARCH 1984
}

\author{
By Jon J. Major and Patrick T. Pringle ${ }^{1}$
}

\section{CONTENTS}

Abstract

Introduction

69

Events in March 1984 ........................................... 70

Terminology ...................................................... 70

Timing of rock avalanches and rockfalls ..................... 72

Deposits of the rock avalanche-rockfall complex ........... 73

Unit A ............................................................... 73

Units B1 and B2 .............................................. 74

Unit C .......................................................... 75

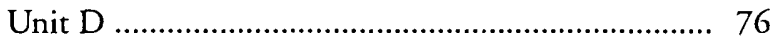

Boundary deposits ........................................... 76

Causes of rock avalanches and rockfalls ..................... 76

Implications for future mass failures ........................ 79

Conclusions ........................................................ 79

Acknowledgments ................................................ 80

References cited .............................................. 80

\section{ABSTRACT}

On March 29, 1984, intrusion of new magma caused rapid spreading and extensive cracking of the north flank of the Mount St. Helens lava dome, which culminated in a series of small rock avalanches and rockfalls (total volume approximately $10^{5}$ cubic meters). The resulting avalanche and fall deposits consist of five main units: a thin, coherent, basal diamict (unit A); several overlapping, dry, noncohesive sand-rich deposits that contain dispersed pebbles and boulders (broadly grouped as units B1 and B2); a thin, generally massive deposit of silty, fine sand that mantles much of the avalanche fan (unit C); and talus composed of boulders several meters in size (unit D). The suite of deposits is bounded by a fringe of fine sand and dirty snow.

The initial avalanche, recorded by unit $A$, is attributed to failure of the cold, snow-clad, brittle shell of the dome; units B1 and B2 record several subsequent failures of newly exposed hot rock that lay beneath the shell; and unit D records spalling of older dome rock and newly extruded lava for several days after the initial mass failure. The mantle of massive, silty sand (unit C) is attributed to a small pyroclastic flow and to fallout of fine tephra generated by disaggregation of the hot-rock avalanches. The boundary deposit is attributed to a combination of pyroclastic flow, tephra fall, and runout of a dilute slurry and dirty water.

Snow provides an abundant water source that exacerbates the potential lahar hazard to sites down valley if hot-rock avalanches and associated disaggregation processes cause the snow to melt rapidly. However, more energetic, much hotter, or much larger rock avalanches than those of March 1984 are needed to produce associated meltwater flows that would affect areas much beyond the crater. Without the presence of a snowpack, rock avalanches must be substantially larger or more energetic than those of March 1984 to pose a threat beyond the crater.

\section{INTRODUCTION}

Rock avalanches and rockfalls originating from the composite lava dome of Mount St. Helens since 1980 typically occur in one of three ways: (1) during periods of renewed eruptive activity as a result of extensive fracturing and weakening of the dome caused by

\footnotetext{
${ }^{1}$ Current address: Washington Division of Geology and Earth Resources, P. O. Box 47007, Olympia, WA $98504-7007$
} 
intrusion of new magma; (2) by rock spalling from the leading edge of newly extruded lava that has encroached on the steep slopes of the dome; or (3) by earthquakeinduced collapse unrelated to eruptive activity. Typically, the volume of failed material is small $\left(<10^{4}-10^{5} \mathrm{~m}^{3}\right)$ compared to the volume of the dome (over $10^{8} \mathrm{~m}^{3}$ in 1986), and most of the debris that is shed is deposited as talus at the base of the dome. However, rock avalanches and rockfalls from the lava dome occasionally are sufficiently large and mobile that they reach onto and spread across a part of the crater floor. Rock avalanches and rockfalls from the dome that occur while the crater floor is snow free affect only the crater and generally pose little hazard beyond the immediate area, even if they are hot. However, when hot-rock avalanches and rockfalls occur while snowpack is present they can induce meltwater flows that may reach beyond the crater. Since 1980 , several small eruptions of Mount St. Helens have generated flood surges, slushflows, or mixed avalanches of snow and debris that commonly have eroded large amounts of sediment and transformed into lahars (volcanic debris flows) that flowed beyond the crater and into the North Fork Toutle River (fig. 5.1) (Waitt and others, 1983; Pierson and Scott, 1985; Cameron and Pringle, 1990; Pierson and Janda, 1994; Pierson, chap. 2, this volume; Pierson and Waitt, chap. 4, this volume; Pringle and Cameron, chap. 6, this volume).

\section{EVENTS IN MARCH 1984}

Rock avalanches and rockfalls accompanying an eruption on March 29, 1984, illustrate failures that occur by weakening of the lava dome when new magma is actively injected into the dome, and by spalling of rock from the leading edge of a lobe of newly extruded lava that has encroached on the steep slopes of the dome. The eruption was preceded by about eight days of precursory seismicity and geodetic deformation. Shallowdepth seismicity and deformation of the dome at Mount St. Helens increased beyond background level on March 22. The rate of deformation increased more than twenty-fold, from about $12 \mathrm{~mm}$ per day to more than $30 \mathrm{~cm}$ per day, between March 22 and March 27, (P.M. Otway, New Zealand Geological Survey, written commun., 1984). By March 27, earthquakes that could be felt and heard occurred frequently within the crater. Geodetic measurements indicated the northern part of the dome was spreading most rapidly in response to the intrusion of new magma. The rapid rate of deformation and extensive cracking of the north flank of the dome caused concern that a small explosion and (or) rock avalanche might occur, which in turn could generate flood surges or lahars that could affect downstream areas.

On March 29 a segment of the north flank of the dome failed and disaggregated into a rock avalanche that covered about $2 \times 10^{5} \mathrm{~m}^{2}$ of the crater floor. Subsequent rock avalanches from exposed hot rock and rockfalls from the spalling carapace of the dome and from newly extruded lava (first observed on March 30) added to the deposit of debris during the next several days (fig. 5.2). No explosion, significant snowmelt, or flood occurred, however.

This chapter describes the complex deposit that resulted from the rock avalanches and rockfalls of March 29, 1984, deduces the geologic processes that produced various components of that aggregate deposit, and suggests why a flood was not generated. The events described in this chapter contrast a winter-condition eruption having only a local effect to other wintercondition eruptions that had far-reaching effects downstream (for example, Waitt and others, 1983; Pierson and Scott; 1985; Pierson, chap. 2, this volume; Pierson and Waitt, chap. 4, this volume; Pringle and Cameron, chap. 6 , this volume). Since the emplacement of the rock avalanches and rockfalls of March 1984, other similar events have occurred and their deposits have buried the deposits described in this chapter.

\section{TERMINOLOGY}

The term rock avalanche is applied somewhat broadly in this chapter. Some masses of failed material probably were initiated by sliding, others by falling. However, most of the failed rock masses quickly disaggregated into predominantly sand-sized particles, and the resulting deposits have characteristics of flow. The term avalanche connotes flow behavior. Initiation of an avalanche by slide or fall does not significantly affect the characteristics of the resulting deposit (McSaveney, 1978). Rockfall refers to rock masses that became dislodged, remained essentially intact or disaggregated into predominantly boulder-sized fragments, and contributed primarily to a deposit of bouldery talus that does not have characteristics of flow. Pyroclastic flow refers to a hot, rapidly moving, high-concentration dispersion of gas and solid particles that commonly flows in a nonturbulent manner. Pyroclastic-flow deposits commonly are characterized by massive diamicts that can 


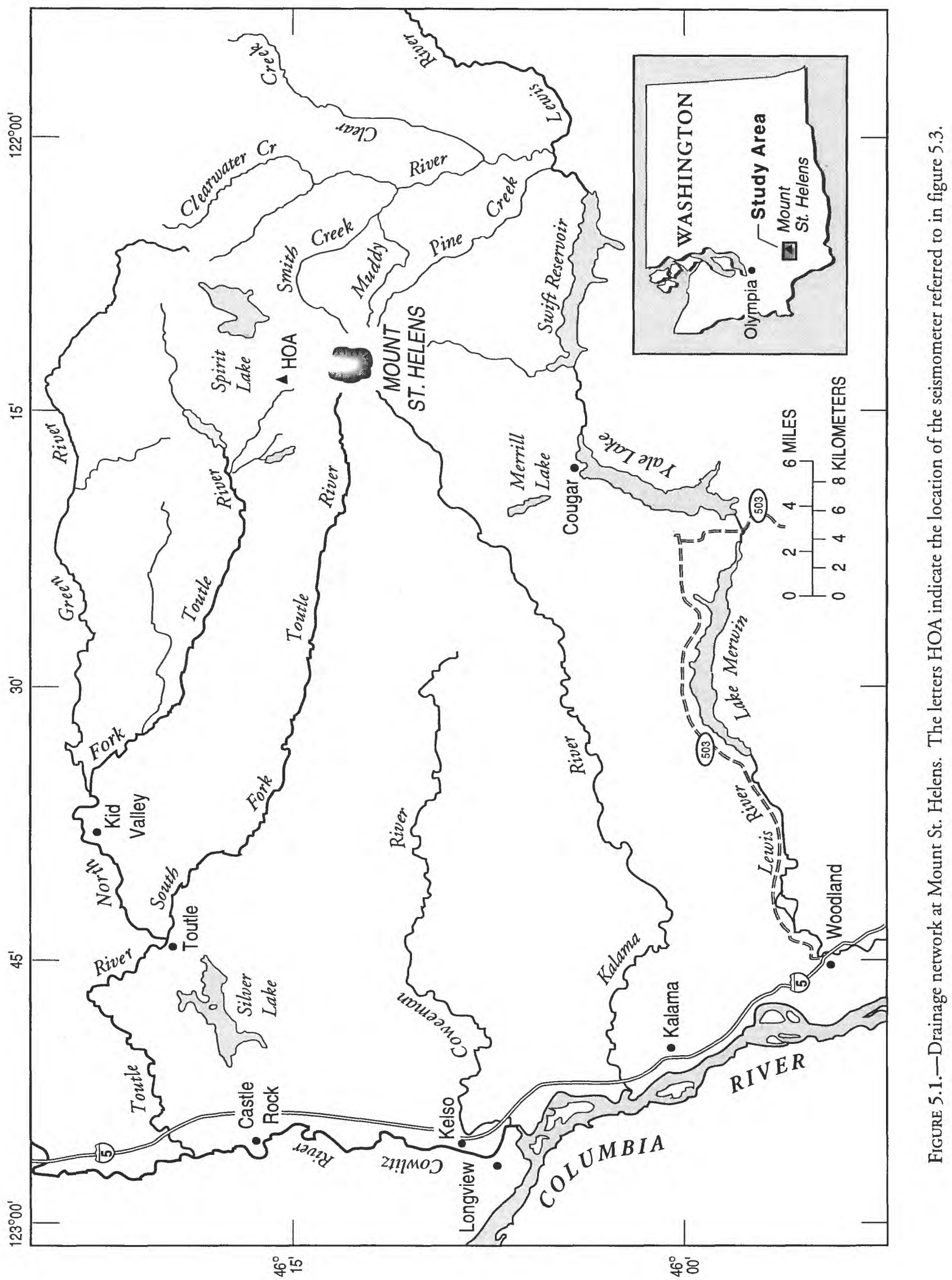


exhibit vertical variation in the distribution of coarse particles (Carey, 1991). A continuous spectrum of transport and depositional mechanisms exists between hot-rock avalanches and pyroclastic flows. Pyroclastic surge refers to a hot, low-concentration dispersion of gas and solid particles that flows in a turbulent manner, and whose deposit is commonly thinly to thickly laminated and has planar to cross stratification (Fisher and Schminke, 1984; Carey, 1991).

\section{TIMING OF ROCK AVALANCHES AND ROCKFALLS}

At approximately 0319 Pacific Standard Time (PST) on March 29, 1984, the U.S. Weather Service radar at Portland, Oregon, recorded a plume to an altitude of
$4.6 \mathrm{~km}$ over the crater of Mount St. Helens. Simultaneously, seismograph signals received at the U.S. Geological Survey in Vancouver, Washington, suggested that a series of rock avalanches or rockfalls had occurred. As inferred later from the seismic signals, the first rock avalanche occurred shortly after 0318 , and during the next several minutes was followed by several similar events that produced avalanche-like seismic signals (fig. 5.3).

A pre-dawn reconnaissance flight on March 29, 1984, verified the presence of a rock-avalanche deposit north of the dome. During the flight, several incandescent rockfalls were observed moving down the north face of the dome. Photographs taken during a later flight at 1030 indicated the rock-avalanche deposit resulted from emplacement of multiple avalanches, an observation consistent with the inferences drawn from the seismic signals. During the next several days lava extruded and

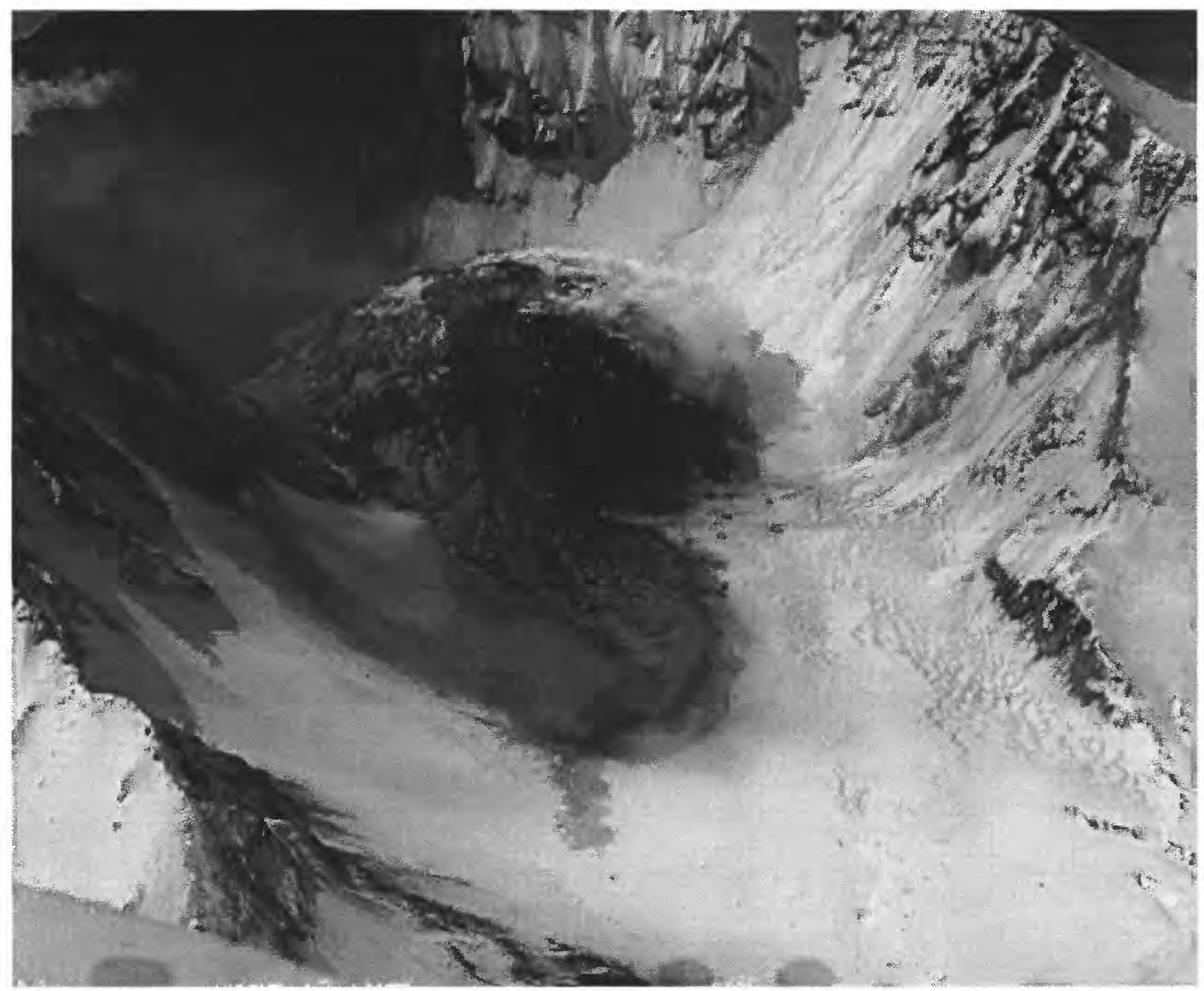

Figure 5.2.-Oblique aerial view of Mount St. Helens crater showing lava dome and March 29, 1984, rock-avalanche fan. View is south-southwest. Lava dome is about 1000 meters in diameter. 
spread across the top of the dome. When the lava reached the steep north flank of the dome, it spalled and produced rockfalls that moved down the north face of the dome and deposited bouldery talus on the rock-avalanche deposits. Rockfalls from this lava lobe persisted for several days. Many incandescent rockfalls visible beyond the crater were recorded on March 31 in a dramatic timelapse photograph taken from a U.S. Army Corps of Engineers pump station located near the outlet of Spirit Lake (fig. 5.4).

\section{DEPOSITS OF THE ROCK AVALANCHE-ROCKFALL COMPLEX}

The deposits that resulted from the initial rock avalanches and later rockfalls of March 29, 1984, formed a crudely oval fan about $700 \mathrm{~m}$ long and $500 \mathrm{~m}$ wide (figs. 5.5 and 5.6). Preliminary observations of the deposits were made by aerial reconnaissance on the morning of March 29; the weather was clear, the deposits were fresh, and physical features of the fan were easily recognized. The fan appeared to be bordered by two distinctly concentric zones: a dark-colored inner zone, and a light-colored outer zone that graded into a deposit plastered on the east crater wall (figs. 5.2 and 5.5). Inclement weather prevented ground investigation of the deposits until April 2. By then, several inches of new snow had fallen and covered all but the central area of the fan, which apparently remained warm.

\section{UNIT A}

A brief examination of deposit stratigraphy and morphology indicated the fan consisted primarily of five depositional Units. The basal deposit, Unit A, was a compact, dark-brown diamict that covered an area of about $2 \times 10^{5} \mathrm{~m}^{2}$. It was composed of a thin (less than 2 $\mathrm{cm}$ thick) basal layer of discontinuous, commonly frozen, silty, fine sand that contained scattered coarse sand to granules. The basal layer was overlain gradationally by 2 to $7 \mathrm{~cm}$ of nonstratified silty sand that contained 5 to 10 percent lithic granules. This nonstratified sandy layer was in turn overlain in gradational-to-sharp contact by 20 to $30 \mathrm{~cm}$ of poorly sorted, pebbly, silty sand that was inversely graded locally and supported clasts as large as $20 \mathrm{~cm}$.

The basal facies lay in sharp contact with the underlying snow surface. Near the deposit margin, the contact was locally erosional (fig. 5.7). Where exposed the deposit was 30 to $40 \mathrm{~cm}$ thick, and subjacent snow appeared to be eroded at least $20 \mathrm{~cm}$ deep (see Walder, chap. 1, this volume). However, the contact with underlying snow dipped mostly toward the center of the fan; therefore, the maximum thickness of the deposit occurred near the central part of the fan. If the deposit thickness along the margin is used as an average value for the whole deposit, then an estimated minimum volume for unit $A$ is $8 \times 10^{4} \mathrm{~m}^{3}$.

A layer of granular ice 1 to $2 \mathrm{~cm}$ thick mantled the top of the snow surface beneath unit $A$ at the distal margin of the deposit. A similar, but thinner, layer of granular ice also mantled the snow beyond the area affected by the rock-avalanche deposit. The difference in thickness between the ice layer beneath and beyond the avalanche deposit may be evidence for minor melting of snow during emplacement of unit $A$, caused perhaps by friction between the snow and the overriding debris, or perhaps by warm rock that was incorporated in the rock avalanche. Warm rock could have come from fumaroles

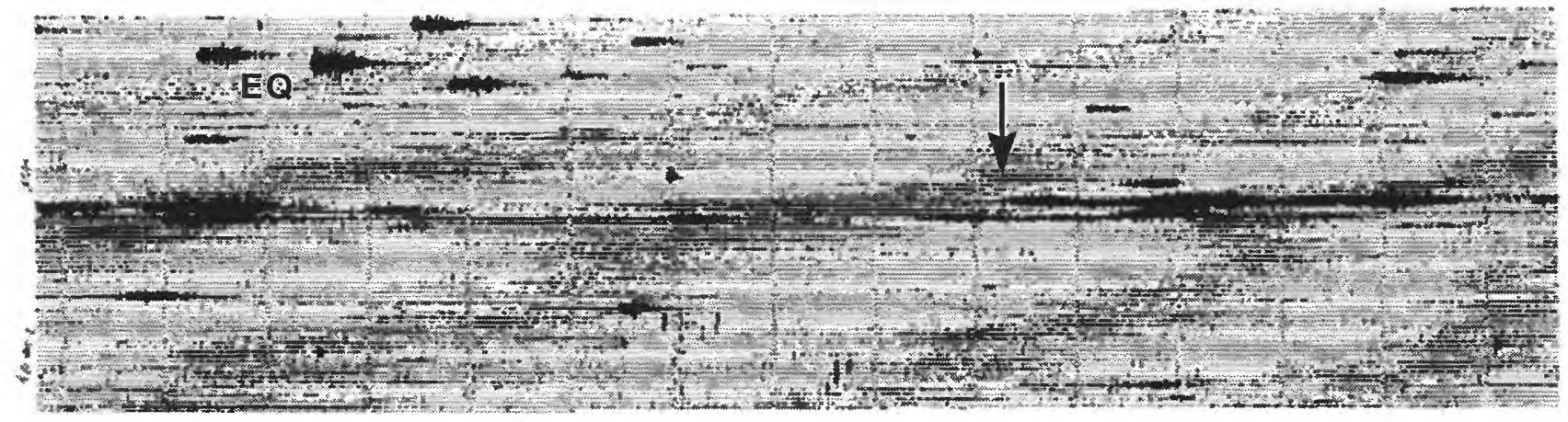

Figure 5.3.- Seismograph record of March 29, 1984, from seismic station HOA. The first significant rock-avalanche signal occurred about 0318 Pacific Standard Time (arrow) and was followed closely by similar signals during the next several minutes. Note the difference between short earthquake signals (EQ) and long rock-avalanche signals. 
on the north side of the dome or from segments of the recently extruded February 1984, lava lobe that were incorporated in the initial failure.

The poorly sorted nature of unit A, local inverse grading, and basal erosion indicate that this unit formed by a flow process. We therefore conclude that unit $\mathrm{A}$ resulted from a rock avalanche and not simply from a rockfall. The wet, compact nature of the deposit, the absence of significant melting of snow, and the absence of evidence for hot emplacement suggest that unit $A$ formed from a source of relatively cool material and was emplaced at low temperature.

\section{UNITS B1 AND B2}

Overlying unit $A$, in sharp contact, was a rockavalanche deposit consisting of dry, loose, lithic-rich sand in which pebble- to boulder-sized clasts were dispersed (unit B1). The upper several centimeters of this loose sand commonly was damp (fig. 5.8). Several of the large boulders in the middle and distal reaches of the fan, some many meters in diameter, probably were transported by this rock avalanche.

The surface morphology of unit B1 contrasted markedly with that of unit A. Several small pits as wide as 1 to $2 \mathrm{~m}$ were evident locally on the surface (figs. 5.5; 5.6). These pits were the result of either small phreatic (steam) explosions caused by hot particles interacting with snow or collapse around hot rocks that melted downward into underlying snow. The pits did not result from ballistic impacts, for if they had, pits also would have been present in the snow beyond the deposit, which they were not. Even though new snow had fallen subsequent to the emplacement of the rock-avalanche deposits, impact pits in the original snow surface would have been obvious. In addition to pits, the surface of

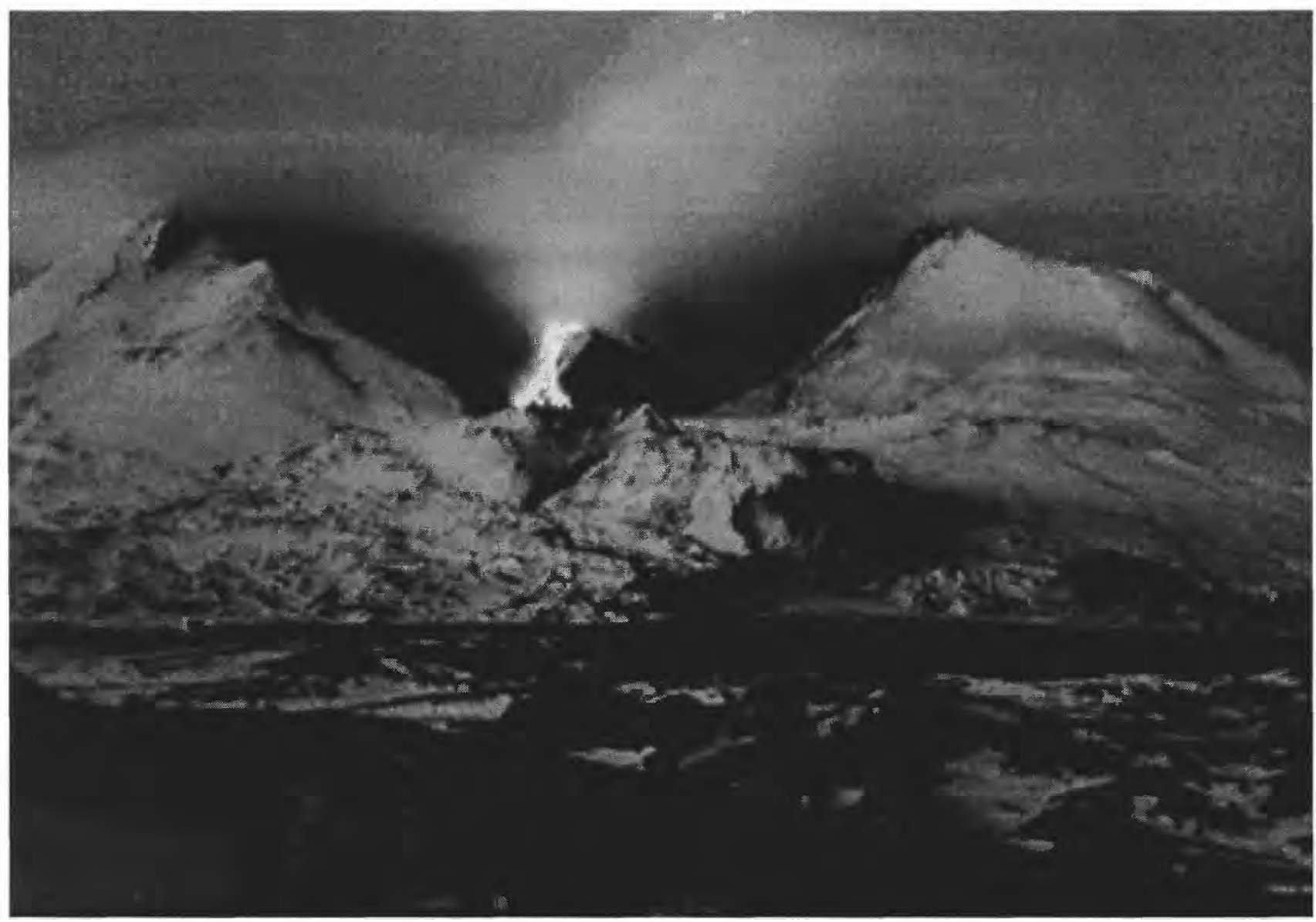

Figure 5.4.-Time-lapse photograph of incandescent rockfalls on March 31, 1984, resulting from spalling of newly extruded lava. Lava dome is about 350 meters high. Photograph taken from U.S. Army Corps of Engineers pump station near Spirit Lake, 8 kilometers north-northeast of crater. Copyrighted photograph by Jack Hash; published with permission. 
unit B1 was studded with clasts averaging about $0.5 \mathrm{~m}$ in diameter. The unit also consisted locally of lobate deposits from smaller rock avalanches, indicating that this unit resulted from emplacement of multiple pulses rock avalanche. Individual lobes as thick as 2 to $3 \mathrm{~m}$ contained meter-sized clasts.

In several localities, pockets of debris had temperatures greater than $50^{\circ} \mathrm{C}$ (the thermometer limit) on April 2. Owing to the loose, dry texture of the deposit, the pockets of hot debris, and the pits that probably originated by small phreatic explosions or collapse, we conclude that unit B1 was hot when it was deposited.

Unit B1 covered an area much smaller than did unit A (about $1 \times 10^{5} \mathrm{~m}^{2}$ ); most of unit B1 was deposited near the base of the dome (fig. 5.6). Volume estimates of unit B1 are not well constrained because estimates of the thickness of the deposit are poor. A volume estimate for unit B1 of $3 \times 10^{5} \mathrm{~m}^{3}$ of debris is based on an assumed average thickness of about $3 \mathrm{~m}$.

Emplacement of a third phase of rock avalanches (unit B2) was interpreted primarily from aerial photographs of the debris fan. The loose, dry, sand-rich deposits resulting from the rock avalanches that produced unit B2 were similar to those of unit B1. The rock avalanches that formed unit B2 eroded into deposits along the margin of the debris fan and melted into the snow substantially below the pre-fan surface. As a result, unit B2 deposits overlie, and were inset against, older deposits. Along the east margin of the fan debris from unit B2 was deposited in a cove about $2.5 \mathrm{~m}$ below the surrounding surface. Exposure in the walls of the cove showed that unit A rested on a grooved snow surface and was partly eroded by unit B2. During emplacement, avalanches that deposited unit B2 apparently scoured enough debris from unit $A$ that they were able to transfer sufficient heat to melt down through about $2 \mathrm{~m}$ of snow. Deposits of unit B2 spread across an area of about $4 \mathrm{x}$ $10^{4} \mathrm{~m}^{2}$. An estimated volume of $1 \times 10^{5} \mathrm{~m}^{3}$ for unit B2 is based on an assumed average deposit thickness of $3 \mathrm{~m}$.

\section{UNIT C}

The dry, loose, sandy deposits of units B1 and B2 were overlain sharply by a few centimeters of massive,

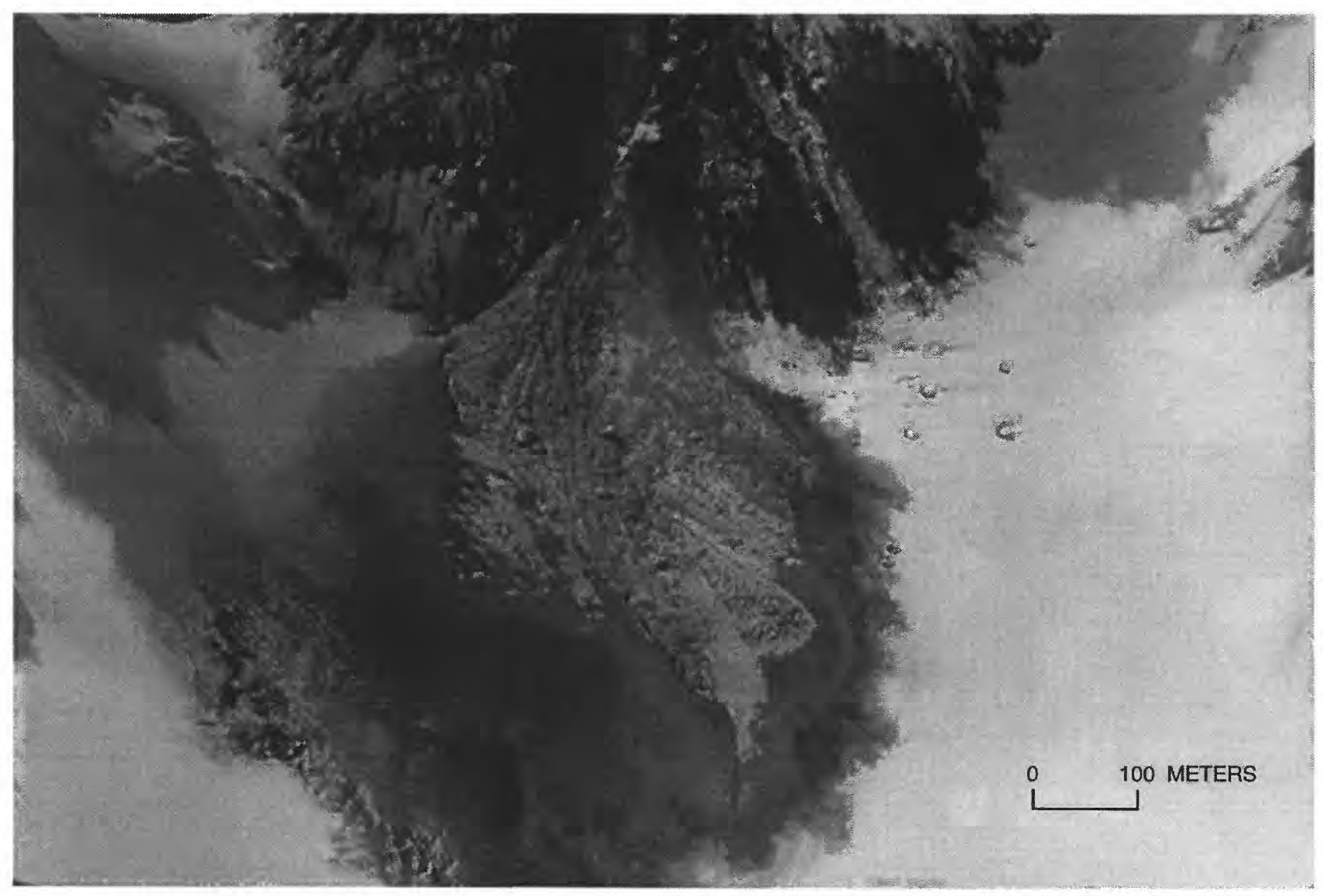

FIGURE 5.5.-Oblique southward aerial view of March 29, 1984, rock-avalanche fan. 
silty, fine sand that contained scattered granules to a few $\mathrm{mm}$ in diameter (unit C; fig. 5.8). Similar massive, silty sand, probably contiguous with the sand overlying units B1 and B2, constitutes part of the boundary deposits discussed below. The massive, silty sand generally did not mantle the large boulders near the head of the debris fan (see unit D).

The lack of seismic signals that indicate any geomorphic processes other than rock avalanches and rockfalls during the events described in this chapter (such as explosions from the dome), the mantle of silty sand on units B1 and B2, and the general lack of a sand deposit on the many boulders that compose unit $\mathrm{D}$ indicate a close association between the hot-rock avalanches that deposited units B1 and B2 and the geologic process that deposited unit $C$. The generally massive texture of the silty sand indicates that it was deposited by a relatively high-concentration flow and not by a low-concentration surge. We attribute unit $C$ to emplacement by an areally restricted pyroclastic flow associated with the complete disaggregation of rock involved in the hot-rock avalanches that deposited units B1 and B2.

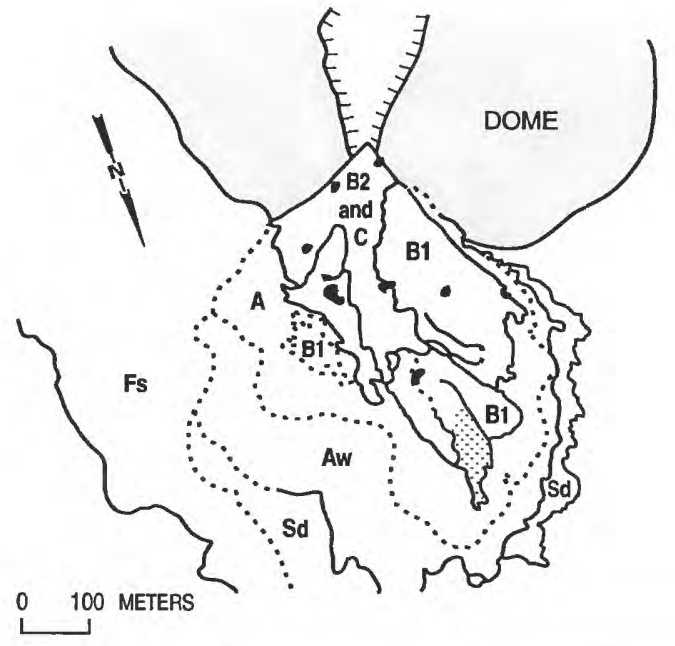

\section{EXPLANATION}

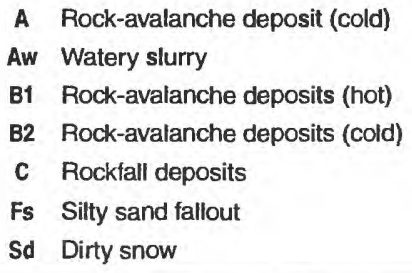

A Rock-avalanche deposit (cold)

Aw Watery slurry

B1 Rock-avalanche deposits (hot)

B2 Rock-avalanche deposits (cold)

C Rockfall deposits

Fs Silty sand fallout

Sd Dirty snow

Figure 5.6.-Geologic map of rock avalanche-rockfall complex compiled from figure 5.5.

\section{UNIT D}

Rockfall deposits that consist of boulders several meters in diameter, unit $\mathrm{D}$, formed a talus apron near the head of the debris fan (fig. 5.6). This apron of talus resulted from persistent rockfall activity during the several days that followed the rock avalanches on March 29. We did not estimate the volume of this bouldery talus

\section{BOUNDARY DEPOSITS}

A deposit consisting of a dark-colored inner zone and a light-colored outer zone bounded the rock-avalanche fan. The dark inner zone consisted of about $1 \mathrm{~mm}$ of frozen silt overlain by 1 to $2 \mathrm{~cm}$ of massive, fine to medium sand that contained scattered granules. The sand, in turn, was overlain locally by a few centimeters of graded, silty fine sand. Except for the surficial silty sand, the dark deposit has two possible origins: (1) a dilute slurry facies related to unit $A$, or (2) a facies of pyroclastic flow related to disaggregation of the hot-rock avalanches (units B1 and B2). The light-colored outer zone consisted of dirty snow, caused by muddy water seeping through the snowpack, and of a mantle of massive to moderately graded silty sand overlying the snow. The mantle of silty sand, similar to the sand that caps much of the debris fan, is attributed to a small pyroclastic flow, and perhaps an associated surge-like cloud, and to fallout dust generated by fragmentation of the rock avalanches, particularly the hot-rock avalanches that produced units B1 and B2. Fallout dust coated the east crater wall. The plume detected by the National Weather Service radar during the early phase of the events was composed of ash convecting from the rock avalanches and the associated pyroclastic flow, and not from an explosion. Fallout of very fine ash was reported as far as $70 \mathrm{~km}$ south-southwest of Mount St. Helens (Bobbie Myers, U.S. Geological Survey, oral commun., 1984).

\section{CAUSES OF ROCK AVALANCHES AND ROCKFALLS}

The initial rock avalanche on March 29 was the culmination of intense fracturing and weakening of the north side of the dome, which resulted from lateral spreading induced by the intrusion of new magma. On March 22, the rate at which the dome deformed increased beyond background level. By March 27, the north side of the dome deformed at an average rate greater than 


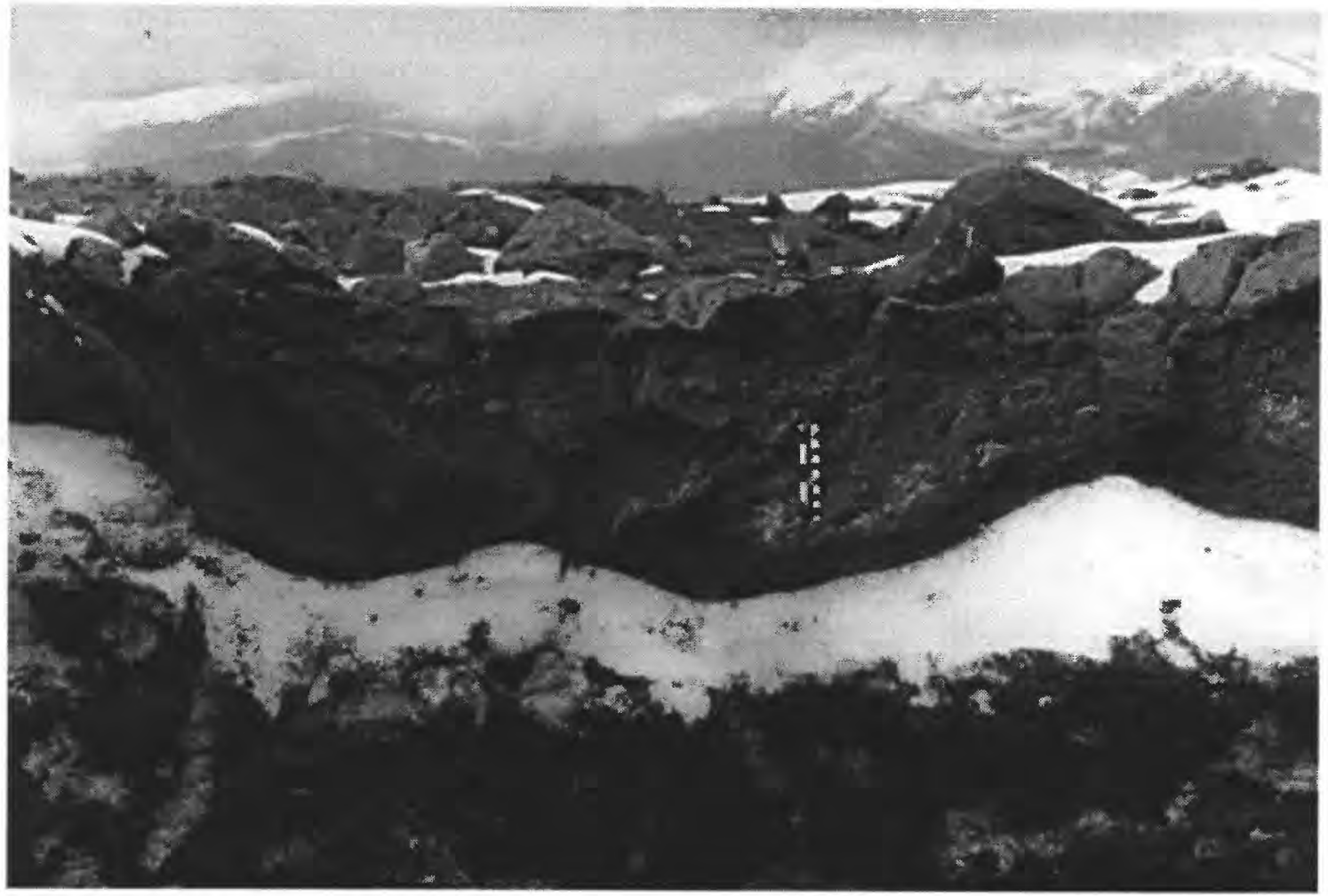

FigurE 5.7.-Undulating surface of snow at the base of unit A. View looking northward in direction of flow. Scale divisions in centimeters (right) and inches (left).

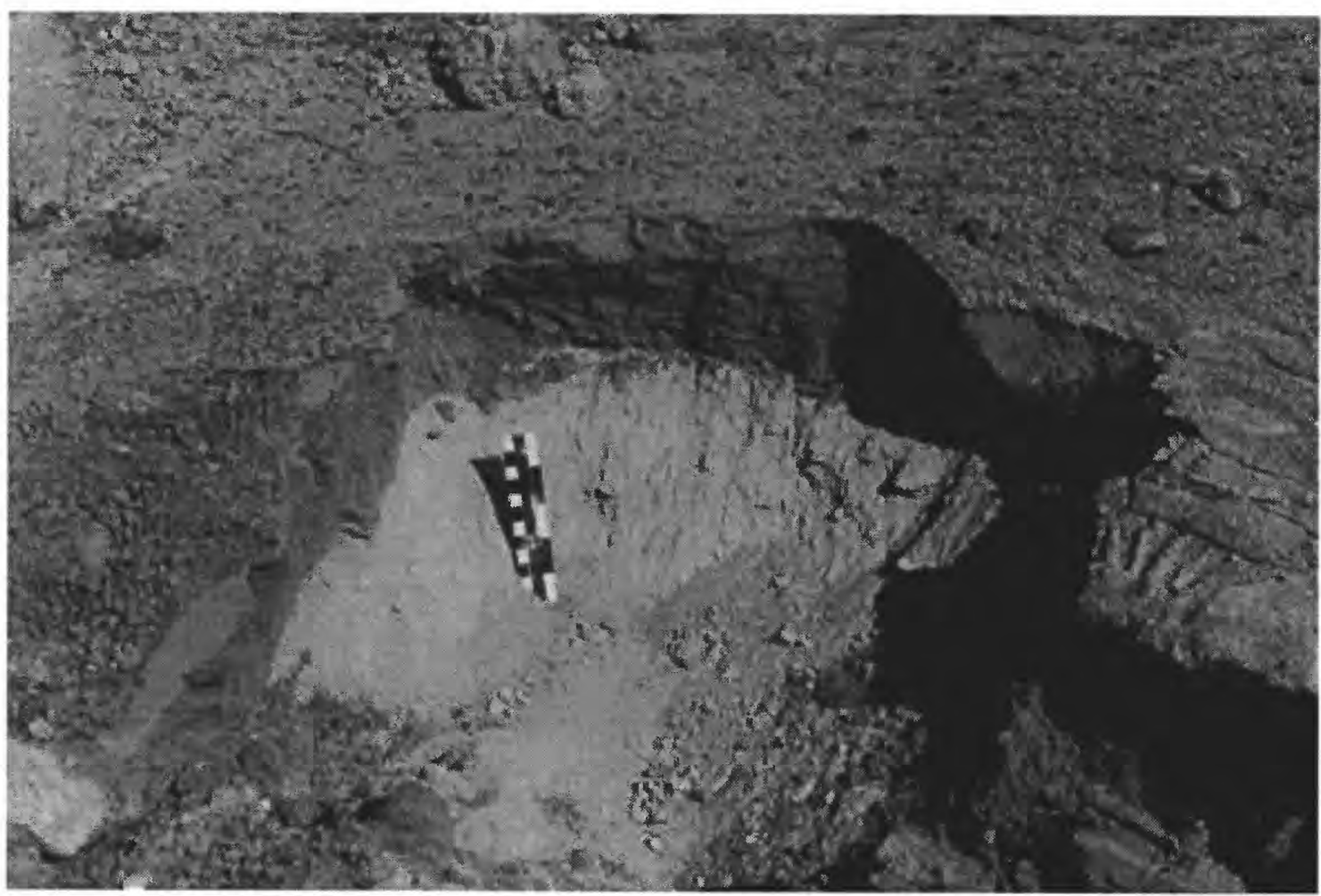

Figure 5.8. - Exposure of unit B1 illustrating the poorly sorted, loose, dry texture of the deposit. The upper several centimeters of unit B1 is damp, and the unit is overlain by about 2 centimeters of fine silty sand (unit C) deposited by a pyroclastic flow associated with the avalanche. Scale divisions in centimeters (left) and inches (right). 
$30 \mathrm{~cm}$ per day, whereas the west and south sides of the dome deformed at rates of 8 and $2 \mathrm{~cm}$ per day (P.M. Otway, New Zealand Geological Survey, written commun., 1984). Reflectors mounted on the dome were displaced northward by $42 \mathrm{~m}$ between midday on March 27, and midday on March 29; total displacement of the north sector of the dome during this eruption was estimated at $57 \mathrm{~m}$. Intrusion of new magma into the dome thus severely disrupted, and mechanically weakened, the northern sector of the lava dome in the few days prior to the rock avalanches. By 1700 on March 27, a new arcuate crack, 1 to 2 meters wide and about 10 meters deep, appeared on the north-northwest sector of the February 1984 lava lobe, which had been extruded high on the northeast part of the dome (Daniel Dzurisin, U.S. Geological Survey, written commun., 1984). At about 0318 on March 29 segments of the north side of the dome and of the February lobe failed. The geometry of the north flank of the dome before and after the March rock avalanches, based on profiles measured from contour maps from January 31, 1984, and April 14, 1984, is illustrated in figure 5.9. Disruption of the dome and emplacement of extruded lava in February 1984 precluded direct measurement of the initial volume of failed rock and of the total thickness of the March rock-avalanche deposits, but the failure plane, transport slope, and the region of deposition are clearly indicated by the profiles.

On the basis of the stratigraphy and morphology of the deposits and on the recorded seismic signals, we offer the following interpretation of the events of March 29. Segments of the outer shell of the dome dislodged, and rapidly disaggregated, after the north flank was severely weakened by intruding magma. The disaggregated mass flowed down the north face of the dome, incorporated snow and possibly saturated debris from the talus apron, and then spread out to become unit A of the rockavalanche fan. That large segments of rock from lava domes can fail, disaggregate almost instantaneously, and transform into flowing masses has been observed at Mount St. Helens (N.S. MacLeod, U.S. Geological Survey, oral commun., 1985) and at Unzen volcano, Japan (Ishikawa and others, 1992). Removal of a part of the outer shell destabilized other mechanically weakened segments of the dome high on the north side and induced retrogressive failure. The ensuing piecemeal failure (indicated by development of diamict stratigraphy in unit A) consequently exposed hot rock in the dome. Continued retrogressive failure of hot rock produced pulses of hot-rock avalanches closely associated in time with the initial cold rock avalanche, and resulted in units B1 and B2. As these hot-rock avalanches disaggregated, they generated a small pyroclastic flow (or flows) that swept over the avalanche debris and deposited a mantle of massive, silty sand (unit $\mathrm{C}$ ). When magma reached the surface of the dome, small rockfalls, involving older pieces of the dome as well as new debris, continued intermittently for several days and produced unit $\mathrm{D}$.

Processes similar to those described in this chapter occurred during a hot-rock avalanche in May 1986 (Mellors and others, 1988). That avalanche produced a fan-shaped deposit that consisted of coarse, bouldery, juvenile debris, more extensive pyroclastic-flow and pyroclastic-surge deposits, and fine-grained tephra that fell several kilometers downwind. As with the March 1984 episode of rock avalanches, no explosion occurred and all of the observed facies resulted from the disaggregation of rock during the emplacement of the avalanche.

There are two major differences between the March 1984 and May 1986 events, however. During the rock avalanches of May 1986, hot debris mixed with snow and produced debris flows in the crater and a small flood and debris flow that left the crater (Cameron and Pringle, 1990). Also, no deposit corresponding to an avalanche of cold rock was recognized from the May 1986 event. The May 1986 event was caused primarily by the failure of a segment of rock from a new lava lobe and not by the failure of rock from the older, colder carapace of the dome.

At volcanoes where lava domes have been extruded onto slopes much steeper than the floor of the Mount St. Helens crater, gravitational collapse of segments of the domes has occurred without precursory activity or warning and has generated hot-rock avalanches and

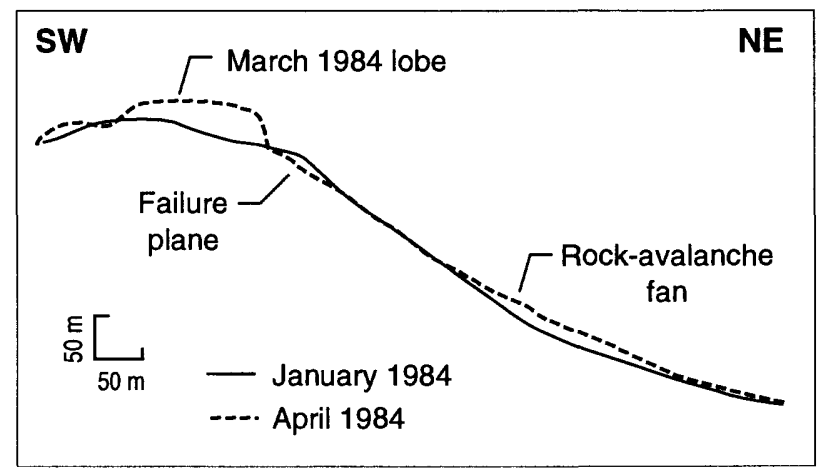

Figure 5.9. - Profiles of the north part of the Mount St. Helens dome on January 31, 1984, and April 14, 1984. 
pyroclastic flows that have traveled far beyond the lava dome, sometimes with tragic consequences. Hot-rock avalanches, pyroclastic flows, and pyroclastic surges occurred during the 1990 eruptions of Redoubt volcano, Alaska, when disrupted, thermally stressed rock from the lava dome suddenly failed and rapidly disaggregated (Miller, 1994; Gardner and others, 1994). Pyroclastic flows that resulted in 43 deaths occurred when the lava dome at Unzen volcano, Japan, suddenly collapsed and hot rock disaggregated explosively (Fink, 1991; Ishikawa and others, 1992). Similar dome collapses and associated pyroclastic flows also have occurred during past eruptions of Mount Hood volcano, Oregon (Brantley and Scott, 1993).

\section{IMPLICATIONS FOR FUTURE MASS FAILURES}

Rock avalanches and rockfalls have occurred infrequently from the lava dome at Mount St. Helens during periods of eruption and of quiescence. If episodic growth of the lava dome persists during the next several decades, new lava lobes probably will be extruded, and growth by intrusion of magma will certainly recur. Regardless of how growth proceeds, rock avalanches and rockfalls should occasionally occur owing to deformation and lateral spreading of parts of the dome. Rock avalanches such as those described in this chapter may be a visible external expression of future volcanic activity. However, rock avalanches of the magnitude described in this chapter are likely to affect only the crater.

Comparison of the March 1984 rock avalanches with other similar events at Mount St. Helens, particularly the May 1986 event, suggests that the deposit from the initial, cold rock avalanche prevented the subsequent hotrock avalanches and rockfalls from mixing with snow and generating debris flows and floods. Although the hot-rock avalanches of March 1984 probably were similar in temperature to those of May 1986, the March 1984 rock avalanches did not generate pyroclastic flows that extended far beyond the limits of the cold avalanche. Thus there was little, if any, opportunity for quantities of hot debris to mix with snow.

Although small rock avalanches and rockfalls from the dome usually are not vigorous enough or hot enough to melt snow rapidly and cause flooding beyond the crater, exceptions do occur (Mellors and others, 1988; Pringle and Cameron, chap. 6, this volume). Most of the volcanic events that affected areas beyond the crater were accompanied by small explosions of hot gas and rocks (Waitt and others, 1983; Brantley and others, 1985; Pierson, chap. 2, this volume; Pierson and Waitt, chap. 4, this volume). During those events, snow from the crater walls and floor melted suddenly and produced varied combinations of flood surge, slushflow, and mixed avalanches of snow and debris that flowed out of the crater. Such flows commonly incorporated sediment as they moved across the steep slopes beyond the crater, and some of the flows subsequently transformed into lahars that traveled tens of kilometers downstream (Waitt and others, 1983; Pierson and Scott, 1985). Without a snowpack, the likelihood of rock avalanches similar to those described in this chapter spawning flows that would affect areas beyond the crater is vastly decreased. Potential hot-rock avalanches and related pyroclastic flows and surges precipitated by a substantially larger failure of the dome, however, could pose a future hazard beyond the crater regardless of snowpack conditions.

\section{CONCLUSIONS}

Rapid spreading and extensive cracking of the lava dome at Mount St. Helens related to intrusion of new magma in March 1984, generated a series of small rock avalanches. The total volume of deposited debris was about $5 \times 10^{5} \mathrm{~m}^{3}$. The initial rock avalanche probably was cold, and its deposit consisted of a thin, dense diamict. Subsequent rock avalanches had their source in hot material. When the hot rock failed it rapidly disaggregated into dominantly sand-sized particles and generated not only hot-rock avalanches but also a small pyroclastic flow(s). The hot debris was unable to mix with snow, however, owing to the underlying avalanche deposit.

Snow provides an abundant water source that can exacerbate the lahar hazard down valley if hot-rock avalanches and associated processes cause rapid melting. But more energetic, much hotter, or much larger rock avalanches than those of March 1984 are needed to produce associated meltwater flows that would affect areas beyond the crater. Without a snowpack, rock avalanches must be substantially larger than those of March 1984 to pose a threat beyond the crater. 


\section{ACKNOWLEDGMENTS}

We thank our USGS colleagues for discussions and reviews of earlier drafts of this paper, and Muriel Hash for allowing us to publish figure 5.4.

\section{REFERENCES CITED}

Brantley, S.R., Power, J.A., and Topinka, L.J., 1985, Reports from the U.S. Geological Survey's Cascades Volcano Observatory at Vancouver, Washington: U.S. Geological Survey Earthquake Information Bulletin, v. 17, no. 1, p. 20-32.

Brantley, S.R., and Scott, W.E., 1993, The danger of collapsing lava domes: Lessons for Mount Hood, Oregon: U.S. Geological Survey Earthquakes and Volcanoes Information Bulletin, v. 24, no. 6, p. 244-269.

Cameron, K.A., and Pringle, P.T., 1990, Avalanche-generated debris flow of 9 May 1986 at Mount St. Helens, Washington: Northwest Science, v. 64, no. 3, p. 159-164.

Carey, S.N., 1991, Transport and deposition of tephra by pyroclastic flows and surges, in Fisher, R.V., and Smith, G.A., eds., Sedimentation in volcanic settings: SEPM (Society for Sedimentary Geology), Special Publication no. 45, p. 39-57.

Fink, J.H., 1991, Volcano warning needed: Nature, v. 351, no. 6328, p. 611.

Fisher, R.V., and Schminke, H.-U., 1984, Pyroclastic rocks: Springer-Verlag, Berlin, $472 \mathrm{p}$.

Gardner, C.A., Neal, C.A., Waitt, R.B., and Janda, R.J., 1994, Proximal pyroclastic deposits from 1989-90 eruption of Redoubt Volcano, Alaska-stratigraphy, distribution, and physical characteristics: Journal of Volcanology and Geothermal Research, v. 62, p. 213-250.
Ishikawa, Yoshiharu, Yamada, Takashi, and Yajima, Shigemi, 1992, A study on the pyroclastic flows and debris flows associated with the Mount Unzen eruption in 1991: Sabo Department, Public Works Research Institute, Ministry of Construction (Japan), PWRI Technical Memorandum no. $3141,56 \mathrm{p}$.

McSaveney, M.J., 1978, Sherman glacier rock avalanche, Alaska, U.S.A., in Voight, Barry, ed., Rockslides and avalanches-1. Natural phenomena in the collection developments in geotechnical engineering: Amsterdam, Elsevier, v. 14A, p. 197-258.

Mellors, R.A., Waitt, R.B., and Swanson, D.A., 1988, Generation of pyroclastic flows and surges by hot-rock avalanches from the dome of Mount St. Helens volcano, USA: Bulletin of Volcanology, v. 50, no. 1, p. 14-25.

Miller, T.P., 1994, Dome growth and destruction during the 1989-90 eruption of Redoubt Volcano: Journal of Volcanology and Geothermal Research, v. 62, p. 197-212.

Pierson, T.C., and Janda, R.J., 1994, Volcanic mixed avalanches: A distinct eruption-triggered mass-flow process at snow-clad volcanoes: Geological Society of America Bulletin, v. 106, p. 1351-1358.

Pierson, T.C., and Scott, K.M., 1985, Downstream dilution of a lahar; transition from debris flow to hyperconcentrated streamflow: Water Resources Research, v. 21, no. 10, p. 1511-1524.

Waitt, R.B., Jr., Pierson, T.C., MacLeod, N.S., Janda, R.J., Voight, Barry, and Holcomb, R.T., 1983, Eruptiontriggered avalanche, flood, and lahar at Mount St. Helens-Effects of winter snowpack: Science, v. 221, no. 4618 , p. $1394-1397$. 


\title{
ERUPTION-TRIGGERED LAHAR ON MAY 14, 1984
}

\author{
By Patrick T. Pringle ${ }^{1}$ and Kenneth A. Cameron ${ }^{2}$
}

\begin{abstract}
CONTENTS

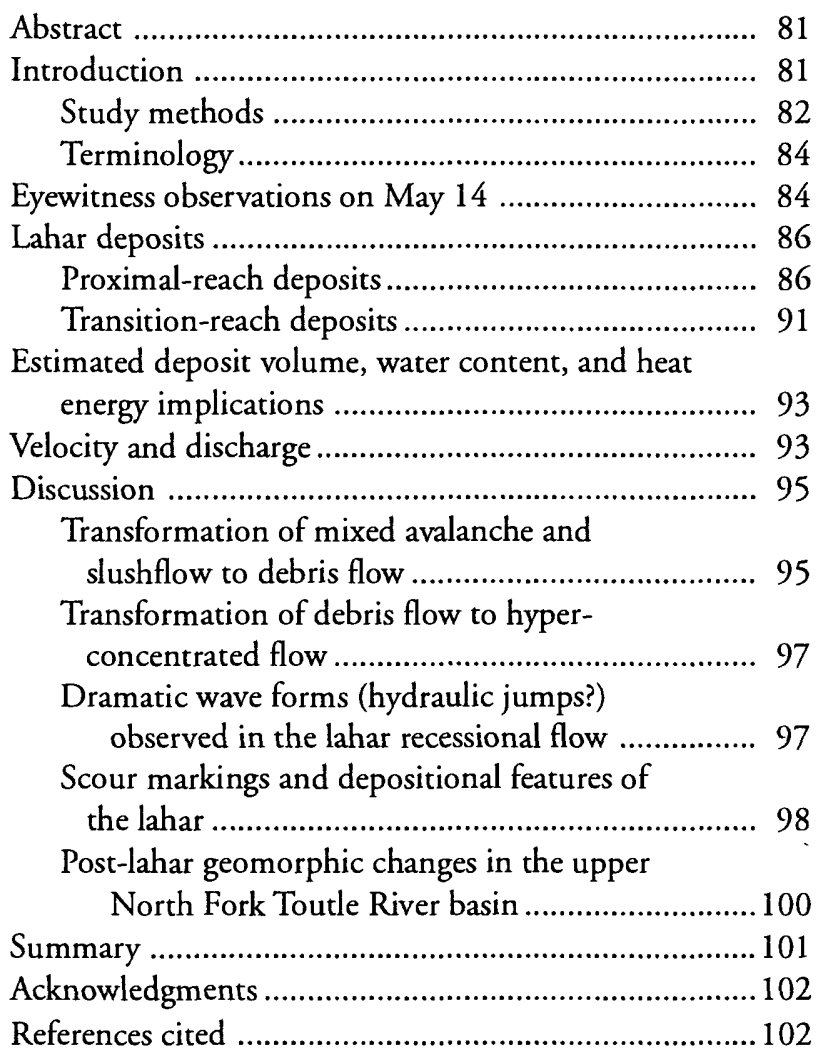

\section{ABSTRACT}

On May 14, 1984, a shallow-seated explosion from the dome at Mount St. Helens sprayed the west crater wall with hot rock debris and gases and triggered a mixed snow-androck avalanche and slushflow that exited the crater through the Breach into upper Loowit Ravine. This mixture transformed into a debris flow on the Pumice Plain as it accumulated sediment and heat from the still-hot 1980 pyroclastic flow deposits and added water through melting of admixed snow and ice granules and through incorporation of water from stream channels and saturated sediments. The resulting debris flow was erosional throughout the Pumice Plain but caused aggradation of the active channel of the North Fork Toutle River from 8 to 16 kilometers from the lava dome before transforming to a hyperconcentrated flow. Temporal and downstream changes in the flow behavior and correlative textural changes in deposits were documented by eyewitness observations, velocity measurements, sampling of the lahar, and examination of deposits after they became exposed. At least $7.1 \times 10^{10}$ joules was required to generate the estimated $4 \times 10^{5}$ cubic meters of meltwater incorporated in the lahar from crater snow and ice.

\section{INTRODUCTION}

This report documents an unusual geologic opportunity, that of making eyewitness observations of a small lahar at close range and then subsequently examining the deposits and geomorphic effects of the lahar. This may be the first report that describes how visually observed flow transformations in a lahar have been correlated with downstream textural changes in its deposits.

A shallow-seated volcanic explosion from the upperwest flank of the Mount St. Helens lava dome triggered a lahar on May 14, 1984, just after 0937. A mixed snowand-rock avalanche from the west crater wall and a recessional slushflow moved northeastward, exited the 1980 crater through the Breach, and then entered Loowit Ravine, incising the surface of the crater floor and upper Steps as deep as $2 \mathrm{~m}$ along a 30 -m-wide track (fig. 6.1). This mixture splayed into three distributary lobes on Step Fan at the mouth of Loowit Ravine, about $5 \mathrm{~km}$ from the lava dome (fig. 6.2).

\footnotetext{
${ }^{1}$ Current address: Washington Division of Geology and Earth Resources, P. O. Box 47007, Olympia, WA $98504-7007$

${ }^{2}$ Current address: 14708 SE Rupert Dr. Apt. A., Portland, OR 97267
} 
The eastern lobe on the Step Fan reached Spirit Lake by Lake Creek as a debris flow. The middle and western lobes incorporated additional sediment, heat, and water as they flowed northwestward in a channel system across the still-hot 1980 pyroclastic-flow deposits on the Pumice Plain. Most of the material (the western lobe) entered the North Fork Toutle River by Steam Creek; a lesser amount (the middle lobe) flowed northwestward down the Pumice Plain and entered Pumice Creek. The two flows united in the North Fork Toutle channel about $9 \mathrm{~km}$ from the vent and flowed $7 \mathrm{~km}$ down the North Fork Toutle River as a debris flow, before transforming to a hyperconcentrated flow. Hot rocks that were hurled onto the crater wall and crater floor (possibly including minor amounts of juvenile material) evidently melted enough snow and ice to generate a slushflow and a recessional discharge of muddy water from the crater that lasted for more than one hour.

\section{STUDY METHODS}

The earliest observation of the flow front was at 0950 Pacific Daylight Time (PDT) by Jack Hash, who was located at the U.S. Army Corps of Engineers temporary pumping station near Spirit Lake (fig. 6.1). He reported "...steaming... and a considerable mudflow flowing toward Spirit Lake"; and at 0952, "...quite a bit of water..." (6.6 km from the lava dome). At 1008, volunteer observers ("riverwatch") near Elk Rock reported a mudflow in the North Fork Toutle River near Coldwater Lake (16 km from the crater).

A helicopter carrying three U. S. Geological Survey personnel, arrived at the Mount St. Helens crater at 1012, but steam in the crater prevented us from making detailed observations of the vent area at that time. However, we flew downstream along the North Fork Toutle River valley and overtook the lahar flow front, sampling it as it passed three downstream locations. After several hours, we returned upstream to examine and sample deposits of the lahar.

More detailed study of the sedimentary characteristics of the lahar was conducted the following year as the deposits became dissected, which allowed interpretations of downstream rheological changes and estimates of deposit volume and distribution. The volume estimates allowed approximations of water content and of the

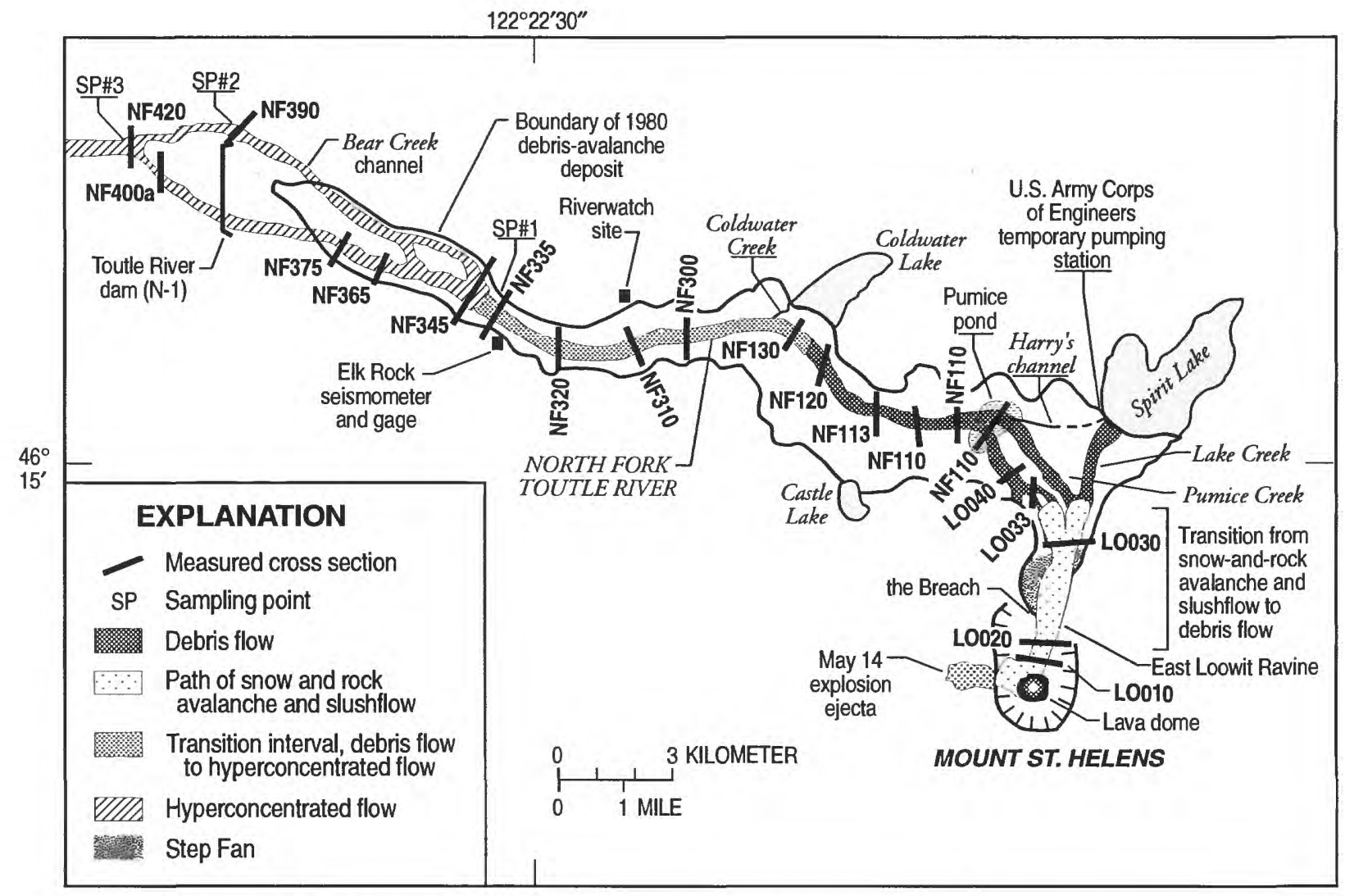

FiguRE 6.1.-Path of May 14, 1984, lahar and lahar runout and locations of selected measured cross sections. 


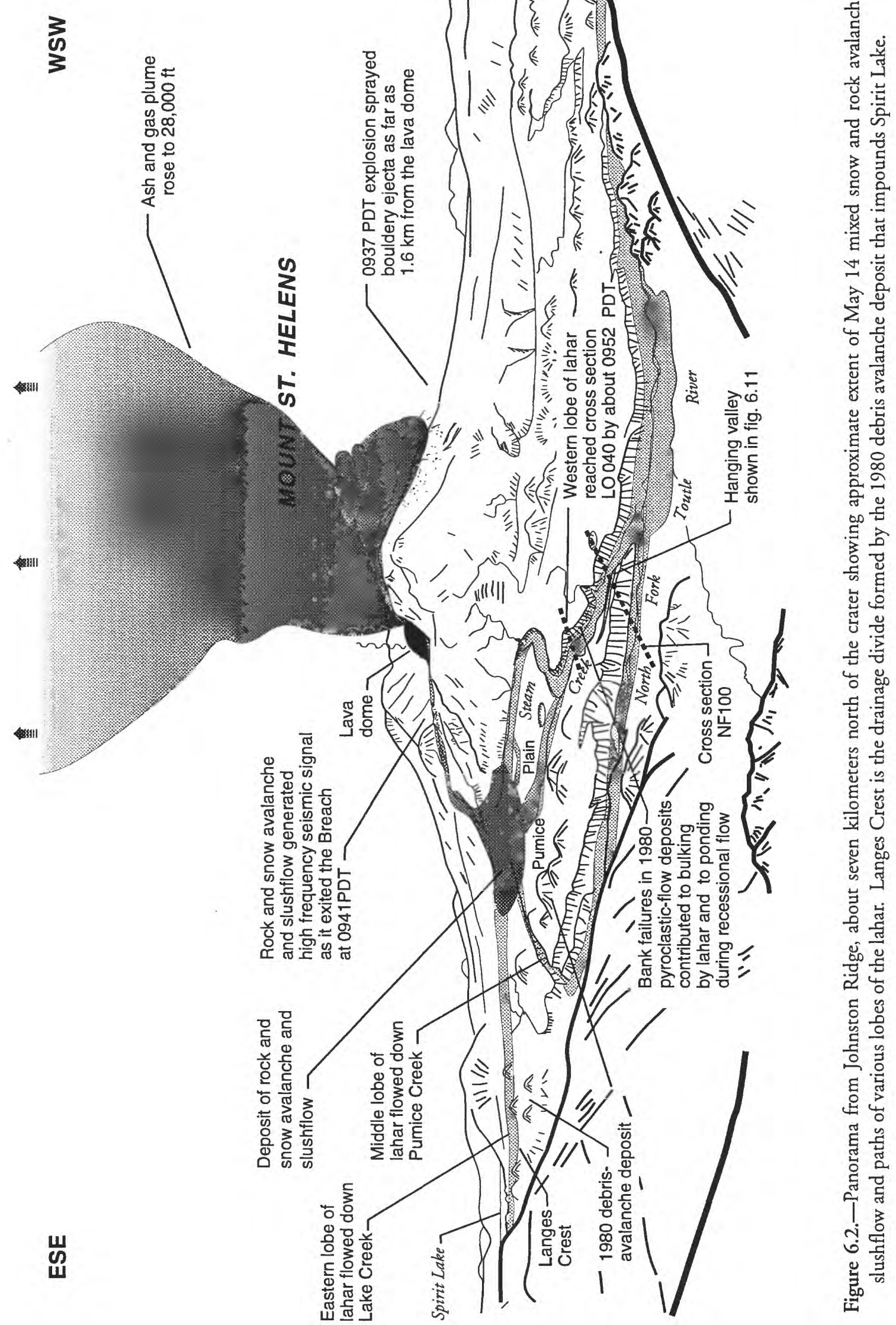


energy required to generate the incorporated water from crater snow and ice.

Channels affected by the lahar are crossed by measured cross sections that are regularly surveyed for channel evolution, geometry, and sediment budget. These cross sections were resurveyed shortly after May 14 and compared with pre-lahar data to determine the amount and nature of erosion and deposition caused by the lahar.

\section{TERMINOLOGY}

Sedimentology of Mount St. Helens lahars and associated terminology is discussed by Scott (1988). In slight contrast to his usage and that of Crandell (1971), the term labar is used in a more general sense to mean a rapidly flowing mixture of rock debris and water from a volcano (Smith and Lowe, 1991). Lahars can have sediment concentrations of more than about 80 percent by weight ( 60 percent by volume) and, thus, may be classified as debris flows (Beverage and Culbertson, 1964; Pierson and Costa, 1987). In distal reaches lahars commonly undergo dilution to byperconcentrated flows, which have sediment concentrations in the range or about 40 to 80 percent solids by weight (20-60 percent by volume)(Beverage and Culbertson, 1964; Pierson and Costa, 1987) and which form as the result of debrisflow dilution (Pierson and Scott, 1985; Scott and Dinehart, 1985; Scott, 1988). Hyperconcentrated flows have a measurable yield strength but flow more like a liquid (Pierson and Costa, 1987). Muddy floods are highly or extremely concentrated streamflow but have less than about 40 percent sediment by weight (about 20 percent by volume).

Backfill denotes slack-water deposition by debris flow in tributary channels or in the main channel (Patton and others, 1979; Kochel and Baker, 1982). Avalanche/ shushflow refers to the flow as it debouched from Loowit Ravine, where it had some qualities of a snow and rock avalanche and also those of a more fluid flow of mixed slush, rock, and snow. Diamict is a term used to describe unsorted deposits such as tills or debris-flow deposits.

\section{EYEWITNESS OBSERVATIONS ON MAY 14}

On arrival at Mount St. Helens by helicopter at 1012, we observed the muddy trace of the avalanche/slushflow extending from the crater floor west of the dome to the north-northeast and, farther to the north, a discharge of muddy water flowing through Loowit Ravine and across Step Fan. On the Pumice Plain, superelevating, muddy surges continued to trigger bank failures throughout the length of Steam Creek. These bank failures exposed 1980 pyroclastic-flow material that was still hot enough to generate small steam explosions upon contact with the flow (fig. 6.3).

In the North Fork Toutle River (from about 8 to $16 \mathrm{~km}$ from the crater), the lahar deposits already had filled the active channel to the top of its banks by the time the lahar was observed (18 minutes behind the flow front). Recessional watery surges flowed over the fresh lahar-deposit surface, creating knickpoints (fig. 6.4). The capacity of the channel had been so decreased by initial deposition from the lahar that one of these surges overtopped a terrace that had not been inundated by the

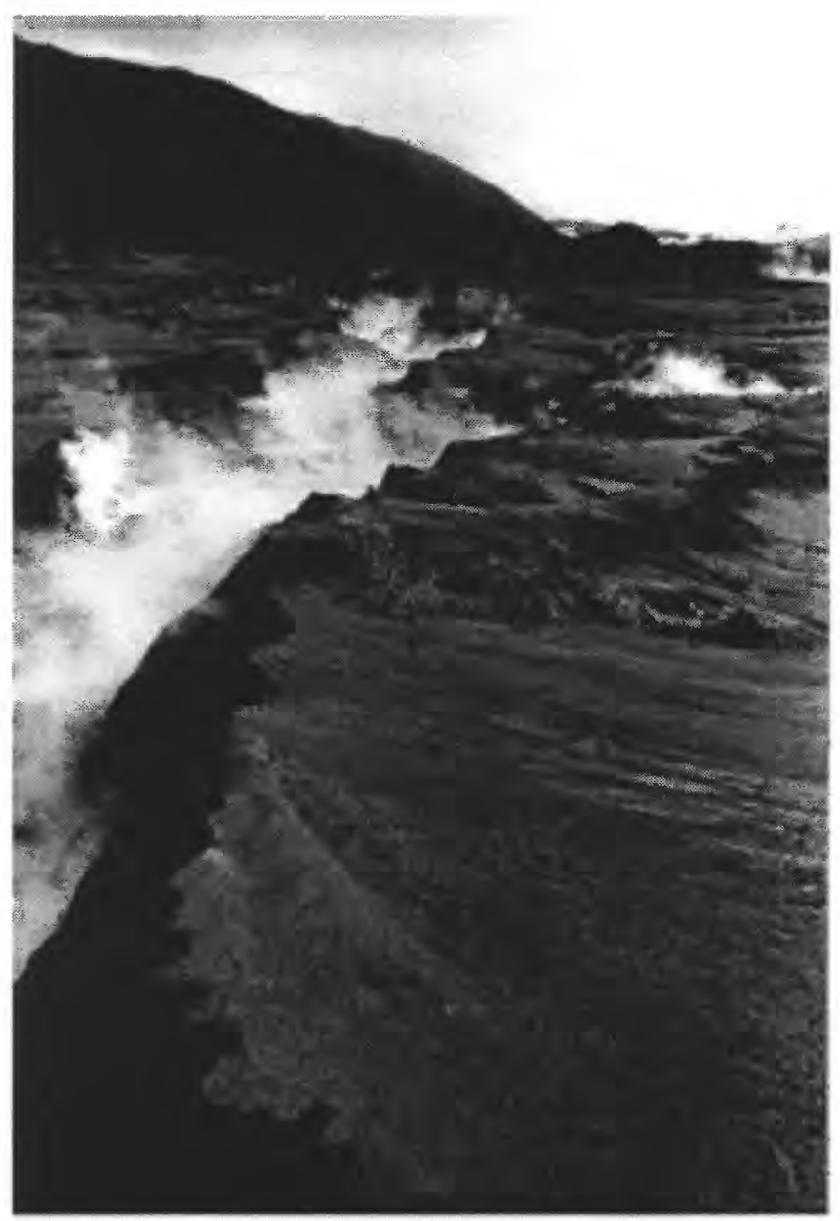

FIGURE 6.3.- Upstream view showing lahar recessional flow in the North Fork Toutle channel at about 1013 on May 14, 1984. Steam Creek enters from the right. The channel of the North Fork Toutle River is about 50 meters wide and 15 meters deep at this confluence. 
lahar flow front. The surges apparently were debris flows because the flow surface was relatively smooth, except at hydraulic jumps at knickpoints, and boulders were suspended by the flow (fig. 6.4).

Steaming from the lahar surface as a result of incorporated hot debris decreased downstream of the 1980 pyroclastic flow deposits, but isolated hot boulders continued to float or tumble along in the flow. Near the confluence of the North Fork Toutle River and Coldwater Creek $(16 \mathrm{~km}$ from the crater and only 9 minutes behind the flow front)(fig. 6.1), a series of transitory, 2- to 7-m-high wave fronts surged oblique and normal to flow in the hyperconcentrated tail of the lahar (figs. 6.5, 6.6). These waves rapidly decreased in amplitude as the discharge decreased during passage of the tail of the lahar; 20 to 30 seconds later a series of sinuous, dunelike bed forms appeared on the lahar deposit surface (fig. 6.7). Some of these regularly spaced features later were measured; they had an amplitude of $0.5 \mathrm{~m}$ and a wavelength of 50 to $80 \mathrm{~m}$ (see "Transition-reach deposits" and "Discussion" sections of this chapter).

Within a few kilometers downstream of Coldwater Creek, the North Fork Toutle channel widens to 250 to $450 \mathrm{~m}$, and during high-water periods, the stream normally has a braided form. A series of smaller standing waves were seen near cross section NF300 $(19 \mathrm{~km}$ from the crater)(fig. 6.1), unlike the large waves in the Coldwater reach. A muddy flood characterized by choppy turbulence became evident at the head of the flow near NF300, and surges were observed both at the flow front and on the surface of the flow during peak stage. The surface-wave surges seemed to move downstream faster than the flow as a whole which indicates subcritical flow.

Overtaking the flow front, we landed $24 \mathrm{~km}$ downstream from the crater (near Elk Rock gage) at 1021 to sample the flow and measure its velocity (sampling

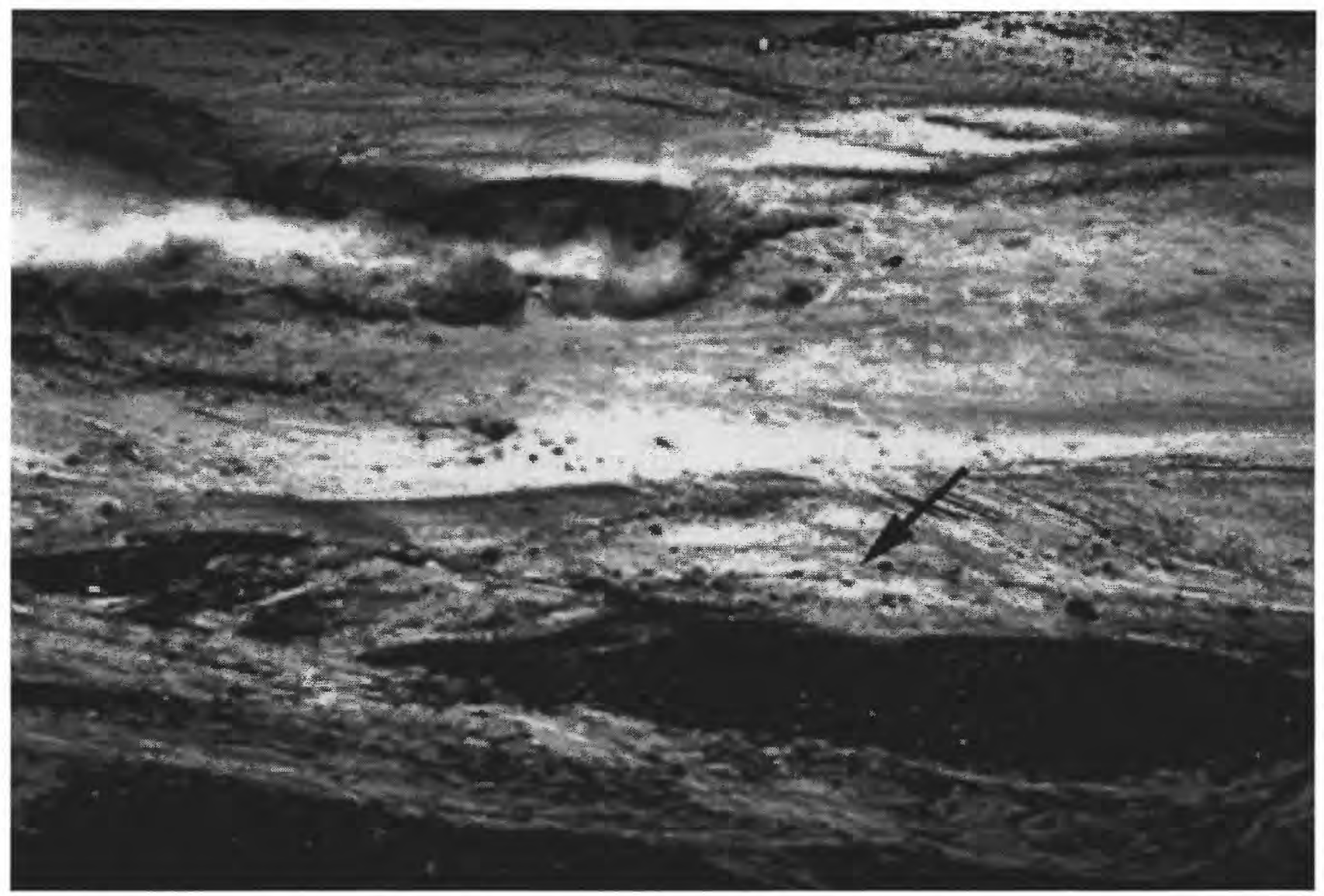

FigURE 6.4.-Side view of a recessional-flow knickpoint (upper left center of photograph) 14 kilometers from vent at about 1014. Flow is right to left. Boulder with splash ring (slightly upstream from knickpoint) is apparently supported within the flow. White spots (indicated by arrows) are hot boulders transported from the dome or exhumed from still-hot May 1980 deposits. 
station 1)(fig. 6.8). A rumbling noise was heard and felt for more than one minute before the flow came into sight $600 \mathrm{~m}$ away. We began sampling at about 1032 near the center of the channel, then moved to the side as the stage increased. Occasional surges in the thalweg were less prevalent at this sampling locality than upstream. In fact, there was no well-developed flow front, only a rapid smooth increase in stage for about 6 minutes. We did wade out knee-deep to obtain samples during peak flow at about 1039 and during flow recession at about 1046 (fig. 6.8), but these samples did not include the coarse material (tree trunks, rootballs, and boulders). Backsplashing standing waves were ephemeral and less than $0.5 \mathrm{~m}$ in height. Maximum flow temperature was estimated to be $25^{\circ} \mathrm{C}$ to $30^{\circ} \mathrm{C}$ (seasonal average is about $\left.10^{\circ} \mathrm{C}\right)$.

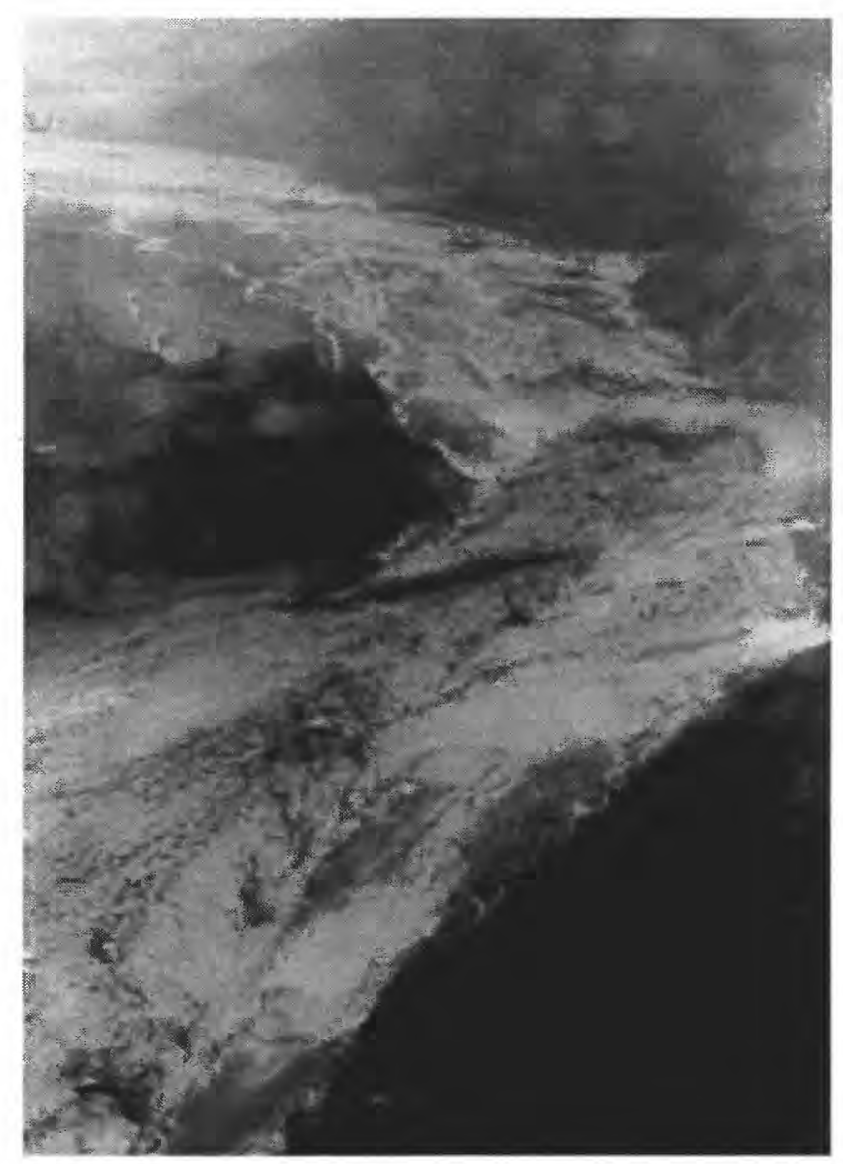

Figure 6.5.-Downstream view of North Fork Toutle River at 1016 ( 9 minutes after passage of lahar flow front) showing a series of oblique and normal wave fronts (hydraulic jumps?). Cross section NF130, 16 kilometers from crater, is near the middle of the photograph. Channel bottom is about 150 meters wide. Diffuse light spots are raindrops on the helicopter window.
One-half kilometer downstream of sampling station 1, the flow overtopped a low divide, and about 40 percent of the flow had diluted considerably at this point and had the appearance of hyperconcentrated flow. Velocity measurements were made at three more sites (sampling points 2,3, and 4) 30,33 , and $37 \mathrm{~km}$ respectively from the crater. A distinct flow front was discernible only at sampling station 2 in the dry and constricted Bear Creek channel. No surges were observed, and stage increased only gradually for about 2 minutes. At sampling points 2 and 3, the first indication of the flow was an increase in turbidity followed by considerable floating debris. At all three of these downstream sites (sampling points 2, 3 and 4) the main body of the flow was dark brown in color and had a choppy, turbulent surface. Longitudinal bars were deposited rapidly during and after passage of the flow front.

\section{LAHAR DEPOSITS}

The changing character of the May 14 deposits downstream indicates that transformation from slushflow to debris flow occurred 2 to $7 \mathrm{~km}$ from the crater and that transformation from debris flow to hyperconcentrated flow occurred 15 to $22 \mathrm{~km}$ from the crater (table 6.1) (figs. 6.9, 6.10). Void space from melting of constituent snow/ice granules, which formed about 5 percent of the matrix in the Step Fan reach, disappeared within a few kilometers downstream. Fragile clasts of unconsolidated bank material as large as $2 \mathrm{~m}$ that were rafted by the lahar were present on the surface of the deposit between 3 and $16 \mathrm{~km}$ downstream of the lava dome, indicating high yield strength and probably plug flow (Johnson, 1970; Enos, 1977). Absence of the fragile clasts downstream of Coldwater Creek (fig. 6.1) indicates a decrease in the yield strength of the lahar that corresponds to a transformation from debris flow to hyperconcentrated flow. Detailed descriptions of the deposits in specific reaches are provided in the following paragraphs.

\section{PROXIMAL-REACH DEPOSITS}

From the mouth of Loowit Ravine, the microhummocky avalanche/slushflow deposit extended about $1 \mathrm{~km}$ onto Step Fan. The deposit averaged about $0.5 \mathrm{~m}$ thick and was as much as $2 \mathrm{~m}$ thick where a preexisting channel was filled. Although the avalanche/ slushflow was predominantly depositional on the upper 


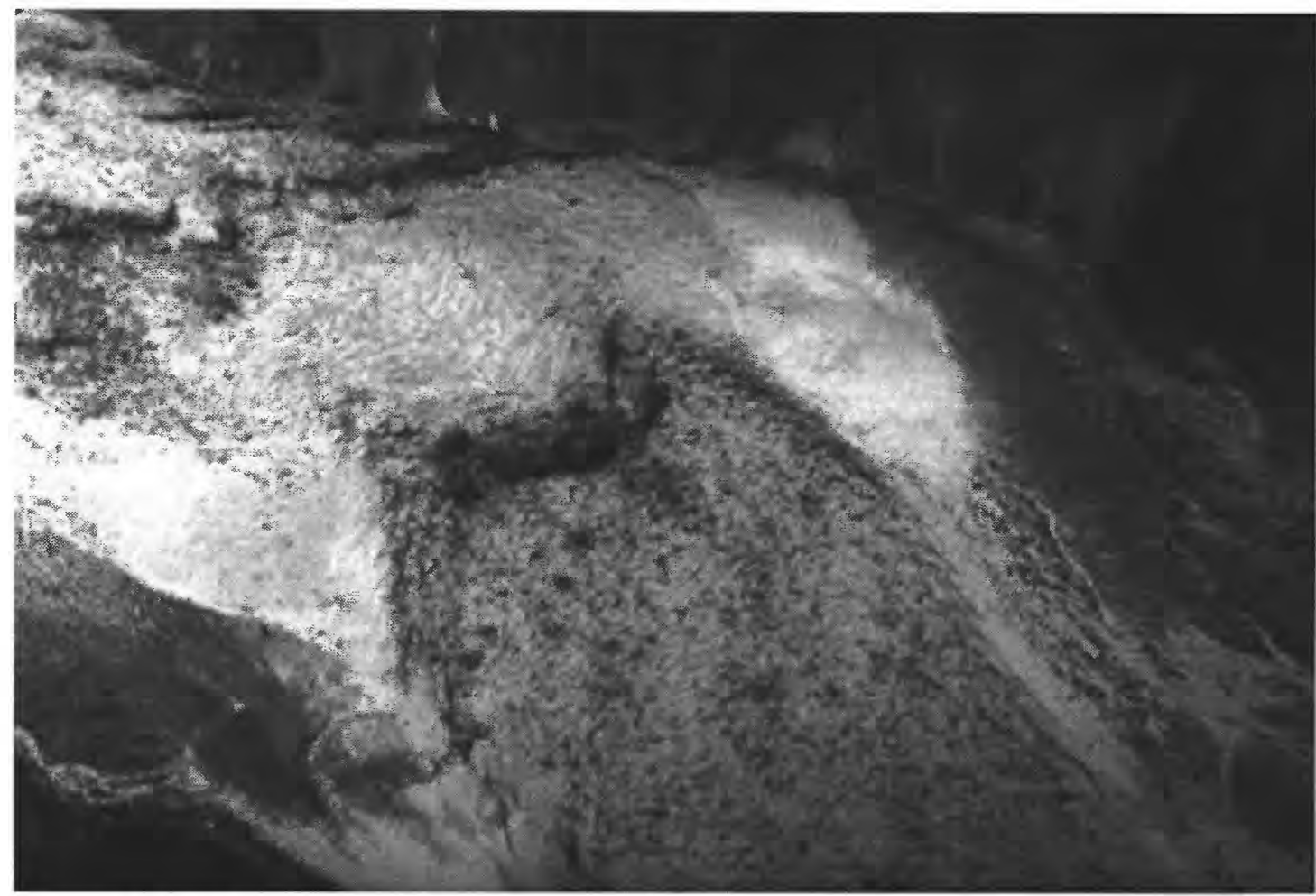

FigURE 6.6.-Close up of bow-shaped wave front (hydraulic jump?) shown at right center of figure 6.5. Flow is lower right to upper left. Average height of wave is 2 to 3 meters.

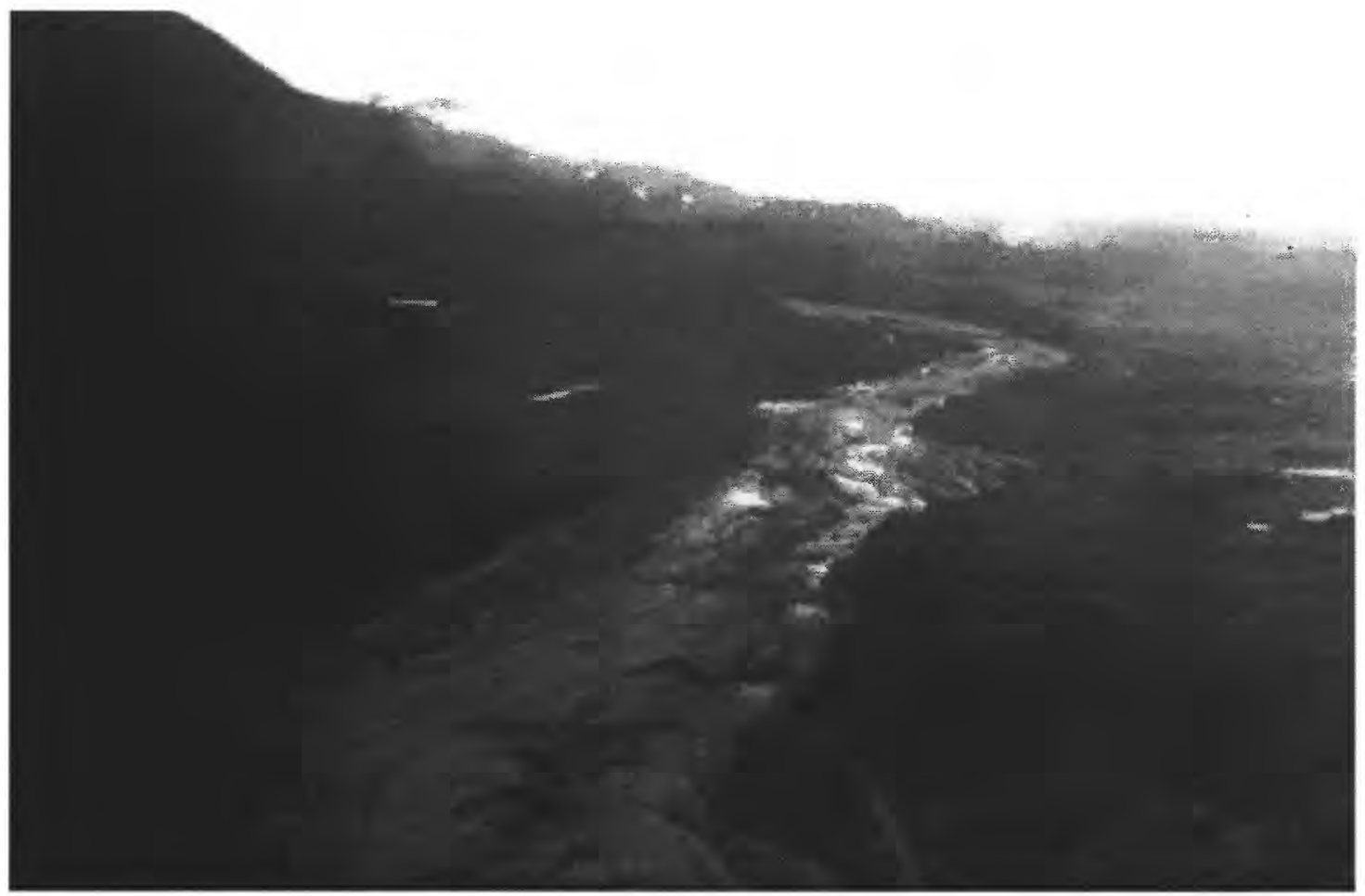

FIGURE 6.7.-Upstream view of the North Fork Toutle River and sinuous, dune-like features (bed forms?) 16 kilometers downstream from the vent immediately after passage of recessional surge shown in figures 6.5 and 6.6. Measured cross section NF130 is located midway through the lower left quarter of the photograph. 

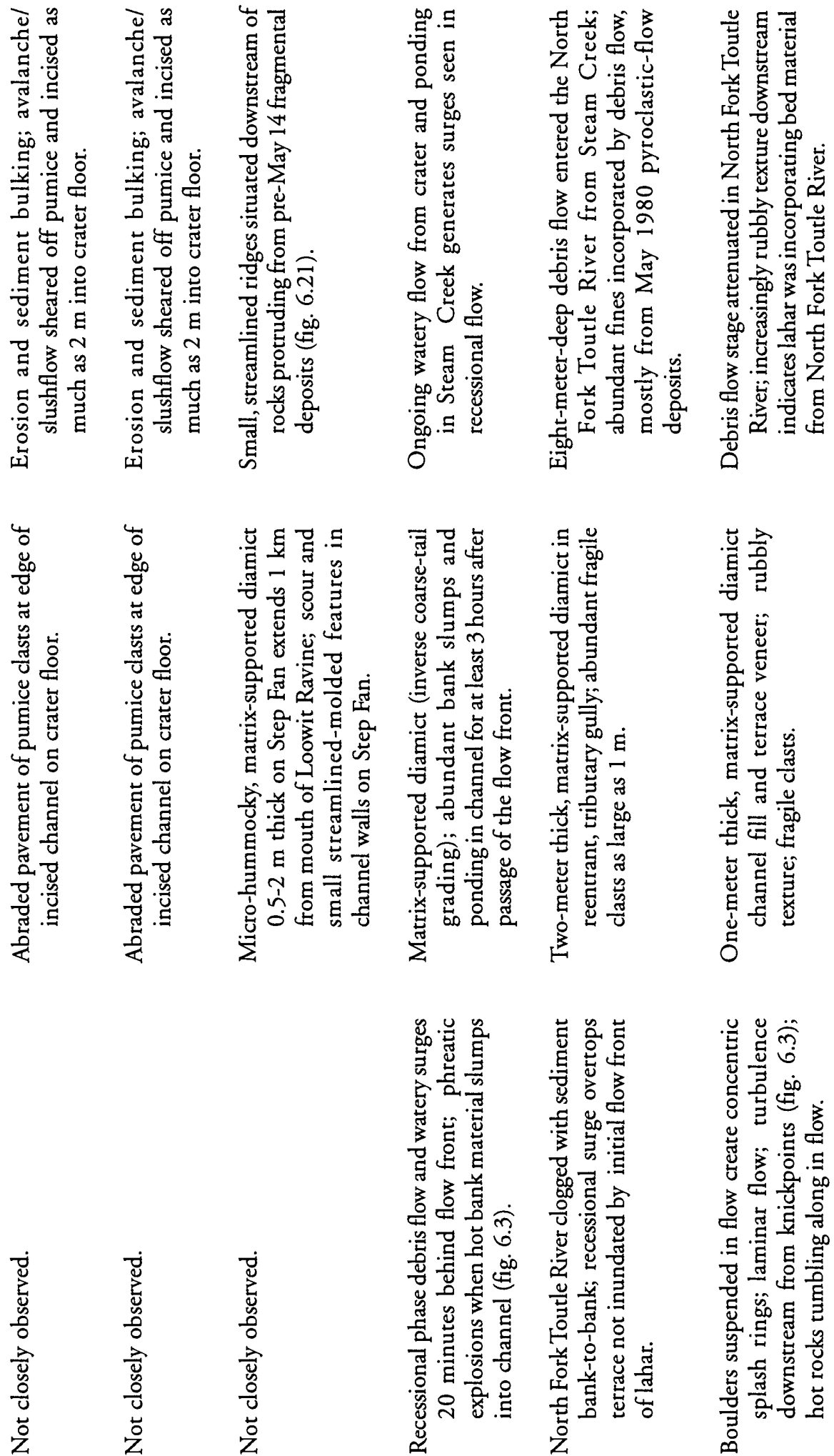

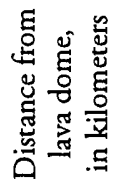
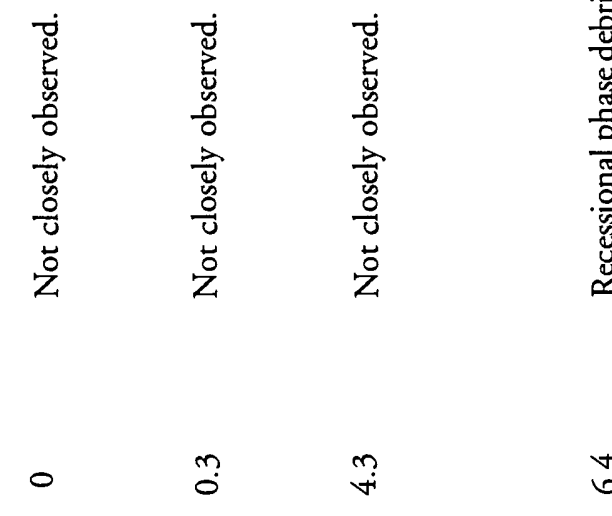

ঋ゙:

$\underset{\infty}{\infty}$

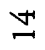




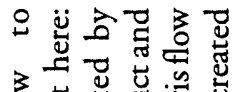
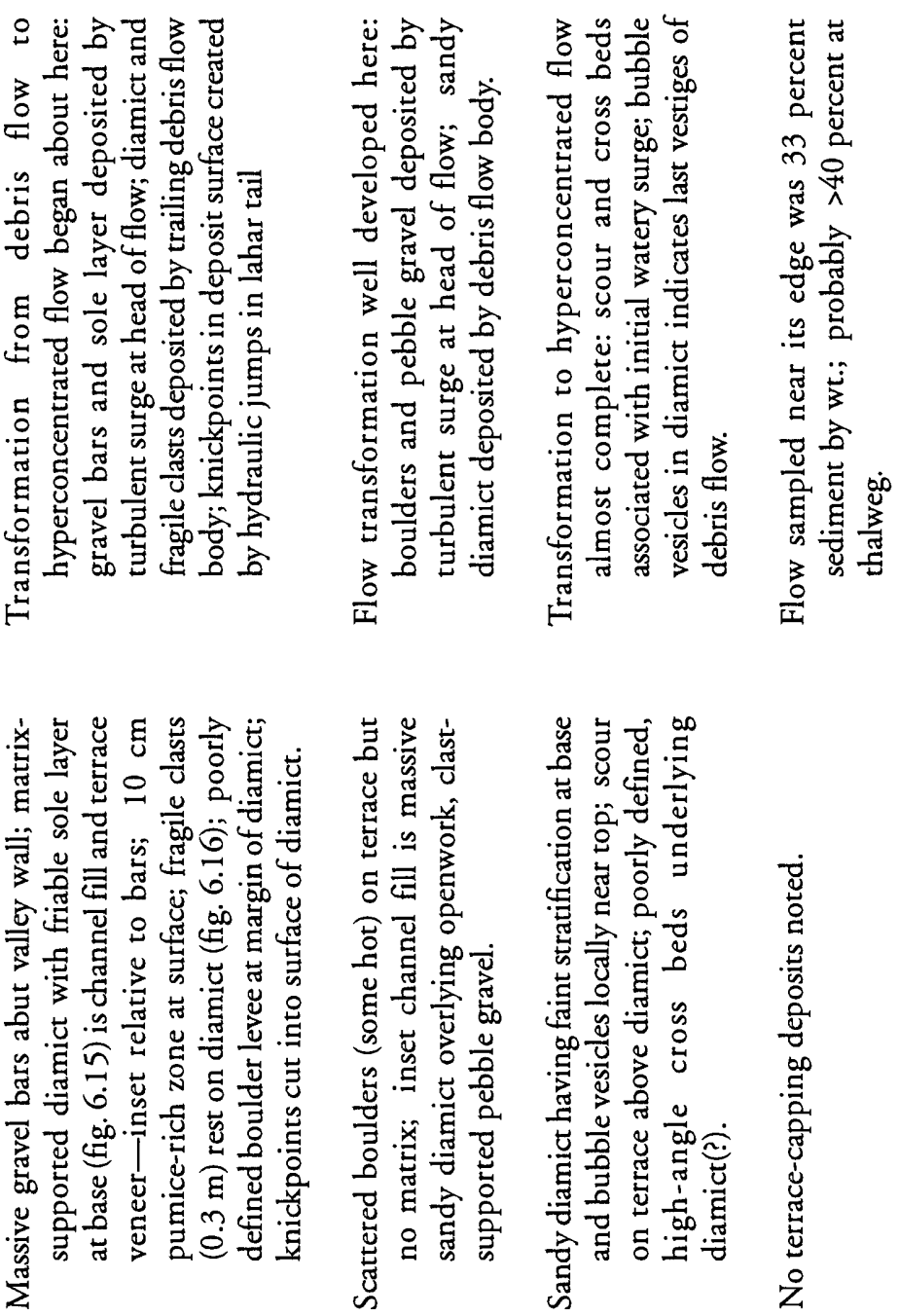

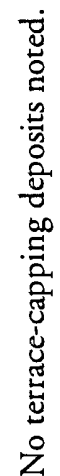
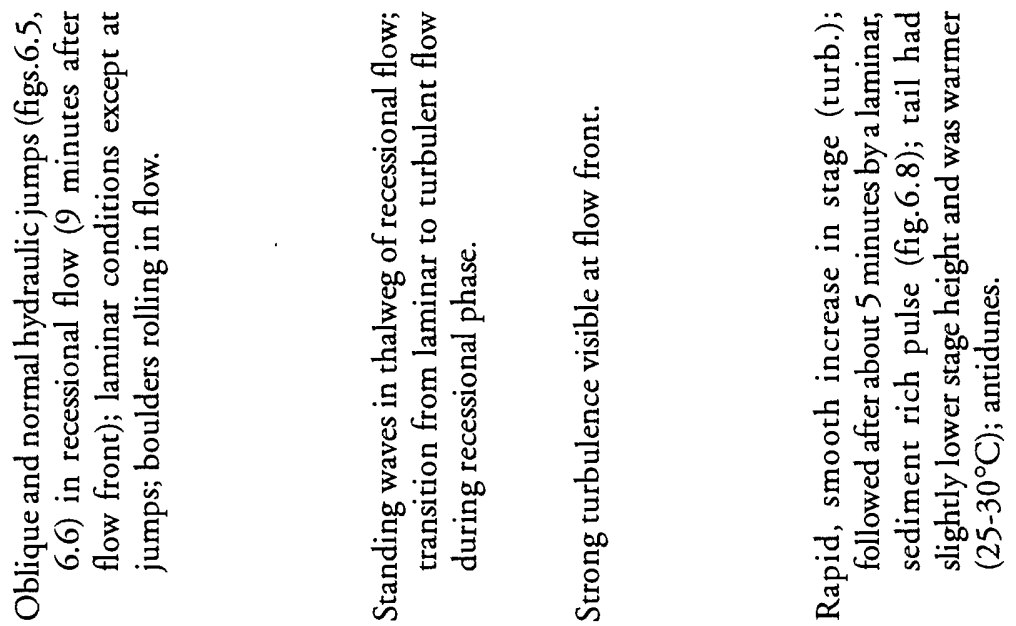

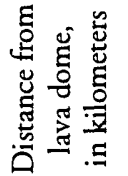

$\stackrel{0}{-1}$

2

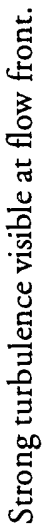

氖歪

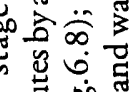

$\Xi$.

造

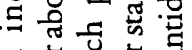

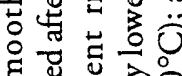

동. 운

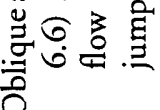

ํㅡㅇ 컶

艺

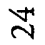


reaches of Step Fan, recessional flow incised a $1 \mathrm{~m}$ channel at cross section LO030 (fig. 6.1). Within $4 \mathrm{~km}$ of the crater, deposits consisted of a loose and openwork diamict because of the high void space and interstitial water content, both of which are attributed to melting of entrained snow and ice grains. The deposits $6 \mathrm{~km}$ from the vent had much less void space and were similar in appearance to the compact debris-flow deposits farther downstream.

Several distributary gullies from Step Fan join to form Steam Creek and slushflow material entering the gullies reached Steam Creek at slightly different times (fig. 6.2). As a result, deposits slightly downstream of cross section LO033 in Steam Creek include successive layers of texturally distinct diamicts, attributable to the different arrival times of the material flowing by different paths.
Nested terrace deposits were exposed at LO033. An upper 1.5-m unit had a high percentage of void spaces (from constituent snow), but a lower (and later) $0.3-\mathrm{m}$ unit had minimal void space.

Considerable recessional erosion in Steam Creek limited deposits to areas of backfill in gullies tributary to it and to overbank veneers on terraces. A 1.6-m-thick matrix-supported diamict was deposited as a backfill in a reentrant hanging tributary $7 \mathrm{~m}$ above the bed of Steam Creek (figs. 6.11, 6.12). This unit has inverse coarse-tail grading and contains boulders as large as $0.8 \mathrm{~m}$ in diameter. Texturally similar deposits are present several kilometers downstream where a diamict as thick as $2 \mathrm{~m}$ was deposited in mid-channel, near-overbank settings.

At the mouth of Steam Creek, numerous fragile clasts consisting of deformed blocks of channel-bank material

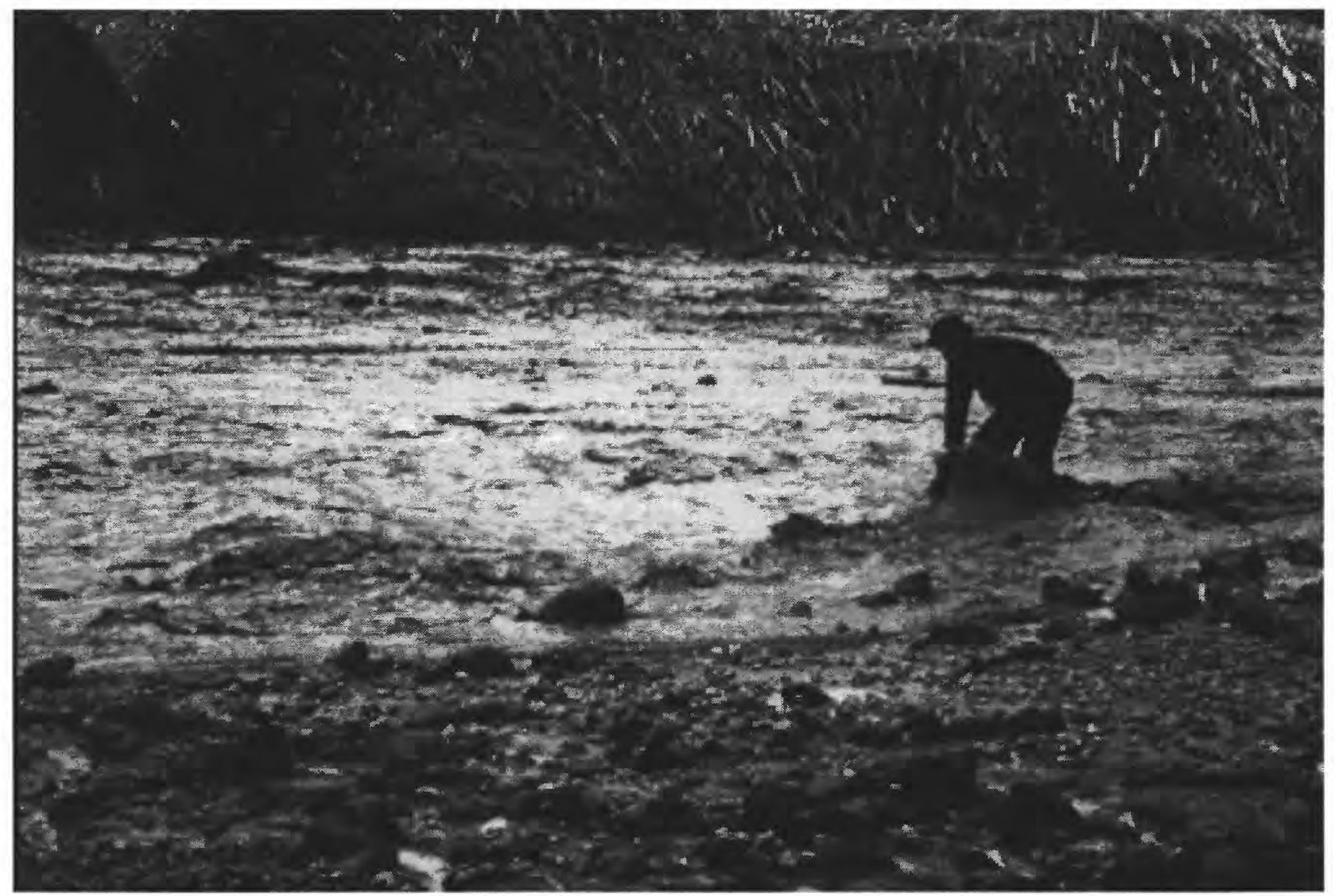

FiguRE 6.8.-Sampling of the sediment-discharge peak at 1046, 24 kilometers downstream of the crater (at measured cross section NF335). A velocity of 2.3 meters per second was calculated from flow runup on the sampler's leg. Metal grommets on the sampler's boot and on sieves that were used to process these samples became corroded. Apparently this corrosion was caused by dissolved salts from hydrothermally altered deposits incorporated by the lahar because $\mathrm{pH}$ of the dip samples ranged only from 6.4 to 7.4. Trees visible on the opposite shore were blown down during the May 18, 1980, eruption. Channel width is about 400 meters. 
averaged $0.5 \mathrm{~m}$ in diameter, although some clasts were as large as $2 \mathrm{~m}$ in diameter. These fragile clasts had floated on or near the surface of the flow.

Dissection of deposits near the mouth of Pumice Creek (fig. 6.1) exposed slump-block material from the channel walls that was overlain by $0.5 \mathrm{~cm}$ of silt and by a 20-cm-thick layer of sandy, pebble- and cobble-rich diamict. This stratigraphic relation indicates that a secondary surge occurred after the slumping. Such surging behavior by debris flows is common in eyewitness

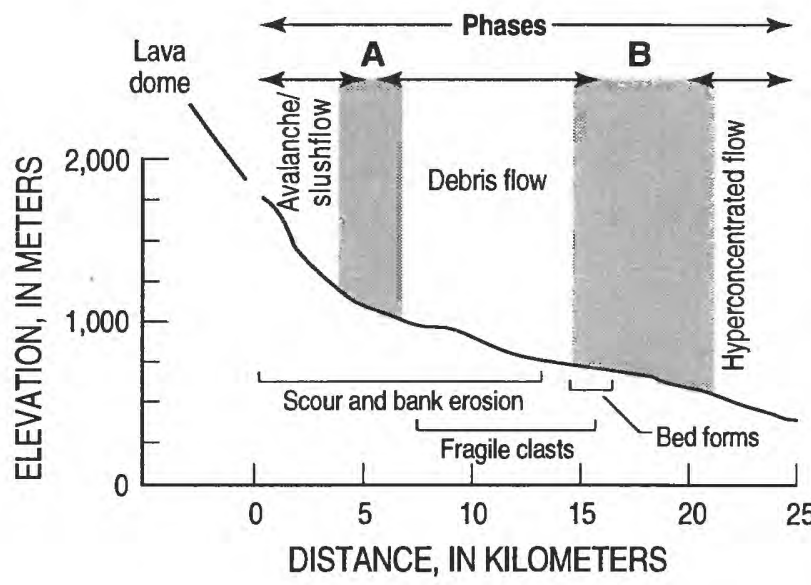

Figure 6.9.-Longitudinal profile of the North Fork Toutle River from the crater to Elk Rock showing $A$, transition interval from slushflow to debris flow, and $B$, the transition interval from debris flow to hyperconcentrated flow. Extent of bed forms preserved in the lahar deposit surface (as shown in figs. 6.17 and 6.18) is also shown.

reports where boulder snouts or channel-wall slumps dam up a flow (Blackwelder, 1928; Sharp and Nobles, 1953; Costa and Williams, 1984). Slump blocks at the confluence of the North Fork Toutle River with Steam Creek and Pumice Creek evidently dammed the flow temporarily in those gullies, for no large boulder levees were present. The silt between the units probably was deposited during temporary ponding. Failure of the debris dams probably contributed to the surging that we observed from the air (for example, Pierson, 1980, p. 237 ) and probably provided considerable amounts of loose material that was easily incorporated by recessional stages of the lahar. Slumping and associated ponding continued for at least 3 hours after passage of the flow front (fig. 6.13). By 1530, most of this material had been flushed and a channel reestablished.

\section{TRANSITION-REACH DEPOSITS}

Two depositional facies occur $16 \mathrm{~km}$ downstream from the vent (cross section NF130)(fig. 6.1); coarse, openwork longitudinal gravel bars nested against the valley wall (fig. 6.10) and 0.2- to 1 -m-thick sandy, matrixsupported diamict in mid-channel and channel-margin settings (fig. 6.14). The diamict overlies a discontinuous, poorly bedded sand and gravel which grades upward into 10 to $20 \mathrm{~cm}$ of massive sandy gravel, also below the diamict. The openwork gravel bars and sub-diamict material apparently were deposited by the initial surge, and the diamict by the body of the lahar (see table 6.1.). Together, the two facies provide evidence that the lahar was transforming from debris flow to hyperconcentrated flow.

The bars (deposited first) were as thick as $0.5 \mathrm{~m}$, slightly convex upward, and irregularly spaced. Erosional trimlines and splash marks on the channel wall were situated over the bars locally. Although the sorting value $(2.79 \phi)$ for the bar sediments is low (Folk, 1974) and the deposit was structureless, the overall shape of the bars was streamlined. Apparently the bars were deposited rapidly at peak flow in a zone of mixing at the head of the lahar. The dunelike shape of the bars could have

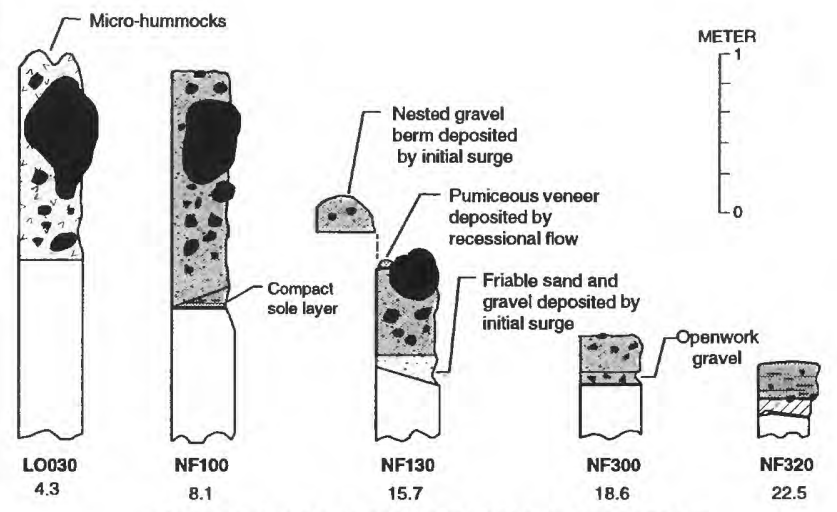

CHANNEL DISTANCE FROM LAVA DOME, IN KILOMETERS

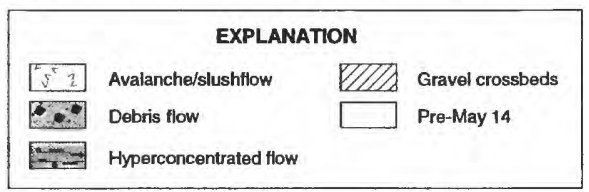

FIGURE 6.10.-Sequential schematic stratigraphic sections showing upstream-downstream textural changes and depositional facies associated with the May 14, 1984, lahar. Names of corresponding measured cross sections are shown below each section. 
resulted from depositional processes and/or from erosional streamlining by trailing flow. These bars are smaller than, but probably analogous to the whaleback bars described by Scott (1988).

Fragile clasts of fragmental material from the 1980 debris-avalanche were present on the surface of the diamict. As large as $25 \mathrm{~cm}$, these fragile clasts were nested within the aforementioned bars (toward the center of the channel) at the extreme upstream reaches of the transition reach (fig. 6.15). The diamict at this location was deposited by a trailing flow that immediately followed the bar-depositing surge. This diamict is covered by 2 to $10 \mathrm{~cm}$ of pumice and contains high-angle, knickpointlike features $20 \mathrm{~cm}$ high that are regularly spaced 50 to $80 \mathrm{~m}$ apart on the surface of the diamict. A poorly defined boulder levee lies along one edge of the diamict on a terrace. Matrix clay content for a sample of the diamict that was obtained while the deposit was still thixotropic was 1.5 percent by weight, the highest value for any sample of this lahar deposit.

Additional evidence of flow transformation is found three kilometers farther downstream, where the channel widens at cross section NF300 (fig. 6.1). There the channel-fill deposit has two textures: a massive, clastsupported, openwork basal layer, 5-13 cm thick, composed of pebble gravel; and an overlying, inversely graded, sandy diamict $30 \mathrm{~cm}$ thick. The gravel was deposited rapidly by the water-diluted surge as it spread out over the wider channel. The gravel was then immediately overrun by the less-diluted body of the flow. The gravel is probably correlative with the basal layer at NF130. Overbank deposits that were 13 to $19 \mathrm{~km}$ from the crater include longitudinal arrays of clustered boulders as large as $1.5 \mathrm{~m}$. These were left as overbank deposits when one or more

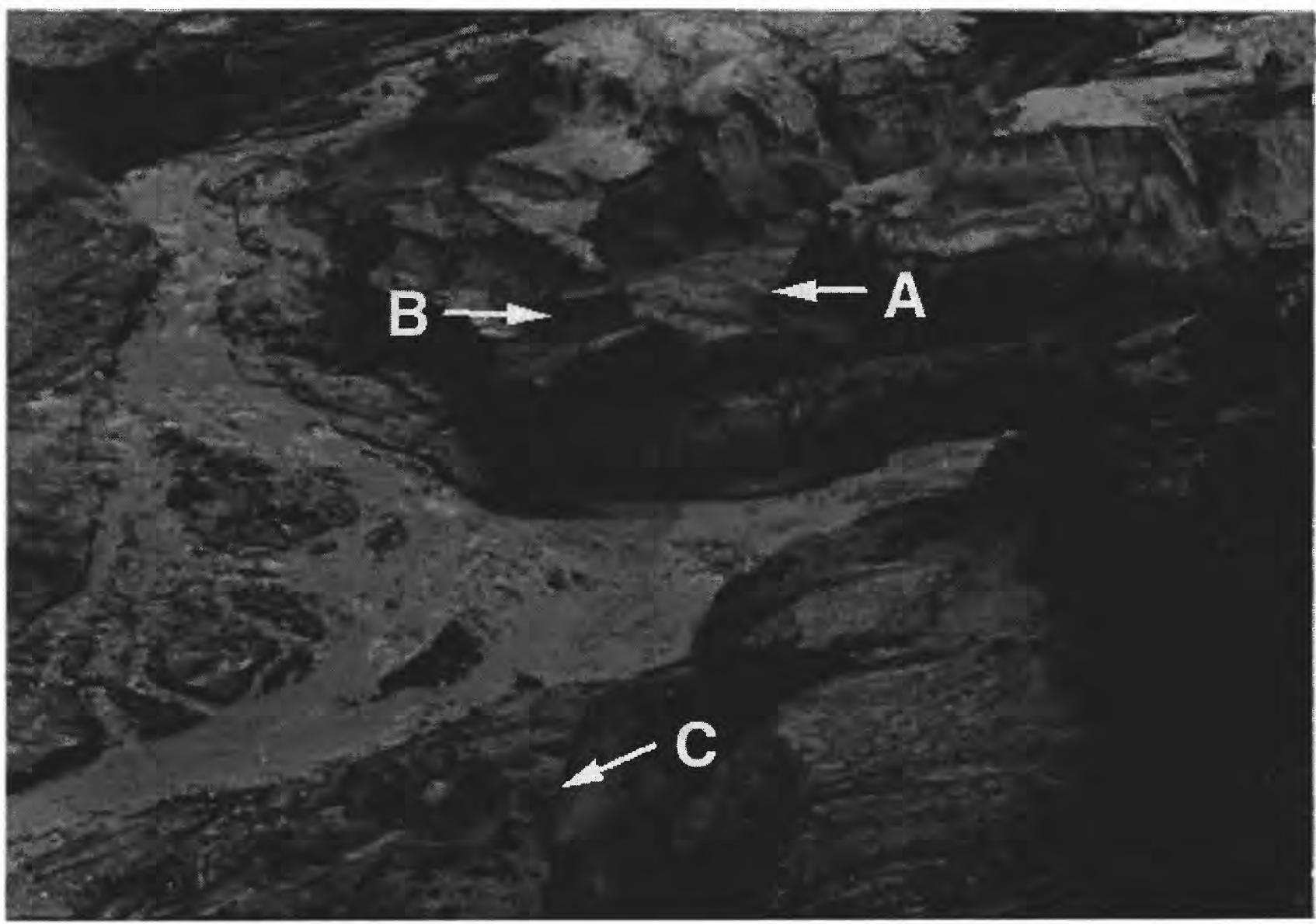

FiguRE 6.11.-Aerial oblique view eastward at 1530 showing confluence of Steam Creek (right center) with North Fork Toutle River, about 9 kilometers downstream of the crater. $A$. Hanging tributary gully is site of backfill deposit shown in fig. 6.12; $B$. Scoured right bank of Steam Creek; and $C$. Fragile clasts littering the surface of the lahar deposit. The gullies are cut into pyroclastic-flow deposits of May 18, 1980. 
boulders rolled to a stop and trailing clasts collided with them and stopped ("Keystone-cop" style).

The last evidence of flow transformation was found $21 \mathrm{~km}$ from the vent (cross section NF310)(fig. 6.1) where the main depositional unit is a 15 - to $25-\mathrm{cm}$-thick sandy diamict having faint stratification near the base. The lack of matrix-supported clasts larger than $3 \mathrm{~cm}$ at the NF310 cross section provides evidence that the yield strength of the flow had been significantly reduced, however, voids (inferred to be bubble vesicles) in the upper part of the deposit indicate the last vestiges of debris-flow emplacement. High-angle cross beds of gravel underlying the diamict may have been deposited by the watery surge that we observed ahead of the hyperconcentrated flow at this location.

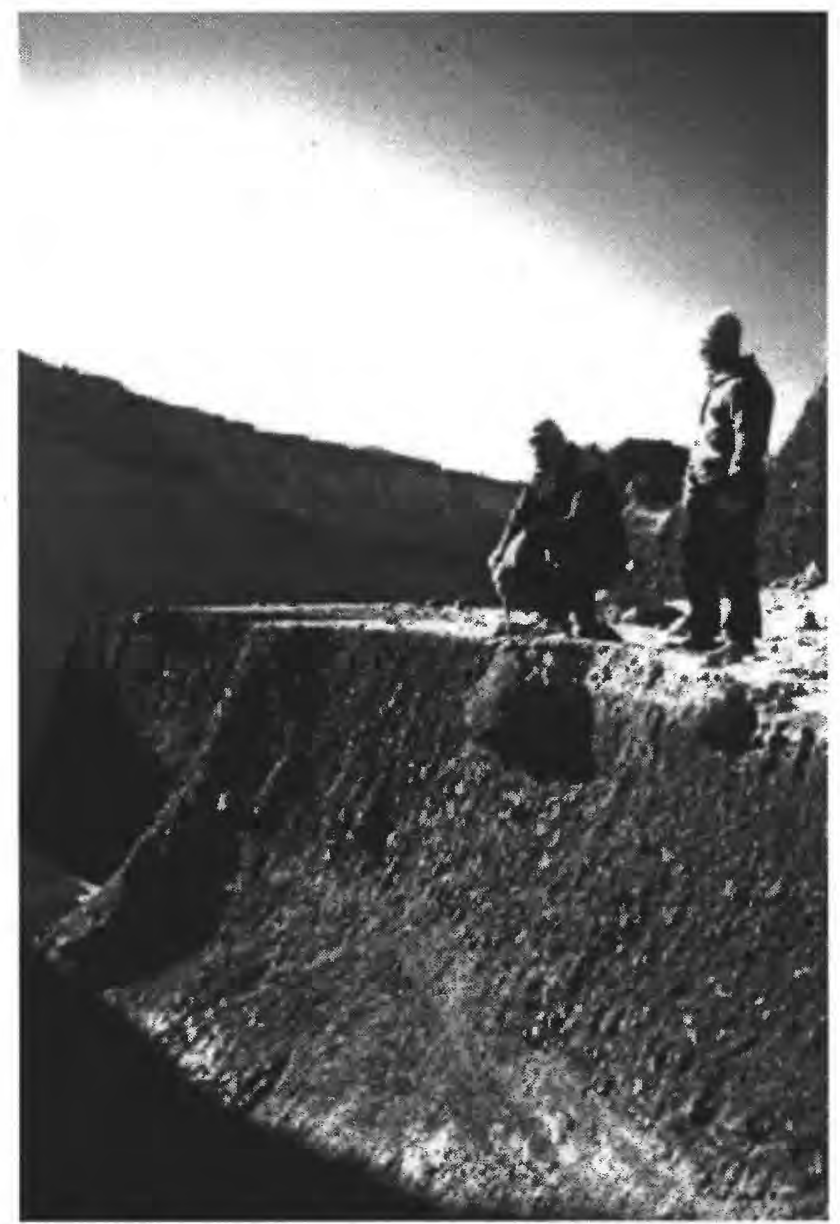

Figure 6.12.-View of diamict deposited as backfill in hanging tributary shown in fig. 6.11 (8 kilometers from the crater). Left bank of Steam Creek in background. Average thickness of deposit is 1.7 meters. Note boulders that were suspended in the flow.

\section{ESTIMATED DEPOSIT VOLUME, WATER CONTENT, AND HEAT ENERGY IMPLICATIONS}

Total primary deposit volume (dry) for the lahar was $5 \times 10^{5} \mathrm{~m}^{3}$. This value was calculated by digitizing mapped channel deposits and by using changes in three manometer gage readings of the level of Spirit Lake to calculate the volume of the eastern lobe of the lahar. All Spirit Lake manometer gages showed sustained increases of $0.1 \mathrm{ft}(0.03 \mathrm{~m})$ immediately following the lahar (Dallas Childers, U.S. Geological Survey, written commun., 1984). If water accounted for 50 percent of the initial (saturated) deposit volume (as interpreted for a debrisflow pulse followed by a smaller volume of hyperconcentrated recessional flow), then total water volume for all lobes of the May 14 lahar was about $5 \times 10^{5} \mathrm{~m}^{3}$. Because of the much greater amount of sediment bulking by the middle and western lobes of the lahar, the significant water contained in those lobes could have been incorporated channel water and ground water. Analysis of discharge data (U.S. Army Corps of Engineers, 1984) indicates that approximately $4.2 \times 10^{4}$ $\mathrm{m}^{3}$ of water occupied the North Fork Toutle River channel in the affected reach. An additional $6 \times 10^{4} \mathrm{~m}^{3}$ of water was available as ground water within the interstices of eroded sediment, so at least 70 percent of the water $\left(2.5 \times 10^{5} \mathrm{~m}^{3}\right)$ in the middle and western lobes probably originated as melted snow granules from the crater. Because little channel water was available for the eastern lobe between the crater and Spirit Lake, water contained in that lobe amounted to $1.5 \times 10^{5} \mathrm{~m}^{3}$. Therefore, the total volume of water derived from the crater was $4 \times 10^{5} \mathrm{~m}^{3}$, about 10 percent of the size of a transient lake that formed in the crater following the explosion of March 19, 1982 (Waitt and others, 1983; Pierson, chap. 2, this volume). The latent heat of fusion for water is $1.8 \times 10^{5} \mathrm{~J} / \mathrm{m}^{3}$. Therefore, at least $7.1 \times 10^{10} \mathrm{~J}$ were required to melt the crater ice/snow incorporated in the May 14 lahar.

\section{VELOCITY AND DISCHARGE}

Mean velocity values for the May 14 flow were calculated using seismic signals and times reported by observers. Inception of flow from the crater was inferred to be at 0941 , at the onset of a second pulse of seismic signals having a slightly higher frequency than the first pulse. Calculated average velocities (table 6.2) ranged from $9.6 \mathrm{~m} / \mathrm{s}$ (within $6.4 \mathrm{~km}$ of the crater) to $2.3 \mathrm{~m} / \mathrm{s}$ 
FigurE 6.13.-Downstream aerial oblique view of Steam Creek (about 6 kilometers from the lava dome) at 1336 showing ponding 3 hours after passage of the lahar flow front. Note slumps of channel wall in the right and upper right part of the photograph and freshly deposited material. Height of the channel walls is about 13 meters.
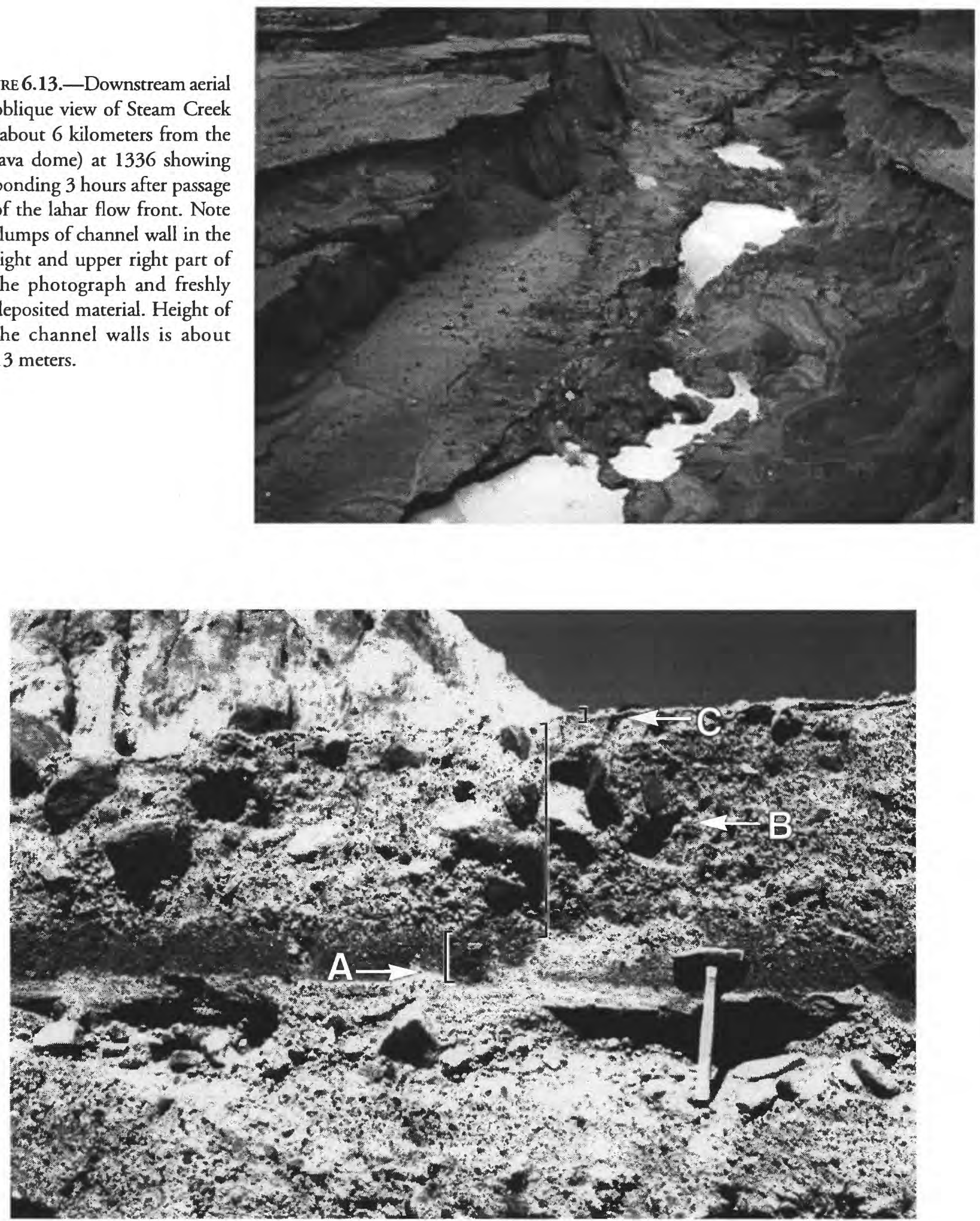

FigURE 6.14.-Terrace-capping deposits on the right bank of the North Fork Toutle River about 16 kilometers from the lava dome show evidence of the beginning of the transition from debris flow to hyperconcentrated flow. Depositional sequence includes: Subunit $A$, a bedded sand and gravel grading upward into massive sand and depleted in coarse clasts; subunit $B$, a friable massive sand and gravel; and subunit $C$, a thin (0-10 centimeter), friable, pumice-rich sandy layer.. The sequence records a leading hyperconcentrated flow, $(A)$, which transitioned into a debris-flow phase (note boulders suspended in matrix) $(B)$, and a final, more watery resessional surge $(C)$. Rock hammer is 35 centimeters long. Flow direction is right to left. 
(38 km from the crater). The latter value correlates with surface velocities measured by timing flotsam. Measurements of flow superelevation from mudlines at a channel bend near cross section LO033 $(6.2 \mathrm{~km}$ from the lava dome) yielded a calculated velocity of $9 \mathrm{~m} / \mathrm{s}$. Actual velocity values for specific reaches were undoubtedly higher or lower than the mean values derived from eyewitness observations.

Instantaneous peak discharges for the lahar were calculated from surveyed mudlines and cross-sectional areas using the computed mean velocities. The western distributary lobe had an instantaneous peak discharge of $3,400 \mathrm{~m}^{3} / \mathrm{s} 8.1 \mathrm{~km}$ from the vent (table 6.2). The combined peak discharge for the other two lobes was about $500-1000 \mathrm{~m}^{3} / \mathrm{s}$, most of which flowed into Spirit Lake (eastern lobe).

\section{DISCUSSION}

\section{TRANSFORMATION OF MIXED AVALANCHE AND SLUSHFLOW TO DEBRIS FLOW}

Initial sediment bulking by the slushflow occurred in Loowit Ravine, which is cut into 1980 fragmental deposits in the area of the Breach and into the older lava flows and volcaniclastics composing the Mount St. Helens edifice. However, the downstream textural changes, distribution of deposits, and sustained stage of the western distributary lobe of the lahar indicate that most sediment bulking on May 14 occurred within Steam Creek, a channel which is cut in unwelded pyroclasticflow material from the May 18, 1980, eruption. Ackroyd

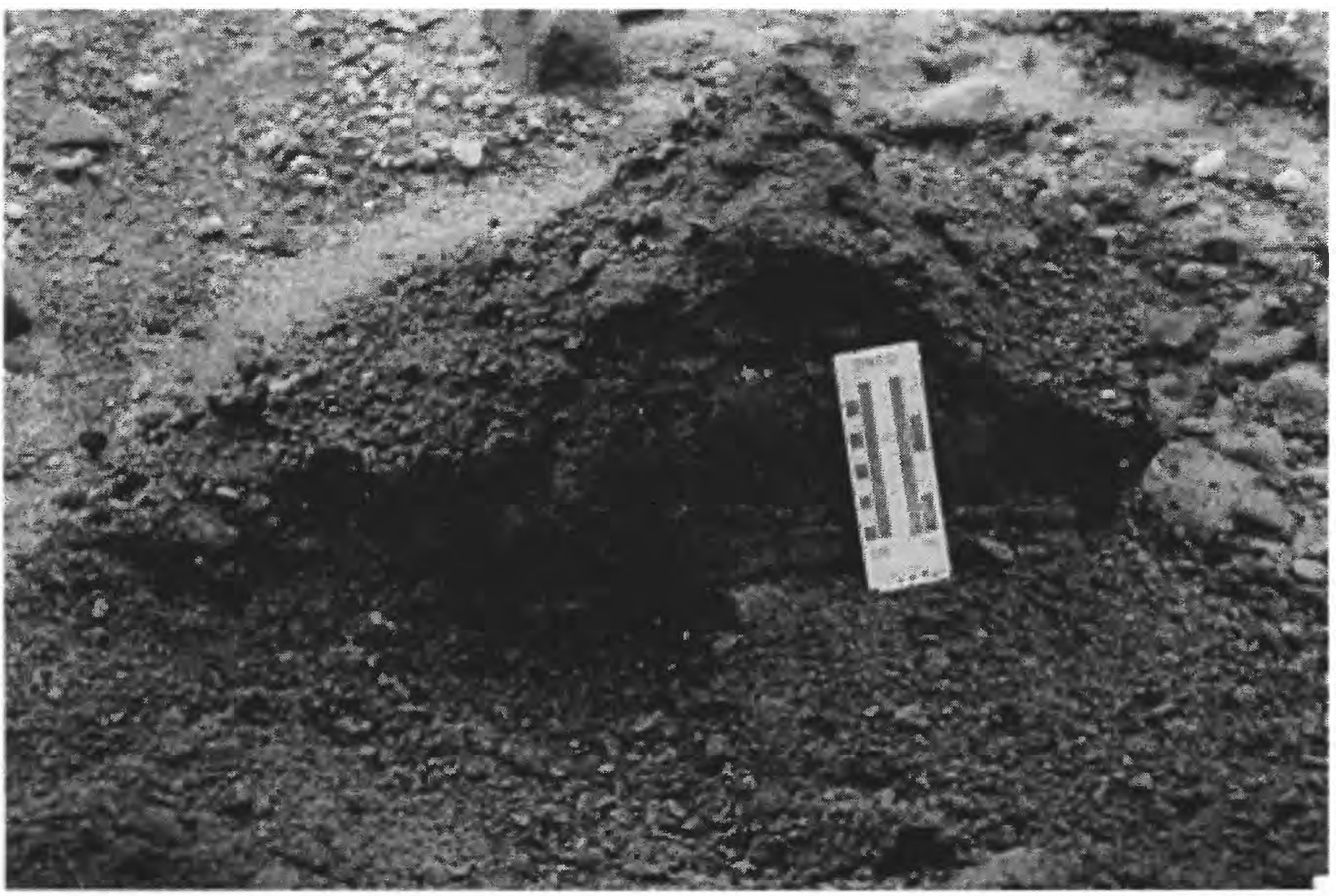

FiguRE 6.15.-Cross section of dacite-breccia fragile clast rafted by the May 14, 1984, lahar, 16 kilometers from the lava dome. 
TABLE 6.2.-Velocity, discharge, and associated channel data for May 14, 1984, lahar. Method for calculating respective times and velocities is noted under values. All cross sections more than $5 \mathrm{~km}$ from the lava dome are in the North Fork Toutle River.

[km, kilometers; $\mathrm{m} / \mathrm{m}$, meters per meter; $\mathrm{m} / \mathrm{s}$, meters per second; $\mathrm{m}^{3} / \mathrm{s}$, cubic meters per second; $\mathrm{m}^{2}$, square meters]

\begin{tabular}{|c|c|c|c|c|c|c|}
\hline $\begin{array}{c}\text { Cross } \\
\text { section }\end{array}$ & $\begin{array}{l}\text { Distance from } \\
\text { lava dome }(\mathrm{km})\end{array}$ & $\begin{array}{l}\text { Channel slope } \\
\text { in } 1984(\mathrm{~m} / \mathrm{m})\end{array}$ & $\begin{array}{l}\text { Flow front } \\
\text { arrival, PDT }\end{array}$ & $\begin{array}{l}\text { Velocity } \\
(\mathrm{m} / \mathrm{s})\end{array}$ & $\begin{array}{l}\text { Discharge } \\
\left(\mathrm{m}^{3} / \mathrm{s}\right)\end{array}$ & $\begin{array}{l}\text { Net erosion }(-) \text { or } \\
\text { deposition }(+),\left(\mathrm{m}^{2}\right)\end{array}$ \\
\hline LO 010 & 0.0 & 0.02 & $\begin{array}{c}0941 \\
\text { seismic }\end{array}$ & - & - & +436 \\
\hline LO 020 & 0.3 & 0.11 & - & - & - & -12 \\
\hline LO 030 & 4.3 & 0.04 & - & - & - & +233 \\
\hline LO 033 & 6.2 & - & - & $\begin{array}{c}9 \\
\text { superelevation }\end{array}$ & 2,600 & -478 \\
\hline LO 040 & 6.4 & - & $\begin{array}{c}0952 \\
\text { eyewitness }\end{array}$ & $\begin{array}{c}9.6 \\
\text { interpolation }\end{array}$ & 2,000 & -43 \\
\hline NF 100 & 8.1 & - & - & $\begin{array}{c}9 \\
\text { interpolation }\end{array}$ & 3,400 & -191 \\
\hline NF 110 & 10.4 & & & & & -644 \\
\hline NF 113 & & & & & & -772 \\
\hline NF 120 & 14.1 & - & - & - & - & -20 \\
\hline NF 130 & 15.7 & - & $\begin{array}{c}1008 \\
\text { eyewitness }\end{array}$ & $\begin{array}{c}5-7 \\
\text { runup }\end{array}$ & $1,100-1,500$ & -36 \\
\hline NF 300 & 18.6 & - & - & - & - & +64 \\
\hline NF 310 & 21.1 & 0.06 & - & - & - & -225 \\
\hline NF 320 & 22.5 & 0.03 & - & - & - & -16 \\
\hline NF 325 & 23.5 & & $\begin{array}{c}1028 \\
\text { Elk Rock gage }\end{array}$ & - & - & +1 \\
\hline NF 330 & 23.7 & 0.02 & - & - & - & - \\
\hline \multirow[t]{2}{*}{ NF 335} & 24.2 & 0.02 & $\begin{array}{c}1039 \\
\text { (flow front) }\end{array}$ & $\begin{array}{l}2-4 \\
\text { runup, } \\
\text { timed drift }\end{array}$ & - & - \\
\hline & & & $\begin{array}{c}1045 \\
\text { (sediment slug) }\end{array}$ & & & \\
\hline NF 345 & 24.9 & 0.02 & - & - & - & +322 \\
\hline NF 365 & 28.3 & - & 1108 & $\begin{array}{c}2.6 \\
\text { timed drift }\end{array}$ & - & - \\
\hline NF 375 & 29.5 & - & - & - & - & +69 \\
\hline \multicolumn{7}{|l|}{ NF390 } \\
\hline N1 Dam & 33.0 & - & 1138 & $\begin{array}{c}2.3 \\
\text { timed drift }\end{array}$ & - & +113 \\
\hline $\mathrm{NF} 400 \mathrm{~A}$ & 35.5 & - & & - & - & +25 \\
\hline NF 420 & 37.7 & - & 1211 & - & - & -88 \\
\hline
\end{tabular}


(1987) documents erosional features that resulted from a channelized snow avalanche, but other examples of debris flows containing substantial percentages of snow are rare. Although snowy debris flows could exert a significant shear stress on the bed, the substantial scour documented by the cross-section resurveys of channels swept by the May 14 slushflow was probably caused by entrained rock debris and watery recessional flow.

\section{TRANSFORMATION OF DEBRIS FLOW TO HYPERCONCENTRATED FLOW}

Flow transformations in sediment gravity flows have been discussed theoretically by Fisher (1983), and the flow transformations of lahars and the corresponding textural characteristics of their deposits have been documented by field studies (Pierson and Scott, 1985; Scott and Dinehart, 1985; Scott, 1988). The rapid downstream textural changes in May 14 deposits resemble those reported for the March 19, 1982 flows (Pierson and Scott, 1985) in which dilution is inferred to have occurred at the head of the lahar by deposition of solids and incorporation of overrun channel water in a stretch of channel that Scott (1985) called the transition reach (for a given flow).

The transition-reach textural changes in May 14, 1984, deposits were first observed in the bar deposit and basal layer $16 \mathrm{~km}$ from the crater and also $2 \mathrm{~km}$ farther downstream, where the lower unit is better sorted and contains less fine material. Sixteen kilometers from the crater, the bar deposit is poorly sorted and has little evidence of matrix strength (for example, inverse, coarse-tail grading; suspended boulders; floating fragile clasts), unlike the mid-channel diamict deposited in the medial channel environment immediately following deposition of the bars. Because of their stratigraphic relations with the diamict, the bars that are $16 \mathrm{~km}$ from the vent and the lower units 16,18 , and $21 \mathrm{~km}$ from the vent may have been deposited in an environment of turbulent(?) mixing and dilution through incorporation of channel water at the head of the flow. The upper unit that is $21 \mathrm{~km}$ from the vent is texturally similar to hyperconcentrated-flow deposits of March 19, 1982 (Pierson and Scott, 1985); this similarity indicates almost complete transformation from debris flow to hyperconcentrated flow.

Dip samples obtained as the flow passed cross section NF 335 (fig. 6.8) indicate that sediment concentrations were much less than those for debris flows (typically greater than 80 percent by weight for flows that have less than 3 percent clay: Scott, 1988) and that peak sediment concentration lagged the peak discharge by about 5 minutes (fig. 6.16). The peak sediment discharge concentrations of 33 percent solids by weight of a sample obtained at the extreme periphery of the flow probably underestimated sediment concentrations nearer the thalweg where conditions were at least hyperconcentrated.

\section{DRAMATIC WAVE FORMS (HYDRAULIC JUMPS?) OBSERVED IN THE LAHAR RECESSIONAL FLOW}

Hydraulic jumps in rivers have been described as stationary shock waves or surges in which mechanical energy from upstream supercritical flow is abruptly converted to thermal energy through the action of turbulence, such that flow immediately downstream from a jump is deeper and travels at a slower velocity in the subcritical flow regime (Stoker, 1957; Chow, 1959; Komar, 1971). Large, almost evenly-spaced wave forms visible about $16 \mathrm{~km}$ from the crater on May 14 could be hydraulic jumps (figs. 6.5, 6.6). At this location, the hyperconcentrated(?) tail of the lahar apparently returned rapidly to a supercritical state after each successive wave form. This shifting flow state perhaps was caused by (1) an increased velocity due to an increase in slope or confinement by channel narrowing (Baker, 1978; Fisher, 1983), (2) changes in fluid density caused by upward movement of pore fluid due to rapid deposition of large clasts, or (3) increased suspension of fine material because of the turbulence at a hydraulic jump (Middleton and Hampton, 1976; Lowe, 1979) or a combination of these

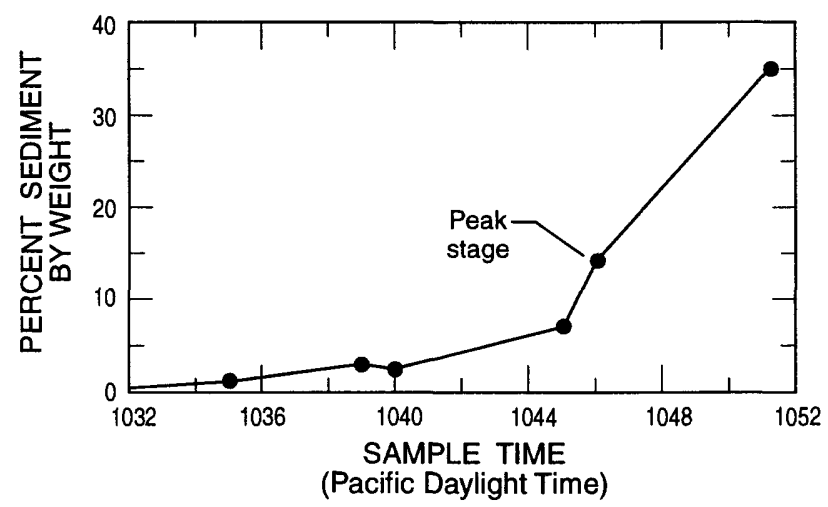

FIGURE 6.16.-Sediment concentration (by weight) changes in a series of dip samples obtained on May 14, 1984, near the periphery of the lahar 24 kilometers from the lava dome (near cross section NF335). 
factors. The regular amplitude of these features suggests that they could have been formed by antidunes; however, no stratigraphic evidence (such as backset beds) was noted (see below).

\section{SCOUR MARKINGS AND DEPOSITIONAL FEATURES OF THE LAHAR}

Sinuous mid-channel bed forms visible in figure 6.7 (moments after the wave forms noted above) seemed to be coarse-grained dunes, but field investigations later revealed only a series of irregularly spaced steps on the surface of the May 14 debris-flow deposit (figs. 6.17, 6.18). These steps, 50 to $80 \mathrm{~m}$ apart, apparently were knickpoints created during recessional flow. The convex upstream shape of several knickpoints in plan view mimicked a similar geometry in some of the wave forms noted in the above section (figs. 6.5, 6.6). These knickpoints may have been scoured by hydraulic jumps, which lasted less than about 30 seconds during passage of a recessional surge.
Numerous active knickpoints observed farther upstream (9-14 km from the vent), just after passage of the lahar, formed when the lahar deposit was being remobilized by recessional flow. Initial reestablishment of the thalweg occurred by removal of the lahar material by turbulent erosion and by corresponding rapidly retreating knickpoints.

Scour markings resulting from the May 14, 1984, lahar occur between the crater floor and $14 \mathrm{~km}$ from the vent. The avalanche/slushflow carved an abraded pavement consisting of grooved, faceted pumice boulders and cobbles in the crater floor. A medial part of upper Steam Creek contained longitudinal streamlined ridges that began downstream of rocks protruding from the underlying deposit (fig. 6.19). Evidence of scour, including flutes and smoothed surfaces of underlying fragmental deposits, were present elsewhere, particularly in areas of the Pumice pond (fig. 6.1) where recessional flow was minimal (see Schmincke, 1967, and Scott 1988). However most of these features were destroyed or buried by talus within a few months of May 14 .

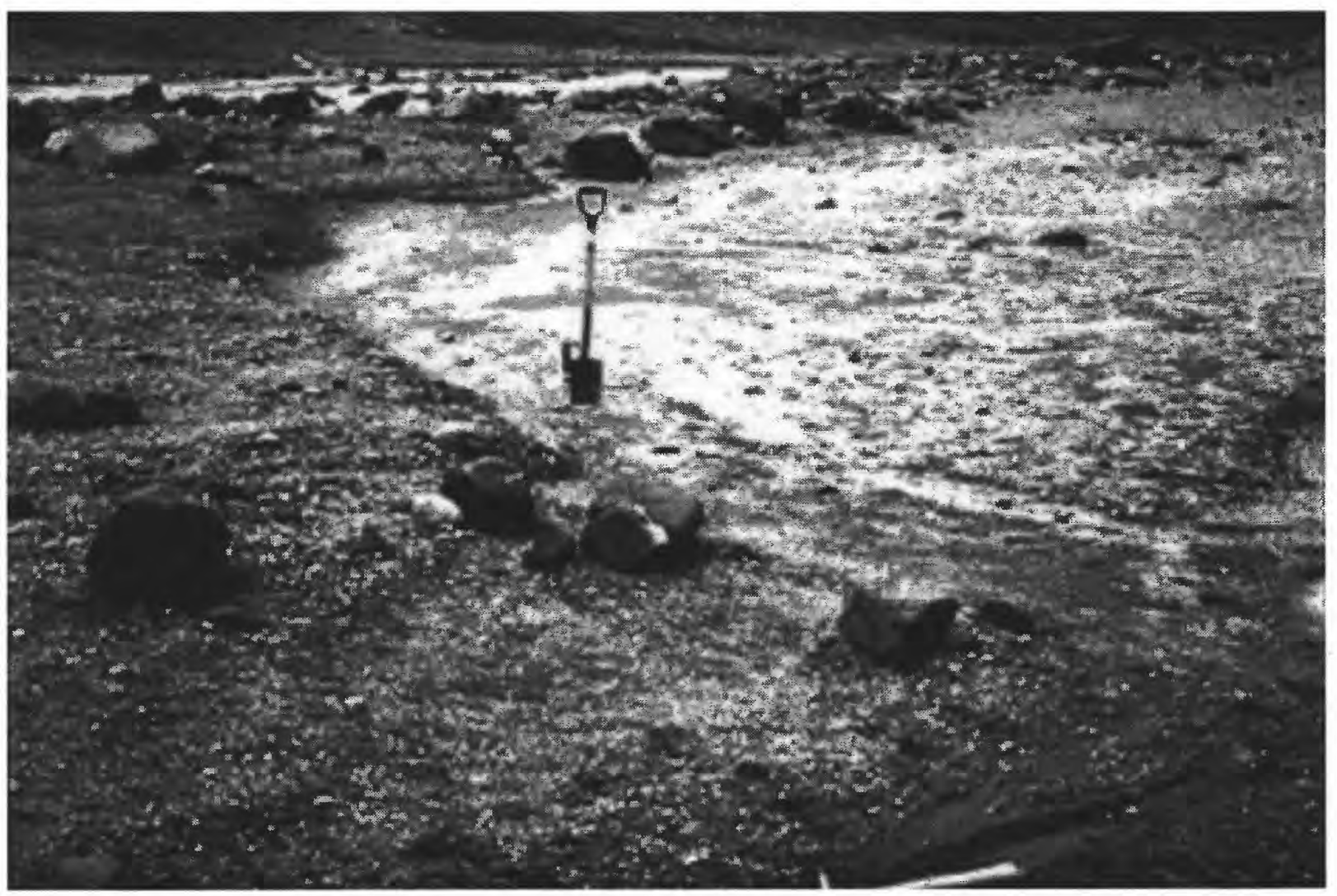

Figure 6.17.-Downstream oblique view of knickpoint cut into debris-flow surface, 16 kilometers from the lava dome. Diffuse boulder levee from debris flow is in the upper-right background. Flow direction is lower left to upper right. Knickpoint was excavated near shovel for diagrammatic cross section shown in figure 6.18. 


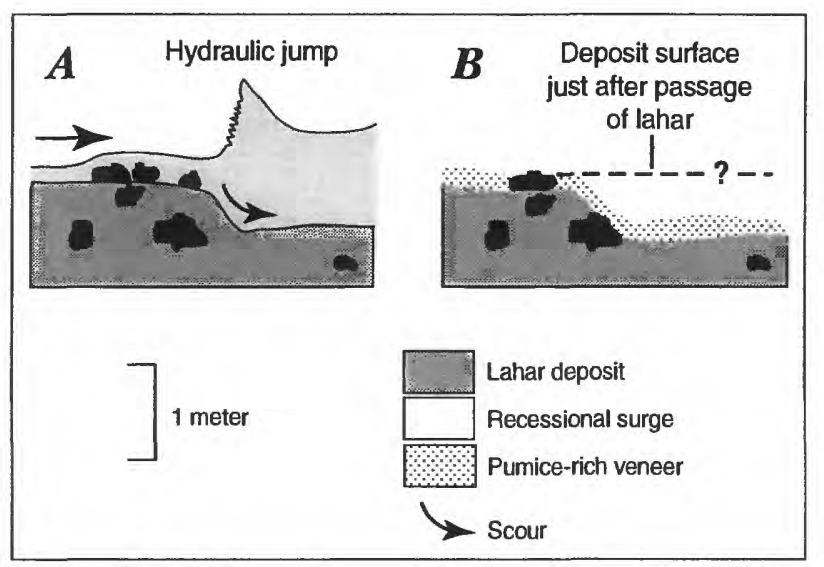

Figure 6.18.-Diagrammatic formation of bed forms in transition reach: $A$. Surging waves and scour during recessional flow on fresh lahar deposit; and $\boldsymbol{B}$. knickpoint bed form (as shown in fig. 6.17) and pumice-rich veneer remaining after tail of lahar drains away.
Fragile clasts, on or within deposits, are evidence of plug flow within a debris flow (Johnson, 1970, p. 513; Enos, 1977). Fragile clasts may include unconsolidated or partly indurated debris and can originate as bankfailure blocks or terrace fragments incorporated by a debris flow. Such clasts (fig. 6.15) are transported more-or-less intact on or near the surface of the rigid plug, and they are commonly preserved in terrace-capping deposits. The downvalley limit of fragile clasts in the May 14 deposits (16 km from the vent) corresponds with the downstream limit of debris-plug deposits. The relative elevation and lateral extent of the fragile clasts within the valley at their downstream limit indicate that the rigid plug was lower in stage than the more-dilute, peak-flow surge, which had deposited the bars immediately before the passage of the debris plug.

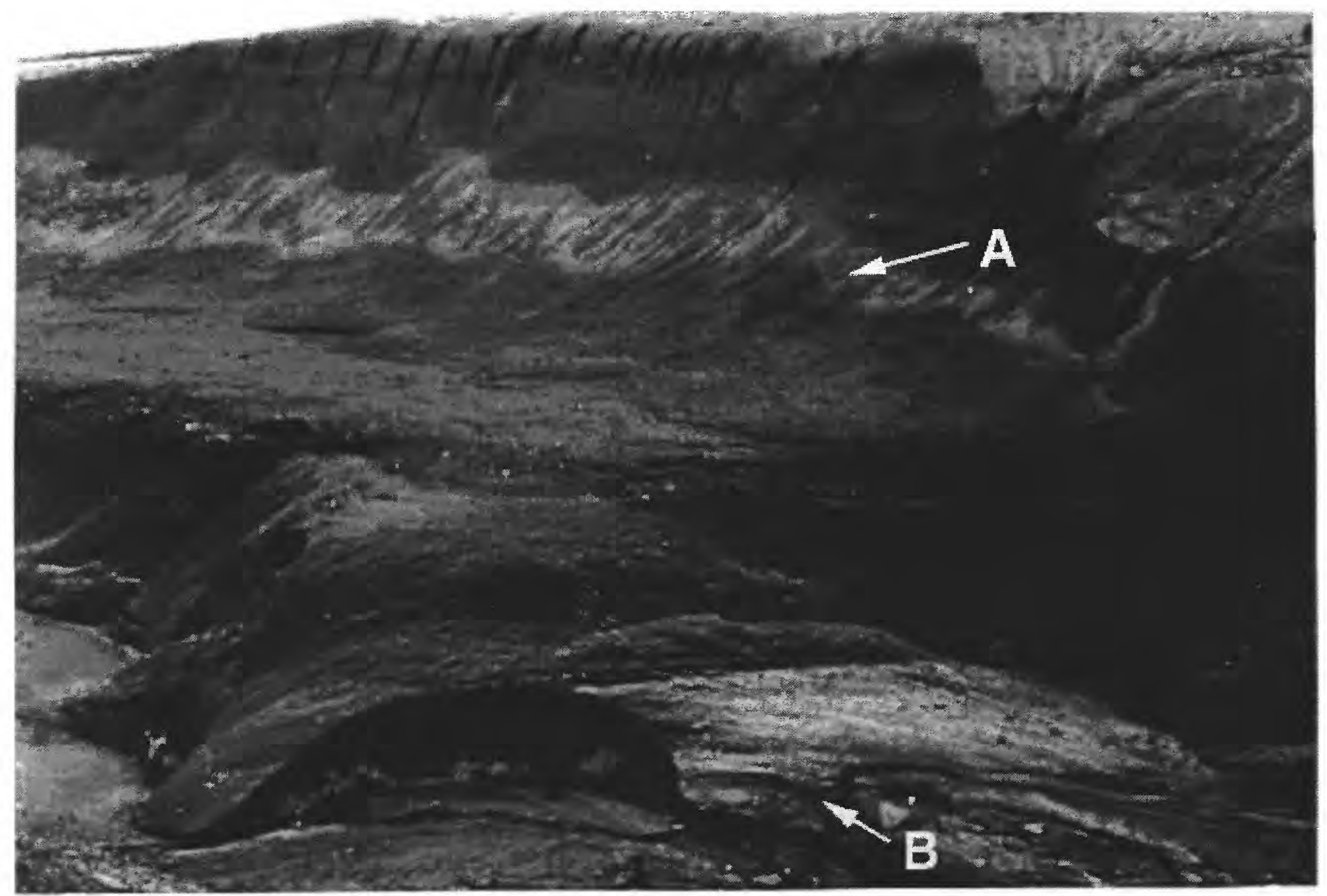

FIGURE 6.19.-Depth of peak flow at mudline $A$. Four kilometers from the lava dome and $\boldsymbol{B}$. Streamlined ridges and smoothed surface scoured by the May 14, 1984, debris flow. Person in lower left corner shows scale. 


\section{POST-LAHAR GEOMORPHIC CHANGES IN THE UPPER NORTH FORK TOUTLE RIVER BASIN}

An earlier study of geomorphic adjustment and development of the drainage system on the 1980 debrisavalanche deposit required the installation of 56 measured cross sections across the North Fork Toutle River and its major tributaries in 1980 and 1981. Most of these cross sections have been surveyed annually using theodolites and electronic distance meters, and a few have been surveyed monthly. Resurveying of several sections soon after May 14 allowed direct measurement of change at about 30 cross sections on the 1980 debris avalanche deposit crossed by the May 14 flow. Six sections were resurveyed on May 15, and 13 more within two months. The general areas of erosion and deposition are easily recognizable from the profile comparisons (fig. 6.20).

Although the avalanche/slushflow was erosive along the crater floor, no significant erosion was caused in the part of Loowit Ravine that is cut into lava flows. Net erosion was documented from 6 to $23 \mathrm{~km}$ from the crater. Incision of more than $5 \mathrm{~m}$ occurred locally, but in some places, notably at cross section LO 033, part of this erosion could be attributed to the action of winter storms before May 14. Recessional-phase erosion 6 to $10 \mathrm{~km}$ from the crater roughly matched erosion during peak flow. Most of the sediment incorporation by the lahar in this reach resulted from slumping of the steep channel walls. Most net erosion 10 to $15 \mathrm{~km}$ from the vent occurred as a result of channel reincisement and sidecutting during recessional flow. This reach had aggraded during the initial stages of the lahar.

In the reach 15 to $21 \mathrm{~km}$ from the vent, where the lahar was transforming from debris flow to hyperconcentrated flow, deposition dominated. As much as $1 \mathrm{~m}$ of material was deposited in near-overbank settings locally; the channel in this reach was not confined, but braided over a width 150 to $250 \mathrm{~m}$. In addition to the dilution caused by overrunning channel water in the North Fork Toutle River and the added water at confluence of Coldwater Creek, spreading of the lahar by channel widening probably contributed greatly to the flow transformation and to the corresponding rapid deposition of material. A short reach of net erosion about $21 \mathrm{~km}$ from the crater may have been the result of a locally steeper gradient.

No substantial channel changes were apparent beyond $23 \mathrm{~km}$ from the crater. The dip samples obtained at cross section NF 335 indicated that the flow had diluted to a concentration close to the boundary between
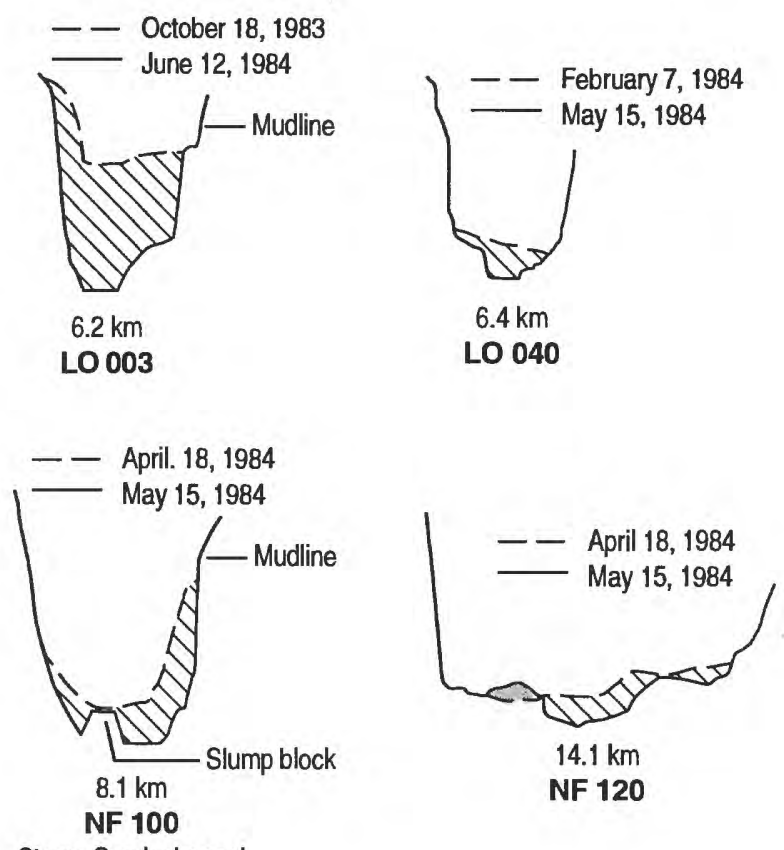

Steam Creek channel
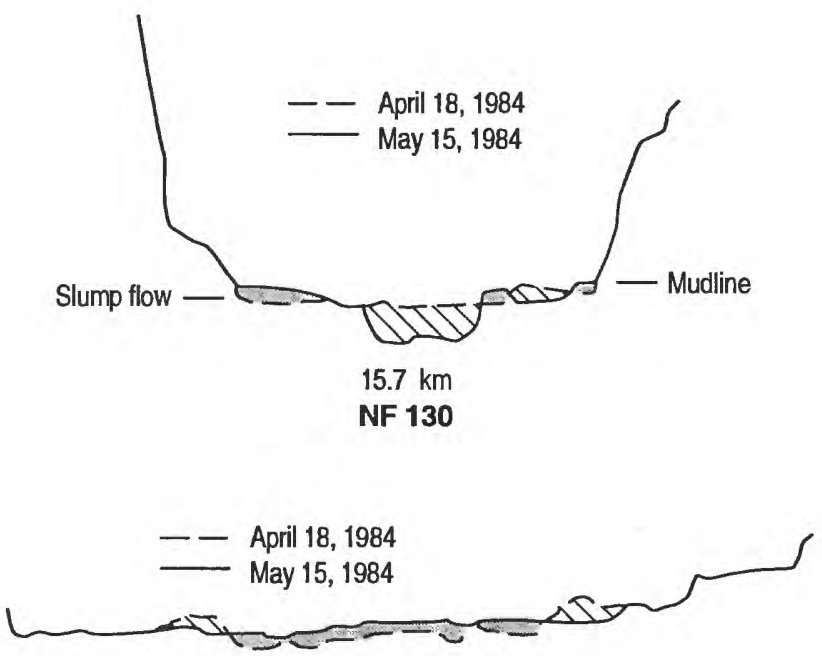

$18.6 \mathrm{~km}$

NF $\mathbf{3 0 0}$
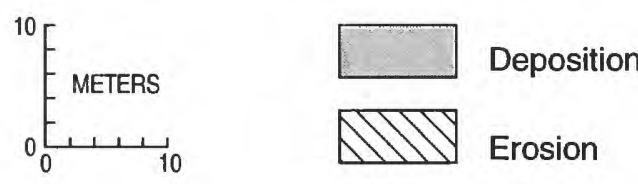

FIGURE 6.20.-Selected cross-section plots of the North Fork Toutle River basin showing net erosion and deposition caused by the May 14, 1984, lahar. Channel distance from the lava dome is shown above each cross-section number. 
hyperconcentrated flow and muddy flood. Nevertheless, considerable coarse bedload transport occurred for at least one hour after the flow front had passed the Elk Rock area, indicated by the prolonged, high-frequency seismic signal from the Elk Rock seismograph (ERT) (fig. 6.21). Generally, less than $0.5 \mathrm{~m}$ of deposition occurred along the channel between Elk Rock and the Toutle Dam (N-1 sediment dam, 23-33 km downstream from the vent) and in the upper reach of the Bear Creek channel. No significant changes attributable to the flow were seen downstream of the Toutle Dam.

\section{SUMMARY}

On May 14, 1984, a shallow-seated explosion from the dome at Mount St. Helens sprayed the west crater wall with hot rock debris and gases and triggered a mixed snow-and-rock avalanche and slushflow that exited the crater through the Breach into upper Loowit Ravine. This mixture transformed into a debris flow on the Pumice Plain as it accumulated sediment and heat from the still-hot 1980 pyroclastic flow deposits and added water through melting of admixed snow and ice granules and through incorporation of water from stream channels and saturated sediments. The resulting debris flow was erosional throughout the Pumice Plain but caused aggradation of the active channel of the North Fork Toutle River from 8 to $16 \mathrm{~km}$ from the lava dome before transforming to a hyperconcentrated flow.

This report documents an unusual geologic opportunity, that of making eyewitness observations of a relatively small lahar at close range and then of subsequently examining the lahar deposits and geomorphic effects of its passage. This may be the first report in which observed flow transformations in a lahar

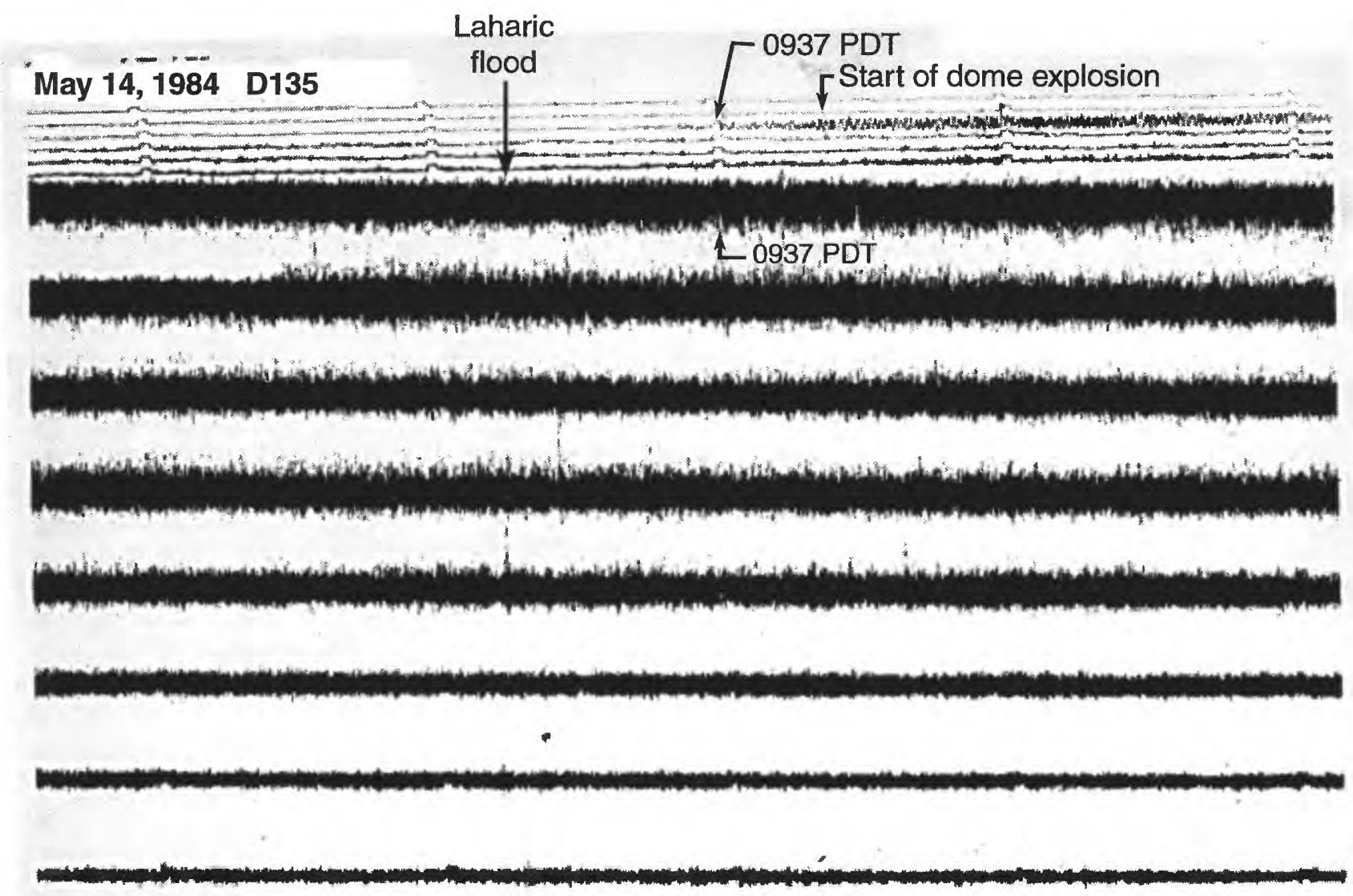

Figure 6.21. - Section of a seismogram from the Elk Rock Three seismograph (ERT), located about 24 kilometers downstream of the vent near the North Fork Toutle River. Elongated, high frequency seismic signal shows passage of the May 14, 1984 lahar. Each horizontal line is separated by 15 minutes; 1 -minute tic marks (small square humps) are visible in the top six lines. 
have been correlated with downstream textural changes in its deposits.

Temporal and downstream changes in the flow behavior and correlative textural changes in deposits were documented by eyewitness observations, velocity measurements, sampling of the lahar, and examination of deposits after they became exposed. At least $7.1 \times 10^{10}$ joules were required to generate the estimated $4 \times 10^{5}$ cubic meters of meltwater incorporated in the lahar from crater snow and ice.

\section{ACKNOWLEDGMENTS}

The authors thank K.M. Scott, D.W. Hubbell, and Martha Crawford for reviews of this manuscript. R.M. Iverson, K. M. Nolan, and J.E. O'Connor also had helpful comments on the text. We shared enthusiastic discussions about the May 14 explosion, lahar, and related processes and deposits with R.J. Janda (deceased), T.C. Pierson, D.F. Meyer, R.L Shreve, R.B. Waitt, Peter Otway, R.V. Fisher, P.M. Mango, W.W. Mast, M.P. Doukas, T.J. Casadevall, Lyn Topinka, Bobbie Myers and various staff members of the Cascades Volcano Observatory. Helicopter pilot Bob Edwards deftly flew us along side the actively flowing lahar and to downstream locations where we warned tourists and construction personnel about the approaching flood.

\section{REFERENCED CITED}

Ackroyd, Peter, 1987, Erosion by snow avalanche and implications for geomorphic stability, Torlesse Range, New Zealand: Arctic and Alpine Research, v. 19, p. 65-70.

Baker, V.R., 1978, Paleohydraulics and hydrodynamics of Scabland floods, in Baker, V.R., and Nummedal, P., eds, The Channeled Scabland: Washington, D.C., National Aeronautics and Space Administration, p. 59-79.

Beverage, J.P., and Culbertson, J.K., 1964, Hyperconcentrations of suspended sediment: American Society of Civil Engineers Proceedings, Journal of the Hydraulics Division, v. 90, no. HY6, pt. 1, p. 117-128.

Blackwelder, Eliot, 1928, Mudflow as a geologic agent in semiarid mountains [with a discussion by J.T. Singewald, Jr.]: Geological Society of America Bulletin, v. 39, no. 2, p. 465-484.

Chow, V.T., 1959, Open-channel hydraulics: New York, McGraw Hill, 680 p.

Costa, J.E., and Williams, G.P., 1984, Debris-flow dynamics (videotape): U.S. Geological Survey Open-File Report 84-606, 22 minutes. [Available only at U.S. Geological Survey Training Center, Denver Federal Center, Mail Stop 414, Denver, Colorado 80225]
Crandell, D.R., 1971, Postglacial lahars from Mount Rainier volcano, Washington: U.S. Geological Survey Professional Paper 677, $75 \mathrm{p}$.

Enos, P., 1977, Flow regimes in debris flow: Sedimentology, v. 24 , no. 1 , p. 133-142.

Fisher, R.V., 1983, Flow transformations in sediment gravity flows: Geology, v. 11, no. 5, p. 273-274.

Folk, R.L., 1974, Petrology of sedimentary rocks (2nd ed.): Austin, Hemphill's, 182 p.

Janda, R.J., Scott, K.M., Nolan, K.M., and Martinson, H.A., 1981, Lahar movement, effects, and deposits, in Lipman, P.W., and Mullineaux, D.R., eds., The 1980 eruptions of Mount St. Helens, Washington: U.S. Geological Survey Professional Paper 1250, p. 461-478.

Johnson, A.M., 1970, Physical processes in geology, a method for interpretation of natural phenomena, intrusions in igneous rocks, fractures, and folds; flow of debris and ice: San Francisco, Freeman Cooper, 577 p.

Kochel, R.C., and Baker, V.R., 1982, Paleoflood hydrology: Science, v. 215, no. 4531, p. 353-361.

Komar, P.D., 1971, Hydraulic jumps in turbidity currents: Geological Society of America Bulletin, v. 82, no. 6, p. 1477-1487.

Lowe, D.R., 1979, Sediment gravity flows-Their classification and some problems of application to natural flows and deposits, in Doyle, L.J., and Pilkey, O.H., eds., Geology of continental slopes: Society of Economic Paleontologists and Mineralogists Special Publication 27, p. 75-82.

Middleton, G.V., and Hampton, M.A., 1973, Sediment gravity flows: Mechanics of flow and deposition, in Turbidites and deep-water sedimentation: Los Angeles, Society of Economic Paleontologists and Mineralogists, Pacific section, p. 1-38.

Middleton, G.V., and Hampton, M.A., 1976, Subaqueous sediment transport and depostion by sediment gravity flows, in Stanley, D.J., and Swift, D.J.P., eds., Marine sediment transport and environmental management: John Wiley and Sons, Inc., p. 197-218.

Patton, P.C., Baker, V.R., and Kochel, R.C., 1979, Slack-water deposits-A geomorphic technique for the interpretation of fluvial paleohydrology, in Rhodes, D.D., and Williams, G.P., eds., Adjustments of the fluvial system; tenth annual geomorphology symposium: Dubuque, Iowa, Kendall/Hunt, p. 225-253.

Pierson, T.C., 1980, Erosion and deposition by debris flows at Mt. Thomas, North Canterbury, New Zealand: Earth Surface Processes, v. 5, no. 3, p. 227-247.

Pierson, T.C., and Scott, K.M., 1985, Downstream dilution of a lahar; transition from debris flow to hyperconcentrated streamflow: Water Resources Research, v. 21, p. 15111524. 
Pierson, T.C, and Costa, J.E., 1987, A rheologic classification of subaerial sediment-water flows: Geological Society of America Reviews in Engineering Geology, v. VII, p. 1-12.

Schmincke, H.-U., 1967, Graded lahars in the type sections of the Ellensburg Formation, south-central Washington: Journal of Sedimentary Petrology, v. 37, no. 2, p. 438-448.

Scott, K.M., 1985, Lahars and flow transformations at Mount St. Helens, Washington, U.S.A., in International symposium on erosion, debris flows, and disaster prevention: Tsukuba, Japan, p. 209-214.

Scott, K.M., 1988, Origins, behavior, and sedimentology of lahars and lahar runout flows in the Toutle-Cowlitz River system, Mount St. Helens, Washington: U.S. Geological Survey Professional Paper 1447-A, 74 p.

Scott, K.M., and Dinehart, R.L., 1985, Sediment transport and deposit characteristics of hyperconcentrated streamflow evolved from lahars at Mount St. Helens, Washington, in Proceedings, International Workshop on Flow at Hyperconcentrations of Sediment: Sept. 10-14, Beijing, China, 1985, Proceedings, $33 \mathrm{p}$.
Sharp, R.P., and Nobles, L.H., 1953, Mudflow of 1941 at Wrightwood, southern California: Geological Society of America Bulletin, v. 64, no. 5, p. 547-560.

Smith, G.A., and Lowe, D.R., 1991, Lahars: Volcanohydrologic events and deposition in the debris flowhyperconcentrated flow continuum, in Fisher, R.V., and Smith, G.A., eds., Sedimentation in volcanic settings: SEPM (Society for Sedimentary Geology) Special Publication 45, p. 59-70.

Stoker, J.J., 1957, Water waves; the mathematical theory with applications: Wiley Interscience Publishers, 567 p.

U.S. Army Corps of Engineers, 1984, Alternative strategies for a permanent outlet for Spirit Lake near Mount St. Helens, Washington; final environmental impact statement: [Portland, Oregon], 1 v., various paging.

Waitt, R.B., Jr., Pierson, T.C., MacLeod, N.C., Janda, R.J., Voight, Barry, and Holcomb, R.T., 1983, Eruptiontriggered avalanche, flood, and lahar at Mount St. HelensEffects of winter snowpack: Science, v. 221, no. 4618, p. 1394-1397. 
$-104-$

APPENDIXES 1.A AND 1.B 
(Page 109 TO FOLLOW)

APPENDIX 1.A 


\section{APPENDIX 1.A - ANALYSIS}

I examine here the physics of heat flow from a pyroclastic deposit to subjacent snow or ice, with the goal of determining whether irregularities at the interface will be amplified or muted by heterogeneities in heat flux. The mean thickness $\mathrm{L}$ of the deposit is assumed small compared to its lateral extent, so that for mathematical purposes the layer may be considered of infinite extent. The analysis is restricted to the case of small-amplitude irregularities. The large-amplitude case is not amenable to analysis, although it would be straightforward to use a finite-element numerical approach. Because the object here is to elucidate physical principles rather than tabulate numerical results of uncertain applicability, such a computational effort does not seem appropriate.

The coordinate system is shown in figure 1.A1. It is useful, although not necessary, to think of the contact as having been scoured by the pyroclastic flow before the flow came to rest; the cross section of figure 1.A1 is then normal to the flow direction. As the substrate melts, the entire deposit moves downwards relative to fixed coordinates. The rate of motion of the contact will be constrained by thermodynamics because the contact represents a phase change from ice to water or vapor. The aim here is to determine the spatial variability in that rate of motion and thus whether irregularities on the contact grow or decay.

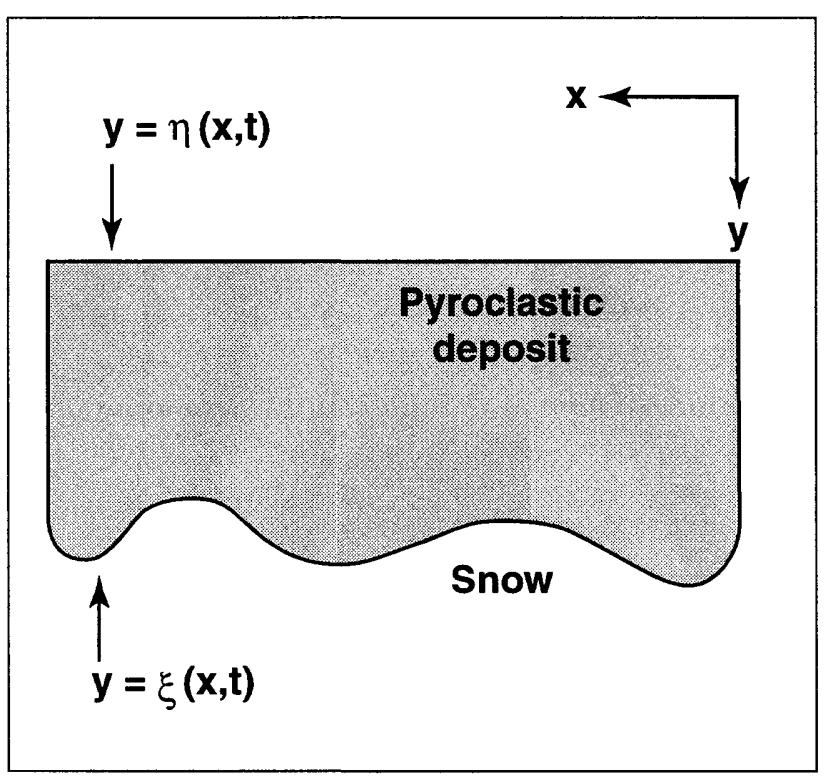

FigURE 1.A.1.-Definition of coordinate system for heat-flow analysis.
I assume that heat transfer within the pyroclastic deposit is purely conductive; thus advective heat transfer by gases within the deposit's pores, and in particular, by water vapor generated at the deposit's base, is ignored. This assumption certainly fails if the substrate consists of glacier ice or firn, in which case meltwater will not be able to escape readily. Ponded water at the contact might reasonably be expected to vaporize due to its proximity to hot pyroclastic material, and then to escape upward through the deposit. A similar phenomenon should occur even with a permeable snow substrate if the pyroclasts are hot enough. Although the detailed physics of heat transfer from a hot deposit to a frozen substrate are still not well understood, by drawing analogy to results from studies of boiling (Whitaker, 1977), I suggest that pyroclastic grains will generally be separated from the frozen substrate by a fluid film across which heat is transferred. Meltwater flows along this film towards the nearest pore, gaining heat from the pyroclasts along the way. If the pyroclast temperature $T_{\mathrm{d}}$ exceeds some critical value $T_{\text {crit }}$, the meltwater will vaporize before it can reach the pore. The water vapor so generated will then tend to escape upward through the pyroclastic deposit. On the other hand, if $T_{\mathrm{d}}<T_{\text {crit }}$, the meltwater will remain liquid and tend to percolate downward into the snow, quickly losing its excess sensible heat by melting more snow.

If meltwater produced at the base of the pyroclastic deposit does vaporize and escape upward, cooling of the pyroclastic deposit would no longer be simply by conduction; advective heat transport by the vapor and thermal interaction between the vapor and the solid grains would have to be explicitly considered (Baer and Nunziato, 1986). Based on preliminary results of experiments (Walder, 1992, 1995), I suggest $T_{\text {crit }} \approx 200^{\circ} \mathrm{C}$, so advective heat transport is in fact likely to be significant in many cases. However, as explained later, this will have no qualitative effect on conclusion drawn from the purely conductive model, so for simplicity I ignore advection.

The mathematical problem to be posed is in the general class of moving-boundary problems (Carslaw and Jaeger, 1959, p. 282-296). The temperature $T$ in the deposit is described by the equation

$$
\frac{\partial T}{\partial t}+\vec{u} \bullet \nabla T=\kappa\left(\frac{\partial^{2} T}{\partial \mathrm{x}^{2}}+\frac{\partial^{2} T}{\partial \mathrm{y}^{2}}\right),
$$

where $\mathrm{\kappa}=k_{\mathrm{p}} / \rho_{\mathrm{p}} c_{\mathrm{p}}$ is the thermal diffusivity of the deposit, with $k_{\mathrm{p}}$ its thermal conductivity, $\rho_{\mathrm{p}}$ its density, and $c_{\mathrm{p}}$ its specific heat; $\vec{u}$ is the particle velocity, $x$ and $y$ are 
spatial coordinates, and $t$ is time. The initial condition is simply

$$
T(t=0)+T_{\mathrm{d}}
$$

for $\eta(x, t) \leq y \leq \xi(x, t)$.

The appropriate boundary conditions are less obvious. For plausible terrestrial conditions, the substrate (snow or ice) will exist near its melting point $T_{\mathrm{m}}$ and must be melted by the much hotter pyroclasts. In line with earlier discussion in this appendix, temperature in the fluid film between pyroclasts and ice grains may vary tremendously on a short length scale, being as low as $T_{\mathrm{m}}$ or as great as, and perhaps greater than, the vapor point $T_{\mathrm{v}}$. Lacking experimental data, one can state only that the average temperature $T_{\mathrm{b}}$ at the base of the pyroclastic deposit is bounded by $T_{\mathrm{b}} \geq T_{\mathrm{m}}$, and that as the deposit cools, $T_{\mathrm{b}} \rightarrow T_{\mathrm{m}}$. For purposes of the present analysis, I will therefore make the physically reasonable assumption that $T_{\mathrm{b}}$ relaxes exponentially from an initial value of $T_{\mathrm{d}}$ toward the melting point:

$$
T(y=\xi(x, t))=T_{\mathrm{b}}=T_{\mathrm{m}}+\left(T_{\mathrm{d}}-T_{\mathrm{m}}\right) e^{-\beta t},
$$

where $\beta$ is the reciprocal of the time scale over which the boundary temperature relaxes to that of the substrate; $1 / \beta$ is sensibly much less than the characteristic time scale for the bulk of the deposit to cool substantially. (In other words, the base of the deposit approaches a temperature of $T_{\mathrm{m}}$ much more quickly than does the bulk of the deposit). Henceforth $\mathrm{I}$ take $T_{\mathrm{m}}=0$. The detailed form of the lower boundary condition, as long as it reflects the physical necessity that the temperature relaxes toward $T_{\mathrm{m}}$ over a finite period of time, has no effect on the conclusions as to growth or decay of irregularities.

The appropriate boundary condition to apply at the free surface $y=\eta(x, t)$ also requires careful consideration. Air is a poor conductor of heat, and heat loss from the free surface is probably dominated by convection due to wind and perhaps due to escaping vapor as well. A boundary condition of the form used by Ryan and others (1990), namely, $T[y=\eta(x, t)]=T_{\mathrm{a}}$, where $T_{\mathrm{a}}$ is the air temperature, will tend to overestimate heat loss to the atmosphere. Proper description of the convective boundary condition at $y=\eta(x, t)$ would require specification of at least air temperature and wind speed [see any text on heat transfer, for example, Whitaker (1977)]. In light of the uncertainties, for mathematical simplicity I will assume the upper boundary to be insulated:

$$
\frac{\partial T}{\partial n}(y=\eta(x, t))=0,
$$

where $\partial T / \partial n$ is the normal derivative, nearly equal to $\partial T / \partial y$ if the free surface is relatively smooth $(|\partial \eta / \partial x| \ll 1)$. This assumption leads to an overestimate of total heat loss from the base, but has no effect on the qualitative conclusions regarding growth or decay of contact irregularities.

Some justification for using equation (1.A4) comes from recent observations made at Mt. Redoubt, Alaska, by Edward Wolfe and Cynthia Gardner (oral communication, 1990), who examined a pyroclastic deposit that had been laid down on snow only a few hours previously. The deposit, roughly $0.5 \mathrm{~m}$ thick, was cold - in fact, partially frozen-at its base, yet hot and dry at its surface, indicating that heat was removed from the base of the deposit much more efficiently than from the free surface.

The existence of a moving boundary requires that one more boundary condition be specified, namely, that which relates the rate of motion of the contact $\xi(x, t)$ to the heat flux at the contact. To do so, I will assume that as the deposit melts its way downward, particles move strictly vertically. Thus, the only non-zero component of $u_{h}$ is the $\mathrm{y}$-component, denoted by $v$. Further assuming that the density of the deposit remains constant, it follows that

$$
v=v(x, t)=\frac{\partial \xi}{\partial t} .
$$

The heat-flux condition at the contact is then

$$
\rho_{\mathrm{i}}(1-\phi) H \frac{\partial \xi}{\partial t}=-k_{\mathrm{p}} \frac{\partial T}{\partial y} \text { on } y=\xi(x, t) .
$$

where $\rho_{i}$ is the density of ice, $\phi$ is the snow's porosity, and $H$ is the latent heat of melting. Equation (1.A6) expresses the rate of movement of the contact due to melting. In general, the moving-boundary condition (equation 1.A6) renders equation 1.A1 nonlinear, because $v$ depends on $\partial T / \partial y$. As will be shown below, however, under appropriate constraints the problem effectively linearizes.

In order to discuss the evolution of topography on the moving boundary $\xi(x, t)$, a mean boundary and local 
deviations therefrom need to be defined. Formally one may write

$$
\bar{\xi}(t)=\lim _{D \rightarrow \infty} \frac{1}{2 D} \int_{-D}^{D} \xi(x, t) d x,
$$

and similarly

$$
\bar{\eta}(t)=\lim _{D \rightarrow \infty} \frac{1}{2 D} \int_{-D}^{D} \eta(x, t) d x,
$$

as long as $\xi(x, t)$ and $\eta(x, t)$ are themselves finite for all $x$. The mean speed of the contact is then simply

$$
\bar{v}(t)=\frac{d \bar{\xi}}{d t} .
$$

It is now straightforward to transform the coordinate system to one that moves with the mean boundary $\bar{\xi}(t)$ by choosing

$$
y^{*}=y-\bar{\xi}(t)+L,
$$

where $L$ is the mean thickness of the deposit, that is,

$$
L=\bar{\xi}-\bar{\eta}=\lim _{D \rightarrow \infty} \frac{1}{2 D} \int_{-D}^{D}[\xi(x, t)-\eta(x, t)] d x,(
$$

whence (1.A1) may be rewritten as

$$
\frac{\partial T}{\partial t}+(v-\bar{v}) \frac{\partial T}{\partial y^{*}}=\kappa\left(\frac{\partial^{2} T}{\partial x^{2}}+\frac{\partial^{2} T}{\partial y^{* 2}}\right),
$$

with the initial condition

$$
T(t=0)=T_{\mathrm{d}} \text { for } \eta-\eta \leq \xi-\bar{\xi}+L,
$$

and the boundary conditions

$$
\begin{gathered}
T_{\mathrm{d}} e^{-\beta \mathrm{t}} \text { on } y^{*}=\xi-\bar{\xi}+L \\
\frac{\partial T}{\partial n}=0 \text { on } y^{*}=\eta-\bar{\eta} \\
\rho_{\mathrm{i}}(1-\phi) H \frac{\partial \xi}{\partial t}=-k_{\mathrm{p}} \frac{\partial T}{\partial y^{*}} \text { on } y^{*}=\xi-\bar{\xi}+L,\left(1,{ }^{2},\right.
\end{gathered}
$$

For purposes of further analysis, I recast equation 1.A12 into dimensionless form, using

$$
\begin{aligned}
x & =\lambda X \\
y^{*} & =L Y \\
t & =\left(L^{2} / \kappa\right) \tau \\
T & =T_{\mathrm{d}} \theta
\end{aligned}
$$

where $\lambda$ is the characteristic length scale over which the deposit thickness varies in the $x$ direction. The characteristic velocity scale $v_{\text {char }}$ is sensibly given by $l_{\mathrm{m}} /\left(L^{2} / \kappa\right)$, thus using equation (1.1) of the main text,

$$
v_{\text {char }}=\frac{k_{\mathrm{p}} T_{\mathrm{d}} / L}{\phi \rho_{\mathrm{i}} H},
$$

whence equation $1 . A 12$ becomes

$$
\frac{\partial \theta}{\partial \tau}+N_{\mathrm{a}}(\nu-\bar{v}) \frac{\partial \theta}{\partial Y}=\mu^{2} \frac{\partial^{2} \theta}{\partial X^{2}}+\frac{\partial^{2} \theta}{\partial Y^{2}},
$$

where $v$ and $\bar{v}$ are dimensionless velocity and mean velocity, respectively, both $O(1) ; \mu=L / \lambda$, and

$$
N_{\mathrm{a}}=\left(\frac{c_{\mathrm{p}} T_{\mathrm{d}}}{H}\right)\left(\frac{\rho_{\mathrm{p}}}{\phi \rho_{\mathrm{i}}}\right)
$$

is a dimensionless number indicating the relative importance of the advective term in the energy balance. Taking parameter values as in the main text, one can estimate $N_{\mathrm{a}} \approx 4-10$; accordingly, the advective term is negligible and the mathematical problem linearizes only if $v-\bar{v} \ll 1$. Conditions under which this approximation holds will now be elucidated.

Suppose that the contact roughness is described by an equation of the form

$$
\xi-\bar{\xi}=\delta L \operatorname{sink}_{\xi} x,
$$

where $k_{\xi}=2 \pi / \lambda_{\xi}$, with $\lambda_{\xi}$ the wavelength of the contact irregularities. Similarly, assume that the free-surface topography is given by

$$
\eta-\bar{\eta}=\varepsilon L \operatorname{sink}_{\eta} x
$$

where $k_{\eta}=2 \pi / \lambda_{\eta}$, with $\lambda_{\eta}$ the wavelength of free-surface irregularities. Because my purpose here is to determine simply how variations in deposit thickness affect the local melt rate at the contact with the underlying snow, I can without loss of generality take the free surface as planar. This simplifies the mathematics without affecting the qualitative result. Thus, I take $\eta=\bar{\eta}, k_{\xi}=k, \lambda_{\xi}=\lambda$. Evidently, $v-\bar{v} \rightarrow 0$ as $\xi-\bar{\xi} \rightarrow 0$ because the melt rate must be uniform on a planar boundary. Therefore $v-\bar{v}-O(\delta)$, and in particular,

$$
v-\bar{v} \approx \delta \bar{v} \text { as } \delta \rightarrow 0 .
$$

Accordingly, for small-amplitude irregularities $(|\delta \ll 1|)$, the advective term on the left-hand side of equation 1. A19 vanishes and the problem linearizes.

The mathematical problem to be solved is thus, in dimensionless form, 


$$
\frac{\partial \theta}{\partial \tau}=\mu^{2} \frac{\partial^{2} \theta}{\partial X^{2}}+\frac{\partial^{2} \theta}{\partial Y^{2}}
$$

with the initial condition

$$
\theta(\tau=0)=1 \text { for } 0 \leq Y \leq \Xi(X),
$$

and the boundary conditions

$$
\begin{gathered}
\theta=e^{-\gamma \tau} \text { on } Y=\Xi(X), \\
\frac{\partial \theta}{\partial n}=0 \text { on } Y=0,
\end{gathered}
$$

where $\gamma=\beta L^{2} / \kappa(\gg 1)$ and

$$
\Xi(X)=1+\delta \sin 2 \pi X .
$$

The flux boundary condition, expressed in dimensionless form as

$$
v=-\frac{\partial \theta}{\partial Y} \text { on } Y=\Xi(X),
$$

now simply serves to provide an a posteriori means of calculating the speed at which the contact moves. Peaks on the contact correspond to $\sin 2 \pi X<0$, troughs to $\sin 2 \pi X>0$.

The assumption of small-amplitude irregularities $(|\delta \ll 1|)$ means that the boundary condition applied on the wavy contact can be expanded using a Taylor series as

$\theta[Y=\Xi(X)]=\theta(Y=1)+\delta \sin 2 \pi X \frac{\partial \theta}{\partial Y}(Y=1)+O\left(\delta^{2}\right)$,

thereby in effect transferring the boundary condition to the plane $Y=1$. The form of equation 1.A30 suggests (Carrier and Pearson, 1976) a perturbation scheme of the form

$$
\theta(X, Y, \tau ; \mu)=\theta^{(0)}(Y, \tau)+\delta \theta^{(1)}(X, Y, \tau ; \mu)+O\left(\delta^{2}\right),
$$

where $\theta^{(0)}(Y, \tau)$ is simply the (dimensionless) temperature distribution for the limiting case of planar boundaries. The dimensionless temperature gradient at the contact may therefore be expressed as

$$
\begin{aligned}
& \frac{\partial \theta}{\partial Y}[Y=\Xi(X)]=\frac{\partial \theta^{(0)}}{\partial Y}(Y=1)+\delta\left[\frac{\partial \theta^{(1)}}{\partial Y}(Y=1)\right. \\
& \left.+\sin 2 \pi X \frac{\partial \theta^{(0)}}{\partial Y}(Y=1)\right]+O\left(\delta^{2}\right),
\end{aligned}
$$

which is the quantity of eventual interest, as it is proportional to the melt rate and thus determines whether irregularities on the contact will grow or shrink.

Using equation 1.A31 in equations $1 . A 24$ through $1 . A 27$ and separating terms of like order, one finds for the leading-order terms

$$
\frac{\partial \theta^{(0)}}{\partial \tau}=\frac{\partial^{2} \theta^{(0)}}{\partial Y^{2}}
$$

with the conditions

$$
\begin{gathered}
\theta^{(0)}(0 \leq Y \leq 1, \tau=0)=1, \\
\theta^{(0)}(Y=1, \tau)=e^{-\gamma \tau}, \\
\frac{\partial \theta^{(0)}}{\partial Y}(Y=0, \tau)=0
\end{gathered}
$$

and for the $O(\delta)$ terms,

$$
\frac{\partial \theta^{(1)}}{\partial \tau}=\mu^{2} \frac{\partial^{2} \theta^{(1)}}{\partial X^{2}}+\frac{\partial^{2} \theta^{(1)}}{\partial Y^{2}},
$$

with the conditions

$$
\begin{gathered}
\theta^{(1)}(0 \leq Y \leq 1, \tau=0)=0, \\
\theta^{(1)}(Y=1, \xi, \tau)=-\sin 2 \pi X \frac{\partial \theta^{(0)}}{\partial Y}(Y=1)+O\left(\delta^{2}\right), \\
\frac{\partial \theta^{(1)}}{\partial Y}(Y=0, \tau)=0
\end{gathered}
$$

The lower boundary condition reflects the additional assumption that irregularities at the contact not only have small amplitude but also small slope, that is, $\xi(=\mu \delta)$, in which case $\partial \theta / \partial n=\partial \theta / \partial Y$ to within $O\left(\xi^{2}\right)$. This assumption simplifies the algebra without qualitatively altering the results.

Exact expressions for $\theta^{(0)}$ and $\theta^{(1)}$ may readily be found by the Laplace-transform method (Carslaw and Jaeger, 1959). Solution by this method involves transform pairs that are not tabulated, so explicit inversion of the transforms requires evaluating contour integrals in the complex plane. Details are given in Appendix B. The quantity of principal interest here is $Q$, the heat flux at the contact $Y=\Xi(X)$ integrated over time, given in dimensionless terms as

$$
Q=-\int_{0}^{\infty} \frac{\partial \theta}{\partial Y}[Y=\Xi(X)] d t .
$$


Using equation 1.A33 and the results in Appendix 1.B, I find

$$
Q=1-\delta(-1+2 \pi \mu) \sin 2 \pi X+O\left(\delta^{2}\right),
$$

where the first term on the right-hand side of equation 1.A42 is simply the mean heat flux. Equation 1.A42 shows that peaks on the contact receive a greater flux than troughs-and thus irregularities tend to be damped-if $2 \pi \mu>1$, that is, for irregularities with wavelength $\lambda<2 \pi L$. In contrast, long-wavelength irregularities $(\lambda>2 \pi L)$ tend to be enhanced by melting. For a pyroclastic deposit with a thickness of, say, a few tens of $\mathrm{cm}$ (as in figure 1.1A), irregularities that have wavelengths less than about $1 \mathrm{~m}$ would tend to be damped. Small-scale "scour" features, should they in fact ever exist, are thus likely to be muted or destroyed by the time an observer can arrive on the scene.

A final comment about heat advection by vapor, heretofore neglected in the analysis, is in order. Considering again figure 1.A1, for short-wavelength irregularities, the conductive heat flux to the snow at the trough $A$ is less than at the peak $B$; accordingly, the melt rate, and thus (if the base of the deposit is hot enough) the vaporization rate, is less at $A$ than at $B$. Because the vapor will tend to rise vertically and convectively cool the deposit as it rises (the vapor itself becoming superheated), the deposit above A will undergo less convective cooling than the deposit above $\mathrm{B}$. The vapor flux therefore tends to keep the deposit above A hotter than the deposit above $B$, reinforcing the tendency for conduction to divert heat from A toward B. For longwavelength irregularities, $A$ and $B$ are, as before, effectively thermally isolated from each other. 
(Page 117 TO FOLLOW)
(P)

APPENDIX 1.B 


\section{APPENDIX 1.B-INVERSION OF LAPLACE TRANSFORM}

The Laplace transform is particularly appropriate for the problem presented in Appendix 1.A. The only noteworthy complication is the necessity to invert untabulated transforms. Because of the lengthy, tedious algebraic manipulations involved, I give here only enough detail for interested readers to be able to reproduce my results.

The solutions for $\tilde{\theta}^{(0)}$ and $\tilde{\theta}^{(1)}$, the Laplace transforms of $\theta^{(0)}$ and $\theta^{(1)}$, respectively, are easily found to be

$$
\tilde{\theta}^{(0)}=\frac{1}{s}-\frac{\gamma}{s(s+\gamma)}\left(\frac{\cosh s^{1 / 2} \eta}{\cosh s^{1 / 2}}\right)
$$

and

$$
\begin{gathered}
\tilde{\theta}^{(1)}=\frac{1}{s^{1 / 2}}\left(\frac{\gamma}{\gamma+s}\right) \tanh s^{1 / 2} \\
\left.x \frac{\cosh \left[\left(s+4 \pi^{2} \mu^{2}\right)^{1 / 2} Y\right]}{\cosh \left[\left(s+4 \pi^{2} \mu^{2}\right)^{1 / 2}\right]}\right]_{\sin 2 \pi X},
\end{gathered}
$$

where $s$ is the transform variable corresponding to $\tau$. Neither transform is customarily tabulated, so I inverted by means of contour integrals in the complex plane (Levinson and Redheffer, 1970). To find $\theta^{(0)}$ and its derivatives with respect to $Y$, note that $\widetilde{\theta}^{(0)}$ has poles at $s=0, s=-\gamma$, and $s=s_{n}=-[\pi(2 n+1) / 2]^{2}(n=0,1,2,3 \ldots)$. To find $\theta^{(1)}$ and its derivatives with respect to $Y$, note that in addition to poles at $s=-\gamma, s=s_{n}$, and $s=s_{n}-4 \pi^{2} \mu^{2}(n=0,1,2,3 \ldots)$, a branch cut along the positive real axis from $s=0$ to $s=\infty$ is required so that $\tilde{\theta}^{(1)}$ be single-valued. The inversion integral must then wrap around the branch point at $s=0$. When evaluating $\partial \theta^{(1)} / \partial Y$ and thence the heat flux, the contribution from this part of the contour is non-zero and in fact is the critical contribution. Calculation of the result given by equation 1.A42 is facilitated by the fact that for a function $f(\tau)$, the Laplace transform of the integral

$$
\int_{0}^{\tau} f(t) d t
$$

is simply given by $\tilde{f}(s) / s$. 